ISSN: 2617-409X

\title{
APMN
}

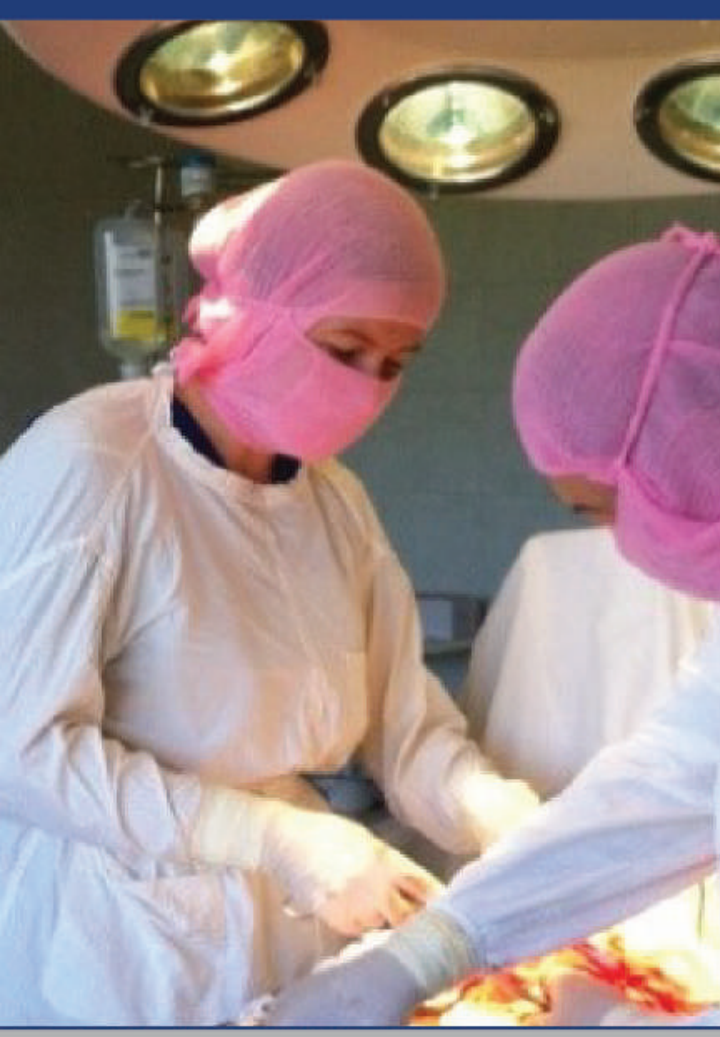

KARAZIN UNIVERSITY CLASSICS AHEAD OF TIME

$6 ` 2020$ ACTUAL PROBLEMS OF MODERN MEDICINE 
МIНICТЕРСТВО ОСВІТИ І НАУКИ УКРАЇНИ

ХАРКІВСЬКИЙ НАЦІОНАЛЬНИЙ УНІВЕРСИТЕТ іМЕН В. Н. КАРАЗІНА

MINISTRY OF EDUCATION AND SCIENCE OF UKRAINE

V. N. KARAZIN KHARKIV NATIONAL UNIVERSITY

\title{
Актуальні проблеми сучасної медицини
}

\section{Actual problems of modern medicine}

\author{
Випуск 6 \\ Issue 6 \\ Започатковане 2017 p. \\ електронне видання \\ electronic edition
}

Харків 2020 
The journal is a professional in the field of sciences in Ukraine, category «Б», 22 Health care, Specialties 222 Medicine, 224 Technologies of Medical Diagnosis and Treatment, 228 Pediatrics, 229 Public Health.

MES Ukraine Order № 1471 of 26.11.2020.

Approved for publication by the Academic Council of V. N. Karazin KhNU (protocol № 18 from 28.12.2020).

EDITOR-IN-CHIEF: Belozorov I. V., MD, PhD, Full Prof., V. N. Karazin KhNU.

\section{EDITORIAL COUNCIL}

Deputy Editor-in-chief: Tsivenko O. I., MD, PhD, Full Prof., V. N. Karazin KhNU.

Technical editors:

Matvieienko M. S., MD, V. N. Karazin KhNU.

Holubnycha H. I., MD, V. N. Karazin KhNU.

Shevchenko O. O., MD, PhD, Assoc. Prof., V. N. Karazin KhNU.

Shamoun E. K., MD, PhD, Assoc. Prof., V. N. Karazin KhNU.

\section{EDITORIAL BOARD}

Avdosyev $Y u$. V., MD, PhD, Full Prof. SI «V.T. Zaitsev Institute of General and Emergency Surgery of NAMS of Ukraine». Vasylyev D. V., MD, PhD, Assoc. Prof., V. N. Karazin KhNU. Gryshchenko M. G., MD, PhD, Full Prof., V. N. Karazin KhNU. Danylenko G. M., MD, PhD, Full Prof., State Enterprise "Institute for the Protection of Children and Adolescent Health of the National Academy of Medical Sciences of Ukraine. Kolesnichenko V, A., MD, PhD, Full Prof. V. N. Karazin KhNU. Kudrevych O. V., MD, PhD, Assoc. Prof., V. N. Karazin KhNU.

Makarov V. V., MD, PhD, Full Prof., KhNMU.

Martynenko O. V., PhD, Full Prof., V. N. Karazin KhNU.

Raimondi G., MD, PhD, Full Prof., Sapienza University of Rome (Italy).

Sotnikova-Meleshkina Zh. V., MD, PhD, Assoc. Prof., V. N. Karazin KhNU.

Nikolenko E. Ya., MD, PhD, Full Prof., V. N. Karazin KhNU.

Pastor H., MD, PhD, Full Prof., University of Barcelona (Spain).

Popov M. M., MD, PhD, Full Prof., V. N. Karazin KhNU. Protsenko O. S., MD, PhD, Full Prof., V. N. Karazin KhNU. Tykhonova T. M., MD, PhD, Prof., V. N. Karazin KhNU. Chernuskyi V. H., MD, PhD, Full Prof., V. N. Karazin KhNU. Fedotova I. F., MD, PhD, Prof., Sytenko Institute of Spine and Joint Pathology National Academy of Medical Sciences of Ukraine.

Khvorostov E. D., MD, PhD, Full Prof., V. N. Karazin KhNU. Shevchenko N. S., MD, PhD, Full Prof., V. N. Karazin KhNU. Shevchenko R. S., MD, PhD, Full Prof., KhNMU.

Sherstyuk S. O., MD, PhD, Full Prof., V. N. Karazin KhNU.

Editorial office:

V. N. Karazin Kharkiv National University School of

Medicine.

Svobody sq., 6, Kharkiv, Ukraine, 61022

Phone: +38 (057) 702-04-55

E-mail: apmm.meddep@karazin.ua

Web-page: http://periodicals.karazin.ua/apmm (Open Journal System)

Published articles have been double-blind reviewing.

(c) V. N. Karazin Kharkiv National University, publishing, design, 2020
Наукове фахове видання України, категорії «Б», галузь знань: 22 Охорона здоров'я, спеціальність: 222 Медицина, 224 Технології медичної діагностики та лікування, 228 Педіатрія, 229 Громадське здоров'я. Наказ МОН України № 1471 від 26.11.2020.

Затверджено до друку рішенням Вченої ради ХНУ імені В. Н. Каразіна (протокол № 18 від 28.12.2020 р).

ГОЛОВНИЙ РЕДАКТОР: Белозьоров І. В., д. мед. н., проф., ХНУ імені В. Н. Каразіна.

\section{РЕДАКЦІЙНА РАДА}

Заступник головного редактора: Цівенко О. І., д. мед. н., проф., ХНУ імені В. Н. Каразіна.

Технічні редактори:

Матвєєнко М. С., ХНУ імені В. Н. Каразіна.

Голубнича Г. І., ХНУ імені В. Н. Каразіна.

Шевченко О. О., к. мед. Н., доц., ХНУ імені В. Н. Каразіна. Шамун К. Є., к. мед. н., доц., ХНУ імені В. Н. Каразіна.

\section{РЕДАКЦІЙНА КОЛЕГІЯ}

Авдосьєв Ю. В., д. мед. Н., проф., ДУ «ІЗНХ імені В.Т. Зайцева НАМНУ»

Васильєв Д. В., к. мед. Н., доц., ХНУ імені В. Н. Каразіна. Грищенко М. Г., д. мед. н., проф., ХНУ імені В. Н. Каразіна. Даниленко Г. М., д. мед. н., проф., ДУ «Інститут охорони здоров'я дітей та підлітків НАМН України».

Колесніченко B. $\quad$ A., Д. мед. н., проф., ХНУ імені В. Н. Каразіна.

Кудревич О. М., к. мед. н., доц., ХНУ імені В. Н. Каразіна. Макаров В. В., д. мед. н., проф., ХНМУ.

Мартиненко О. В., д. фіз-мат. Н., проф., ХНУ імені В. Н. Каразіна.

Раймонди Ж., д. мед. н., проф., Римський університет Ла Сапієнца (Італія).

Сотнікова-Мелешкіна Ж. В., к. мед. н., доцент, ХНУ імені В. Н. Каразіна.

Ніколенко С. Я., д. мед. н., проф., ХНУ імені В. Н. Каразіна. Пастор X., д. мед. н., професор, Університет Барселони (Іспанія).

Попов М. М., д. мед. н., проф., ХНУ імені В. Н. Каразіна.

Проценко О. С., д. мед. Н., проф., ХНУ імені В. Н. Каразіна. Тихонова Т. М., д. мед. н., проф., ХНУ імені В. Н. Каразіна. Чернуський В. Г., д. мед. Н., проф., ХНУ імені В. Н. Каразіна.

Федотова I. Ф., д. мед. н., проф., ДУ "Інститут патології хребта та суглобів ім. М. І. Ситенка НАМНУ";

Хворостов С. Д., д. мед. н., проф., ХНУ імені В. Н. Каразіна. Шевченко Н. С., д. мед. н., проф., ХНУ імені В. Н. Каразіна. Шевченко Р. С., д. мед. н., проф., ХНМУ.

Шерстюк С. О., д. мед. н., проф., ХНУ імені В. Н. Каразіна.

\section{Адреса редакційної колегії:}

Харківський Національний Університет імені В. Н. Каразіна, Медичний факультет.

майдан Свободи, 6. Харків, Україна, 61022

Тел.: +38 (057) 702-04-55

E-mail: apmm.meddep@karazin.ua

Web-page: http://periodicals.karazin.ua/apmm (Open Journal System)

Статті пройшли двойне сліпе рецензування. 
3MICT

ОРИГІНАЛЬНІ ДОСЛІДЖЕННЯ

Гріднєва С. В., Резніченко О. Г., Мартиненко М. B.

Синдром подразненого кишечника 3 закрепами: питання патогенезу, діагностики та лікування

\section{CONTENTS}

\section{ORIGINAL RESEARCHES}

Gridnieva Svitlana, Reznichenko Oleksandr, Martynenko Maksym

Irritable bowel syndrome with constipation:

issues of pathogenesis, diagnostics and treatment

Лядова Т. І., Волобуєва О. В., Нартов П.В., Liadova Tetiana, Volobuieva Olha, Nartov Маланчук С. Г., Гололобова О. В., Козлов О. П., Pavlo, Malanchuk Svitlana, Hololobova Касьян Н. В., Гаміловска А. П., Шандер Т. А.

Клінічна ефективність кларитроміцину-МБ Olesia, Kozlov Oleksandr, Kasian Natalia, Gamilovska Alla, Shander Tetiana

в комплексній терапії хворих на негоспітальну пневмонію

Clinical efficiency of clarithromycin-MB in complex therapy of patients with non-hospital pneumonia

Ніколенко С. Я., Адамович І. В., Вовк К. В.

Nikolenko Evgene, Adamovych Iryna, Vovk Kira

Phenomenon of Text neck in higher вищих навчальних закладів education students

Панько Н. О., Лебець I. С., Шевченко Н. C., Panko Nataliya, Lebets Iryna, Shevchenko Цюра О. М., Шлєєнкова Г. О., Бутенко A. I. $\quad$ Natala, Tsiura Oksana, Shlieienkova Hanna, Клінічні особливості реактивних артритів у дітей Butenko Antonina

Clinical features of reactive arthritis in children

Попов М. М., Оленич В. Б., Лядова Т. І., Соловйова А. Г., Огнівенко О. В.

Хімічна характеристика біомембран гранулоцитів периферичної крові у часто хворих дітей із синдромом вегетативних дисфункцій

Popov Mykola, Olenych Vera, Liadova Tetiana, Ognivenko Olena, Soloviova Angelina

Chemical characteristics of peripheral blood granulocyte biomembranes in frequently ill children with autonomic dysfunction syndrome 
Чернитова I. М., Луценко О. B., Chernyshova Iryna, Lutsenko Olena, Данильчук А. В., Логвін Г. Б.

Danylchuk Alla, Logvin Galina

Систематизація заходів фізичної реабілітації дітей зі спадковими нервово-м'язовими захворюваннями

Systematization of methods of physical rehabilitation of children with inherited nervo-muscle diseases

Шерстюк С. О., Полстяной А. О., Прохорчук Р. М.

Sergey Sherstyuk, Andrii Polstyanoi, Roksolana Prokhorchuk

Непостійні кістки на черепах з скіфського могильника біля с. Коломак

Inconstant bones of the human skulls from scythians grave field near Kolomak village

\section{ОГЛЯДОВІ СТАТТІ}

\section{OBJECTIVE ARTICLE}

Березуцький В. І., Березуиька М. С.

Berezutsky Vladimir, Berezutska Maryna

«Переграна рука» або синдроми Overuse injuries in musicians. Part II: 74 перенапруги у музикантів. Частина II: prevention and treatment профілактика і лікування

Кирилова О. О., Кирилова Є. I., Kyrylova Olena, Kyrylova Yevheniia, Вострокнутов I. Л. Vostroknutov Ivan

Особливості соматопсихічних проявів в Features of somatopsychic manifestations in онкології на різних етапах протипухлинного лікування (оглядова стаття) oncology at different stages of anti-cancer therapy (review article)

Проченко О. С., Шаповал О. $\quad$ B., Protsenko Olena, Shapoval Olena, Teslenko Тесленко А. А., Ворона Д. А. Anna, Vorona Dariya

Розвиток та будова структур серцевосудинної системи: теоретичні та практичні аспекти вивчення. (Частина 1)

Development and organization of the cardiovascular system structures: theoretical and practical aspects of the study (Part 1) 


\title{
ОРИГІНАЛЬНІ ДОСЛІДЖЕННЯ
}

\section{IRRITABLE BOWEL SYNDROME WITH CONSTIPATION: ISSUES OF PATHOGENESIS, DIAGNOSTICS AND TREATMENT}

\author{
Gridnieva Svitlana, Reznichenko Oleksandr, Martynenko Maksym
}

Mail for correspondence: s.gridneva@karazin.ua

\begin{abstract}
Summary: Issues related to the diagnosis and treatment of irritable bowel syndrome occupy one of the central places in gastroenterology, due to the fact that in recent years there has been a significant increase in the incidence of this syndrome, its long-term recurrent, often lifelong course, leading to a decrease in the performance of patients, despite good quality, and a significant cost to the health care system. Irritable bowel syndrome, despite its functional nature, occurs quite often - from 14-50\% of the adult population according to population epidemiological studies, and the ratio of women to men is from 2: 1 to 4:1. In the structure of gastroenterological pathology, this disease accounts for 40-70\% of all cases of seeking medical help. Irritable bowel syndrome is a complex of functional disorders of the distal intestines, lasting more than 3 months and accompanied by abdominal pain that disappears after a bowel movement, flatulence, a feeling of incomplete bowel movement, changes in the frequency and consistency of stools. Factors in the pathogenesis of irritable bowel syndrome are dysfunction of mental activity with changes in autonomic and humoral functions; visceral hypersensitivity and impaired intestinal motility, past intestinal infection; endocrine disorders; food allergies, sedentary lifestyle; genetic predisposition. Endothelial dysfunction has recently played an important role in the onset of irritable bowel syndrome. The most famous among the factors of vascular endothelium today are the powerful vasoconstrictor endothelin-1 and the vasodilator - nitric oxide. The study investigated the level of vasoconstrictor endothelin-1 and vasodilator of nitric oxide in patients with irritable bowel syndrome with constipation. It was found that such patients have severe endothelial dysfunction, which manifests itself in an increase in the level of endothelin-1 ( $p<0,01)$, a decrease in the level of nitric oxide $(p<0,01)$. The data obtained indicate the role of dysfunction of the vascular endothelium in the pathogenesis of irritable bowel syndrome with constipation. An inverse correlation was found between the content of endothelin-1 and nitric oxide $(p<0.01)$, which indicates an increase in the activity of vasoconstrictor mechanisms with a simultaneous decrease in vasodilation factors. The effectiveness of complex therapy in the group of patients in whom folic acid and zincteral were used as part of complex therapy in improving the clinical picture of the disease (complete relief of dyspeptic syndrome and a significant decrease in the severity of pain, constipation and asthenic syndromes), restoration of vascular endothelial function (significant decrease in the level of endothelin-1 and an increase in the level of nitric oxide) in comparison with the group of patients in the treatment of which only basic therapy was used.
\end{abstract}

Key words: irritable bowel syndrome, constipation, endothelin -1, nitric oxide, endothelial dysfunction

Information about author

Gridnieva Svitlana, $M D, P h D$, Assoc.

Prof. of Department of General Practice -

Family Medicine, School of Medicine,

N.V. Karazin Kharkiv National University,

Svobody sq., 6, Kharkiv, Ukraine, 61022

e-mail: s.gridneva@karazin.ua

https://orcid.org/0000-0002-7498-9574
Reznichenko Oleksandr, MD, PhD, Assoc. Prof. of Department of General Practice - Family Medicine, School of Medicine, N.V. Karazin Kharkiv National University, Svobody sq., 6, Kharkiv,

Ukraine, 61022

e-mail: ax.reko@ rambler.ru

https://orcid.org/0000-0001-8189-7048
Martynenko Maksym, Assistant of Department of General Practice - Family Medicine, School of Medicine, N.V. Karazin Kharkiv National University, Svobody sq., 6, Kharkiv, Ukraine, 61022 e-mail: maksim200282@gmail.com https://orcid.org/0000-0003-2894-4348
Introduction. Irritable bowel syndrome (IBS) is defined as an independent nosological disease of the intestine, which is manifested by a number of functional motor-secretory disorders of the intestine of an inorganic nature: mental dysfunction, impaired intestinal motility, immune function of the intestine, visceral hyperalgesia and a change in intestinal microbiome [1].
The leading factors in the pathogenesis of IBS is a violation of the function of mental activity with a change in vegetative and humoral functions. Patients with IBS have a higher level of anxiety and depressive disorders, sleep disturbances than in healthy individuals. In such patients, increased excitability of neurons of the posterior horns of the spinal cord is noted. In this area, a high content of catecholamines and serotonin is noted, in the future afferent signals 
entering the brain are amplified. Activation of 5HT3 receptors of enterochromaffin cells with catecholamines and increased production of serotonin leads to an increase in intracellular calcium, which causes an increase in pain with stimulation of peristalsis and the development of visceral hypersensitivity $[2,3]$.

Visceral hyperalgesia (hypersensitivity to mechanical, thermal, chemical and other peripheral stimuli) is an important cause of abdominal pain in IBS, as well as motor and secretory disorders that occur in response to subthreshold stimuli (allodynia). Psycho-social stress, chronic physical overload, intestinal infections, heredity are form visceral hypersensitivity. [1, 2, 4].

Motility disorders in IBS are manifested by spastic and hypermotor dyskinesia. With spastic dyskinesia, there is a slowdown in the transit of chyme along the colon, which leads to constipation. With this type of dysmotoric, there is an increase in water absorption by the intestine with a decrease in the volume of feces and an increase in their density. With hypermotor dyskinesia, there is an acceleration of the transit of intestinal chyme with the development of diarrhea [1-3].

The constituents of the intestinal microflora have different effects on intestinal motility. Thus, short-chain fatty acids produced by the intestinal microbiota stimulate enterochromaffin cell receptors, thus contributing to an increase in the production of serotonin, activation of sensitive neurons in the submucosal layer of the intestine and increase its contraction. In contrast, nitric oxide, which is synthesized by propionobacteria, and a vasointestinal peptide affect neuromuscular synapses, followed by relaxation of the intestinal wall $[1,2,5]$.

The occurrence of IBS as a multifactorial disease is also promoted by: past intestinal infection; endocrine disorders (dysmenorrhea, menopause, diabetes, hypothyroidism, obesity); disaccharidase deficiency, especially hypolactasia; food allergies and intolerances to certain foods; sedentary lifestyle; widespread use of drugs (antibiotics, antacids, betablockers); genetic predisposition [1-3].

A certain role in the occurrence of IBS is given to endothelial dysfunction. The vascular endothelium is involved in many physiological and pathophysiological processes in the human organism, produces and releases into the bloodstream and subendothelial space biologically active substances that regulate vascular tone, growth processes, affect the state of smooth muscle cells, circulating blood elements, and fibroblast proliferation. One of the most famous among these substances today is the powerful vasoconstrictor endothelin - 1 $(\mathrm{ET}-1)$ and the vasodilator - nitric oxide (NO) [6-9].

It was established that with IBS there is an increased level of ET-1 and vascular endothelial growth factor in blood plasma. The maximum increase in ET-1 and vascular endothelial growth factor was found in patients with IBS with constipation, with a painful form - the indicators were slightly lower, in patients with diarrhea the increase in ET-1 was minimal $[9,10]$.

The role of another vasoactive peptide with the property of vasodilation, nitric oxide, is also being investigated in the pathogenesis of IBS. NO helps to relax the smooth muscles of the small and large intestines, the anal sphincter with the help of the neurogenic NOS (NOsynthase) contained in nitrergic neurons. NOS content was detected in Auerbach plexus neurons, in the adventitia of the gastrointestinal vessels [11].

Mucosal processes in the intestinal epithelium are associated with NO. NO improves microcirculation in mesenteric vessels and helps maintain intestinal mucosa integrity. With IBS, there is a reduced level of NO both in the blood and in the mucous membrane of the colon, with a more pronounced decrease in NO in the blood than in the tissues. A decrease in NOS activity was revealed when it was examined in the blood and colon mucosa in IBS, and a direct correlation was found between the level of NO in the blood and in the colon mucosa $[11,12]$.

NO plays an important role in the processes of regulation of motility (increased tone of the intestines and sphincters with its deficiency), secretion (stimulation of such), in the protection of the gastrointestinal mucosa (damage with NO deficiency), microcirculation (vasoconstriction and thrombosis with NO deficiency) [12].

Further study of the function of the vascular endothelium is undoubtedly relevant and has 
great scientific and practical importance, since endothelin - 1 and nitric oxide occupy a leading place in the pathogenesis of many conditions, including diseases of the gastrointestinal tract, namely irritable bowel syndrome. Many issues related to the participation of these substances in various physiological and pathophysiological mechanisms currently remain open and require further study, which will change the understanding of the development of many diseases, develop new methods for influencing the course of physiological and pathophysiological processes.

Particular attention is paid to therapeutic approaches aimed at restoring or maintaining the function of the vascular endothelium. Folic acid, as well as zincteral, which includes zinc, have a positive effect on endothelial function, along with other drugs. Zinc helps to eliminate damage to the mucous membranes of the digestive tract, the phenomena of intestinal dysbiosis, normalizes the microflora of the epithelial integument. Zinc and folic acid are essential elements for restoring the structure of damaged intestinal cells. [13-16].

Purpose of the study - study the level of Et 1 and nitric oxide in patients with IBS with constipation and to correct the revealed violations with zincteral and folic acid as part of complex therapy.

Materials and methods: 88 patients with IBS with constipation were examined: women $61(68.6 \%)$, men - $27(31.4 \%)$ aged 20 to 50 years. The control group included 18 healthy individuals. The diagnosis is verified. All patients, depending on the therapy taken, were divided into 2 groups: patients of the first group (59 patients) received standard folic acid (prokinetics, probiotics, laxatives) additionally folic acid at $0.001 \mathrm{~g} 3$ times a day and zincteral $0.124 \mathrm{~g} 3$ times per day for 3 weeks, patients of the second group (29 patients) received standard therapy.

Results and discussion: The clinical picture of the disease in patients of both groups was dominated by pain, constipation, asthenic and dyspeptic syndromes.
In the first group, pain syndrome was detected in 51 patients with IBS $(81.7 \pm 4.99 \%)$. An objective examination showed pain during palpation along the colon in 48 patients $(81.4 \pm 4.5 \%)$, constipation syndrome in all examined patients, asthenic syndrome in 44 $(76.3 \pm 5.4 \%)$, and dyspeptic in 36 patients $(54.1 \pm 6.1 \%)$.

After the treatment (21 days from the start of treatment) with a subjective examination, the pain syndrome disappeared in $40(64.1 \pm 6.7 \%)$ patients, decreased in intensity - in 13 $(18.1 \pm 5.5 \%)$; an objective examination: was absent in $29(47 \pm 6.36 \%)$, decreased in intensity - in $25(33.2 \pm 6.13 \%)$. Constipation syndrome disappeared in $53(83 \pm 4.35 \%)$ patients, and constipation persisted in 7 $(6.8 \pm 3.14 \%)$ patients. Asthenic syndrome was arrested in $46(71.6 \pm 5.35 \%)$ patients; weakness and irritability persisted in 4 patients $(3.18 \pm 2.48 \%)$. Dyspeptic syndrome was stopped in all patients in this group.

In the second group: pain was observed in 22 $(74.7 \pm 8.12 \%)$ patients. An objective examination showed pain in all patients. Constipation syndrome was observed in all patients, asthenic - in $13(46.4 \pm 9.17 \%)$, dyspeptic - in $8(33.6 \pm 9.46 \%)$.

After the treatment, the pain syndrome was stopped in $12(51 \pm 11.8 \%)$ patients, in 10 $(48 \pm 11.3 \%)$ it decreased in intensity. The abdomen on palpation in $6(19.43 \pm 8.64 \%)$ patients became painless, in $16(82.4 \pm 8.42 \%)$ during palpation along the colon, the pain decreased in intensity. Constipation syndrome was arrested in $8(35.6 \pm 10.13 \%)$ patients, and persisted in $14(64.7 \pm 10.13 \%)$ patients. Asthenic syndrome disappeared in 10 $(67.3 \pm 11.8 \%)$ patients, and in $3(30.1 \pm 16.3 \%)$ patients, the general disturbance of health remained.

When analyzing the clinical picture of the disease of patients with IBS with constipation in the dynamics of treatment, one can note a significant improvement in subjective and objective clinical symptoms in the first group of patients who received folic acid and zincteral in addition to standard therapy in comparison with patients of the second group who received standard therapy (Fig. 1). 


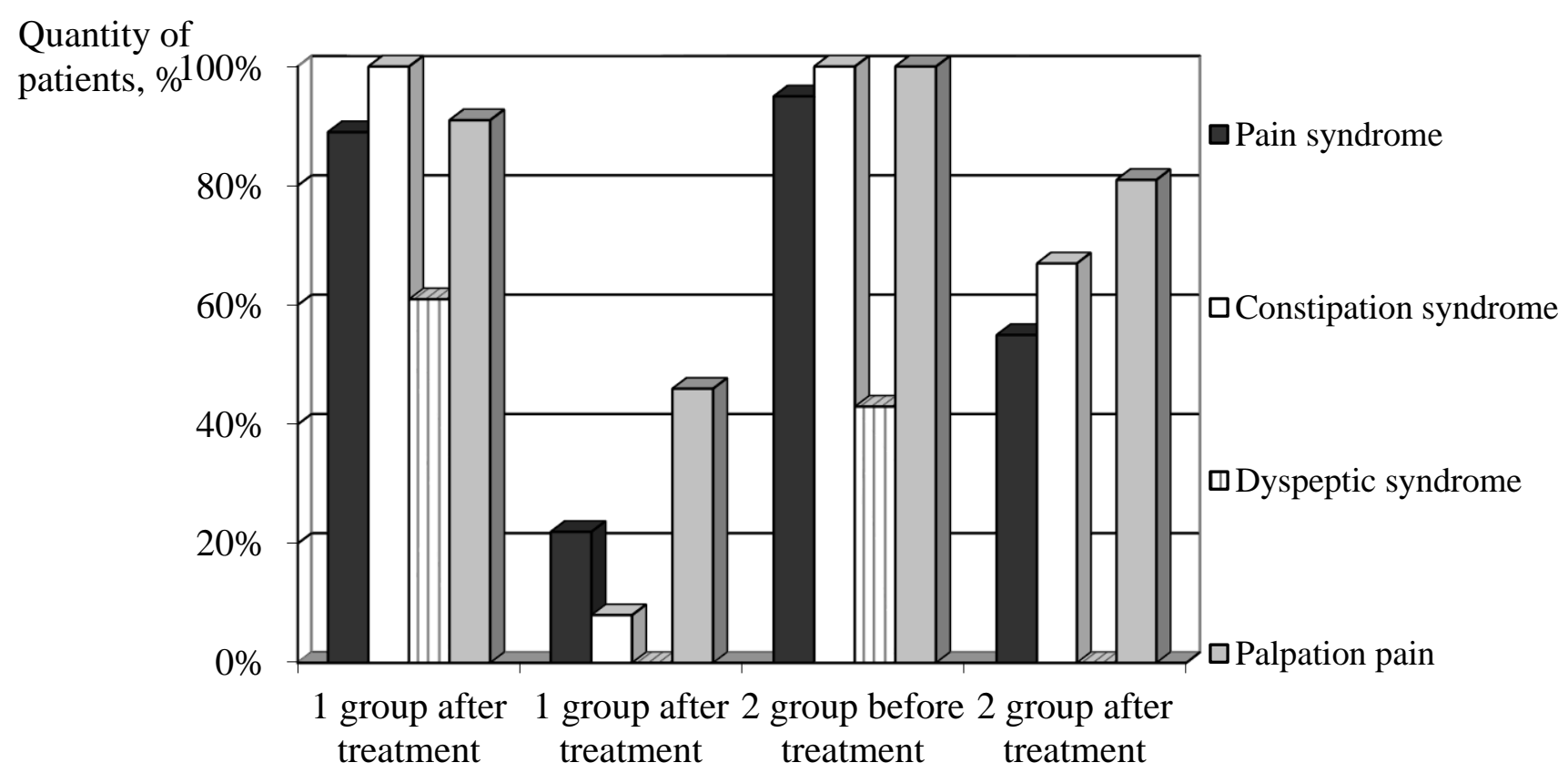

Fig.1. The dynamics of clinical manifestations in the examined patients before and after treatment

When studying endothelial function in patients with IBS with constipation, a level of Et - 1 was significantly increased, compared with the control group, and NO was significantly reduced, compared with the control group. Data on the content of Et - 1 and NO in the blood of patients with IBS with constipation and persons of the control group are presented in table.

Table 1. The content of Et -1 and NO in the blood of patients with IBS with constipation and in the control group

\begin{tabular}{|c|c|c|}
\hline Groups & $\begin{array}{c}\mathrm{Et}-1 / \mathrm{pmol} / \mathrm{l}, \\
\mathrm{M} \pm \mathrm{m}\end{array}$ & $\begin{array}{c}\mathrm{NO} / \mathrm{mg} / \mathrm{l}, \\
\mathrm{M} \pm \mathrm{m}\end{array}$ \\
\hline $\begin{array}{c}\text { Patients with } \\
\text { IBS with } \\
\text { constipation }\end{array}$ & $4,64 \pm 0,26$ & $1,67 \pm 0,04$ \\
\hline Control group & $1,85 \pm 0,15$ & $2,38 \pm 0,06$ \\
\hline $\mathrm{p}$ & $\mathrm{p}<0,01$ & $\mathrm{p}<0,01$ \\
\hline
\end{tabular}

Note: $\mathrm{p}$ - when comparing indicators Et - 1 and NO in patients with IBS with constipation with indicators Et - 1 and NO in individuals of the control group

An inverse correlation was found between the content of Et -1 and NO $(r=-0.63)(p<0.01)$, that is, with an increase in the activity of vasoconstrictor mechanisms, a decrease in vasodilation factors is noted.
Et - 1 causes a reduction in the smooth muscles of the colon in experimental animals, and insufficient formation of NO, in turn, contributes to impaired gastrointestinal motility. In this regard, it can be assumed that a reduced level of $\mathrm{NO}$, along with an increased level of Et -1 in patients with IBS with constipation, are the mechanisms that lead to the development of intestinal dysmotoria with spastic phenomena and the development of constipation syndrome $[12,17]$.

All patients, depending on the therapy taken, were divided into 2 groups: patients of the first group (59 patients) received standard therapy (prokinetics, probiotics, laxatives) and additionally folic acid at $0.001 \mathrm{~g} 3$ times a day and zincteral $0.124 \mathrm{~g} 3$ times per day for 3 weeks, patients of the second group (29 patients) received standard therapy.

During treatment, patients of the first group showed a significant decrease, compared with the group before treatment, of the level of Et - 1, which contributed to an improvement in the functional state of the vascular endothelium, a decrease in spasm of the smooth muscles of the colon and an improvement in intestinal motility.

Data on the content of Et - 1 in blood plasma in patients of the first and second groups in the dynamics of treatment are presented in table 2 . 
Table 2. The content of ET-1 in blood plasma in patients of the first and second groups before and after treatment

\begin{tabular}{|l|c|c|}
\hline \multicolumn{1}{|c|}{ Groups } & $\begin{array}{c}\text { ET-1 - 1 before } \\
\text { treatment, } \mathrm{M} \pm \mathrm{m}\end{array}$ & $\begin{array}{c}\text { ET-1 - } 1 \text { before } \\
\text { treatment, } \mathrm{M} \pm \mathrm{m}\end{array}$ \\
\hline First group & $4,64 \pm 0,26 \mathrm{pmol} / \mathrm{l}$ & $2,1 \pm 0,2 \mathrm{pmol} / \mathrm{l} *$ \\
\hline $\begin{array}{l}\text { Second } \\
\text { group }\end{array}$ & $4,64 \pm 0,26 \mathrm{pmol} / \mathrm{l}$ & $\begin{array}{c}4,2 \pm 0,3 \mathrm{pmol} / \mathrm{l} \\
* *\end{array}$ \\
\hline $\begin{array}{l}\text { Control } \\
\text { group }\end{array}$ & \multicolumn{2}{|c|}{$1,85 \pm 0,15 \mathrm{pmol} / \mathrm{l}$} \\
\hline
\end{tabular}

Note: $* \mathrm{p}<0.001-$ when comparing the indicators Et -1 of the first group with the group before treatment.

$* * \mathrm{p}<0.05$ - when comparing the indicators Et - 1 of the second group with the group before treatment.

In patients of the second group, during the treatment process, a decrease in the level of Et - 1 was not statistically possible $(\mathrm{p}<0.05)$, compared with the group before treatment. A significant difference $(\mathrm{p}<0.01)$ was noted when comparing the Et - 1 indices of the first and second groups after treatment.

In the study of the level of NO in patients of the first group in the dynamics of treatment, a possible increase was noted in comparison with the group before treatment, which helped to reduce spastic phenomena of smooth intestinal muscles.

Data on the content of $\mathrm{NO}$ in blood serum in patients of the first and second groups before and after treatment are presented in table 3 .

Table 3. The content of NO in the blood serum of patients of the first and second groups in the dynamics of treatment

\begin{tabular}{|c|c|c|}
\hline Groups & $\begin{array}{c}\text { NO before } \\
\text { treatment, } \mathrm{M} \pm \mathrm{m}\end{array}$ & $\begin{array}{c}\mathrm{NO} \text { after } \\
\text { treatment, } \mathrm{M} \pm \mathrm{m}\end{array}$ \\
\hline First group & $1,67 \pm 0,04 \mathrm{mg} / \mathrm{l}$ & $2,24 \pm 0,08 \mathrm{mg} / \mathrm{l} *$ \\
\hline $\begin{array}{c}\text { Second } \\
\text { group }\end{array}$ & $1,67 \pm 0,04 \mathrm{mg} / \mathrm{l}$ & $\begin{array}{c}1,83 \pm 0,03 \mathrm{mg} / \mathrm{l} \\
* *\end{array}$ \\
\hline $\begin{array}{c}\text { Control } \\
\text { group }\end{array}$ & \multicolumn{2}{|c|}{$2,38 \pm 0,06 \mathrm{мг} / \mathrm{л}$} \\
\hline
\end{tabular}

Note: $* \mathrm{p}<0.001$ - when comparing the NO indicators of the first group with the group before treatment

** $\mathrm{p}<0.05$ - when comparing the NO indicators of the second group with the group before treatment

In patients of the second group who received standard therapy, an increase in the level of NO was noted, however, its value was not statistically significant $(\mathrm{p}<0.05)$, compared with the group before treatment.
Conclusions: 1 . In patients with irritable bowel syndrome with constipation, there is a violation of the function of the vascular endothelium in the form of an increased level of endothelin - 1 and a reduced level of nitric oxide in the blood.

2. An inverse correlation was found between the content of Et -1 and NO ( $r=-0.63)(p<0.01)$, that is, with an increase in the activity of vasoconstrictor mechanisms, a decrease in vasodilation factors is noted.

3. The inclusion in the complex therapy of patients with IBS with constipation of folic acid and zincteral contributes to the positive dynamics of the clinical picture of the disease, the optimal restoration of endothelial function in comparison with standard therapy.

\section{Список літератури}

1. Звягинцева ТД, Гриднева СВ. Новые концепции развития синдрома раздраженного кишечника и подходы к лечению. Новости медицины и фармации. (Гастроэнтерология). 2016;(577):8-12.

2. Звягинцева ТД, Гриднева СВ. Синдром раздраженного кишечника: современные представления и новые возможности коррекции. Східнєвропейський журнал внутрішньої та сімейної медицини. 2018;(2):4-9. 3. Фадеенко ГД., Гриднев АЕ. Синдром раздраженного кишечника и кишечный микробиом. От патогенетических механизмов к лечению. Новини медицини та фармації. Журнал Гастроентерология.. 2018;52(4):8-9.

4. Шептулин АА, Визе-Хрипунова МА. Новое в этиологии и патогенезе синдрома раздраженного кишечника. Клиническая медицина. 2016;94(2):92-96. DOI: 10.18821/0023-2149-2016-94-2-92-96

5. Янковский ДС., Широбоков ВП., Дымент ГС, Микробиом. 2017.640 с. DOI: 10.11603/16812727.2018.3.9427

6. Cibor D., Domagala-Rodacka R. et al. Endothelial dysfunction in inflammatory bowel diseases: Pathogenesis, assessment and implications. World J Gastroenterol. 2016 Jan 21;22(3):1067-1077. DOI:10.3748/wjg.v22.i3.1067

7. Frederik C. Enevoldsen, Jayashree Sahana et al. Endothelin Receptor Antagonists: Status Quo and Future Perspectives for Targeted Therapy. J Clin Med. 2020 Mar;9(3):824. DOI:10.3390/jcm9030824

8. Houde M., Desbiens L., D'Orléans-Juste P. Endothelin-1: Biosynthesis, Signaling and Vasoreactivity. Adv. Pharmacol. 2016;77:143-75. $\quad$ DOI: 10.1016/bs.apha.2016.05.002

9. Lankhorst S., Danser A.H. et al. Endothelin-1 and antiangiogenesis. Am. J. Physiol. Regul. Integr. Comp. Physiol. 2016 Feb 01;310(3):230-4. DOI: 10.1152/ajpregu.00373.2015

10. Han W., Guo C. et al. Role of endothelin and nitric oxide in the pathogenesis of irritable bowel syndrome. Chinese Journal of Gastroenterology. 2002;7(6):342-344 
11. Zhao Y., Vanhoutte PM. et al. Vascular nitric oxide: Beyond eNOS. J. Pharmacol. Sci. 2015 Oct;129(2):83-94. DOI:10.1016/j.jphs.2015.09.002.

12. Muscara M., Wallace J. Therapeutic potential of nitric oxide donors and inhibitors. Am. J. Physiol. 1999;276:G1313-1316

DOI:

10.1152/ajpgi.1999.276.6.G1313

13. Sal'nikova Ye.V. Potrebnost' cheloveka v tsinke i yego istochniki. Mikroelementy v meditsine. 2016;17(4):11-15 (In Russ.).

14. Liping Huang, Victoria J. Drake et al. Zinc. Advances in Nutrition. 2015;6 (2):224-226 DOI: 10.3945/an.114.006874 15. Takafumi Hara, Taka-aki Takeda et al. Physiological roles of zinc transporters: molecular and genetic importance in zinc homeostasis. The Journal of Physiological Sciences. 2017;(67):283-301 DOI: 10.1007/s12576-017-0521-4.

16 Sung Ryul Lee. Critical Role of Zinc as Either an Antioxidant or a Prooxidant in Cellular Systems. Oxidative medicine and cellular longevity. 2018;(15):1-11 DOI: $10.1155 / 2018 / 9156285$

17.Sugimachi M., Kiyohara T., Murayama T. et al. Endogenous endothelin in a rat model of acute colonic mucosal injury. Gastroenterology and Hepatology. 2000;15(10):1125-1131 DOI:10.1046/j.14401746.2000.02311.x

\section{References:}

1. Zvyagintseva TD, Gridneva SV. Novyye kontseptsii razvitiya sindroma razdrazhennogo kishechnika i podkhody $\mathrm{k}$ lecheniyu. Novosti meditsiny i farmatsii. (Gastroyenterologíya). 2016;(577):8-12 (In Russ.).

2. Zvyagintseva TD, Gridneva SV. Sindrom razdrazhennogo kishechnika: sovremennyye predstavleniya i novyye vozmozhnosti korrektsii. Skhídnoêvropeys'kiy zhurnal vnutríshn'oï ta símeynoï meditsini. 2018;(2):4-9 (In Russ.).

3. Fadeyenko GD, Gridnev AYe. Sindrom razdrazhennogo kishechnika i kishechnyy mikrobiom. Ot patogeneticheskikh mekhanizmov k lecheniyu. Novini meditsini ta farmatsií. Zhurnal «Gastroenterologiya». 2018;52(4):8-9 (In Russ.).

4. Sheptulin AA, Vize-Khripunova MA. Novoye v etiologii i patogeneze sindroma razdrazhennogo kishechnika. Klinicheskaya meditsina. 2016; 94(2):92-96. (In Russ.). DOI: 10.18821/0023-2149-2016-94-2-92-96

5. Yankovskiy DS, Shirobokov VP, Dyment GS. Mikrobiom. 2017.640 p. (In Russ.). DOI: 10.11603/16812727.2018.3.9427
6. Cibor D, Domagala-Rodacka $\mathrm{R}$ et al. Endothelial dysfunction in inflammatory bowel diseases: Pathogenesis, assessment and implications. World J Gastroenterol. 2016 Jan 21;22(3):1067-1077. DOI:10.3748/wjg.v22.i3.1067

7. Frederik C. Enevoldsen, Jayashree Sahana et al. Endothelin Receptor Antagonists: Status Quo and Future Perspectives for Targeted Therapy. J Clin Med. 2020 Mar;9(3):824. DOI:10.3390/jcm9030824

8. Houde M, Desbiens L, D'Orléans-Juste P. Endothelin-1: Biosynthesis, Signaling and Vasoreactivity. Adv. Pharmacol. 2016;77:143-75. DOI: 10.1016/bs.apha.2016.05.002

9. Lankhorst S, Danser AH et al. Endothelin-1 and antiangiogenesis. Am. J. Physiol. Regul. Integr. Comp. Physiol. 2016 Feb 01;310(3):230-4. DOI: 10.1152/ajpregu.00373.2015

10. Han W, Guo C et al. Role of endothelin and nitric oxide in the pathogenesis of irritable bowel syndrome. Chinese Journal of Gastroenterology. 2002; 7(6):342-344

11. Zhao Y, Vanhoutte PM. et al. Vascular nitric oxide: Beyond eNOS. J. Pharmacol. Sci. 2015 Oct;129(2):83-94. DOI:10.1016/j.jphs.2015.09.002.

12. Muscara M, Wallace J. Therapeutic potential of nitric oxide donors and inhibitors. Am. Journal Physiol. 1999;276:G1313-1316

DOI:10.1152/ajpgi.1999.276.6.G1313

13. Sal'nikova YeV. Potrebnost' cheloveka v tsinke i yego istochniki. Mikroelementy v meditsine. 2016;17(4):11-15 (In Russ.).

14. Liping Huang, Victoria J. Drake et al. Zinc. Advances in Nutrition. 2015;6 (2):224-226 DOI: 10.3945/an.114.006874 15. Takafumi Hara, Taka-aki Takeda et al. Physiological roles of zinc transporters: molecular and genetic importance in zinc homeostasis. The Journal of Physiological Sciences. 2017;(67):283-301 DOI: 10.1007/s12576-017-0521-4.

16 Sung Ryul Lee. Critical Role of Zinc as Either an Antioxidant or a Prooxidant in Cellular Systems. Oxidative medicine and cellular longevity. 2018;(15):1-11 DOI: $10.1155 / 2018 / 9156285$

17. Sugimachi M, Kiyohara T, Murayama T. et al. Endogenous endothelin in a rat model of acute colonic mucosal injury. Gastroenterology and Hepatology. 2000;15(10):1125-1131 DOI:10.1046/j.1440-

1746.2000.02311.x

\title{
СИНДРОМ ПОДРАЗНЕНОГО КИШЕЧНИКА З ЗАКРЕПАМИ: ПИТАННЯ ПАТОГЕНЕЗУ, ДІАГНОСТИКИ ТА ЛІКУВАННЯ
}

\author{
Гріднєва С. В., Резніченко О. Г., Мартиненко М. В.
}

Пошта для листування: s.gridneva@karazin.ua

\begin{abstract}
Резюме: Питання, пов'язані з діагностикою та лікуванням синдрому подразненого кипечника є одним із центральних місиь в гастроентерології, в зв'язку з тим, що в останні роки відзначається значне зростання захворюваності даними синдромом, його тривалий рецидивний, часто довічний перебіг, щуо призводить до зниження пращездатності пацієнтів, незваэсаючи на доброякісний характер, і значних витрат системи охорони здоров'я. Синдром подразненого кишечника, незважсаючи на його функціональну природу, зустрічається досить часто - від 14 до 50\% дорослого населення за даними
\end{abstract}


популямійних епідеміологічних досліджень, а співвідномення жінок $і$ чоловіків - від 2:1 до 4:1. $У$ структурі гастроентерологічної патологї на ще захворювання припадає 40-70\% всіх випадків звернень по лікарську допомогу. В роботі досліджено рівень вазоконстриктору ендотеліну-1 i вазодилятатору оксиду азоту у хворих на синдром подразненого кимечника з запорами. Встановлено, що у таких памієнтів має місче вираюсена ендотеліальна дисфункиія, яка проявлятться в підвищенні рівня ендотеліну-1 (p<0,01), зниюсенні рівня оксиду азоту (p<0,01). Отримані дані свідчать про роль порушення функиіі судинного ендотелію в патогенезі синдрому подразненого кишечника з запорами. Виявлена зворотня кореляиійна залежність між вмістом ендотеліну - 1 та оксиду азоту (p<0,01), шуо свідчить про підвищення активності вазоконстрікторних механізмів з одночасним зниюсенням факторів вазодилятации. Відзначено ефективність комплексної терапї̈ в групі пачієнтів, у яких в складі комплексноїтерапії застосовувалася фолієва кислота i иуинтерал в поліпшенні клінічної картини захворювання (повне купірування диспептического синдрому $і$ значне зменшення по виразності больового, констіпаціонного і астенічного синдромів), відновленні функції ендотелію судин (достовірне знижения рівня ендотеліну-1 і підвищення рівня оксиду азоту) в порівнянні з групою хворих, в лікуванні яких застосовувалася тільки базисна терапія.

Ключові слова: синдром подразненого кишечника, закреп, ендотелін -1, оксид азоту, ендотеліальна дисфункція

\author{
Інформація про авторів \\ Гріднєва Світлана Вікторівна, доц. \\ кафедри загальної практики - сімейної \\ медицини медичного факультету \\ Харківського національного \\ університету імені В. Н. Каразіна, \\ майдан Свободи, 6, Харків, Україна, \\ 61022 \\ e-mail: s.gridneva@karazin.ua \\ https://orcid.org/0000-0002-7498-9574
}

\author{
Резніченко Олександр Георгійович, \\ доц. кафедри загальної практики - \\ сімейної медицини медичного \\ факультету Харківського національного \\ університету імені В. Н. Каразіна, \\ майдан Свободи, 6, Харків, Україна, \\ 61022 \\ e-mail: ax.reko@rambler.ru \\ https://orcid.org/0000-0001-8189-7048
}

\begin{abstract}
Мартиненко Максим Вікторович, асистент кафедри загальної практики сімейної медицини медичного факультету Харківського національного університету імені В. Н. Каразіна, майдан Свободи, 6, Харків, Україна 61022

e-mail: maksim200282@gmail.com https://orcid.org/0000-0003-2894-4348
\end{abstract}

\title{
СИНДРОМ РАЗДРАЖЕННОГО КИШЕЧНИКА С ЗАПОРАМИ: ВОПРОСЫ ПАТОГЕНЕЗА, ДИАГНОСТИКИ И ЛЕЧЕНИЯ
}

\author{
Гриднева С. В., Резниченко А. Г., Мартыненко М. В.
}

Пошта для листування: s.gridneva @ karazin.ua

Резюме. Вопросы, связанные с диагностикой и лечением синдрома раздраженного кишечника, занимают одно из изентральных мест в гастроэнтерологии, в связи с тем, что в последние годы отмечается значительный рост заболеваемости данным синдромом, его длительное рецидивное, часто пожизненное течение, приводящее к снижению работоспособности пацииентов, несмотря на доброкачественньй характер, и значительным затратам системы охраны здоровья. Синдром раздраженного кишечника, несмотря на его функичональную природу, встречается достаточно часто - от 14-50\% взрослого населения по данным популяционных эпидемиологических исследований, а соотношение женщин и мужчин - от 2:1 до 4:1. В структуре гастроэнтерологической патологии на это заболевание приходится 40-70\% всех случаев обращений за врачебной помощью. В работе исследован уровень вазоконстриктора эндотелина-1 и вазодилятатора оксида азота у больных синдромом раздраженного кишечника с запорами. Установлено, что у таких пациентов имеет место выраженная эндотелиальная дисфункция, которая проявляется в повышении уровня эндотелина-1 ( $<0,01)$, снижении уровня оксида азота $(p<0,01)$. Полученные данные свидетельствуют о роли нарушения функции сосудистого эндотелия в патогенезе синдрома раздраженного кишечника с запорами. Выявлена обратная корреляционная зависимость между содержанием эндотелина - 1 и оксида азота ( $<<0,01)$, что свидетельствует о повыпении активности вазоконстрикторных механизмов с одновременным снижением факторов вазодилятации. Отмечена эффективность комплексной терапии в группе пациентов, у которых в составе комплексной терапии применялась фолиевая кислота и ичинтерал в улучшении клинической картины заболевания (полное купирование диспептического синдрома и значительное уменьшение по выраженности болевого, констипацчионого и астенического синдромов), восстановлении функции эндотелия сосудов (достоверное снижение уровня эндотелина -1 и повышение уровня оксида азота) в сравнении с группой больных, в лечении которых применялась только базисная терапия. 
Ключевые слова: синдром раздраженного кишечника, запор, эндотелин -1, оксид азота, эндотелиальная дисфункция

\section{Информация об авторах}

Гриднева Светлана Викторовна, доц. кафедры общей практики - семейной медицины медицинского Харьковского факультета национального университета имени В. Н. Каразина, пл. Свободы, 6, Харьков, Украина, 61022 e-mail: s.gridneva@karazin.ua https://orcid.org/0000-0002-7498-9574
Резниченко Александр Георгиевич, доц. кафедры общей практики - семейной медицины медицинского факультета Харьковского национального университета имени В. Н. Каразина, пл Свободы, 6, Харьков, Украина, 61022 e-mail: ax.reko@rambler.ru https://orcid.org/0000-0001-8189-7048
Мартьлненко Максим Викторович, ассистент кафедры общей практики семейной медицины медицинского факультета Харьковского национального университета имени B. Н. Каразина, пл. Свободы, 6, Харьков, Украина, 61022 e-mail: maksim200282@gmail.com https://orcid.org/0000-0003-2894-4348

Conflicts of interest: author has no conflict of interest to declare.

Конфлікт інтересів: відсутній.

Конфликт интересов: отсутствует. 


\title{
CLINICAL EFFICIENCY OF CLARITHROMYCIN-MB IN COMPLEX THERAPY OF PATIENTS WITH NON-HOSPITAL PNEUMONIA
}

\author{
Liadova Tetiana, Volobuieva Olha, Nartov Pavlo, Malanchuk Svitlana, Hololobova Olesia, Kozlov \\ Oleksandr, Kasian Natalia, Gamilovska Alla, Shander Tetiana
}

Mail for correspondence: o.volobyeva@karazin.ua

Summary: The problem of rational antibiotic therapy of pneumonia is among the most relevant in modern medicine. The aim of the study was to evaluate the clinical efficacy and therapeutic tolerance of parenteral application of clarithromycin in the treatment of patients with non-hospital pneumonia (NHP). Materials and methods. We observed 20 patients: 12 men - (60\%), 8 women-(40\%), the average age of patients was $46.1 \pm 17.6$ years. All patients showed clinical symptoms of severe infection of the lower respiratory tract. In $75.0 \%$ (15 patients) bilateral lung damage was noted, in 27\% (5 patients) - unilateral lung tissue damage. Hemoptysis was observed in $4(20 \%)$ patients. Clarithromycin-MB was included in complex therapy (detoxification, mucolytic drugs, multivitamins, and metabolices) for 6 patients with NHP after 3 days of ineffective starting therapy, 14 patients with emergency received clarithromycin-MB immediately after admission to the hospital. The drug was administered by intravenous drip for 60 minutes at a dose of $500 \mathrm{mg}$ 2 times a day for 7-10 days. Result. The analysis of the obtained results of clarithromycin-MB therapy showed that clinical success was achieved in all patients. The positive dynamics of clinical indicators was noted already on the 3rd day from the beginning of antibiotic therapy with clarithromycin-MB, which was expressed in a decrease in body temperature until the 7th day of treatment, and in almost all patients the temperature returned to normal and only in 1 (5\%) patient remained subfebrile. Also, during this period, patients noted a decrease in pain syndrome as well as signs of intoxication. According to the data of X-ray studies on the 10th day of therapy, 6 (30\%) patients showed complete disappearance of infiltrative changes in the lungs, in 14 (70\%) patients - a significant decrease in their severity. On the 15-24th (average $15.3 \pm 1.2)$ days after the start of therapy signs of inflammatory infiltration in the lungs leveled off on the 15-24th in all patients. Conclusion. Clarithromycin-MB has good therapeutic tolerance, allows maintaining the required concentration in the focus of inflammation because of dosage regimen also affects the clinical and bacteriological effectiveness of therapy.

Key words: non-hospital pneumonia, macrolides, clarithromycin, respiratory failure, laboratory diagnostics

\section{Information about author}

Liadova Tetiana, MD, PhD, Full Prof.

Head of Department of general and clinical immunology and allergology, school of medicine, N.V. Karazin Kharkiv National University, Svobody sq., 6, Kharkiv, Ukraine, 61022

e-mail: t.lyadova@karazin.ua

https://orcid.org/0000-0002-5892-2599

Volobuieva Olha, MD, PhD, Assoc.

Prof., Department of general and clinical immunology and allergology, school of medicine N.V. Karazin Kharkiv National University, Svobody sq., 6, Kharkiv, Ukraine, 61022

e-mail: o.volobyeva@karazin.ua https://orcid.org/0000-0002-5569-1748

Nartov Pavlo, MD, PhD, Full Prof., Department of general and clinical immunology and allergology, school of medicine, N.V. Karazin Kharkiv National University, Svobody sq., 6, Kharkiv, Ukraine, 61022

e-mail:okia.mf@karazin.ua
Malanchuk Svitlana, MD, PhD, Assoc.

Prof., Department of general and clinical immunology and allergology, school of medicine, N.V. Karazin Kharkiv National University, Svobody sq., 6, Kharkiv, Ukraine ,61022

e-mail: s.malanchuk@karazin.ua https://orcid.org/0000-0002-9376-3693

Hololobova Olesia, MD, PhD, Assoc. Prof., Department of general and clinical immunology and allergology, school of medicine N.V. Karazin Kharkiv National University

Svobody sq., 6, Kharkiv, Ukraine, 61022 e-mail: ololesya@ukr.net

https://orcid.org/0000-0002-1713-2988

Kozlov Oleksandr, MD, PhD, Assoc.

Prof., Department of general and clinical immunology and allergology, school of medicine, N.V. Karazin Kharkiv National University, Svobody sq., 6, Kharkiv, Ukraine, 61022

e-mail: kozlov@karazin.ua

https://orcid.org/0000-0003-0320-1505
Kasian Natalia, MD, Assistant of Department of general and clinical immunology and allergology, school of medicine, N.V. Karazin Kharkiv National University, Svobody sq., 6, Kharkiv, Ukraine, 61022

e-mail:n.kasyan@karazin.ua https://orcid.org/0000-0003-4267-7995

Gamilovska Alla, MD, assistant of Department of general and clinical immunology and allergology, school of medicine N.V. Karazin Kharkiv National University, Svobody sq., 6, Kharkiv, Ukraine, 61022

e-mail: gamilovska@karazin.ua https://orcid.org/0000-0002-6652-0952

Shander Tetiana, MD, assistant of Department of general and clinical immunology and allergology, school of medicine, N.V. Karazin Kharkiv National University, Svobody sq., 6, Kharkiv, Ukraine, 61022

e-mail: tanyashander@gmail.com 
The problem of rational antibiotic therapy of pneumonia is among the most relevant in modern medicine. Despite the powerful arsenal of antibacterial agents, we come across an increase in the incidence of pneumonia and its complication [1]. Establishing of this diagnosis is an unconditional indication for the appointment of antibacterial drugs [2,3]. The multidrug resistance of microorganisms, formed as a result of irrational use of antimicrobial drugs, has recently become increasingly important $[4,5]$. A large number of factors have been to date identified, which determined the optimal quality of antimicrobial therapy: the maximum efficiency with the minimal toxicity of drugs should be combined with their correct cost. The results of morbidity control centers studies show that the increase in overall morbidity and mortality is to a large extent due to antibiotic resistance, which leads to a significant increase in the risk of mortality and duration of hospitalization $[4,5]$.

It is known that in the early 90's the concept of evidence-based medicine entered clinical practice, when the treatment tactics and pharmacological drug choice are based on the results of controlled studies, rather than on the subjective experience of the doctor. Within that framework, it is impossible to prescribe antibacterial therapy adequately without monitoring the resistance of microorganisms in a particular department of an infectious disease hospital.

Three classes of antimicrobial drugs exist in modern infectious practice among the most common antibacterial drugs: $\beta$-lactams, fluoroquinolones and macrolides. Macrolides are essential only in the treatment of respiratory and ENT infections, mycobacteriosis, chlamydial and uroplasma infection, soft tissues and skin, as well as pelvic infections.

Modern classification of macrolides includes 3 groups, which are formed depending on the number of carbon atoms in the lactone ring:

I. 14- nomial: erythromycin, clarithromycin, roxithromycin;

II. 15-nomial: (azolides): azithromycin;

III. 16- nomial: spiramycin, josamycin, medicamycin, medicamycin acetate.

The mechanism of action of macrolides is in their ability to contact with $50 \mathrm{~S}$ ribosome unit, which leads to microorganism's protein synthesis inhibition. Accumulating in phagocytes in high concentrations, macrolides contribute to the intracellular death of the pathological agent. Besides, macrolides stimulate mechanisms of nonspecific defense of the organism $[6,7,8]$. The action of this group of antibiotics is usually bacteriostatic, but in high concentrations, they may have bactericidal properties. Such effect is manifested by macrolides against Haemophilus influenzae (H. influenzae), Streptococcus pyogenes (S. pyogenes), Moraxella catarrhalis (M. catarrhalis), Streptococcus agalactiae (S. agalactiae), Neisseria gonorrhoeae (N. gonorrhoeae), Streptococcus pneumonia (S. pneumonia) [6].

Clarithromycin is a representative group of macrolides, approved for use in 1991. The drug is available in two forms: tablets for oral use and powder for solution for infusion. Structurally, clarithromycin is a semi-synthetic drug, its antimicrobial action is due to the ability to block protein synthesis by a microbial cell. At the same time, its immunomodulatory and antiinflammatory effects occurs due to increasing the phagocytes ability to chemotaxis. Clarithromycin increases the phagocytic activity of macrophages and neutrophils [9]. Synergistic bactericidal effects of blood serum complement and clarithromycin were revealed. Presence of clarithromycin increases the T-killers activity, which is probably important in the treatment of patients with bacterial infections complicated by viral super-infections [10]. The antiinflammatory effect is due to a decrease in the activity of cyclooxygenase and lipoxygenase cells. It has become recently known about the inhibition of the mediator chain of proinflammatory cytokines, such as interleukin-6, tumor necrosis factor- $\alpha$ [11], which significantly increased the efficiency of treatment in severe forms of ventilator-associated pneumonia [12]. In patients with respiratory infections, clarithromycin inhibits the formation of sputum and improves its rheological properties [13]. All this became the basis for the use of clarithromycin as an etiotropic drug for the treatment of patients with non-hospital pneumonia (NHP). 
The aim of the study was to evaluate clinical efficiency and therapeutic tolerability of clarithromycin in a parenteral use form for the treatment of patients with non-hospital pneumonia.

Materials and methods. There were 20 patients under our supervision in whom the signs of NHP were radiologically confirmed, which required hospitalization. This study included 12 men $-(60 \%), 8$ women $-(40 \%)$, the average age of patients was $46.1 \pm 17.6$ years. According to the order of the Ministry of Health of Ukraine №128 from 19.03.2007 it is recommended to divide the NHP into 4 groups depending on the severity of the process [2]. All examined patients belonged to the 4th group of patients with severe NHP course and required hospitalization in the intensive care unit. Clinical examination, chest radiography, electrocardiography, clinical and biochemical blood tests, urine and sputum tests were performed before the therapy, after 3 days and after 10 days of therapy. At the same time bacteriological examination of sputum and identification of microorganisms from hemoculture with an assessment of their sensitivity to antibacterial drugs (disc-diffusion method) were performed. Serological test was performed before treatment to detect $\mathrm{Cl}$. pneumoniae, $\mathrm{Cl}$. psittaci, Mycoplasma pneumoniae, Legionella pneumophila, Coxiella burnetii. Morning sputum obtained with appropriate preparation was used for microbiological examination. In order to determine the suitability of the sputum sample for culture, bacterioscopy of Gram-stained smears was performed. The material was considered high quality in the presence of $>25$ polymorphonuclear leukocytes and $<10$ epithelial cells in the field of view at low magnification $(\times 100)-\mathrm{V}$ and VI classes by P. R. Murray, J. A. Washington. According to the results of bacteriological research, the causative agent of NHP was isolated in $84.8 \%$ of patients. The main pathogens were $\mathrm{S}$. pneumoniae, $\mathrm{H}$. influenzae and Kl. pneumoniae. All isolated strains of $\mathrm{S}$. pneumoniae remained highly sensitive to protected aminopenicillins, cephalosporins of the III generation and clarithromycin. Isolated strains of Haemophilus influenzae were sensitive to aminopenicillins, clarithromycin, azithromycin and ceftriaxone. Strains of K. pneumoniae that are not sensitive to clarithromycin and azithromycin were not detected.

In view of the isolation and identification of the NHP causative agent usually requires at least 3 days, the initial antibacterial therapy was performed with drugs of different groups: cefepime, meropenem, augmentin, levofloxacin, ceftriaxone. All patients had clinical symptoms of severe infectious lesions of the lower respiratory tract, namely: temperature, shortness of breath, cough, chest pain, severe signs of intoxication (table 1).

Table 1. Clinical manifestations of non-hospital pneumonia before the beginning of clarithromycin-MB therapy $(n=20)$

\begin{tabular}{|c|c|c|}
\hline Symptoms of the disease & Abs. & \% \\
\hline Cough & 20 & 100 \\
\hline Symptoms of intoxication & 20 & 100 \\
\hline Temperature & 20 & 100 \\
\hline Shortness of breath & 15 & 75,0 \\
\hline Pleural pain & 9 & 45,0 \\
\hline Hemoptysis & 4 & 20,0 \\
\hline Bronchial breathing & 4 & 20,0 \\
\hline Impaired breathing & 18 & 90,0 \\
\hline Presence of sputum & 17 & 85,0 \\
\hline Wheezing, crepitus, pleural rub & 16 & 80,0 \\
\hline Unilateral lesion & 5 & 25,0 \\
\hline Bilateral lesion & 15 & 75,0 \\
\hline
\end{tabular}


In the majority of patients percussion and auscultatory signs dominated in the clinic of NHP, which indicated pathology of the lung tissue. In $75.0 \%$ of cases (15 patients) bilateral lung lesion was noted. It should be mentioned that at unilateral lesion of pulmonary fabric changes were found on the right - at $25 \%$ of cases (5 patients). Hemoptysis was observed in $4(20 \%)$ patients. All patients had leukocytosis with a shift of the leukocyte formula to the left. Anemia was detected in $4(20 \%)$ patients with NHP. Elevated ESR was observed in $85 \%$ of cases (17 patients).

Clarithromycin-MB was included in the complex therapy (detoxification, mucolytic drugs, multivitamins, metabolites) in 6 patients with NHP after 3 days of ineffective initial therapy, 14 patients with NHP received clarithromycin-MB immediately after admission to the hospital. The drug was administered intravenously drip for 60 minutes at a dose of $500 \mathrm{mg} 2$ times a day for 7-10 days.

The clinical efficiency of antibacterial therapy was assessed by the dynamics of the inflammatory process activity in the lungs. For this purpose, the following clinical and laboratory parameters characterizing the activity of the inflammatory process (temperature reaction, tachycardia, respiratory rate, leukocytosis, number of immature granulocytes, changes in ESR) as well as the severity of pain, radiological changes in the lungs were assessed. The dynamics of clinical and laboratory signs were taken into account before treatment, during treatment (3-5 days of therapy) and on the10th day after taking the drug. Radiological efficiency was also assessed at the end of therapy.

The clinical efficacy of clarithromycin-MB antibacterial therapy was assessed as "good" if there was an improvement in the subjective and objective condition of patients, reduction and normalization of body temperature, disappearance of pain syndrome, a steady tendency to normalize laboratory parameters on the 3rd day of therapy The efficiency of antibacterial therapy was assessed as "satisfactory", if there was an unstable improvement in laboratory parameters and persisted sub-febrile condition on the background of subjective improvement of patients. "Unsatisfactory" results of the treatment without the improvement of the patients' condition and absence of the tendency to normalize laboratory parameters were not noticed in our observations.

The results of radiological data of the chest were interpreted in the following way: "improvement" - with positive dynamics or complete disappearance of radiological signs of NHP, "no changes" - absence of improvement compared to the original radiological picture.

Statistical processing of the obtained research results was performed using the program STATISTIKA for Windows (Stat Soft Inc, USA) on a computer with a Pentium II Celeron 850 PPGA processor.

Research results. Analysis of the received results of clarithromycin-MB therapy demonstrated that clinical success was achieved in all patients (fig.1).

Positive dynamics of clinical indicators was observed on the 3rd day from the beginning of clarithromycin-MB antibacterial therapy, which was expressed in lowering of body temperature, almost all patients had normalized temperature by the 7th day of treatment and only in $1(5 \%)$ patient the sub-febrile condition was kept. In this period patients also noted a decrease in pain syndrome, they had reduced signs of intoxication (Fig. 1). Analyzing laboratory parameters, we reliably found that the ESR acceleration rate decreased on the average from $26.4 \pm 2.9$ to $7.3 \pm 0.8 \mathrm{~mm} / \mathrm{h}$ (p $<0.05$ ); the number of leukocytes - from $12.5 \pm 1.5$ $\mathrm{x} 109 / 1$ to $6.2 \pm 0.5 \times 109 / 1(\mathrm{p}<0.05)$ up to the 10th-12th day of therapy 


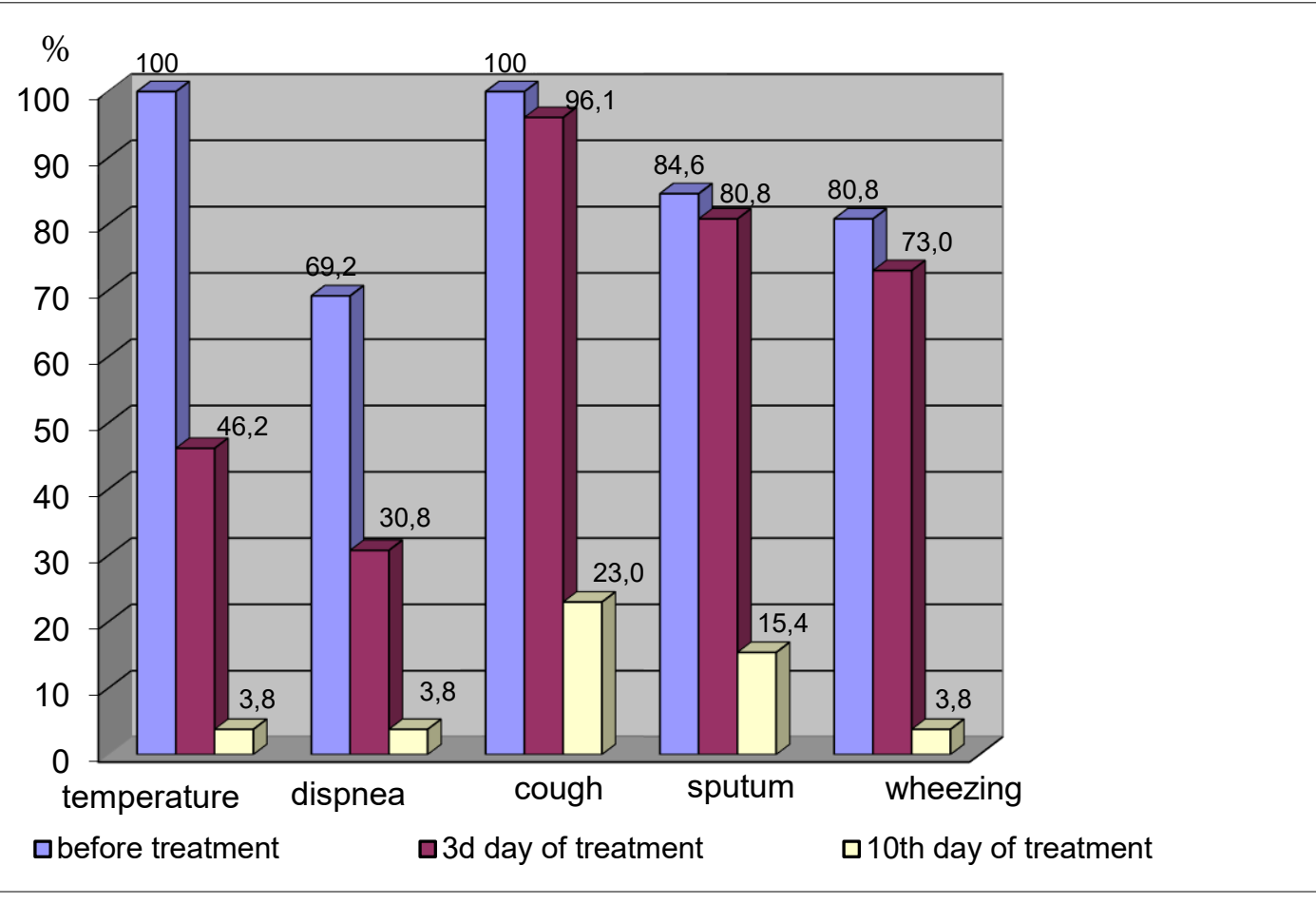

Fig. 1. Dynamics of main clinical symptoms in patients with NHP with clarithromycin therapy

According to radiological studies in $6(30 \%)$ patients there was a complete disappearance of infiltrative changes in the lungs, in 14 (70\%) patients - a significant decrease in their severity on the 10th day of therapy. Signs of inflammatory infiltration in the lungs were not detected in all patients on the 15 th-21st (on the average $15.3 \pm 1.2$ ) day after the start of therapy. It is important to mention that side effects from clarithromycin-MB therapy were observed in 3 patients in the form of nausea and short-term loosening of stool in one patient. These phenomena were momentary and did not require correction and withdrawal of the drug.

Conclusions. Macrolide Clarithromycin-MB in parenteral form of application is a highly effective antibacterial drug for the treatment of severe NHP. Positive dynamics of clinical manifestations of the disease was observed on the 3rd day from the beginning of therapy.

Clarithromycin-MB has good therapeutic tolerability in patients with NHP. The identified side effects were momentary and did not require additional drug correction and drug withdrawal. Dosage regimen $(500 \mathrm{mg} 2$ times a day intravenously drip for 60 minutes for 7-10 days) allows maintaining the required concentration in the focus of inflammation, which affects the clinical and bacteriological efficiency of therapy.

\section{References}

1. Shikhnebiev DA, Modern approaches to antimicrobial therapy of community-acquired pneumonia (literature review). International Journal of Applied and Basic Research. 2014; 4: 101-104.

2. Protocol of good medical assistance We have a problem with non-hospital and nosocomial (hospital) pneumonia in older adults: etiology, pathogenesis, classification, diagnostics, antibacterial therapy. Order of the Ministry of Health of Ukraine No. 128 dated 19.03. 2007 p.

3. Feshchenko YuI, Golubovska OA, Goncharov KA, Dziublyk OYa, Dziublyk YaO, Dmitrichenko VV, Kapitan GB, Kliagin VYa, Mostovyi YuM, Mukhin OO, Nedlinska NM, Obertynska OV, Pertseva TO, Pylypenko MM, Simonov SS, Sukhin RYe, Shlapak IP, Yudina LV. Community-acquired pneumonia in adults: etiology, pathogenesis, classification, diagnosis, antibiotic therapy (draft clinical guidelines) Part II. Ukrainian pulmonological journal. 2013;1:5-21.

4. Antimicrobial Resistance, Electronic source: http://www.who.int/ drugresistance/en/

5. Sahm DF, Antimicrobial resistance trends among sinus isolates of Streptococcus pneumoniae in the United States (20012005). Otolaryngol. Head Neck Surg. 2007;- 136 (3):385-389.

6. Strachunsky HP, Kozlov SN, Macrolides in modern clinical practice. Clinical medicine. 2012;3:23-30.

7. Greenwood D, Antimicrobial Chemotherapy, Oxford.1995;4:43-49. 
8. Labro MT, Antibiotics as anti-inflammatory drugs. Current Opinion in Investigational Drugs. 2002.

9. Kohno SA, New macrolide, TE-031 (A-56268), in treatment of experimental Legionnais' disease. J. Antimicrob. Chemother.1989;24:397-405.

10. Takeda H, Long-term administration study on TE-031 (A-56268) in treatment of diffuse panbronchiolitis.1989;63:7178.

11. Gogos CA, Drosou E, Bassaris HP, Skoutelis A, Proversus anti-inflammatory cytokine profile in patients with severe sepsis: a marker for prognosis and future therapeutic options. J. Infect. Dis.2002;181:176-180.
12. Giamarellos-Bourboulis EJ, Pechère JC, Routsi C, Effect of clarithromycin in patients with sepsis and ventilatorassociated pneumonia. Clin. Infect. Dis.2008;46(8):11571164. doi: $10.1086 / 529439$.

13. Averyanov AV, Zykov KA, Clarithromycin in the treatment of exacerbations of chronic obstructive pulmonary disease. Ukr. pulmonol. magazine. 2009; 2: 48-52.

14. Norimichi A, Naoki I, Kazutaka M, Yutaro N, Hiroshi H. Effect of rifampicin and clarithromycin on the CYP3A activity in patients with Mycobacterium avium complex. J Thorac Dis.2019;11(9):3814-3821. DOI: 10.21037/jtd.2019.09.06.

\title{
КЛНІЧНА ЕФЕКТИВНІСТЬ КЛАРИТРОМЩИНУ-МБ В КОМПЛЕКСНІЙ ТЕРАПЇ ХВОРИХ НА НЕГОСПІТАЛЬНУ ПНЕВМОНІЮ
}

\author{
Лядова Т. І., Волобуєва О. В., Нартов П. В., Маланчук С. Г., Гололобова О. В., Козлов О. П., Касьян Н. В., \\ Гаміловска А. П., Шандер Т. А.
}

Пошта для листування: o.volobyeva @ karazin.ua

\begin{abstract}
Резюме: Проблема раиіональної антибіотикотерапії пневмонії залпиається однією з найбільш актуальних у сучасній медицині. Метою дослідження була оиінка клінічної ефективності та терапевтичної переносимості кларитроміиину для парентерального застосування у лікуванні хворих на негоспітальну пневмонію (НП). Матеріали та методи. Під нашим спостереженням знаходилися 20 паиієнтів: 12 чоловіків - (60\%), 8жінок - (40\%), середній вік хворих становив 46, 1 $\pm 17,6$ року. У всіх паміснтів спостерігалася клінічна симптоматика тяюского інфекиійного уражсення ниюних дихальних шляхів. У 73,0\% (15 хворих) зазначалося двобічне уражсення легень, у 27\% (5 хворих) - односторонне уражсення легеневої тканини. Кровохаркання відмічалося у 4 (20\%) паиієнтів. В комплексну терапію (дезінтоксикаиійні, муколітичні препарати, полівітаміни, метаболіки) 6 хвории на НП включали Кларитроміицн-МБ через 3 доби неефективної стартової терапії, 14 хворихна НПотримували кларитромічин-МБ відразу після надходження до стаиіонару. Препарат вводили внутрішньовенно крапельно трівалістю 60 хвилин в дозі 500 мг 2 рази на добу протягом 7-10 діб. Результати. Аналіз отриманих результатів терапії кларитромицином-МБ показав, що клінічний успіх був досягнутий у всіх паиієнтів. Позитивна динаміка клінічних показників відзначалася вже на 3-й день від початку антибактеріальної терапї кларитроміцином-МБ, що виражкалося в зниюсенні температури тіла, до 7-го дня лікування практично у всіх хворих температура нормалізувалася і тільки у 1 (5\%) хворого зберігалася субфебрильною. Також памієнти в ией період відзначали зменшення больового синдрому, у них знижувалися ознаки інтоксикаиії. За даними рентгенологічних досліджень на 10-й день терапії у 6 (30\%) хворих відзначалося повне зникнения інфільтративних змін в легенях, у 14 (70\%) хворих - значне зменшення їх виражкеності. У всіх хворих ознаки запальної інфільтрації в легенях не виявлялися на 15-24-й (в середньому 15,3 \pm 1,2) день після початку терапії. Висновки. Кларитроміиин-МБ має гарну терапевтичну переносимість, резжим дозування дозволяє підтримувати необхідну конщентрамію у вогничі запалення, щю впливає на клінічну і бактеріологічну ефективність терапії.
\end{abstract}

Ключові слова: негоспітальна пневмонія, макроліди, кларитроміцин, дихальна недостатність, лабораторна діагностика

\footnotetext{
Інформація про авторів

Лядова Тетяна Іванівна, д. мед. н., проф., зав. кафедри загальної та клінічної імунології та алергології медичного факультету Харківського національного університету імені В. Н. Каразіна, майдан Свободи, 6, Харків, Україна, 61022

e-mail: t.lyadova@karazin.ua

https://orcid.org/0000-0002-5892-2599

Волобуєва Ольга Вікторівна, к. мед. н., доц. кафедри загальної та клінічної імунології та алергології медичного факультету Харківського

національного університету імені В. Н. Каразіна,

майдан Свободи, 6, Харків, Україна, 61022

e-mail: o.volobyeva@karazin.ua https://orcid.org/0000-0002-5569-1748

Нартов Павло Вікторович, д. мед. н., проф. кафедри загальної та клінічної імунології та алергології медичного факультету Харківського національного університету імені В. Н. Каразіна, майдан Свободи, 6, Харків, Україна, 61022
}

e-mail:okia.mf@karazin.ua

Маланчук Світлана Генадївна, к. б. н., доц. кафедри загальної та клінічної імунології та алергології медичного факультету Харківського національного університету імені В. Н. Каразіна, майдан Свободи, 6, Харків, Україна 61022

e-mail: s.malanchuk@karazin.ua https://orcid.org/0000-0002-9376-3693

Гололобова Олеся Василівна, к. мед. н., доц. кафедри загальної та клінічної імунології та алергології медичного 
факультету Харківського національного університету імені В. Н. Каразіна, майдан Свободи, 6, Харків, Україна, 61022

e-mail: gololesya@ukr.net

https://orcid.org/0000-0002-1713-2988

Козлов Олександр Петрович, к. мед. н., доц. кафедри загальної та клінічної імунології та алергології медичного факультету Харківського національного університету імені В. Н. Каразіна, майдан Свободи, 6, Харків, Україна, 61022

e-mail:kozlov@karazin.ua https://orcid.org/0000-0003-0320-1505

Касьян Наталія Володимирівна, асистент кафедри загальної та клінічної імунології та алергології медичного факультету Харківського національного університету імені В.Н. Каразіна, майдан Свободи, 6, Харків, Україна, 61022

e-mail: n.kasyan@karazin.ua https://orcid.org/0000-0003-4267-7995

Гаміловська Алла Петрівна, асистент кафедри загальної та клінічної імунології та алергології медичного факультету Харківського національного університету імені В. Н. Каразіна, майдан Свободи, 6, Харків, Україна, 61022

e-mail: gamilovska@ karazin.ua https://orcid.org/0000-0002-6652-0952

Шандер Тетяна Анатолївна, асистент кафедри загальної та клінічної імунології та алергології медичного факультету Харківського національного університету імені В. Н. Каразіна, майдан Свободи, 6, Харків, Україна, 61022

e-mail: tanyashander@gmail.com

\title{
КЛИНИЧЕСКАЯ ЭФФЕКТИВНОСТЬ КЛАРИТРОМИЦИНА-МБ В КОМПЛЕКСНОЙ ТЕРАПИИ БОЛЬНЫХ НЕГОСПИТАЛЬНОЙ ПНЕВМОНИЕЙ
}

\author{
Лядова Т. И., Волобуева О. В., Нартов П.В., Маланчук С. Г., Гололобова О. В., Козлов А. П., \\ Касьян Н. В., Гамиловская А. П., Шандер Т. А.
}

Пошта для листування: o.volobyeva@karazin.ua

Резюме. Проблема рациональной антибактериальной терапии пневмонии остается одной из самых актуальных в современной медицине. Целью исследования была оценка клинической эффективности и терапевтической переносимости кларитромицина для парентерального применения в лечении больных негоспитальной пневмонией (НП). Материалы и методы. Под натим наблюдением находились 20 пациентов: 12 мужчин - (60\%), 8 женщин - (40\%), средний возраст больных составил 46,1 1 17,6 года. У всех пациентов наблюдалась клиническая симптоматика тяжелого инфекиионного поражения нижних дыхательных путей. В 75,0\% (15 больных) отмечалось двустороннее поражение легких, в 27\% (5 больных) - односторонне поражения легочной ткани. Кровохарканье отмечалось у 4 (20\%) пациентов. $B$ комплексную терапию (дезинтоксикационные, муколитические препараты, поливитамины, метаболика) 6 больным НП включали Кларитромицин-МБ через 3 суток неэффективной стартовой терапии, 14 больных ЧП получали кларитромицин-МБ сразу после поступления в стачионар. Препарат вводили внутривенно капельно продолжительностью 60 минут в дозе 500 мг 2 раза в сутки в течение 7-10 суток. Результаты. Анализ полученных результатов терапии кларитромицином-МБ показал, что клинический успех был достигнут у всех пациентов. Положительная динамика клинических показателей отмечалась уже на 3-й день от начала антибактериальной терапии кларитромицином-МБ, что выражалось 8 снижении температуры тела до 7-го дня лечения и практически у всех больных температура нормализовалась и только у 1 (5\%) больного сохранялась субфебрильной. Также пациенты в этот период отмечали уменьшение болевого синдрома, у них снижались признаки интоксикачии. По данным рентгенологических исследований на 10-й день терапии у 6 (30\%) больных отмечалось полное исчезновение инфильтративных изменений в легких, у 14 (70\%) больных - значительное уменьшение их выраженности. У всех больных признаки воспалительной инфильтрации в легких нивелировались на 15 24-й (в среднем 15,3 \pm 1,2) день после начала терапии. Выводы. Кларитромицин-МБ имеет хоромую терапевтическую переносимость, режим дозирования позволяет поддерживать необходимую кониентрацию в очаге воспаления, влияет на клиническую и бактериологическую эффективность терапии.

Ключевые слова: негоспитальная пневмония, макролиды, кларитромицин, дыхательная недостаточность, лабораторная диагностика

\footnotetext{
Информация об авторах

Лядова Татьяна Ивановна, д. мед. н., проф., зав. кафедры общей и клинической иммунологии и аллергологии медицинского факультета Харьковского национального университета имени В. Н. Каразина, пл. Свободы, 6, Харьков, Украина, 61022 e-mail: t.lyadova@karazin.ua
}

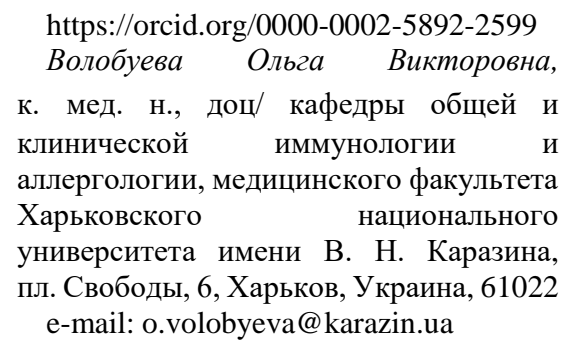

https://orcid.org/0000-0002-5569-1748

Нартов Павел Викторович, д. мед. н., проф. кафедры общей и клинической иммунологии и аллергологии медицинского факультета Харьковского национального университета имени В. Н. Каразина, пл. Свободы, 6, Харьков, Украина, 61022

e-mail:okia.mf@karazin.ua 
Actual problems of modern medicine. Issue 6, 2020

Маланчук Светлана Геннадиевна, к. б. н., доц. кафедры общей и клинической иммунологии и аллергологии, медицинского факультета Харьковского национального университета имени В. Н. Каразина, пл. Свободы, 6, Харьков, Украина, 61022 e-mail: s.malanchuk@karazin.ua https://orcid.org/0000-0002-9376-3693

Гололобова Олеся Васильевна, к. мед. н., доц. кафедры общей и клинической иммунологии и аллергологии медицинского факультета Харьковского национального университета имени В. Н. Каразина, пл Свободы, 6, г. Харьков, Украина, 61022 e-mail: ololesya@ukr.net https://orcid.org/0000-0002-1713-2988 Козлов Александр Петрович, к. мед. н., доц. кафедры общей и клинической иммунологии и аллергологии медицинского факультета Харьковского национального университета имени В. Н. Каразина пл. Свободы, 6, Харьков, Украина, 61022 e-mail:kozlov@karazin.ua https://orcid.org/0000-0003-0320-1505

Касьян Наталья Владимировна, ассистент кафедры общей и клинической иммунологии и аллергологии медицинского факультета Харьковского национального университета имени В. Н. Каразина, пл. Свободы, 6, Харьков, Украина, 61022 e-mail: n.kasyan@karazin.ua https://orcid.org/0000-0003-4267-7995 Гамиловская Алла Петровна,
ассистент кафедры общей и клинической иммунологии и аллергологии медицинского факультета Харьковского национального университета имени В. Н. Каразина пл. Свободы, 6, Харьков, Украина, 61022 e-mail: gamilovska@ karazin.ua https://orcid.org/0000-0002-6652-0952
Шандер Татьяна Анатольевна, ассистент кафедры общей и клинической иммунологии и аллергологии медицинского факультета Харьковского национального университета имени В. Н. Каразина, пл. Свободы, 6, Харьков, Украина, 61022 e-mail: tanyashander@gmail.com

Conflicts of interest: author has no conflict of interest to declare.

Конфлікт інтересів: відсутній.

Конфликт интересов: отсутствует. 


\title{
PHENOMENON OF TEXT NECK IN HIGHER EDUCATION STUDENTS
}

\author{
Nikolenko Evgene, Adamovych Iryna, Vovk Kira
}

Mail for correspondence: i.adamovich@karazin.ua

\begin{abstract}
Summary: In the modern world almost all young people use smartphones and now most of the time using mobile phones belongs to additional functions. Regrettably, consequences for the musculokeletal system are not considered. It is a known fact that long-term use of the gadgets causes excessive cervical spine bending, improper posture and the formation of muscular-tonic syndrome accompanied by the pain and discomfort that is so-called "Text neck" syndrome.

The aim of the research was to study the impact of using gadgets on the formation pain syndrome in the neck and shoulders, as well as headache.

The research involved 90 respondents, 60 female and 30 males, the age of the participants was in a range from 18 to 28 years old. Using a self-created questionnaire, applying in Google docs, Text neck symptoms such as headache, pain/discomfort in the neck and shoulder, as well as awareness of this phenomenon have been evaluated.

The study has shown the primary role of the shoulder pain/discomfort among respondents, thus 59 (66\%) of the participants suffer from shoulder pain/discomfort in different degrees with the gender distribution as follows: 46 women (76\%) and 13 men (43\%). Headache was noted by 56\% of the participants and $50 \%$ suffer from neck pain/discomfort. The average phone usage time was 5.3 hours.

Only one third (32\%) of respondents associated their symptoms with the use of gadgets, so the study has demonstrated low awareness about this syndrome among students. Young people do not realize devastating impact of the gadgets on the health condition, in particular musculoskeletal system.

Thus, the authors believe that an integrated approach is needed on the part of the family, educational establishments and health care with a view to build awareness in young people and prevent Text neck formation. Seems like a reasonable implementation of the course on the possible impact of excessive gadgets use on the health condition of the students at higher education institutions.
\end{abstract}

Key words: students, Text neck, poor posture

Information about author

Nikolenko Evgene, MD, PhD, Full Prof. Head of the Department of General Practice-Family Medicine, School of Medicine, N.V. Karazin Kharkiv National University, Svobody sq., 6, Kharkiv, Ukraine, 61022

e-mail: e.nikolenko@karazin.ua https://orcid.org/0000-0002-7653-0644 Adamovych Iryna, Assistant of the Department of General Practice-Family Medicine, School of Medicine N.V. Karazin Kharkiv National University, Svobody sq., 6, Kharkiv, Ukraine, 61022 e-mail: I.adamovich@ karazin.ua https://orcid.org/0000-0002-8934-7291
Vovk Kira, PhD, Assoc. Prof. of the Department of General Practice-Family Medicine, School of Medicine, N.V. Karazin Kharkiv National University, Svobody sq., 6, Kharkiv, Ukraine ,61022 e-mail: vovkkira1970@gmail.com https://orcid.org/0000-0003-2971-0842

\section{Introduction}

Life in the modern world implies the widespread use of various devices, that undoubtedly has a lot of advantages. Almost all young people use gadgets [1], but if earlier these devices were used mainly for conversations, now most of the time using mobile phones belongs to additional functions, such as viewing social networks, chatting in messenger applications, games as well as for work purposes [2]. Nevertheless, the digital era is challenging for the modern mind as well as for the health condition and can contribute to severe health problems. If a person constantly bends one's head to look at a small screen, different problems can arise, such as a forward-head posture or a slouched, turtle-like posture and this posture induces muscle strain $[3,4,5]$.

So, widespread excessive use of mobile devices can lead to the phenomenon named "Text Neck" invented by Dr. Dean Fishman a Chiropractor in Plantation Florida. Text Neck means formation of poor posture and musculartonic syndrome caused by the frequent tilting the head downwards due to excessive texting and overuse of all handheld electronic devices [6]. Text Neck is a relatively new term but it is a common problem of the world now.

This unnatural posture could be observed earlier during reading but now it is a specially 
concerning that a forward-head posture operates on a much larger scale as a result of young people addiction to devices.

Undoubtedly, Text Neck caused not only by over-reliance of mobile phones but different types of handled devices, such as tablets, game consoles contribute to this condition.

Nevertheless, young people not always can realize that devastating effect of using their cell phones and connect their symptoms such as shoulder pain or neck pain with the excessive use of these devices.

Owing to the fact that this issue becomes extremely important different researches are carried out $[7,8,9]$. The review of Yanfei Xie et al. [10] revealed evidence for neck flexion, frequency of phone calls, texting and gaming in relation to musculoskeletal complaints among mobile device users demonstrated that the prevalence of musculoskeletal complaints in those who used mobile device varies from $1.0 \%$ to $67.8 \%$ and neck complaints were the most common with the range from $17.3 \%$ to $67.8 \%$.

According to studies by Pankti P. Samani et al. [11] of awareness of Text-neck syndrome among young-adult population living in Mumbai and Pune cities of Maharashtra, just 35\% population has heard about this term with the $8 \%$ people could figure out in this issue. Spine specialists of the Spine Institute of North America are also concerned with this phenomenon [12] and give information and tips for prevention Text neck on their website.

There are no literature sources regarding youth population in our country, therefore we consider it reasonable to investigate this issue in our endeavour.

The aim of the research was to study the impact of using gadgets on the formation pain syndrome in the neck and shoulders, as well as headache using identifying the incidence of Text neck symptoms among students of higher educational institutions.

\section{Materials and methods}

The study was performed among students of higher educational institutions. All the respondents expressed informed consent for the participation in the survey.

We figured out the connection between the amount of time spent in the front of mobile phone and the presence of the symptoms of "Text neck" through questionnaires distributed to participants.

90 subjects were included in the study with the distinction on the basis of gender as follows. 30 male $(33 \%)$ and 60 female $(67 \%)$ respondents participated in the research. The age of the responders was in a range from 18 to 28 years old.

The criteria for exclusion from the study was presence of musculoskeletal diseases, congenital cervical damages or traumas that could affect the outcome.

A self-invented questionnaire was made in Google docs. The following information was included: 1) The duration of using mobile phone daily; 2) Whether the symptoms like pain/tightness in the neck, pain/malaise in the shoulders, headache bother the participants; 3) If the students know what does it mean Text neck and connect their symptoms if the presence with the prolonged use of the cell phone.

Data analysis. Descriptive statistics was conducted to evaluate the responses obtained from the subjects. The percentage of responses for each question was calculated.

Results In the study we determined the average time of using cell phones that was 5,3 hour (from 1,5 hour up to 16 hours).

The distribution of the answers is illustrated in the figures $1-3$. Thus, $45(51 \%)$ of the participants did not suffer from pain/discomfort in the neck, $24(27 \%)$ felt pain 1-2 times monthly, 11 (12\%) 1-2 times in a week, 10 $(11 \%)$ suffered from pain with the frequency more than 3 times per week (Fig.1). 


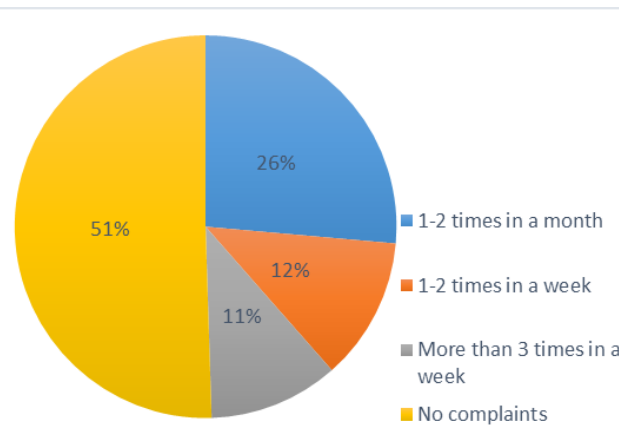

Fig. 1. Distribution of pain/discomfort in the neck among all participants

Figure 2 shows the percentage of the responders suffering from the shoulder pain//discomfort.

$31(34 \%)$ did not feel the shoulder pain. Dispersion of the frequency was as follows. 1-2 times in a month - 26 (29\%), 1-2 times in a week - $18(20 \%)$, more than 3 times per week 15

(17\%).

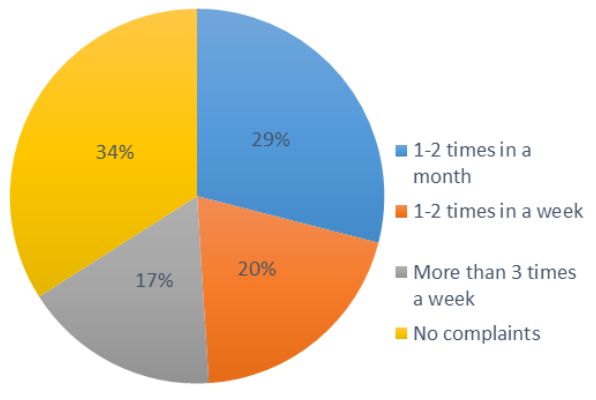

Fig.2. Distribution of shoulder pain/discomfort among all participants

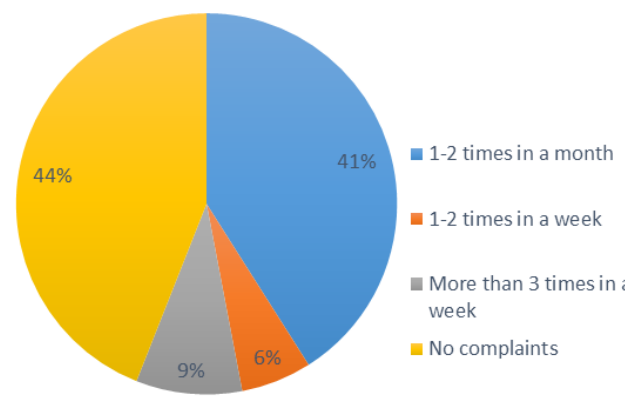

Fig. 3. Distribution of headache among all participants
Figure 3 shows spread of headache in all responders.

Neck complaints were not observed in 24 women from 60 (40\%), 3 times per week 10 (17\%), 1-2 times weekly 9 (15\%), 1-2 times in a month 17 (28\%). 24 participants did not note neck pain.

Shoulder pain or discomfort experienced in 46 women $(76 \%)$ with the following range: 1-2 times monthly - 19 (32\%), 1-2 times per week - 13 (21\%), more than 3 times in a week - 14 (23\%). No complain - $14(24 \%)$.

Headache did not bother 22 (37\%) female participants, 1-2 time monthly - 26 (43\%), 1-2 time per week $5(8 \%)$, more than 3 times in a week $-7(12 \%)$.

In men the symptoms were distributed as follows. Neck pain/discomfort were not observed in 21 participants $(70 \%)$. No one felt pain in the neck more than 3 times per week, 1-2- times in a week $-1(3 \%)$, 1-2 times monthly - $8(27 \%)$.

Shoulder pain/discomfort was the most commonly notified symptom in male participants. Thus, 17 (57\%) participants did not have this symptom. Nevertheless, 7 (23\%) noticed the pain 1-2 times monthly, 5 (17\%) 1-2 times in a week and $1(3 \%) 3$ times in a week.

The incidence of headache among male participants was as follows. No headache 17 (57\%) participants, 1-2 times in a month - 11 (37\%), 1-2 times weekly $-1(3 \%)$, more than 3 times in a week - $1(3 \%)$.

When comparing data about the symptoms of Text neck in men and women the difference is obvious. Each complaint occured more frequently in female participants (Fig. 4-6).

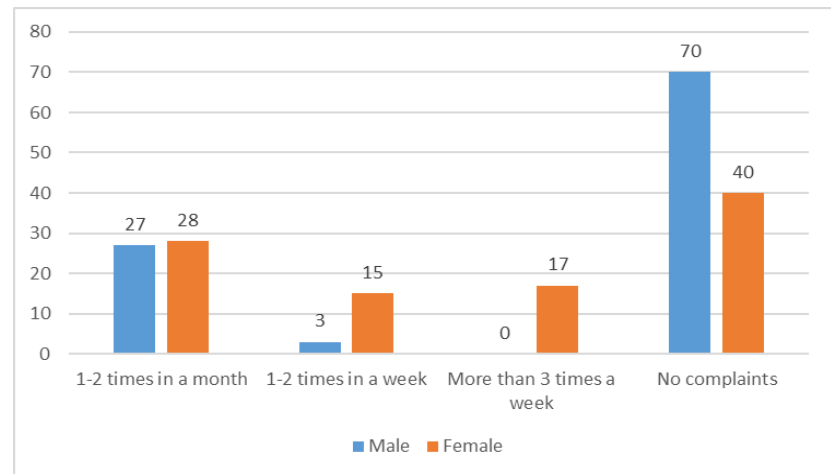

Fig. 4. Comparison the incidence rate of neck pain/discomfort in male and female 


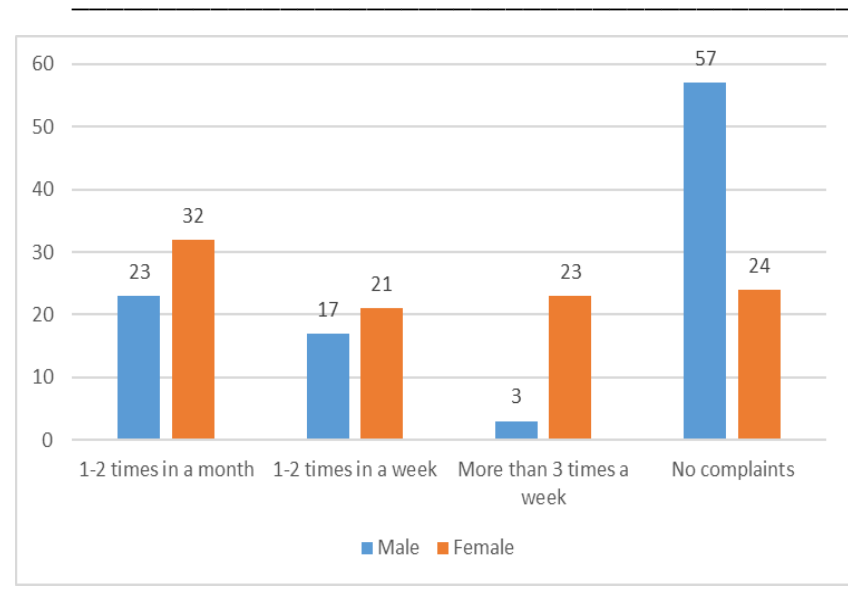

Fig. 5. Comparison the incidence rate of shoulder pain/discomfort in male and female

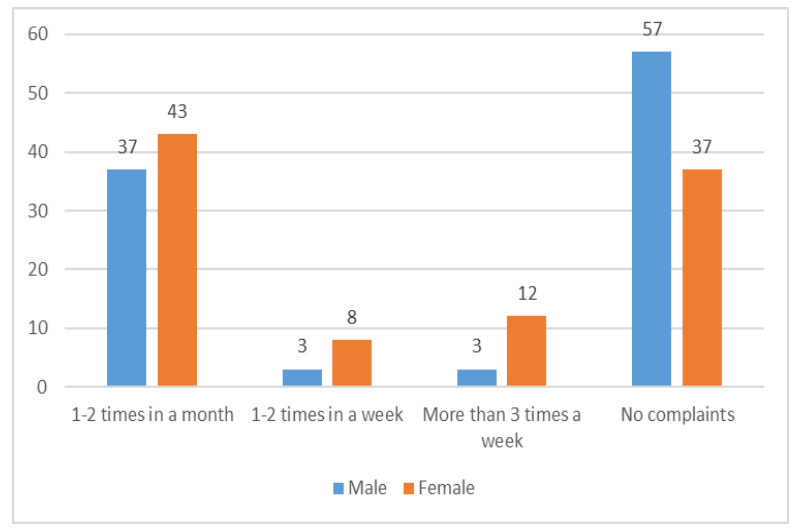

Fig. 6. Comparison the incidence rate of headache in male and female

When interviewed about the knowledge of Text neck just $23 \%$ of responders knew about this phenomenon (Fig. 7) and 32\% connected their symptoms with overuse of smartphone (Fig.8).

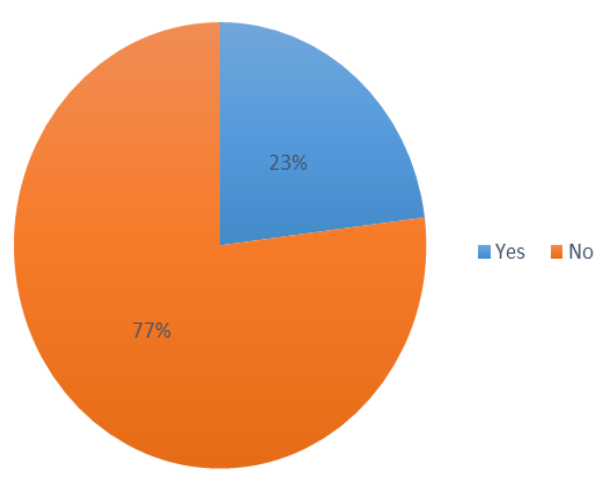

Fig. 7. Awareness of Text neck among responders

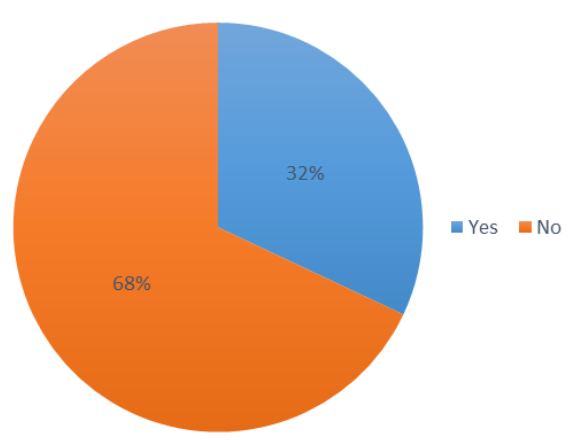

Fig. 8. Connection the symptoms with overuse of cell phone

\section{Conclusion}

1.The study has shown the primary role of the shoulder pain/discomfort among respondents, thus $59(66 \%)$ of the participants suffer from shoulder pain/discomfort in different degrees with the gender distribution as follows: 46 women $(76 \%)$ and 13 men $(43 \%)$.

2.One third of respondents associated their symptoms with the use of gadgets.

Young people do not realize devastating impact of the gadgets on the health condition, in particular musculoskeletal system. We are of the opinion that development of new more flexible questionnaires for identifying risk factors and prevention of this phenomenon is prospectively.

3.An integrated approach is needed on the part of the family, educational establishments and health care with a view to build awareness in young people and prevent Text neck formation. We consider it reasonable to introduce course on the gadgets' impact on the health condition of the students at higher education institutions of Ukraine.

\section{References}

1. Toh SH, Howie EK, Coenen P, Straker LM. "From the moment I wake up I will use it...every day, very hour": a qualitative study on the patterns of adolescents' mobile touch screen device use from adolescent and parent perspectives. BMC Pediatr. 2019 Jan 24;19(1):30. DOI: 10.1186/s12887-019-13995

2. Lauricella AR, Cingel DP, Blackwell $\mathrm{C}$ et al. The mobile generation: youth and adolescent ownership and use of new media. Comm Res. Rep. 2014;31(4):357-364. DOI:10.1080/08824096.2014.963221

3. Lee S, Lee D, Park J. Effect of the cervical flexion angle during smart phone use on muscle fatigue of the cervical erector spinae and upper trapezius. J Phys Ther Sci. 2015 Jun; 27(6): 18471849. doi: $10.1589 /$ jpts. 27.1847 
4. Namwongsa S, Puntumetakul R, Neubert MS, Boucaut R. Effect of neck flexion angles on neck muscle activity among smartphone users with and without neck pain.

Ergonomics. 2019 Dec;62(12):1524-1533. DOI: 10.1080/00140139.2019.1661525

5. Neupane S, Ali UI, Mathew A. Text Neck SyndromeSystematic Review. Imperial $\mathbf{J}$ Interdisciplinary Res. 2017;3(7):141-8. ISSN: 2454-1362, http://www.onlinejournal.in 6. Nizar Abdul Majeed Kutty. Text neck: a global epidemic of the modern era.

MOJ Yoga \& Physical Therapy. Volume 4 Issue 1 - 2019 eISSN: 2573-2927

7. Toh SH, Coenen P, Howie EK, Straker LM. The associations of mobile touch screen device use with musculoskeletal symptoms and exposures: a systematic review. PLoS One. 2017 Aug 7; 12(8). DOI: 10.1371/journal.pone.0181220

8. Smith L, Louw Q, Crous L, Grimmer-Somers K. Prevalence of Neck Pain and Headaches: Impact of Computer Use and Other
Associative Factors. Cephalalgia. 2009 March; 29(2):250-7 DOI: 10.1111/j.1468-2982.2008.01714.x

9. Gustafsson E, Thomée S, Grimby-Ekman A, Hagberg M. Texting on mobile phones and musculoskeletal disorders in young adults: a five year cohort study. Appl ergon. 2017; 58 :20814. DOI: $10.1016 /$ j.apergo.2016.06.012

10.Xie Y, Szeto G, Dai J. Prevalence and risk factors associated with musculoskeletal complaints among users of mobile handheld devices: A systematic review. Applied ergonomics. 2017; 59:132-42. DOI: 10.1016/j.apergo.2016.08.020

11. Pankti P. Samani 1, Neeraj A. Athavale. et al. Awareness of text neck syndrome in young-adult population. Int J Community Med Public Health. 2018 Aug;5(8):3335. DOI: 10.18203/23946040.ijcmph20183057

12. Jason M. Cuéllar, Todd H. Lanman. "Text-neck": an epidemic of the modern era of cell phones? The spine journal: official journal of the North American Spine Society 17(6). March 2017 DOI: 10.1016/j.spinee.2017.03.009.

\title{
ФЕНОМЕН КОМП'ЮТЕРНОЇ ШИЇ СЕРЕД СТУДЕНТІВ ВИЩИХ НАВЧАЛЬНИХ ЗАКЛАДІВ
}

\author{
Ніколенко С. Я., Адамович І. В., Вовк К. В.
}

Пошта для листування: i.adamovich@karazin.ua

Резюме: У сучасному світі практично все молоді люди використовують гаджсти $і$ зараз більша частина часу використання мобільних телефонів належчть додатковим функиіям. На жаль, молоді люди при цзьому не враховують наслідки впливуна стан опорно-рухового апарату. Відомо, щотривале використання гаджетів призводить до надмірного згинання иийного відділу хребта, неправильної постави та формування м'язово-тонічного синдрому, шео супроводжується болем та дискомфортом, тобто синдрому так званої "комп'ютерної ипі" (англ. Техt песк).

Метою даної статті була оиінка впливу використання гаджетів на формування больового синдрому в ииї та плечах, а також головного болю в студентів вищих навчальних закладів.

У дослідженні брали участь 90 респондентів, з них 60 жіночої статі і 30 чоловічої статі, вік учасників становив від 18 до 28 років.. За допомогою самостійно створеного опитувальника в документах Gооglе очінювалися такі симптоми комп'ютерної ииї, як головний біль, біль/дискомфорт в ииї, в плечах, а такожс обізнаність про даний феномен.

Дослідження показало основну роль болю/дискомфорту в плечах серед респондентів, таким чином 59 (66\%) учасників страждають від болю/дискомфорту в плечах в різному ступені із розподілом за статтю: 46жінок (76\%) та 13 чоловіків (43\%). Головний біль в тій чи іниій мірі турбував 56\% респондентів, біль/дискомфорт в ипї відзначили 50\% учасників. В ході дослідження було визначено середній час користування телефоном молодими людьми, який склав 5,3 години.

Лиме третина (32\%) респондентів пов'язували свої симптоми із використанням гаджетів, тож дослідження продемонструвало низьку обізнаність щзодо изьго синдрому серед студентів. Молоді люди не усвідомлюють руйнівного впливу надмірного використання гаджетів на стан здоров'я, зокрема на опорно-руховий апарат.

Приймаючи до уваги вищенаведене, автори вваюсають за необхідне використовувати комплексний підхід з боку сім'і, навчальних закладів та охорони здоров'я в запобіганні розвитку даного синдрому, атакожс включити в навчальні програми курс для ознайомлення студентів з можливими негативними наслідками надмірного використання гаджетів на їхне здоров'я.

Ключові слова: студенти, комп’ютерна шия, неправильна постава

\section{Інформація про авторів}

Ніколенко Свгеній Якович, д. мед. н., проф., зав. кафедри загальної практикисімейної медицини медичного факультету Харківського національного університету імені В. Н. Каразіна, майдан Свободи, 6, м. Харків, Україна, 61022

e-mail: e.nikolenko@karazin.ua https://orcid.org/0000-0002-7653-0644
Адамович Ірина Валеріївна, асистент кафедри загальної практики-сімейної медицини медичного факультету Харківського національного університету імені В. Н. Каразіна, майдан Свободи, 6, м. Харків, Україна, 61022

e-mail: i.adamovich@karazin.ua https://orcid.org/0000-0002-8934-7291
Вовк Кіра Віталївна, к. мед. н., доц. кафедри загальної практики-сімейної медицини медичного факультету Харківського національного університету імені В. Н. Каразіна, майдан Свободи, 6, м. Харків, Україна 61022

e-mail: vovkkira1970@gmail.com https://orcid.org/0000-0003-2971-0842 


\title{
ФЕНОМЕН КОМПЬЮТЕРНОЙ ШЕИ СРЕДИ СТУДЕНТОВ ВЫСШИХ УЧЕБНЫХ ЗАВЕДЕНИЙ
}

\author{
Николенко Е. Я., Адамович И. В., Вовк К. В.
}

Пошта для листування: i.adamovich@karazin.ua

Резюме. В современном мире практически все молодые люди используют гаджеты и теперь большая часть времени использования мобильных телефонов принадлежст дополнительным функииям. К сожалению, молодые люди не учитывают при этом воздействия на опорно-двигательный аппарат. Известно, что длительное использование гаджетов приводит к избыточному сгибанию шейного отдела позвоночника, неправильной осанке и формированию мышечно-тонического синдрома, который сопровождается болью и дискомфортом, то есть синдрому так называемой «компьютерной шеи» (англ. Text nесk). Целью данной статьи была оценка влияния использования гаджетов на формирование болевого синдрома в шее и плечах, а также головной боли среди учашихся высших учебных заведений. В исследовании участвовали 90 респондентов, из них 60 женского пола и 30 мужского пола, возраст участников от 18 до 28 лет. С помощью самостоятельно созданного опросника в Gооglе dосs были оценены симптомы так называемой компьютерной шеи, такие как головная боль, боль/дискомфорт в шее и плечах, а также осведомленность о данном феномене. Исследование показало превалирование такого симптома, как боль/дискомфорт в плечах среди респондентов, 59 (66\%) участников беспокоил этот симптом с таким распределением по полу: 46 женщин (76\%) и 13 мужчин (43\%). Головную боль отметили 56\% участников и 50\% беспокоила боль/дискомфорт в шее. Среднее время использования телефона составило 5,3 часа. Было определено среднее время использования телефона, которое составило 5,3 часа. Было показано превалирование среди респондентов такого симптома как боль/дискомфорт в плечах (66\%), головная боль в той или иной степени беспокоила 56\% респондентов, отметили 50\% участников. Только треть (32\%) респондентов связывали свои симптомь с использованием гаджетов, то есть исследование продемонстрировало низкую осведомленность о данном синдроме среди студентов. Молодье люди не осознают негативное воздействия гаджетов на состояние здоровья, в частности, на состояние костно-мыпечной системы. Принимая во внимание вынесказанное, авторы считают необходимым использовать комплексный подход с участием семьи, образовательных учреждений и здравоохранения в предотвращении развития данного синдрома, а также включить в учебные программы курс для ознакомления студентов с возможными негативными последствиями чрезмерного использования гаджетов на их здоровье.

Ключевые слова: студенты, компьютерная шея, неправильная осанка

Информация об авторах

Николенко Евгений Яковлевич, Адамович Ирина Валерьевна, д. мед. н., проф., зав. кафедры общей ассистент кафедры общей практики практики семейной медицины медицинского факультета Харьковского национального университета имени В. Н. Каразина, пл. Свободы, 6, Харьков, Украина, 61022

e-mail: e.nikolenko@karazin.ua https://orcid.org/0000-0002-7653-0644 ассистент кафедры общей практики
семейной медицины медицинского факультета Харьковского национального университета имени В. Н. Каразина, пл. Свободы, 6, Харьков, Украина, 61022

e-mail: i.adamovich@karazin.ua https://orcid.org/0000-0002-8934-7291
Вовк Кира Витальевна, к. мед. н., доц. кафедры общей практики-семейной медицины медицинского факультета Харьковского национального университета имени В. Н. Каразина, пл.Свободы, 6, Харьков, Украина, 61022 e-mail: ivovkkira1970@gmail.com https://orcid.org/0000-0003-2971-0842

Conflicts of interest: author has no conflict of interest to declare.

Конфлікт інтересів: відсутній.

Конфликт интересов: отсутствует. 


\title{
КЛІНІЧНІ ОСОБЛИВОСТІ РЕАКТИВНИХ АРТРИТІВ У ДІТЕЙ
}

\author{
Панько Н. О., Лебець І. С., Шевченко Н. С., Цюра О. М., Шлєєнкова Г. О., Бутенко А. І.
}

Пошта для листування: panko@karazin.ua

Резюме. До реактивних артритів відносять запальні негнійні захворювання суглобів, щуо розвиваються протягом 2-4 тижнів після кишкової або урогенітальної інфекції внаслідок імунних порушень. Враховуючи неспецифічність клінічних проявів реактивного артриту, його схожість з іншими ревматичними захворюваннями, які мають більш несприятливий перебіг і прогноз, необхідно визнати, щзо дана проблема у дітей залишається актуальною та за багатьма питаннями не розробленою. Мета: визначити клінічні особливості реактивних артритів залежно від етіологічного чинника у дітей на сучасному етапі. Матеріали та методи: У дослідження була залучена 81 дитина з реактивним артритом віком від 2 до 17 років. У процесі уточнення нозологічної форми суглобової патологї̈ використовувались клінічні, загальноприйняті лабораторні та інструментальні дослідження, визначалися специффічні антитіла до хламідій, мікоплазми, ієрсиній, уреаплазми, иитомегаловірусу, вірусу простого герпеса, Спштейн-Бар методом імуноферментного аналізу. Результати: Для реактивного артриту хламідійної етіології характерно ураження крупних та середніх суглобів нижніх кінцівок, яке нерідко супроводжується нетривалою ранковою скутістю і швидким виникненням транзиторних гіпоміатрофій. Рідко можливий розвиток хвороби Рейтера. Мікоплазменому реактивному артриту притаманний дебют з артриту колінних, гомілковостопних, променевозап'ясткових та дрібних суглобів кистей, розвиток бурситів $і$ гіпоміатрофій. Особливістю уреаплазменного реактивного артриту є формування бурситу в області п'ят і тендиніту. Реактивний артрит, який супроводжується підвищеними титрами до АСЛ-О, відрізняється поліморфізмом проявів суглобового синдрому і в певній мірі схожістю з ювенільним ідіопатичним артритом. Реактивний артрит неуточненої етіології мав ряд спільних рис з іниими реактивними артритами та характеризується відносно сприятливим перебігом, тривалим збереженням функиї суглобів і низькою лабораторною активністю. Висновки. Клінічні прояви захворювання та характер його перебігу в певній мірі залежать від етіологічного збудника артриту. Найбільи несприятливими варіантами реактивного артриту є артрити хламідійної та мікоплазменної етіології. Незалежно від збудника, інфекційний фактор може виступати тригером розвитку ювенільного ідіоматичного артриту. Наявність рецидивуючого перебігу реактивного артриту є підставою для повторної диференційної діагностики та рекласифікації на користь ювенільного ідіоматичного артрита, не зважаючи на незначний ступінь запальної активності захворювання та антинуклеарних антитіл і HLAB27 від’'ємність.

Ключові слова: реактивний артрит, дитячий вік, хламідія, мікоплазма, уреаплазма

\section{Інформація про авторів}

Панько Наталія Олександрівна, к. мед. н., доц. кафедри педіатрії № 2 Харківського національного університету імені В. Н. Каразіна, прт Ювілейний, 52a, Харків, Україна, 61153

e-mail: panko@karazin.ua https://orcid.org/0000-0002-32008942

Лебецьь Ірина Степанівна, д. мед. н., проф., кафедри педіатрії Харківського національного університету імені В. Н. Каразіна, пров. наук. співроб. відділення кардіоревматологіі ДУ «Інститут охорони здоров'я дітей та підлітків НАМН», пр-т Ювілейний, 52а, Харків, Україна, 61153

e-mail: cardiorevm.iozdp@gmail.com https://orcid.org/0000-0003-0050-2898 Шевченко Наталя Станіславівна, д. мед. н., зав. кафедрою педіатрії № 2 Харківського національного університету імені В. Н. Каразіна, пр-т Ювілейний, 52а, Харків, Україна, 61153 e-mail: natalia.shevchenko@karazin.ua https://orcid.org/0000-0003-4407-6050

Цюра Оксана Миколаївна, к. мед. н, доцент кафедри педіатрії № 2 Харківського національного університету імені В. Н. Каразіна, пртЮвілейний, 52а, Харків, Україна, 61153 e-mail: cyra@karazin.ua
https://orcid.org/0000-0001-8245-015X Шлєєнкова Ганна Олександрівна, к. мед. н., асистент кафедри педіатрії № 2 Харківського національного університету імені В.Н. Каразіна, пр-т Ювілейний, 52а, Харків, Україна, 61153 e-mail: shleenkova@karazin.ua https://orcid.org/0000-0001-9775-4324 Бутенко Антоніна Ігорівна, к. мед. наук, доц. кафедри педіатрії № 2 Харківського національного університету імені В. Н. Каразіна, пр-т Ювілейний, 52a, Харків, Україна, 61153

e-mail: antoninabutenko@karazin.ua https://orcid.org/0000-0002-0716-496X

\section{Ветуп}

Згідно сучасним поглядам до реактивних артритів (РеА) відносять запальні негнійні захворювання суглобів, що розвиваються протягом 2-4 тижнів після кишкової або урогенітальної інфекції внаслідок імунних порушень. В дитячому віці іноді зазначається, що розвиток РеА можливий після респіраторної інфекції. Найбільш поширеними етіологічними 
чинниками РеА вважаються ентеробактерії (Yersinia enterocolitica, Yersinia pseudotuberculosis, Salmonella enteritidis, Salmonella typhimurium, Shigella flexneri, Shigella sonnei, Shigella Newcastle, Campylobacter jejuni), мікроорганізми, що спричиняють гостру або персистуючу урогенітальну інфекцію (Chlamydia trachomatis, Ureaplasma urealitica та інші). Серед збудників інфекцій респіраторного тракту значна роль у розвиту РеА належить Mycoplasma pneumoniae та Chlamydophila pneumonia. $€$ дані про зв'язок РеA 3 кишковою інфекцією, асоційованою зі збудником Clostridium difficile i деякими паразитарними інфекціями $[1,2,3]$.

У ряді досліджень продемонстровано, що клінічна картина PeA у дітей різноманітна: від малосимптомного моноартриту до важкого поліартриту із системними проявами; та, як правило, залежить від особливостей етіологічного чинника $[1,5,9,13]$. Деякими авторами зазначається, що РеA, асоційований 3 внутрішньоклітинною інфекцією, у тому числі й хламідійною, характеризується несиметричним запаленням переважно у суглобах нижніх кінцівок (особливо пальців стоп) з ентезопатіями та бурситами п'ят. Можливе ураження органу зору, шкіри і слизових оболонок, серцевосудинної системи у вигляді: «уретрит - артрит кон'юнктивіт», які зазвичай складають класичну тріаду цієї патології, що відома як хвороба Рейтера $[3,10]$. Також певна роль у розвитку РеА у дітей відводиться інфекціям носоглотки, в тому числі хронічному тонзиліту, фарингіту, гаймориту. Постстрептококовому артриту, який зазвичай виникає на тлі або через 1-2 тижні після перенесеної стрептококової інфекції верхніх дихальних шляхів, притаманне одночасне залучення у процес переважно середніх і великих суглобів у межах моно- або олігоартриту, відсутність ознак органічного ураження серця та інших внутрішніх органів, незначні відхилення 3 боку лабораторних показників $[10,12]$.

Для встановлення діагнозу РеА на наш час частіше за все використовуються критерії Американської ревматологічної асоціації, які включають наступні ознаки: серонегативний асиметричний артрит, наявність уретриту, цервіциту, діареї, запальні зміни з боку органу зору, ураження шкіри або слизових оболонок.
Але вони розроблені і орієнтовані на дорослих пацієнтів [5]. В педіатричній практиці РеА частіше $€$ діагнозом виключення, коли при наявності синовіту використовується термін ранній артрит та проводиться диференційна діагностика 3 більш серйозними артритами 3 хронічним перебігом, такими як ювенільний ідіопатичний артрит (ЮІА).

Враховуючи неспецифічність клінічних проявів РеА, його схожість 3 іншими ревматичними захворюваннями, які теж супроводжуються артритом, але мають більш несприятливий перебіг i прогноз, необхідно визнати, що проблема РеА у дітей залишається актуальною та за багатьма питаннями не вирішеною.

Мета: визначити клінічні особливості реактивних артритів залежно від етіологічного чинника у дітей на сучасному етапі.

\section{Матеріали та методи}

У дослідження було залучено 81 дитина 3 реактивним артритом віком від 2 до 17 років, що знаходилася на лікуванні у клініці Ду "ОЗДП НАМН". Групу контролю склали 12 практично здорових дітей, ідентичних за віком та статтю 3 основною групою. Для встановлення діагнозу керувалися Міжнародною класифікацією хвороб $\mathrm{X}$ перегляду, протоколами діагностики та лікування кардіоревматологічних хвороб у дітей (наказ MO3 № 362 від 2005) та уніфікованим клінічним протоколом медичної допомоги дітям, хворим на ювенільний артрит (наказ МО3 № 832 від 22.10.2012). Обстеження пацієнтів включало стандартне клінічне дослідження, УЗД суглобів, визначення лабораторних показників, в тому числі титру антинуклеарних антитіл (АНА) та наявності гену HLAB27, позитивність спектру антитіл до хламідій, мікоплазм, ієрсиній, уреаплазми, цитомегаловірусу, вірусу простого герпеса, вірусу Єпштейн-Бар методом імуноферментного аналізу (ІФА). Критерієм включення пацієнтів у дослідження була негативність за ANA та ревматоїдним фактором. Статистичну обробку матеріалу проведено за допомогою пакету програм Statistica+ для Windows 3 використанням частотного аналізу, критеріїв Стьюдента - Фішера, Мана-Уітні та критерію достовірності результатів $(\mathrm{p}<0,05)$. 


\section{Результати та їх обговорення}

Серед дітей основної групи осіб жіночої статі було 43 (53,09\%), чоловічої - 38 (46,91 \%). Вік хворих на момент обстеження був від 2 до 17 років та в середньому склав $(8,32 \pm 1,0)$ роки. $\mathrm{PeA}$ виник вперше у $38,27 \%$ дітей, у решти $(61,73 \%)$ відмічено рецидивуючий характер перебігу захворювання. Вік дебюту захворювання коливався від 2 до 17 років і в середньому складав $(8,1 \pm 1,3)$ років.

Вивчення анамнестичних даних виявило наявність можливих тригерних чинників: у $39,51 \%$ пацієнтів початку РеА передувала гостра респіраторна інфекція, 17,28 \% зазначали травму, як провокуючий фактор, у 4,94 \% випадків мала місце діарея, у 2,47 \% осіб - вакцинація та 7,41 \% дітей зазначали інші причини. Тригерний чинник був відсутній у $28,4 \%$ дітей.

За кількістю уражених суглобів у дебюті PeA характеризувався переважно моноартритом $85,19 \%$, рідко визначався олігоартрит $14,81 \%$, хворі $з$ поліартритом були відсутні.

У більшості дітей РеА старт захворювання був представлений ураженням колінних $(64,20 \%)$ та гомілковостопних суглобів $(11,11 \%)$. Коксит, як перший прояв захворювання, спостерігався у 19,75 \% осіб. Майже у половини хворих, у яких РеA розпочався з ураження кульшових суглобів, у наступні 6 місяців при відсутності адекватної терапії мало місце прогресування хвороби і у $1 / 43$ них сформувався поліартрит. Тільки у окремих осіб РеА дебютував 3 артриту променевозап'ясткових суглобів $(2,47 \%)$, що було підставою для диференційної діагностики його з ЮІА. В поодиноких випадках $(1,23 \%)$ у дітей 3 РеА першими уражались плечові та дрібні суглоби стоп.

У більшості (66,7 \%) пацієнтів з РеА при контролі через пів року визначено стійку ремісію. Рецидивування процесу та тенденція до хронічного перебігу спостерігались у 33,3 \% осіб. У цих дітей діагноз РеА було переглянуто на користь ЮІА та призначено базисне лікування.

При оцінці ролі етіологічних чинників РеА визначено наявність мікоплазменної інфекції у 23,46 \% пацієнтів, уреаплазменної - у 13,58 \% та хламідійної - у 9,89 \% досліджуваних.
Підвищені титри АСЛ-О мали 28,40 \% осіб. У хворих на РеА мала місце персистенція вірусів. $\mathrm{У}$ половини пацієнтів (52,00 \%) виявлено підвищені титри антитіл до вірусу простого герпесу I i II типу, у 32,00\% осіб - до цитомегаловірусу i у $23,81 \%$ - до вірусу Епштейн-Барр. Сполучення внутріклітинної бактеріальної інфекції з одним або декількома iз зазначених вірусів визначено у $28,00 \%$ пацієнтів. В той же час, у 24,69 \% етіологія РеА залишилася не уточненою.

Артрит хламідійної етіології характеризувався дебютом із асиметричного ураження колінних $(75,00 \%)$, кульшових $(12,50 \%)$ та променевозап'ясткових (12,5\%) суглобів; формуванням олігоартриту у $62,50 \%$ осіб; відсутністю бурситів та ентеритів; наявністю нетривалої ранкової скутості (15-20 хвилин); незначними змінами лабораторних показників (ШОЕ та СРБ залишалися в межах норми у 87,50 \% та 75,00 \% хворих відповідно, рівні гострофазових протеїнів підвищувались лише у $12,50 \quad \%$ дітей); відсутністю рентгенологічних змін $(87,5 \%$ та рецидивуючим перебігом (75,00\%) (Табл.1). У $12,50 \%$ хворих визначалися увеїт і уретрит, що склало класичну тріаду симптомів хвороби Рейтера.

РeA мікоплазменної природи характеризувався стартом з ураження колінних суглобів $(68,42 \%)$, гомілковостопних $(10,53 \%)$ та в поодиноких випадках - кульшових, плечових, променевозап'ясткових суглобів; більш швидким прогресуванням (протягом $3 \mathrm{x}$ місяців) 3 формуванням оліго- $(42,11 \%)$ та поліартриту $(21,05 \%)$; залученням плечових суглобів (15,79\%); формуванням бурситів $(10,53 \%)$; наявністю скарг загального характеру (незадовільне самопочуття $(10,53 \%)$, загальна м'язова слабкість $(5,26 \%)$, підвищена втомлюваність (5,26 \%), труднощі під час ходіння $(89,47 \%))$; скаргами на ранкову скутість $(57,89 \%)$ та артралгії протягом дня $(68,42 \%)$. Наявність більш тривалої ранкової скутості у хворих значно ускладнювало диференційну діагностику з ЮІА, особливо, при наявності поліартриту. У дітей 3 мікоплазменною етіологією РеА відмічено відсутність лабораторної активності запального процесу за ШОЕ - у 73,68 \%, за СРБ - у 78,95 \%; за гостро фазовими 
показниками - у 73,68 \%. Разом 3 тим, рецидивуючий перебіг мали 63,16 \% пацієнтів.

РеА уреаплазменної етіології мав наступні специфічні риси: старт з запалення у колінних $(72,73 \%), \quad$ гомілковостопних $(27,27 \%)$ суглобів; подальше прогресування 3 формуванням олігоартриту $(36,36 \%)$ та поліартриту (9,09 \%); відсутність загальних скарг; наявність тугорухливості суглобів та артралгій $(54,55$ \%), переважно короткочасної ранкової скутості $(54,55 \%)$; відсутність рентгенологічних змін $(90,91 \%)$. Особливістю уреаплазменного РеA було формування бурситу в області п'ят $(18,18$ \%) та швидкий розвиток функціональної недостатності суглобів до II ступеня (36,36 \%). Що стосується показників гострої фази запалення, то вони підвищувалися незначно: рівень сіромукоїду та сіалових кислот - у 36,36 \% дітей, СРБ - у $27,27 \%$, ШОЕ - у 18,18\% осіб.

Таблиця 1. Розподіл клінічних проявів РеА за частотою в залежності від етіологічного чинника, $(M \pm m) \%$

\begin{tabular}{|c|c|c|c|c|c|}
\hline \multirow[t]{2}{*}{ Клінічна ознака } & \multicolumn{5}{|c|}{ Етіологічний чинник } \\
\hline & $\begin{array}{c}\text { Хламідія } \\
\mathrm{n}=8 \\
\end{array}$ & $\begin{array}{c}\text { Мікоплазма } \\
\text { n = } 19 \\
\end{array}$ & $\begin{array}{c}\text { Уреаплазма } \\
\mathrm{n}=11 \\
\end{array}$ & $\begin{array}{c}\text { АСЛ-О - } \\
\text { асоційо-ваний } \\
\mathrm{n}=23 \\
\end{array}$ & $\begin{array}{c}\text { Неуточне-ний } \\
\text { n }=20 \\
\end{array}$ \\
\hline \multicolumn{6}{|c|}{ Ураження суглобів в дебюті захворювання } \\
\hline $\begin{array}{l}\text { Колінні } \\
\text { Гомілковостопні } \\
\text { Кульшові } \\
\text { Плечові } \\
\text { Ліктьові } \\
\text { Променево-запясткові } \\
\text { Дрібні суглоби кистей } \\
\text { Дрібні суглоби стоп } \\
\text { Бурсит, ентезит }\end{array}$ & $\begin{aligned} 75,00 & \pm 15,31 \\
12,50 & \pm 11,69 \\
12,50 & \pm 11,69 \\
& - \\
& - \\
12,50 & \pm 11,69 \\
& - \\
& - \\
& -\end{aligned}$ & $\begin{array}{c}68,42 \pm 10,66 \\
10,53 \pm 7,04 \\
5,26 \pm 5,12 \\
5,26 \pm 5,12 \\
- \\
5,26 \pm 5,12 \\
- \\
- \\
10,53 \pm 7,04\end{array}$ & $\begin{aligned} 72,73 & \pm 13,43 \\
27,27 & \pm 13,43 \\
& - \\
- & - \\
- & \\
- & - \\
18,18 & \pm 11,63\end{aligned}$ & $\begin{aligned} 47,83 & \pm 10,42 \\
17,39 & \pm 7,90 \\
21,74 & \pm 8,60 \\
- & \\
4,35 & \pm 4,25 \\
8,70 & \pm 5,88 \\
- & - \\
- & \\
21,74 & \pm 8,60\end{aligned}$ & $\begin{aligned} 63,27 & \pm 6,89 \\
6,12 & \pm 3,42 \\
28,57 & \pm 6,45 \\
- & - \\
2,04 & \pm 2,02 \\
- & - \\
12,24 & \pm 4,68\end{aligned}$ \\
\hline \multicolumn{6}{|c|}{ Прогресування перебігу у формі: } \\
\hline $\begin{array}{l}\text { Моноартриту } \\
\text { Олігоартриту } \\
\text { Поліартриту } \\
\end{array}$ & $\begin{array}{l}25,00 \pm 15,31 \\
62,50 \pm 17,12 \\
25,00 \pm 15,31 \\
\end{array}$ & $\begin{array}{c}36,84 \pm 11,07 \\
42,11 \pm 11,33 \\
21,05 \pm 9,35 \\
\end{array}$ & $\begin{array}{c}54,55 \pm 15,01 \\
36,36 \pm 14,50 \\
9,09 \pm 8,67 \\
\end{array}$ & $\begin{array}{c}21,74 \pm 8,60 \\
60,87 \pm 10,18 \\
17,39 \pm 7,90 \\
\end{array}$ & $\begin{array}{l}48,98 \pm 7,14 \\
38,78 \pm 6,96 \\
12,24 \pm 4,68 \\
\end{array}$ \\
\hline \multicolumn{6}{|c|}{ Позасуглобові ураження: } \\
\hline $\begin{array}{l}\text { Загальні скарги } \\
\text { Увеїт } \\
\text { Уретрит }\end{array}$ & $\begin{array}{l}12,50 \pm 11,69 \\
12,50 \pm 11,69 \\
12,50 \pm 11,69\end{array}$ & $\begin{array}{c}10,53 \pm 7,04 \\
- \\
-\end{array}$ & $\begin{array}{l}- \\
- \\
-\end{array}$ & $\begin{array}{l}- \\
- \\
-\end{array}$ & $\begin{aligned} 8,16 & \pm 3,91 \\
& - \\
- & \end{aligned}$ \\
\hline \multicolumn{6}{|c|}{ Наявність } \\
\hline $\begin{array}{l}\text { Ранкової скутості } \\
\text { Рецидивуючий перебіг }\end{array}$ & $\begin{array}{l}75,00 \pm 15,31 \\
75,00 \pm 15,31\end{array}$ & $\begin{array}{l}57,89 \pm 11,33 \\
63,16 \pm 11,07\end{array}$ & $\begin{array}{l}54,55 \pm 15,01 \\
27,27 \pm 13,43\end{array}$ & $\begin{array}{l}39,13 \pm 9,59 \\
17,39 \pm 7,90\end{array}$ & $\begin{array}{c}32,65 \pm 6,70 \\
6,12 \pm 3,42\end{array}$ \\
\hline \multicolumn{6}{|c|}{ Підвищення лабораторних показників } \\
\hline $\begin{array}{l}\text { ШОЕ } \\
\text { СРБ } \\
\text { Сіалові кислоти } \\
\text { Серомукоїд } \\
\text { Глікопротеїди }\end{array}$ & $\begin{array}{l}12,50 \pm 11,69 \\
25,00 \pm 15,31 \\
12,50 \pm 11,69 \\
12,50 \pm 11,69 \\
12,50 \pm 11,69\end{array}$ & $\begin{array}{c}26,32 \pm 10,10 \\
21,05 \pm 9,354 \\
7,37 \pm 11,45 \\
36,84 \pm 11,07 \\
26,32 \pm 10,10\end{array}$ & $\begin{array}{c}18,18 \pm 11,63 \\
27,27 \pm 13,43 \\
36,36 \pm 14,50 \\
36,36 \pm 14,50 \\
9,09 \pm 8,67\end{array}$ & $\begin{array}{c}17,39 \pm 7,90 \\
17,39 \pm 7,90 \\
8,70 \pm 5,88 \\
8,70 \pm 5,88 \\
8,70 \pm 5,88\end{array}$ & $\begin{array}{c}6,12 \pm 3,42 \\
12,24 \pm 4,68 \\
12,24 \pm 4,68 \\
6,12 \pm 3,42 \\
10,20 \pm 4,32\end{array}$ \\
\hline
\end{tabular}

У групі дітей з РеА на тлі високих показників АСЛ-О дебют захворювання відбувався з артриту колінних $(47,83 \%)$, кульшових $(21,74 \%)$, гомілковостопних $\quad(17,39 \%)$, променевозап'ясткових $(8,70 \%)$ та ліктьових (4,35 \%) суглобів. Формування олігоартиту визначалося у 60,87 \% дітей, а поліартиту - у
17,39 \%. Ранкова скутість відмічалась у 39,13\% дітей, артралгії протягом дня у - 60,87 \% досліджуваних. При АСЛ-О позитивному артриті не відмічалось порушення функції суглобів $(91,30 \%)$, на відміну від уреаплазменних $(63,64 \% ; \mathrm{p}<0,01)$ та хламідійних РеА (37,5\%; $\mathrm{p}<0,05)$. Рентгенологічні зміни, як правило, були 
відсутні, а зсуви у лабораторних показниках не мали статистичних відмінностей від артритів іншого походження.

У випадках неуточненої природи РеА відмічено більш часте залучення кульшових (28,57 \%) суглобів, прогресування з формуванням олігоартриту $(38,78 \%$ ), менша частота скарг на ранкову скутість (32,65 \%), ніж при хламідійній (p < 0,001) або мікоплазменній $(\mathrm{p}<0,05)$ природі РеА; менша частота розвитку бурситів $(12,24 \%)$ та регіональної м'язової гіпотрофії (36,73 \%) порівняно 3 PeA уреаплазменної етіології $(\mathrm{p}<0,001)$.

\section{Обговорення результатів}

Згідно результатам нашого дослідження, більшість РеА при своєчасній адекватній терапії закінчується одужанням, що співпадає 3 даними авторів з Свропейських та Азіатських країн [9, 11]. Визначено, що для РеА хламідійної етіології було характерним ураження крупних та середніх суглобів нижніх кінцівок у вигляді олігоартриту, яке нерідко супроводжувалося нетривалою ранковою скутістю і швидким виникненням транзиторних регіональних гіпоміатрофій. Можливе було підвищення лабораторних показників гострої фази запалення та виникнення мінімальних патологічних змін на рентгенограмах. Дана клінічна картина у певній мірі відповідала опису хламідійних артритів у дорослих [3, 8, 9, 14]. Не виключено розвиток хвороби Рейтера, але в дитячому віці такий варіант РеА зустрічається рідко, що також неодноразово зазначалось іншими авторами $[1,7$, 11].

Мікоплазменому РеА притаманні були у дебюті ураження не тільки колінних, гомілковостопних, а й променевозап'ясткових та дрібних суглобів кистей, розвиток бурситів i регіональних гіпоміатрофій, що значно ускладнювало диференційну діагностику з ЮІА. Популяційне когортне дослідження у Тайвані, у тому числі дітей, від 2019 року, продемонструвало, що хворі 3 позитивними титрами до Mycoplasma Pneumonia мали вищий ризик розвитку ревматоїдного артриту, ніж серонегативні пацієнти, особливо особи віком до 19 та після 65 років [4]. На жаль, в Україні не проводилось жодних когортних досліджень 3 приводу ролі мікоплазми у розвитку ЮІА, тому отримані нами результати $\epsilon$ певною мірою унікальними.

Згідно літературним даним PeA уреаплазменної етіології відносно рідко зустрічається в педіатричній практиці ( $\approx 9 \%$ ), тому даних $з$ приводу особливостей клінічного перебігу цих артритів у дітей обмаль $[7,12]$. У нашому дослідженні відмічено, що особливістю уреаплазменного РеА було на тлі асиметричного артриту суглобів нижніх кінцівок формування бурситу і тендиніту в області п'ят, відсутність, навіть при затяжному характері перебігу, рентгенологічних змін та невиражена лабораторна активність. Схожі особливості перебігу уреаплазменного РеА мали місце серед дорослих $[9,13,14]$.

Прийнято вважати, що РеA, який супроводжується підвищеними титрами АСЛ-О, в першу чергу потребує проведення диференційної діагностики 3 гострою ревматичною лихоманкою $[6,7,12]$, що ретельно було зроблено відносно хворих, залучених до нашого дослідження. При цьому визначено, АСЛ- $\mathrm{O}$ асоційований РеA відрізнявся поліморфізмом проявів суглобового синдрому і, в певній мірі, схожістю з ЮІА, що ускладнювало диференційну діагностику. Разом 3 тим, він характеризувався відсутністю загальних скарг, ранкової скутості, регіональних гіпоміатрофій, відхилень стосовно лабораторних показників гострої фази запалення, рентгенологічних змін або їх прогресування.

РеА неуточненої етіології мав ряд спільних рис 3 іншими РеА та характеризувався відносно доброякісним перебігом, тривалим збереженням функції суглобів і низькою лабораторною активністю.

Зважаючи на те, що у 33,3 \% осіб 3 PeA спостерігалась тенденція до хронічного перебігу 3 частими рецидивами, будь-який РеА з затяжним або рецидивуючим перебігом, незалежно від наявності етіологічного чинника, повинен розглядатися за критеріями діагностики ЮІА на якомога ранніх строках розвитку запального процесу.

\section{Висновки}

1. РеА у дітей $є$ неоднорідною групою. Клінічні прояви захворювання та характер його перебігу в певній мірі залежить від етіологічного збудника артриту. 
2. Найбільш несприятливими варіантами PeA $\epsilon$ артрити хламідійної та мікоплазменної етіології. Незалежно від збудника, інфекційний фактор може виступати тригером розвитку ЮІА.

3. Наявність рецидивуючого перебігу РеА, прогресування 3 формуванням оліго- та поліартритичного ураження суглобів $є$ підставою для повторної диференційної діагностики та рекласифікації на користь ЮІА, не зважаючи на незначний ступінь запальної активності захворювання та АНА і НLAB27 від'ємність.

\section{Список літератури}

1. Бойко ЯЄ Диференціальна діагностика артритів у дітей. Сучасна педіатрія. 2019. №5. С. 112-122. doi 10.15574/SP.2019.101.112

2. Ajene AN, Fischer Walker CL, Black RE. Enteric pathogens and reactive arthritis: a systematic review of Campylobacter, salmonella and Shigella-associated reactive arthritis. J Health Popul Nutr. 2013;31(3):299-307. doi:10.3329/jhpn.v31i3.16515.

3. Carter JD, Hudson AP. Recent advances and future directions in understanding and treating Chlamydia-induced reactive arthritis. Expert Rev Clin Immunol. 2016 Sep 20. P. 1-10. [ISSN: 1744-8409].

4. Chu K-A, Chen W, Hsu CY, Hung Y-M, Wei JC-C (2019) Increased risk of rheumatoid arthritis among patients with Mycoplasma pneumonia: A nationwide populationbased cohort study in Taiwan. PLoS ONE 14(1): e0210750. https://doi.org/10.1371/journal.pone.0210750.

5. Garcia-Kutzbach A, Chacon-Suchite J, GarciaFerrer H, Iraheta I. Reactive arthritis: update 2018. Clin Rheumatol. 2018 Apr. Vol. 37 (4). P. 869-874. https://doi.org/10.1007/s10067-018-4022-5.

6. Hayes KM, Hayes RJP, Turk MA, Pope JE. Evolving patterns of reactive arthritis. Clin Rheumatol. 2019 Aug;38(8):2083-2088. doi: 10.1007/s10067-019-04522-4. Epub 2019 Mar 27. PMID: 30919146.

7. Janice John, Latha Chandran. Arthritis in Children and Adolescents. Pediatrics in Review. 2011; 32 (11) 470480; DOI: https://doi.org/10.1542/pir.32-11-470.

8. Lahu A, Bajraktari IH, Lahu S, et al. The source of infection and the most frequent causes of reactive arthritis in Kosovo. Mater Sociomed. 2016;28(3):201-204. doi:10.5455/msm.2016.28.201-204.

9. Megha Sharma, Susmita Sharma, Aman Sharma, Kusum Sharma. (2020). Chlamydia Trachomatis Associated Reactive Arthritis: A Urinary PCR Based Study. Indian Dermatol Online J. 2020 Jan-Feb; 11(1): 21-24. doi: 10.4103/idoj.IDOJ_410_19.

10. Petty RE, Laxer RM, Lindsley CB, Wedderburn LR. (2015). Textbook of pediatric rheumatology, 7th edn. Philadelphia: Saunders: 739.

11. Plesca DA, Luminos M, Spatariu L, Stefanescu M, Cinteza E, Balgradean M. Postinfectious arthritis in pediatric practice. Maedica (Bucur). 2013;8(2):164-169. PMID: 24371480.
12. Schmitt SK. Reactive Arthritis. Infect Dis Clin North Am. 2017. Vol. 31, Issu 2. P. 265-277. https://doi.org/10.1016/j.idc.2017.01.002.

13. Selmi C, Gershwin ME. Diagnosis and classification of reactive arthritis. Autoimmun Rev. 2014 $\begin{array}{lllll}\text { Apr-May. } & \text { Vol. } & 13 & \text { (4-5). } & \text { P. 546-9. }\end{array}$ https://doi.org/10.1016/j.autrev.2014.01.005.

14. Zeidler, H., Hudson, A.P. Chlamydia-Induced Reactive Arthritis: Disappearing Entity or Lack of Research?. Curr Rheumatol Rep 21, 63 (2019). https://doi.org/10.1007/s11926-019-0863-4.

\section{References}

1. Boyko YaE. Differential diagnosis of arthritis in children. Modern Pediatrics.Ukraine. 2019.5(101): 112-122. doi 10.15574/SP.2019.101.112 [in Ukrainian].

2. Ajene AN, Fischer Walker CL, Black RE. Enteric pathogens and reactive arthritis: a systematic review of Campylobacter, salmonella and Shigella-associated reactive arthritis. J Health Popul Nutr. 2013;31(3):299-307. doi:10.3329/jhpn.v31i3.16515.

3. Carter JD, Hudson AP. Recent advances and future directions in understanding and treating Chlamydia-induced reactive arthritis. Expert Rev Clin Immunol. 2016 Sep 20. P. 1-10. [ISSN: 1744-8409].

4. Chu K-A, Chen W, Hsu CY, Hung Y-M, Wei JC-C (2019) Increased risk of rheumatoid arthritis among patients with Mycoplasma pneumonia: A nationwide populationbased cohort study in Taiwan. PLoS ONE 14(1): e0210750. https://doi.org/10.1371/journal.pone.0210750.

5. Garcia-Kutzbach A, Chacon-Suchite J, GarciaFerrer H, Iraheta I. Reactive arthritis: update 2018. Clin Rheumatol. 2018 Apr. Vol. 37 (4). P. 869-874. https://doi.org/10.1007/s10067-018-4022-5.

6. Hayes KM, Hayes RJP, Turk MA, Pope JE. Evolving patterns of reactive arthritis. Clin Rheumatol. 2019 Aug;38(8):2083-2088. doi: 10.1007/s10067-019-04522-4. Epub 2019 Mar 27. PMID: 30919146.

7. Janice John, Latha Chandran. Arthritis in Children and Adolescents. Pediatrics in Review. 2011; 32 (11) 470480; DOI: https://doi.org/10.1542/pir.32-11-470.

8. Lahu A, Bajraktari IH, Lahu S, et al. The source of infection and the most frequent causes of reactive arthritis in Kosovo. Mater Sociomed. 2016;28(3):201-204. doi:10.5455/msm.2016.28.201-204.

9. Megha Sharma, Susmita Sharma, Aman Sharma, Kusum Sharma. (2020). Chlamydia Trachomatis Associated Reactive Arthritis: A Urinary PCR Based Study. Indian Dermatol Online J. 2020 Jan-Feb; 11(1): 21-24. doi: 10.4103/idoj.IDOJ_410_19.

10. Petty RE, Laxer RM, Lindsley CB, Wedderburn LR. (2015). Textbook of pediatric rheumatology, 7th edn. Philadelphia: Saunders: 739.

11. Plesca DA, Luminos M, Spatariu L, Stefanescu M, Cinteza E, Balgradean M. Postinfectious arthritis in pediatric practice. Maedica (Bucur). 2013;8(2):164-169. PMID: 24371480.

12. Schmitt SK. Reactive Arthritis. Infect Dis Clin North Am. 2017. Vol. 31, Issu 2. P. 265-277. https://doi.org/10.1016/j.idc.2017.01.002.

13. Selmi C, Gershwin ME. Diagnosis and classification of reactive arthritis. Autoimmun Rev. 2014 
Apr-May. $\quad$ Vol. $13 \quad$ (4-5). $\quad$ P. $\quad$ 546-9. Research?. Curr Rheumatol Rep 21, 63 (2019). https://doi.org/10.1016/j.autrev.2014.01.005.

14. Zeidler, H., Hudson, A.P. Chlamydia-Induced

Reactive Arthritis: Disappearing Entity or Lack of

\title{
CLINICAL FEATURES OF REACTIVE ARTHRITIS IN CHILDREN
}

\author{
Panko Nataliya, Lebets Iryna, Shevchenko Natala, Tsiura Oksana, \\ Shlieienkova Hanna, Butenko Antonina
}

Mail for correspondence: Panko@karazin.ua Summary. Reactive arthritis includes inflammatory non-purulent diseases of the joints that develop within 2-4 weeks after intestinal or urogenital infection due to immune disorders. Given the nonspecificity of the clinical manifestations of reactive arthritis, its similarity to other rheumatic diseases, which have a more unfavorable course and prognosis, it must be recognized that the problem of reactive arthritis in children remains relevant and on many issues not developed. Objective: this is to identify the characteristics of the debut and currents of reactive arthritis in accordance to etiology in children today. Materials and methods: There were observed 81 children with a reactive arthritis in the age of from 2 till 17 years have been examined. During specification the nosology of articular pathology were used clinical, laboratory and instrumental investigations, identified specific antibodies to Chlamydia, Mycoplasma, Iersiniya, Ureaplazma, Citomegalovirus, Herpes simplex virus, Epstein-Bar's virus by ELISA. Results: For reactive arthritis chlamydial etiology characterized by loss of large and medium-sized joints of the lower limbs, which often is accompanied by a brief morning stiffness and rapid emergence of transient regional hypotrophy of muscles. Feature ureaplazmial reactive arthritis is the formation of bursitis in the heel and tendinitis. Reactive arthritis, which is accompanied by elevated titers to ASL-O, had different polymorphisms of articular manifestations of the syndrome and to a certain degree of similarity with juvenile rheumatoid arthritis. Reactive arthritis of not specified etiology has a number of the general features with others reactive arthritis and it is characterized by rather good-quality current, long conservation of function of joints and low laboratory activity. Conclusions: The clinical manifestation of the disease and the nature of its course to some extent depend on the etiological pathogen of arthritis. The most unfavorable variants of reactive arthritis are arthritides caused by Chlamydia and Mycoplasma. Regardless of the pathogen, the infectious factor can be assessed as a trigger for the development of juvenile rheumatoid arthritis. The presence of recurrent reactive arthritis is the basis for re-differential diagnosis and reclassification of reactive arthritis in favor of juvenile rheumatoid arthritis, despite the low degree of inflammatory activity of the disease and ANA and HLAB27 negativity.

Key words: Reactive arthritis, childhood age, Chlamidia, Mycoplasma, Ureaplasma

Information about author

Panko Nataliya, MD, PhD, Assoc. Prof. of the department of Pediatrics \# 2 of V. N. Karazin Kharkiv National University, Juvilejnyi Avenue, 52a, Kharkov, Ukraine, 61153

e-mail:panko@karazin.ua

https://orcid.org/0000-0002-3200-8942

Lebets Iryna, MD, PhD, Full Prof. of the department of Pediatrics of V. N. Karazin Kharkiv National University, the leading researcher of the Department of Cardiorheumatology of SE "Institute of children and adolescences health care of National Academy of Medical Science" Juvilejnyi Avenue, 52a, Kharkov, Ukraine, 61153 e-mail: cardiorevm.iozdp@gmail.com https://orcid.org/0000-0003-0050-2898

Shevchenko Natalia, MD, PhD, Head of the Department of Pediatrics \# 2 of V. N. Karazin Kharkiv National University, the leading researcher of Department of Cardiorheumatology of SI "Institute of children and adolescences health care of National Academy of Medical Science", Juvilejnyi Avenue, 52a, Kharkov, Ukraine, 61153

Tsiura Oksana, $\mathrm{MD}, \mathrm{PhD}$, Assoc. Prof. of the department of Pediatrics \# 2 of V. N. Karazin Kharkiv National University, Juvilejnyi Avenue, 52a, Kharkov, Ukraine, 61153

e-mail: cyra@karazin.ua
https://orcid.org/0000-0001-8245-015X

Shlieienkova Hanna, MD, PhD, Assoc. Prof. of the department of Pediatrics \# 2 of V. N. Karazin Kharkiv National University, Juvilejnyi Avenue, 52a, Kharkov, Ukraine, 61153

e-mail: shleenkova@karazin.ua https://orcid.org/0000-0001-9775-4324

Butenko Antonina, MD, PhD, Assoc. Prof. of the department of Pediatrics \#2 of V. N. Karazin Kharkiv National University, Juvilejnyi Avenue, 52a, Kharkov, Ukraine, 61153

e-mail: antoninabutenko@karazin.ua https://orcid.org/0000-0002-0716-496X

\section{КЛИНИЧЕСКИЕ ОСОБЕННОСТИ РЕАКТИВНЫХ АРТРИТОВ У ДЕТЕЙ}

\author{
Панько Н. А., Лебец И. С., Шевченко Н. С., Цюра О. Н., Шлєєнкова А. А., Бутенко А. И.
}

Почта для переписки: panko@karazin.ua

Резюме. К реактивным артритам относят воспалительные негнойные заболевания суставов, развивающиеся 8 течение 2-4 недель после кишечной или урогенитальной инфекции вследствие иммунньх нарушений. Учитывая неспецифичность клинических проявлений реактивного артрита, его сходство с другими ревматическими заболеваниями, которые имеют более неблагоприятное течение и прогноз, необходимо признать, что проблема реактивных артритов у детей остается актуальной и по многим вопросам не разработанной. Цель: определить клинические особенности реактивных артритов в зависимости от этиологического агента у детей на современном этапе. Материалы и методы: В исследование был вовлечен 81 ребенок с реактивным артритом 8 
возрасте от 2 до 17 лет. В процессе уточнения нозологической формы суставной патологии использовались клинические, общепринятые лабораторные и инструментальные исследования, определялись специифические антитела к хламидийной, микоплазменной, иерсинеозной, уреаплазменной инфекииям, иитомегаловирусу, вирусу простого герпеса, Епштейн-Бар методом иммуноферментного анализа. Результаты: для реактивного артрита хламидийной этиологии характерно поражение крупных и средних суставов нижних конечностей, которое нередко сопровождается непродолжительной утренней скованностью и быстрым возникновением транзиторных гипомиатрофий. Особенностью уреаплазменного артрита является формирование бурсита в области пяток и тендинита. Реактивный артрит, который сопровождается повышенными титрами к АСЛ-О, отличается полиморфизмом проявлений суставного синдрома и в определенной степени сходством с ювенильньлм ревматоидным артритом. Реактивный артрит неуточненной этиологии имеет ряд общих черт с другими реактивными артритами и характеризуется относительно доброкачественным течением, длительным сохранением функции суставов и низкой лабораторной активностью. Частота рецидивов реактивных артритов возрастает с увеличением продолжительности болезни. Выводы. Клиническая картина заболевания и характер его течения в определенной степени зависят от этиологического возбудителя артрита. Наиболее неблагоприятными вариантами реактивного артрита являются артриты хламидийной и микоплазменной этиологии. Независимо от возбудителя, инфекционный фактор может выступать в качестве триггера развития ювенильного ревматоидного артрита. Наличие рецедивирующего течения реактивного артрита может быть основанием для повторной дифференциальной диагностики и реклассификации в пользу ювенильного ревматоидного артрита, не смотря на незначительную степень воспалительной активности заболевания и серонегативность по антинуклеарным антителам и HLAB27.

Ключевые слова: реактивный артрит, детский возраст, хламидия, микоплазма, уреаплазма

\section{Информация об авторах}

Панько Наталия Александровна, к. мед. н., доц. кафедры педиатрии № 2 Харьковского национального университета имени В. Н. Каразина, Проспект Юбилейный, 52a, Харьков, Украина, 61153

e-mail:panko@karazin.ua

https://orcid.org/0000-0002-3200-8942

Лебеи Ирина Степановна, д. мед. н., проф, кафедры педиатрии Харьковского национального университета имени В. Н. Каразина, ведущий научный сотрудник кардиоревматологического отделения ГУ «Институт охраны здоровья детей та подростков НАМН», Проспект Юбилейный, 52a, Харьков, Украина, 61153

e-mail: cardiorevm.iozdp@gmail.com https://orcid.org/0000-0003-0050-2898

Шевченко Наталия Станиславовна, д. мед. Н., заведующая кафедрой педиатрии № 2 Харьковского национального университета имени В. Н. Каразина, главный научный сотрудник кардиоревматологического отделения ГУ «Институт охраны здоровья детей та подростков НАМН», Проспект Юбилейный, 52a, Харьков, Украина, 61153

e-mail: natalia.shevchenko@karazin.ua https://orcid.org/0000-0003-4407-6050

Цюра Оксана Николаевна, к. мед. н., асистент кафедры педиатрии № 2 Харьковского национального университета имени В. Н. Каразина, Проспект Юбилейный, 52a, Харьков, Украина, 61153 e-mail: cyra@karazin.ua https://orcid.org/0000-0001-8245-015X Шлеенкова Анна Александровна, к. мед. н., доц. кафедры педиатрии № 2 Харьковского национального университета имени В. Н. Каразина, Проспект Юбилейный, 52a, Харьков, Украина, 61153

e-mail: shleenkova@karazin.ua https://orcid.org/0000-0001-9775-4324 Бутенко Антонина Игоревна, к. мед. н., доц. кафедры педиатрии № 2 Харьковского национального университета имени В. Н. Каразина, Проспект Юбилейный, 52a, Харьков, Украина, 61153

e-mail: antoninabutenko@karazin.ua https://orcid.org/0000-0002-0716-496X

Conflicts of interest: author has no conflict of interest to declare.

Конфлікт інтересів: відсутній.

Конфликт интересов: отсутствует. 


\title{
ХІМІЧНА ХАРАКТЕРИСТИКА БІОМЕМБРАН ГРАНУЛОЦИТІВ ПЕРИФЕРИЧНОЇ КРОВІ У ЧАСТО ХВОРИХ ДІТЕЙ ІЗ СИНДРОМОМ ВЕГЕТАТИВНИХ ДИСФУНКЦІЙ
}

\author{
Попов М. М., Оленич В. Б., Лядова Т. І., Соловйова А. Г., Огнівенко О. В.
}

Пошта для листування: t.lyadova@karazin.ua

\begin{abstract}
Резюме. Проблема часто хворих дітей (ЧХД) має велику актуальність у медичній практиці. Особливу групу складають ЧХД з синдромом вегетативних дисфункцій, народжених недоношеними з перинатальним ураженням центральної нервової системи (ЦНС). В проведених раніше дослідженнях було встановлено, що ЧХД, народжені недоношеними з перинатальним ураженням ЦНС, проявляють більш низьку іменореактивність, ніж їх здорові однолітки. Мета роботи - вивчення стану біохімічного показника імунокомпетентних клітин (вивчення фосфоліпідного складу мембран гранулоцитів) у ЧХД з синдромом вегетативних дисфункиій, народжених недонотеними з перинатальним ураженням ЦНС. Матеріали та методи. Було обстежено 68 дітей у вічі 6-7 років, які відносились до групи ЧХД. 3 них 36 дітей с синдромом вегетативних дисфункиій, які народжені недономеними з перинатальним ураженням ЦНС (1 група) та 32 дитини без синдрома вегетативних дисфункиій, які народжені вчасно без перинатального ураження ЦНС (2 група). Програма біохімічних досліджень включала вивчення фосфоліпідного складу мембран гранулочитів. Результати. Вивчення фосфоліпідного складу мембран гранулочитів крові пацієнтів, які вивчалися, виявило достовірні відміни з порівнянням з показниками групи контролю. Виявлені зміни у біомембранах гранулоиитів були більш виразними у ЧХД з синдромом вегетативних дисфункиій, які народжені недономеними 3 перинатальним ураженням ЦНС, ніж у ЧХД, які народжені вчасно без перинатального ураження ЦНС, та синдрома вегетативних дисфункцій. Висновки. Отриманні данні дозволяють зробити висновки, що у ЧХД, які народжені недоношеними з перинатальним ураженням ЦНС, спостерігаються зміни в біохімічних характеристиках мембран, ніж у дітей, які народжені в строк без ураження ЦНС. Виявлені зміни в імунокомпетентних клітинах, характеризуються підвищенням полярності ліпідного компонента біомембран та зменшенням відносного змісту в них нейтральних ліпідів. Данні порушення призводять до зміни білокліпідних взаємодій, щзо призводить к зміненню мікров'язкості біомембран та їх структурно-функиіональних властивостей. За результатами, які надано, можливо припустити, що у ЧХД, які народжені недоношеними, відмічається формування недосконалої імунної відповіді на інфекиійний агент. У свою чергу, зниження імунної реактивності сприяє персистениіії інфекиії та хронизаиії запального процесу.
\end{abstract}

Ключові слова: діти, які часто хворіють, синдром вегетативних дисфункцій, гранулоцити, імунореактивність

\begin{abstract}
Інформація про авторів
Попов Микола Миколайович, д. мед. н., проф. кафедри загальної та клінічної імунології та алергології Харківського національного університету імені В. Н. Каразіна, майдан Свободи, 6, Харків, Україна, 61022

e-mail: mykola.m.popov@karazin.ua https://orcid.org/0000-0002-5759-9654

Оленич Вера Борисівна, к. мед. н., доц. кафедри загальної та клінічної імунології та алергології Харківського національного університету імені В. Н. Каразіна; дитячий лікар-невролог КНП Харківської обласної ради «Обласна дитяча клінічна лікарня
\end{abstract}

№1», вул. Клочківська, 337А, Харків, Україна, 61000

e-mail: olenichvera@gmail.com https://orcid.org/0000-0002-4776-1486

Лядова Татьяна Іванівна, д. мед. н., зав. кафедри загальної та клінічної імунології та алергології Харківського національного університету імені В. Н. Каразіна, майдан Свободи, 6, Харків, Україна, 61022

e-mail: t.lyadova@karazin.ua

https://orcid.org/0000-0002-9255-6019

Огнівенко Олена Володимирівна,

к. мед. н., доц. кафедри загальної та клінічної імунології та алергології Харківського національного університету імені В. Н. Каразіна, майдан Свободи, 6, Харків, Україна, 61022

e-mail: ognivo38@gmail.com

https://orcid.org/0000-0003-3936-0305

Соловьева Ангелина Георгївна, к. мед. н., асистент кафедри загальної та клінічної імунології та алергології Харківського національного університету імені В. Н. Каразіна; заступник генерального директора КНП Харківської обласної ради «Обласна дитяча клінічна лікарня №1», вул. Клочківська, 337А, Харків, Україна, 61000

e-mail:7lina@ukr.net

\section{Вступ}

У медичній практиці проблема часто хворіючих дітей (ЧХД) має виняткову актуальність. Термін «часто хворіючі діти» з'явився у вітчизняній медичній літературі, в

першій половині 80-х років минулого століття, позначаючи групу дітей, що виділяється при диспансерному спостереженні, що характеризується більш високим, ніж у їхніх 
однолітків, рівнем захворюваності. У цих дітей часто виявляються хронічні захворювання ЛОРорганів, бронхо-легеневої системи, важче перебігаяє бронхіальна астма, ці діти схильні до вегетативних дисфункцій, захворювань шлунково-кишкового тракту. Вірусні та бактеріальні інфекції, як правило, виявляють резистентність до загальноприйнятих методів лікування, що включає противірусні та антибактеріальні препарати $[1,2,3]$.

Особливу групу складають ЧХД з синдромом вегетативної дисфункції, що народилися недоношеними 3 перинатальним ураженням центральної нервової системи (ЦНС). У цих дітей 3 6-7 років спостерігаються більш виражені порушення в неврологічному статусі, нейрофункціональній активності ЦНС в порівнянні з їх однолітками, народженими в строк без перинатального ураження ЦНС [4].

$\mathrm{y}$ раніше проведених дослідженнях нами встановлено, що ЧХД народжені недоношеними 3 перинатальним ураженням ЦНС, можуть виявляти більш низьку імунореактивність, ніж їхні здорові однолітки $[5,6,7,8]$.

Метою цієї роботи було вивчення стану біохімічних показників імунокомпетентних клітин (вивчення фосфоліпідного складу мембран гранулоцитів) у часто хворіючих дітей 3 синдромом вегетативної дисфункції, що народилися недоношеними 3 перинатальним ураженням центральної нервової системи (ЦНС).

\section{Матеріали та методи}

Нами обстежено 68 дітей у віці 6-7 років, що належать до групи ЧХД. 3 них 36 дітей 3 синдромом вегетативних дисфункцій (СВД), що народилися недоношеними 3 перинатальним гіпоксично-ішемічним ураженням ЦНС (1 група) i 32 дитини без синдрому вегетативних дисфункцій, які народилися в строк без ураження ЦНС (2 група).

Часті захворювання протікали у вигляді хронічних фарингітів (МКБ X - J31.0), хронічних тонзилітів (МКБ X - J03), рецидивних бактеріальних риносинуситів (МКБ Х - J01.8).

Діагноз СВД виставлявся відповідно МКБ Х G 90.9 (розлад вегетативної нервової системи, неуточнені). Відповідно до робочої класифікації: синдром вегетативної дисфункції, змішаний тип, перманентний перебіг (Н.А. Білоконь, 1987) і був верифікований з урахуванням патогномонічних клінічних проявів захворювання, даних лабораторних та інструментальних методів досліджень. Всі діти (1 і 2 групи) були піддані комплексному клінічному обстеженню, яке включало: збір скарг, анамнезу, об'єктивний огляд дитини, проведення стандартних клінічних та інструментальних досліджень. Обстеження дітей проводилося на базі Регіонального центру дитячої імунології ОДКБ №1 м. Харкова.

У дослідження не включали дітей 3 пароксизмальним i перманентнопароксизмальним перебігом СВД, які в анамнезі мали родову травму, аутоімунні та алергічні захворювання, ураження герпесвірусною інфекцією, захворювання крові, шлунковокишкового тракту, ендокринні розлади, серцевосудинну патологію. Контрольну групу склали 30 здорових дітей того ж віку.

Програма біохімічних досліджень включала: вивчення фосфоліпідного складу мембран гранулоцитів.

Фосфоліпідний склад мембран гранулоцитів вивчали хроматографічно. Екстракцію ліпідів 3 нейтрофілів проводили за методом Фолча. Отриманий осад плазматичних мембран клітин ресуспензували у скляних центрифужних пробірках, які вміщували не менше 20 обсягів хромотоформ-метанолової суміші (2:1 за обсягом) і витримували на холоді протягом 1 години. Після центрифугування супернатант зливали в скляні центрифужні пробірки. Для повноти екстракції до осаду доливали хромотоформ-метанолову суміш і після центрифугування натанти об'єднували. Для відділення водорозчинних домішок в екстракт додавали розчин 0,05 мл $\mathrm{CaCl}$ з розрахунку 1:5 за обсягом і ретельно перемішували. Для розділу на дві фази емульсію залишали на ніч на холоді. 3 нижньої хроматографічної фази отримували препарат сумарних ліпідів.

Тонкошарову хроматографію фосфоліпідів проводили на активованих сілікогелевих пластинках, шляхом нанесення фосфоліпідної фракції, підсушували і ставили в хроматографічну камеру. Фосфоліпіди поділяли на фракції за допомогою системи хлороформ метанол - оцтова кислота - вода (60:50:1:4). Після підйому рівня розчинника до краю пластинки хроматографію зупиняли і обробляли ії розчином йоду для вирівнювання плям. Кількісне визначення ліпідів проводили безпосередньо на 
хроматограмах, які оброблені парами йоду, за допомогою денситометра «Model GS-670», 3 певним програмним забезпеченням $[9,10,11]$.

Стан білкових і ліпідних компонентів мембран гранулоцитів спектрофлюорометрічно за допомогою флюоресцентних зондів. Використовували зонд AHC (анілінонафталінсульфокіслоту), яка флюорисцює тільки при абсорбції ії білками; МНКС (2-метил-5-нітроізокарбостріл), флюоресцюючий при розчиненні в малярних ліпідах; ГГБАК (7-гідроксі-6-гексил-3 (2бензімідазолін) - амінокумарін), який володіє ліпофільними властивостями i, завдяки бічному ланцюжку, може проникати в ліпідний шар мембрани, де переходить у флюоресцюючу таутомерну форму [12].

Статистичну обробку даних проводили за допомогою Microsoft XL 2007 і програми Med Stat (серійний №MS000055) ДІВП ТОВ «Альфа» відповідно до рекомендацій статистичної обробки медико-біологічних даних. Проводили перевірку вибірок на нормальність розподілів (критерій $\mathrm{x} 2$ ), обчислювали середню арифметичну (M), і середню помилку середньої величини (m), визначали достовірність відмінностей по $\mathrm{t}$-критерієм Стьюдента. Критичний рівень значущості вважали рівним $0,05[13,14]$.

\section{Результати та їх обговорення}

Вивчення фосфоліпідного складу мембран гранулоцитів крові у пацієнтів досліджуваних груп виявило достовірні відмінності в порівнянні 3 показниками групи контролю. Так, в першій групі дослідження відзначено зниження вмісту фосфатиділхоліну (ФХ) на 36 \% і в другій на $25 \%$; сфінгомієлінів (СФМ) - на 45 \% і 28 \% відповідно; фосфатиділсерін (ФС) - на $32 \%$ в першій групі і $15 \%$ у другій; відносне підвищення вмісту фосфатіділетаноламіну (ФЕА) на 44 \% у 1-ї групи і на $20 \%$ у 2-ї групи хворих. Концентрація лізофосфатиділхоліна (ЛФХ) також була відносно вище на $21 \%$ (1-а група) і на 30 \% (2-a група). Вміст фосфатиділхолінозитолів (ФХЛ) було достовірно вище на 31 \% і 17 \% у пацієнтів досліджуваних груп порівняно 3 контрольною групою осіб (табл. 1).

Слід зазначити, що серед дітей 1-ї групи ці зміни були більш вираженими в порівнянні 3 показниками дітей 2-ї групи і контрольними даними ( $\mathrm{p}<0,05)$.

Відомо, що сфінгомієліни в своєму складі в основному містять залишки насичених жирних кислот, фосфатиділетаноламін - навпаки, велику кількість ненасичених жирних кислот. Збільшення відносного змісту фосфатіділетаноламіну в мембранах гранулоцитів, ймовірно, можна розглядати як компенсаторну реакцію, яка спрямована на підтримку структурної цілісності та функціональної активності біомембран.

Спектрофлюорометричне вивчення мембран клітин за допомогою зондів показало, що гранулоцити хворих 1 і 2-ї групи, оброблені зондом АНС, який зв'язується 3 білковими компонентами мембран, виявляє відповідно на $60,1 \%$ і 43,5 \% менший рівень флюоресценції, порівняно з клітинами дітей контрольної групи.

Таблиия 1. Фосфоліпідний склад мембран гранулочитів периферичної крові дітей 1 і 2 групи,

\begin{tabular}{|c|c|c|c|}
\hline \multirow{3}{*}{ Фракції } & & & $(M \pm m)$ \\
\hline & \multicolumn{2}{|c|}{ Діти } & \multirow{2}{*}{$\begin{array}{c}\text { Контрольна група } \\
(\mathrm{n}=30)\end{array}$} \\
\hline & 1 група, $(\mathrm{n}=36)$ & 2 група, $(\mathrm{n}=32)$ & \\
\hline $\begin{array}{l}\text { Фосфатиділетаноламіни (ФЕА), } \\
\text { у.о. }\end{array}$ & $0,379 \pm 0,003^{1,2}$ & $0,316 \pm 0,003^{1}$ & $0,263 \pm 0,002$ \\
\hline Фосфатиділхоліни (ФХ), у.о. & $0,193 \pm 0,005^{1,2}$ & $0,224 \pm 0,006^{1}$ & $0,298 \pm 0,003$ \\
\hline Фосфатиділсеріни (ФС), у.о. & $0,096 \pm 0,006^{1,2}$ & $0,119 \pm 0,006^{1}$ & $0,140 \pm 0,003$ \\
\hline Фосфатиділінозитоли (ФІ) у.о. & $0,156 \pm 0,007^{1,2}$ & $0,140 \pm 0,007^{1}$ & $0,119 \pm 0,003$ \\
\hline Сфінгомієліни (СФМ), у.о. & $0,056 \pm 0,006^{1,2}$ & $0,073 \pm 0,006^{1}$ & $0,101 \pm 0,004$ \\
\hline $\begin{array}{l}\text { Лізофосфатиділхоліни (ЛФХ), } \\
\text { у.о. }\end{array}$ & $0,115 \pm 0,005^{1,2}$ & $0,107 \pm 0,007^{1}$ & $0,088 \pm 0,004$ \\
\hline
\end{tabular}


Додавання зонда МНКС, який розчиняється в полярних ліпідах, навпаки, дає посилення флюоресценції клітин на 161 \% і 145 \%, що вказує на збільшення полярності ліпідів мембран гранулоцитів. При обробці клітин зондом ГГБАК, що володіє ліпофільними властивостями, інтенсивність флюоресценції клітин знижується відповідно на 48 \% і $41 \%$ порівняно з контролем.

\section{Обговорення результатів}

тримані дані свідчать про те, що у ЧБД спостерігається збільшення вмісту ненасичених жирних кислот i порушення співвідношення ненасичені/насичені жирні кислоти. Виявлені зміни в біомембранах гранулоцитів були більш виражені у дітей 3 СВД, які народилися недоношеними 3 перинатальним ураженням ЦНС, ніж у дітей, що народилися в строк без ураження ЦНС і СВД.

Збільшення вмісту ненасичених жирних кислот в фосфоліпідах свідчить про зниження в'язкості біомембран клітин [15]. У свою чергу, такий стан біошару клітин сприяе порушенню занурення рецепторів у мембрану і зниження ефективності їх взаємодії з лігандом.

\section{Висновки}

Отримані дані дозволяють зробити висновок, що у ЧХД, як народилися недоношеними 3 перинатальним ураженням ЦНС, так i народжених у строк без ураження ЦНС, виявлені зміни в імунокомпетентних клітинах характеризуються підвищенням полярності ліпідного компонента біомембран і зменшенням відносного вмісту в них нейтральних ліпідів. Дані порушення призводять до зміни білок-ліпідних взаємодій, що, в підсумку, призводить до зміни мікров'язкості біомембран i $і$ ї структурнофункціональних властивостей.

У ЧХД, які народилися недоношеними 3 перинатальним гіпоксично-ішемічним ураженням ЦНС в дещо більшою мірою спостерігаються зміни біохімічних показників мембран, в порівнянні 3 групою ЧХД, що народилися в строк без ураження ЦНС.

Слід зазначити, що стан біомембран імунокомпетентних клітин знаходиться в тісній залежності з активністю рецепторного апарату. Рецептори клітин в імунних реакціях відіграють виняткову роль, від їх структурно-біологічних властивостей залежить якість рецепції, трансдукції активаційних і регуляторних сигналів, і в підсумку, ефективність розвитку і реалізації імунної відповіді. Вищевикладені результати дозволяють припустити, що у ЧХД, які народилися недоношеними, з перинатальним гіпоксично-ішемічним ураженням ЦНС відзначається формування неповноцінної імунної реакції на інфекційний агент.

У свою чергу, зниження імунореактивності організму сприяє персистенції інфекції та хронізації запального процесу.

\section{Перспективи подальших досліджень}

Надалі $€$ перспективним підбір і вивчення ефективності імунотерапії на стан антимікробного імунітету у часто хворіючих дітей, які народилися недоношеними 3 перинатальним ураженням ЦНС.

Результати, отримані в ході роботи, повинні бути підтверджені в дослідженні 3 великим числом спостережень.

Дослідження виконано в рамках НДР «Роль імунних, аутоімунних та метаболічних розладів у патогенезі інфекційного процесу, що викликаний бактеріями, вірусами, вірусно-бактеріальними асоціаціями при гострому, затяжному та хронічному перебігу хвороби та оптимізація засобів лікування» № 0117U004874

\section{Список літератури}

1. Лукащук CB, Лемко ОI. Часті та рецидивуючі респіраторні інфекції у дітей: сучасний стан проблеми (огляд літератури). Проблеми клінічної педіатрії. 2016;3-4:66-71. doi: 10.31655/2307-3373-2018-4-7-11

2. Лукащук СВ, Лемко ОI. Принципи ведення дітей із частими та рецидивними захворюваннями дихальних шляхів (огляд літератури). Сучасна педіатрія. 2016;7:48-52. doi: 10.15574/SP.2016.79.48

3. Мойсеєнко РО, Дудіна ОО, Гойда НГ. Аналіз стану захворюваності та поширеності захворювань у дітей в Україні за період 2011-2015 роки. Современная педиатрия.

2017;2(82):17-27.

doi:

10.15574/SP.2017.82.17

4. Reggie HC Lee, Michelle HH Lee, Celeste YC Wu. Cerebral ischemia and neuroregeneration. Neural Regen Res. 2018;13(3):373-385. doi: 10.4103/1673-5374.228711.

5. Попов НН, Оленич ВБ, Савво АН. Цитокиновый статус и баланс клеток иммунной системы у детей с синдромом вегетативной дисфункции, родившихся недоношенными с перинатальным поражением центральной нервной системы (ЦНС). Современный научный вестник. 2014;31(227):49 - 56.

6. Попов НН, Оленич ВБ, Огнивенко ЕВ, Савво $\mathrm{AH}$. Клинические проявления синдрома вегетативной дисфункции у детей с хроническим гнойным синуситом B: Modern scientific potential - 2017: materials of the XIII 
International scientific and practical Conference; 2017 лют 8- бер 7; Sheffield. Sheffield, England; 2017. C. 3-6.

7. Попов НН, Пиантковская ОВ, Оленич ВБ, Савво $\mathrm{OH}$, Соловьева АГ. Уровень цитокинов и фактора адгезии сыворотки крови при бронхиальной астме у детей. В: Международная академия Jornal Web of Scholar, № 9(18), Vol.1, 30 листопада, 2017 року.: тези доп. Dubai, UAE, 2017. Р. $72-76$.

8. Попов ММ, Піантковська ОВ, Оленич ВБ, Савво ОН, Огнівенко ЕВ. Нейроадаптогени у лікуванні дітей, які перенесли перинатальні гіпоксично-ішемічні ураження центральної нервової системи. B: International Trends in Science and Technology : Proceedings of the XIV International Scientific and Practical Conference; 2019 June 30; Warsaw. Warsaw, Poland; 2019. P. 34-37.

9. Сенчук ВВ. Курс лекций по биохимии. Минск: БГУ, 2005. Ч.1. Биомолекулы. С.137-139.

10. Северин СЕ, Соловьева ТА. Практикум по биохимии : практ. пособ. Москва: МГУ, 1989. - 509 с.

11. Канская НВ, Иванов ВВ, Степовая ЕА. Модификация способа определения липидов. Сибирский медицинский журнал. 2014;29(1):69-73. https://doi.org/10.29001/2073-8552-2014-29-1-69-73

12. Владимиров ЮА, Добрецов Т Е. Флюоресцентные зонды в исследовании биологических мембран : практ. пособ. Москва: Наука, 1980. 320 с.

13. Boulgouris NV, Plataniotis KN. Biometrics: Theory, Methods, and Applications. Hoboken, NJ: Wiley, 2009. 763 p.

14. Meloun M, Militky J. Statistical Data Analysis: A Practical Guide. Woodhead Publishing, 2011. 800 p.

15. Попов НН, Огнивенко ЕВ. Физико-химические и биологические свойства мембран нейтрофильных гранулоцитов больных хроническим гнойным верхнечелюстным синуситом, страдающих сахарным диабетом. Экспериментальная и клиническая медицина. 2007;3:8 - 12 .

\section{References}

1. Lukashchuk SV, Lemko OI. Parts of and recurrent respiratory infections in children: current problems (review). Problems of Clinical Pediatrics. 2016; 3-4: 66-71. doi: 10.31655/2307-3373-2018-4-7-11

2. Lukashchuk SV, Lemko OI. Principles of management of children with frequent and recurrent illness of airways (review). Modern pediatrics. 2016; 7: 48-52. doi: 10.15574/SP.2016.79.48

3. Moiseenko RO, Dudina OO, Goyda NG. Analysis of the incidence and prevalence of diseases in children in Ukraine for the period 2011-2015. Modern pediatrics. 2017; 2 (82): 17-27. doi: 10.15574/SP.2017.82.17
4. Reggie HC Lee, Michelle HH Lee, Celeste YC Wu. Cerebral ischemia and neuroregeneration. Neural Regen Res. 2018;13(3):373-385. doi: 10.4103/1673-5374.228711.

5. Popov NN, Olenich VB, Savvo AN. Cytokine status and balance of cells of the immune system in children with autonomic dysfunction syndrome born prematurely with perinatal lesions of the central nervous system (CNS). Modern scientific bulletin. 2014; 31 (227): 49 - 56.

6. Popov NN, Olenich VB, Ognivenko YeV, Savvo AN. Clinical manifestations of vegetative dysfunction syndrome in children with chronic purulent sinusitis B: Modern scientific potential - 2017: materials of the XIII International scientific and practical Conference; 2017 Feb 8 - Mar 7; Sheffield. Sheffield, England; 2017. P. 3-6.

7. Popov NN, Piantkovskaya OV, Olenych VB, Savvo ON, Solovyova AG. The level of cytokines and blood serum adhesion factor in bronchial asthma in children. In: International Academy Jornal Web of Scholar, No. 9 (18), Vol.1, 30 leaf fall, 2017 rock.: abstracts. Dubai, UAE, 2017. P. 72-76.

8. Popov NN, Piantkovskaya OV, Olenych VB, Savvo ON, Ognivenko YeV. Neuroadaptogenics in children who have undergone perinatal hypoxic-ischemic lesions of the central nervous system. In: International Trends in Science and Technology: Proceedings of the XIV International Scientific and Practical Conference; 2019 June 30; Warsaw. Warsaw, Poland; 2019. P. 34-37.

9. Senchuk VV. A course of lectures on biochemistry. Minsk: BSU, 2005. Part 1. Biomolecules. P. 137-139.

10. Severin SYe, Soloveva TA. Biochemistry workshop: practical. manual. Moscow: Moscow State University, 1989. 509 pp.

11. Kanskaya NV, Ivanov VV, Stepovaya YeA. Modification of the method for determining lipids. Siberian Medical Journal. 2014; 29 (1): 69-73. https://doi.org/10.29001/2073-8552-2014-29-1-69-73

12. Vladimirov YuA, Dobretsov TYe. Fluorescent probes in biological membranes research: Pract. manual. Moscow: Science, 1980. 320 pp.

13. Boulgouris NV, Plataniotis KN. Biometrics: Theory, Methods, and Applications. Hoboken, NJ: Wiley, 2009. $763 \mathrm{p}$.

14. Meloun M, Militky J. Statistical Data Analysis: A Practical Guide. Woodhead Publishing, 2011. 800 p.

15. Popov NN, Ognivenko YeV. Physicochemical and biological properties of membranes of neutrophilic granulocytes of patients with chronic purulent maxillary sinusitis suffering from diabetes mellitus. Experimental and Clinical Medicine. 2007; 3: 8-12.

\title{
CHEMICAL CHARACTERISTICS OF PERIPHERAL BLOOD GRANULOCYTE BIOMEMBRANES IN FREQUENTLY ILL CHILDREN WITH AUTONOMIC DYSFUNCTION SYNDROME
}

\author{
Popov Mykola, Olenych Vera, Liadova Tetiana, Ognivenko Olena, Soloviova Angelina
}

Mail for correspondence: Panko@karazin.ua t.lyadova@karazin.ua

The problem of frequently ill children has extreme relevance in medical practice. A special group is FIC with autonomic dysfunction syndrome, born prematurely with perinatal damage of the central nervous 
system (CNS). In previous studies, we found that FIC who were born prematurely with perinatal damage of the central nervous system exhibit lower immunoreactivity than their healthy peers. Purpose of the work - to study the biochemical indicator of immunocompetent cells (the study of the phospholipid composition of granulocyte membranes) of the frequently ill children with autonomic dysfunction syndrome, born prematurely with perinatal damage to the central nervous system (CNS). Materials and methods. 68 children in the age of 6-7 years who are belonging to the group of frequently ill were examined. Out of 68 children, there were 36 children with autonomic dysfunction syndrome (SVD) born prematurely with perinatal hypoxic-ischemic damage to the central nervous system (group 1) and 32 children without autonomic dysfunction syndrome born on time without central nervous system damage (group 2). Results. A study of the phospholipid composition of blood granulocyte membranes of patients of the studied groups revealed significant differences comparison with the control group. The revealed changes in granulocyte biomembranes were more pronounced for FIC with SVD born prematurely with perinatal CNS damage than for children born on time without CNS and SVD damage. Conclusions. The obtained data allow us to conclude that FIL who were born preterm with perinatal damage of the central nervous system, changes in the biochemical characteristics of membranes are observed to a slightly greater extent than for children who were born on time without central nervous system damage. The revealed changes in immunocompetent cells are characterized by an increase in the polarity of the lipid component of biomembranes and a decrease in the relative content of neutral lipids in them. These violations lead to a change in protein-lipid interactions, which, as a result, leads to a change in the microviscosity of biomembranes and their structural and functional properties. At these children forme an inferior immune response to an infectious agent.

Key words: frequently ill children, autonomic dysfunction syndrome, granulocytes, immunoreactivity, CNS, SVD

\section{Information about author}

Popov Mykola, MD, PhD, DSc, Full Professor of the Department of General and Clinical Immunology and Allergology, V.N. Karazin Kharkiv National University, 6, Svobody sq., Kharkiv, Ukraine, 06122 e-mail: mykola.m.popov@karazin.ua https://orcid.org/0000-0002-5759-9654 Olenych Vera, MD, PhD, Associate Professor of the Department of General and Clinical Immunology and Allergology, V.N. Karazin Kharkiv National University, neurologi of the "Regional Children's
Clinical Hospital №1”, st. Klochkovskaya, 337A, Kharkiv, Ukraine, 61000 e-mail: olenichvera@gmail.com https://orcid.org/0000-0002-4776-1486 Liadova Tetiana., $\mathrm{MD}, \mathrm{PhD}, \mathrm{DSc}$, Professor, Head of the Department of General and Clinical Immunology and Allergology, V.N. Karazin Kharkiv National University, 6, Svobody sq.,

Kharkiv, Ukraine, 06122

e-mail: t.lyadova@karazin.ua https://orcid.org/0000-0002-9255-6019 Ognivenko Olena, $\mathrm{MD}, \mathrm{PhD}$, Associate

Professor of the Department of General and
Clinical Immunology and Allergology, V.N. Karazin Kharkiv National University, 6, Svobody sq., Kharkiv, Ukraine, 06122 e-mail: ognivo38@gmail.com https://orcid.org/0000-0003-3936-0305 Soloviova Angelina, MD, $\mathrm{PhD}$, assistant of the Department of General and Clinical Immunology and Allergology, V.N. Karazin Kharkiv National University, Ukraine deputy of the general director of the "Regional Children's Clinical Hospital №1”, Klochkovskaya, 337A, Kharkiv, Ukraine, 61000 e-mail: 7lina@ukr.net

\title{
ХИМИЧЕСКАЯ ХАРАКТЕРИСТИКА БИОМЕМБРАН ГРАНУЛОЦИТОВ ПЕРИФЕРИЧЕСКОЙ КРОВИ У ЧАСТО БОЛЕЮЩИХ ДЕТЕЙ С СИНДРОМОМ ВЕГЕТАТИВНЫХ ДИСФУНКЦИЙ
}

\author{
Попов Н. Н., Оленич В. Б., Лядова Т. И., Соловьева А. Г., Огнивенко Е. В.
}

Почта для переписки: t.lyadova@karazin.ua

\begin{abstract}
Резюме. Проблема часто болеющих детей имеет исключительную актуальность в медицинской практике. Особую группу составляют ЧБД с синдромом вегетативной дисфункиии, родившиеся недоношенньми с перинатальным поражением иентральной нервной системы (ЦНС). В ранее проведенных исследованиях нами установлено, что ЧБД рожденные недоношенными с перинатальным поражением ЦНС, проявляют более низкую иммунореактивность, чем их здоровые сверстники. Цель работы-изучение состояния биохимического показателя иммунокомпетентных клеток (изучение фосфолипидного состава мембран гранулочитов) у часто болеющих детей с синдромом вегетативной дисфункции, родивиихся недоношенными с перинатальным поражением центральной нервной системы (ЦНС). Материалы и методы. Было обследовано 68 детей в возрасте 6-7 лет относящихся к группе часто болеющих. Из них 36 детей с синдромом вегетативных дисфункиий (СВД), родивщихся недономенными с перинатальным гипоксически-ишемическим поражением ЦНС (1 группа) и 32 ребенка без синдрома вегетативных дисфункиий, родившихся в срок без поражения ЦНС (2 группа). Программа биохимических
\end{abstract}


исследований включала: изучение фосфолипидного состава мембран гранулоцитов. Результаты. Изучение фосфолипидного состава мембран гранулоцитов крови у пациентов исследуемьх групп выявило достоверные отличия по сравнению с показателями группы контроля. Выявленные изменения в биомембранах гранулочитов были более выражены у ЧБД с СВД, родившихся недоношенными с перинатальным поражением ЦНС, чем у детей, родившихся в срок без поражения ЦНС и СВД. Выводы. Полученные данные позволяют прийти к выводу, что у ЧБД, родившихся недоношенными с перинатальным поражением ЦНС, в несколько большей степени наблюдаются изменения в биохимических характеристиках мембран, чем у детей родившихся в срок без поражения ЦНС. Выявленные изменения в иммунокомпетентных клетках характеризуются повышением полярности липидного компонента биомембран и уменьшением относительного содержания в них нейтральных липидов. Данные нарушения приводят к изменению белок-липидньх взаимодействий, что, в итоге, приводит к изменению микровязкости биомембран и их структурно-функцииональных свойств.

Ключевые слова: часто болеющие дети, синдром вегетативных дисфункций, гранулоциты, иммунореактивность

\section{Информация об авторах}

Попов Николай Николаевич, д. мед. н., проф. кафедры общей и клинической иммунологии и аллергологии Харьковского национального университета имени В. Н. Каразина, пл. Свободы, 6, Харьков, Украина, 61022 e-mail: mykola.m.popov@karazin.ua https://orcid.org/0000-0002-5759-9654 Оленич Вера Борисовна., к. мед. н., доц. кафедры общей и клинической иммунологии и аллергологии Харьковского национального университета имени В. Н. Каразина, Украина; детский врач-невролог КНП Харьковского областного совета «Областная детская клиническая больница №1», ул. Клочковськая, 337А,
Харьков, Украина, 61000 e-mail: olenichvera@gmail.com https://orcid.org/0000-0002-4776-1486 Лядова Татьяна Ивановна, д. мед. н., заведующая кафедрой общей и клинической иммунологии и аллергологии Харьковского национального университета имени В. Н. Каразина, пл. Свободи, 6, Харьков, Украина, 61022

e-mail: t.lyadova@karazin.ua https://orcid.org/0000-0002-9255-6019

Огнивенко Елена Владимировна, к. мед. н., доц. кафедры общей и клинической иммунологии и аллергологии Харьковского национального университета имени
В. Н. Каразина, пл. Свободи, 6, Харьков, Украина, 61022

e-mail: ognivo38@gmail.com https://orcid.org/0000-0003-3936-0305

Соловьева Ангелина Георгиевна, к. мед. н., ассистент кафедры общей и клинической иммунологии и аллергологии Харьковского национального университета имени В. Н. Каразина; заместитель генерального директора КНП Харьковского областного совета «Областная детская клиническая больница №1», ул. Клочковськая, 337А, Харьков, Украина, 61000 e-mail: 7lina@ukr.net

Conflicts of interest: author has no conflict of interest to declare.

Конфлікт інтересів: відсутній.

Конфликт интересов: отсутствует. 


\title{
СТОСОВНО ПИТАННЯ ПРО ВСТАНОВЛЕННЯ СТУПЕНЯ ТЯЖКОСТІ ТІЛЕСНИХ УШКОДЖЕНЬ ПРИ ВІДКРИТИХ ПЕРЕЛОМАХ НИЖНІХ КІНЦІВОК
}

\author{
Сокол В. К., Ольховський В. О., Колесніченко В. А.
}

Пошта для листування: 28111957vk@gmail.com

\begin{abstract}
Резюме: Існуючі в даний час «Правила визначення ступеня тяжкості тілесних ушкоджень» не відповідають сучасній класифікаиії, рівню знань про клінічний перебіг і результати відкритих переломів нижніх кінцівок. Мета - провести порівняльний ретроспективний аналіз результатів судово-медичних експертиз по визначенню ступеня тяжкості тілесних ушкоджень у потерпілих з відкритими $i$ закритими переломами нижніх кінцівок. Матеріали та методи. Матеріал дослідження - 425 актів (170 первинних, 185 комісійних, 70 комплексних) судово-медичних експертиз постраждалих з переломами стегнової та / або великогомілкової кісток, щзо проведені в Харківському обласному бюро судово-медичної експертизи за період лютий - червень 2018 року. Методи дослідження - ретроспективний аналіз, описова статистика. Результати. Встановлено, щзо як на момент травми, так і у разі ї̈ (травми) наслідків у постраждалих з переважаючою травмою нижніх кінцівок відкриті переломи стегнової $i$ великогомілкової кісток оцінюються як тяжкі тілесні ушкодження без урахування характеру перелому $i$ ступеня пошкодження м'яких тканин (за загальноприйнятими класифікаціями), хоча ці дані визначають особливості лікувальних заходів і прогнозу травми на догоспітальному та госпітальному етапах. Висновки. Відкриті переломи довгих кісток нижніх кінцівок I і II типу за клінічним перебігом, лікувальними підходами, ризиком розвитку ускладнень суттєво відрізняються від відкритих переломів III типу. Необхідна розробка критеріїв диферениійованої судово-медичної експертної оиінки відкритих переломів нижніх кінцівок на основі сучасних знань щэодо механогенезу відкритої травми, їі клінічного перебігу і наслідків.
\end{abstract}

Ключові слова: відкритий перелом нижніх кінцівок, судово-медична експертиза, ступінь тяжкості тілесних ушкоджень, наслідки травми

\author{
Інформація про авторів \\ Сокол Вячеслав Костянтинович, \\ к. мед. н., доц. кафедри судової \\ медицини, медичного правознавства ім. \\ засл. проф. М. С. Бокаріуса Харківського \\ національного медичного університету, \\ вул. Дмитрівська 14/16, Харків, 61052 \\ e-mail: sokol_vk@ukr.net \\ https://orcid.org/0000-0002-8892-1765
}

Ольховський Василь Олексійович, д. мед. н., проф. кафедри судової медицини, медичного правознавства ім. засл. проф. М. С. Бокаріуса Харківського національного медичного університету, вул. Дмитрівська 14/16, Харків, 61052 e-mail: prof_olhovsky@ukr.net https://orcid.org/0000-0003-2843-2692
Колесніченко Віра Анатолївна, д. мед. н., проф. кафедри хірургічних хвороб, оперативної хірургії та топографічної анатомії Харківського національного університету імені В. Н. Каразіна, майдан Свободи 6, Харків, 61022

e-mail: 28111957vk@gmail.com https://orcid.org/0000-0003-0503-9732
Дана робота $є$ фрагментом НДР кафедри судової медицини, медичного правознавства імені засл. проф. М.С. Бокаріуса Харківського національного медичного університету «Судово-медичне обгрунтування морфоклінічніх крітеріїв для експертної оцінки тілесніх ушкодженнь, визначення терміну давності та причини смерти», № держреєстрації 0115U000229.

Вступ. Відкриті переломи нижніх кінцівок відносяться до високоенергетичних механічних травм і зазвичай супроводжуються пошкодженням інших сегментів опорнорухової системи (множинна травма) та / або інших органів і систем організму (поєднана травма). Хворі 3 відкритими переломами потребують невідкладної травматологічної допомоги навіть у разі ізольованого ушкодження довгої трубчастої кістки $[1,2]$, так як лікування відкритої кісткової рани пов'язано 3 більш високим ризиком розвитку ранніх (нагноєння м'яких тканин) і пізніх (хронічний остеомієліт) інфекційних ускладнень [3, 4], збільшенням частоти незрощення $[5,6]$ в порівнянні з закритими переломами такої ж локалізації.

Прогноз щодо життя хворого, а також збереження повноцінно функціонуючої кінцівки залежить від ступеня пошкодження м'яких тканин. Згідно найбільш загальноприйнятої у світі класифікації Gustilo Anderson, 1976, прогностично несприятливими

(C) Сокол В. К., Ольховський В. О., Колесніченко В. А., АРРМ, 2020 
є відкриті переломи III типу з розмірами рани понад $10 \mathrm{~cm}$ і розчавленням м'яких тканин (IIIA); дефектом шкіри та інших м'яких тканин (IIIB) 3 пошкодженням магістральних судин і нервів (IIIC ) [7]. У хворих 3 відкритими переломами нижніх кінцівок III типу збільшується ризик смерті на місці події в результаті гострої крововтрати $[8,9]$, а також відзначається більш високий відсоток летальних випадків внаслідок розвитку системних ускладнень (геморагічного шоку, поліорганної недостатності, сепсису) $[10,11]$. Дефекти м'яких тканин і оголення кісткових фрагментів на всьому протязі рани, властиві відкритим переломам III типу, є суттєвими перешкодами для збереження життєздатної кінцівки [12].

Клінічний перебіг післятравматичного періоду і наслідки відкритих переломів нижніх кінцівок II (розмір рани від 1 до $10 \mathrm{~cm} 3$ незначним ушкодженням м'язів [7]) і особливо I типу (з розмірами рани, що не перевищують 1 см [7]), а також закритих переломів такої ж локалізації порівняні $[6,13,14]$.

Існуючі в даний час «Правила судовомедичного визначення ступенів тяжкості тілесніх ушкоджень», затверджені наказом MO3 України від 17 січня 1995 року № 6 [15], розглядають відкриті переломи діафіза плечової, стегнової і великогомілкової кісток aпріорі як тяжкі тілесні ушкодження, небезпечні для життя, незалежно від типу перелому (простий без уламків; відламковий; вибуховий), характеру пошкодження м'яких тканин та наслідків травми. В даний час пропонується внести певні зміни в «Правила ...», проте в частині експертної оцінки перераховані вище відкриті переломи, як i чверть століття тому, розцінюються як тяжкі тілесні ушкодження. У той же час дані сучасної літератури свідчать про різну ступень тяжкості i, відповідно, значні відмінності в плані небезпеки для життя потерпілого, життєздатності його травмованої нижньої кінцівки та наслідків відкритих переломів I, II, III типу. У зв'язку з тим, що відкриті переломи I i II типів за клінічною оцінкою та принципами лікування є ближчими до закритих переломів такої ж локалізації, уявляється доцільним порівняння експертної оцінки тяжкості травми при відкритих і закритих переломах нижніх кінцівок.

Мета - провести порівняльний ретроспективний аналіз результатів судовомедичних експертиз по визначенню ступеня тяжкості тілесних ушкоджень у потерпілих 3 відкритими і закритими переломами нижніх кінцівок.

Матеріали та методи. Матеріал дослідження - 425 актів судово-медичних експертиз (СМЕ) постраждалих з відкритими і закритими переломами стегнової та / або великогомілкової кісток, що проведені в Харківському обласному бюро судовомедичної експертизи за період лютий - червень 2018 року. Матеріал дослідження (425 CME) склали: 170 (40,0 \%) актів первинних судовомедичних експертиз, 185 (43,5\%) - комісійних та $70(16,5 \%)$ - комплексних CME.

Критерії включення - нелетальна механічна травма нижніх кінцівок (ізольована чи політравма), що призвела до відкритих і / або закритих переломів стегнової та / або великогомілкової кісток.

Критерії виключення - летальна політравма; переломи довгих кісток нижніх кінцівок, отримані в результаті впливу не механічної травми.

Відбір актів СМЕ проводився випадковою вибіркою.

Найбільш поширеним механізмом утворення переломів стегнової та / або великогомілкової кісток з'явилися дорожньотранспортні пригоди (ДТП) - 405 (95,3%) актів CME. Найчастіше в ДТП потрапляли пішоходи (369; 86,8 \%); другою за частотою виявилася внутрісалонна травма, в якій на частку водіїв $\mathrm{i}$ пасажирів легкових автомобілів припало 3,8 \% і 2,3\% відповідно. Серед інших механізмів утворення переломів нижніх кінцівок були падіння з невеликої висоти (до 3м) і побутові травми - 3,6 \% і 1,1% відповідно (табл.1). 
Таблиця 1. Розподіл постраждалих з переломами стегнової $i$ великогомілкової кісток $в$ залежності від механізму і характеру механічної травми

\begin{tabular}{|l|c|c|c|c|}
\hline \multirow{2}{*}{\multicolumn{1}{|}{ Механізм травми }} & \multicolumn{3}{|c|}{ Характер травми } & \multirow{2}{*}{ Всього } \\
\cline { 1 - 4 } & Ізольована & Множинна & Поєднана & \\
\hline Дорожньо-транспортні пригоди & \multicolumn{3}{|c|}{} \\
\hline - пішохід & $14 ; 3,3 \%$ & $24 ; 5,6 \%$ & $331 ; 77,9 \%$ & $369 ; 86,8 \%$ \\
\hline - водій легкового автомобіля & - & $2 ; 0,5 \%$ & $14 ; 3,3 \%$ & $16 ; 3,8 \%$ \\
\hline $\begin{array}{l}\text { - пасажир легкового } \\
\text { автомобіля }\end{array}$ & - & $1 ; 0,2 \%$ & $9 ; 2,1 \%$ & $10 ; 2,3 \%$ \\
\hline - водій мотоциклу & - & - & $4 ; 0,9 \%$ & $4 ; 0,9 \%$ \\
\hline - пасажир мотоциклу & - & - & $3 ; 0,7 \%$ & $3 ; 0,7 \%$ \\
\hline - водій скутера & - & - & $2 ; 0,5 \%$ & $2 ; 0,5 \%$ \\
\hline - пасажир скутера & $4 ; 0,9 \%$ & $5 ; 1,2 \%$ & $6 ; 1,5 \%$ & $1 ; ; 0,2 \%$ \\
\hline Падіння з висоти & $4 ; 0,9 \%$ & $1 ; 0,2 \%$ & - & $5 ; 1,1 \%$ \\
\hline Побутова травма & $22 ; 5,2 \%$ & $33 ; 7,8 \%$ & $370 ; 87,1 \%$ & $425 ; 100 \%$ \\
\hline Всього & & - & $1 ; 0,2 \%$ & $15 \%$ \\
\hline
\end{tabular}

Ізольована травма стегнової або великогомілкової кістки серед 450 актів СME, включених в дослідження, відзначалася лише в $22(5,2 \%)$ випадках. В інших $428(94,8 \%)$ актах СME була представлена політравма, в якій переважали поєднані ушкодження $(87,1 \%)$ табл. 1.

Ступінь тяжкості тілесних ушкоджень у випадках політравми 3 наявністю декількох поєднаних ушкоджень оцінювалася за характером самого важкого пошкодження. У постраждалих з відкритими та / або закритими переломами нижніх кінцівок більш важкими тілесними ушкодженнями вважалися: проникаючі пошкодження черепа; відкриті і закриті переломи кісток основи або зводу черепа; забій головного мозку важкого ступеня; забій головного мозку середнього ступеня зі стовбурної симптоматикою; клінічно значущі внутрішньочерепні крововиливи; проникаючі, відкриті і закриті ушкодження грудної клітини 3 наявністю загрозливого гемопнемоторакса та / або гемоперикарда; проникаючі, відкриті і закриті ушкодження живота 3 пошкодженням заочеревинних органів і / або із загрозливим гемоперитонеумом.
У разі політравми 3 множинними пошкодженнями верхніх і нижніх кінцівок в якості найбільш важкого розглядався перелом, що утворився у даного потерпілого під впливом найбільшої травмуючої сили. У цих випадках як саме тяжке тілесне ушкодження розцінювалися відкриті переломи стегнової кістки, потім - відкриті переломи великогомілкової кістки, далі - закриті переломи стегна i закриті переломи великогомілкової кістки.

Методи дослідження - ретроспективний аналіз, описова статистика.

Результати. Середній вік потерпілих, включених в дослідження, склав 42,1 $\pm 24,3$ роки (10 - 81 рік). Зазначалося переважання постраждалих чоловічої статі (68 \%).

Серед досліджених пошкоджень довгих кісток нижніх кінцівок найчастішими були переломи великогомілкової кістки. В цілому по групі, в порівнянні 3 аналогічними травмами стегнової кістки, відкриті і закриті переломи великогомілкової кістки в сумі реєструвалися в 2,2 рази частіше, відкриті переломи - в 10,3 рази, закриті переломи - в 1,7 рази частіше (табл. 2). 
Дорожньо-транспортний травматизм в даний час займає лідируюче місце в структурі нелетальної і летальної травми опорно-рухової системи (ОРС) у країнах 3 різним рівнем економічного розвитку [16]. Частіше за інших сегментів ОРС травмуються нижні кінцівки $[17,18]$, в яких, у свою чергу, переважають переломи гомілки [19]. Частота утворення відкритих i закритих переломів довгих трубчастих кісток нижніх кінцівок визначається силою i, відповідно, енергією травмуючого агента. У зв'язку з цим найбільш високоенергетичною травмою, з урахуванням анатомо-біомеханічних характеристик стегнової і великогомілкової кісток, є відкриті переломи стегна. Невелика кількість відкритих переломів даних кісток в нашому дослідженні пояснюється відносно невисокою швидкістю руху транспортних засобів - учасників ДТП, яка в більшості випадків не перевищувала 40 км / год.

Таблиия 2. Частота переломів стегнової та великогомілкової кістки в різних групах постраждалих

\begin{tabular}{|c|c|c|c|c|c|}
\hline \multirow{3}{*}{ Механізм травми } & \multicolumn{2}{|c|}{ Переломи стегна } & \multicolumn{2}{|c|}{ Переломи гомілки } & \multirow{3}{*}{ Всього } \\
\hline & закриті & відкриті & закриті & відкриті & \\
\hline & \multicolumn{4}{|c|}{$\mathrm{n}=425 ; 100 \%$} & \\
\hline \multicolumn{6}{|c|}{ Дорожньо-транспортні пригоди } \\
\hline - пішохід & $109 ; 25,6 \%$ & $6 ; 1,4 \%$ & $185 ; 43,5 \%$ & $69 ; 16,2 \%$ & $369 ; 86,8 \%$ \\
\hline $\begin{array}{l}\text { - водій легкового } \\
\text { автомобіля }\end{array}$ & $6 ; 1,5 \%$ & - & $6 ; 1,5 \%$ & $4 ; 0,9 \%$ & $16 ; 3,9 \%$ \\
\hline $\begin{array}{l}\text { - пасажир легкового } \\
\text { автомобіля }\end{array}$ & $5 ; 1,2 \%$ & $1 ; 0,2 \%$ & $3 ; 0,7 \%$ & $1 ; 0,2 \%$ & $10 ; 2,3 \%$ \\
\hline - водій мотоциклу & $1 ; 0,2 \%$ & - & $1 ; 0,2 \%$ & $2 ; 0,5 \%$ & $4 ; 0,9 \%$ \\
\hline - пасажир мотоциклу & - & - & - & $3 ; 0,7 \%$ & $3 ; 0,7 \%$ \\
\hline - водій скутера & - & - & $1 ; 0,2 \%$ & $1 ; 0,2 \%$ & $2 ; 0,5 \%$ \\
\hline - пасажир скутера & - & $1 ; 0,2 \%$ & - & - & $1 ; 0,2 \%$ \\
\hline Падіння з висоти & $4 ; 0,9 \%$ & - & $9 ; 2,1 \%$ & $2 ; 0,5 \%$ & $15 ; 3,5 \%$ \\
\hline Побутова травма & $1 ; 0,2 \%$ & - & $4 ; 0,9 \%$ & - & $5 ; 1,2 \%$ \\
\hline Всього & $126 ; 29,6 \%$ & $8 ; 1,9 \%$ & $209 ; 49,2 \%$ & $82 ; 19,2 \%$ & $425 ; 100 \%$ \\
\hline
\end{tabular}

Падіння 3 великої висоти (понад 3м) - ще один механізм утворення високоенергетичних відкритих переломів нижніх кінцівок $[19,20]$. У нашому дослідженні відзначалося падіння або 3 висоти власного зросту 3 доданим прискоренням, або 3 висоти до 3 м, що зумовило переважання закритих переломів стегнової та великогомілкової кісток.
Результати порівняльного ретроспективного аналізу актів судовомедичних експертиз щодо визначення ступеня тяжкості тілесних ушкоджень у потерпілих 3 відкритими і закритими переломами стегнової і великогомілкової кісток представлені в таблиці 3. 
Таблиия 3. Частота встановлення середньої тяжкості і тяжких тілесних ушкоджень у разі відкритих $і$ закритих переломів стегнової і великогомілкової кістки

\begin{tabular}{|c|c|c|c|c|}
\hline \multirow{2}{*}{$\begin{array}{c}\text { Встановлена ступінь тяжкості тілесних } \\
\text { ушкоджень }\end{array}$} & \multicolumn{2}{|c|}{ Переломи стегна } & \multicolumn{2}{|c|}{ Переломи гомілки } \\
\hline & закриті & відкриті & закриті & відкриті \\
\hline Первинна СМЕ & \multicolumn{4}{|c|}{$\mathrm{n}=170 ; 100 \%$} \\
\hline - тілесні ушкодження середньої тяжкості & $69 ; 40,6 \%$ & - & $61 ; 35,9 \%$ & - \\
\hline \multicolumn{5}{|l|}{ - тяжкі тілесні ушкодження за характером: } \\
\hline - травми нижньої кінцівки & - & $3 ; 1,8 \%$ & - & $28 ; 16,5 \%$ \\
\hline - поєднаної травми & $1 ; 0,6 \%$ & - & $4 ; 2,3 \%$ & $4 ; 2,3 \%$ \\
\hline Комісійна СМЕ & \multicolumn{4}{|c|}{$\mathrm{n}=185 ; 100 \%$} \\
\hline - тілесні ушкодження середньої тяжкості & $41 ; 22,2 \%$ & $1 ; 0,5 \%$ & $68 ; 36,7 \%$ & - \\
\hline \multicolumn{5}{|l|}{ - тяжкі тілесні ушкодження за характером: } \\
\hline - травми нижньої кінцівки & - & $2 ; 1,1 \%$ & - & $21 ; 11,4 \%$ \\
\hline - поєднаної травми & - & $2 ; 1,1 \%$ & $32 ; 17,2 \%$ & $14 ; 7,6 \%$ \\
\hline - за наслідками травми & - & - & $4 ; 2,2 \%$ & - \\
\hline Комплексна СМЕ & \multicolumn{4}{|c|}{$\mathrm{n}=70 ; 100 \%$} \\
\hline - тілесні ушкодження середньої тяжкості & $11 ; 15,7 \%$ & - & $27 ; 38,6 \%$ & - \\
\hline \multicolumn{5}{|l|}{ - тяжкі тілесні ушкодження за характером: } \\
\hline - травми нижньої кінцівки & - & - & - & $4 ; 5,7 \%$ \\
\hline - поєднаної травми & $4 ; 5,7 \%$ & - & $6 ; 8,6 \%$ & $11 ; 15,7 \%$ \\
\hline - за наслідками травми & - & - & $7 ; 10,0 \%$ & - \\
\hline \multirow{2}{*}{ Всього } & \multicolumn{4}{|c|}{$\mathrm{n}=425 ; 100 \%$} \\
\hline & $126 ; 29,6 \%$ & $8 ; 1,9 \%$ & $209 ; 49,2 \%$ & $82 ; 19,3 \%$ \\
\hline
\end{tabular}

Як випливає з таблиці 3, згідно 3 актами первинних CME, всі закриті переломи стегнової (40,6 \%) і великогомілкової $(35,9 \%)$ кісток віднесені до тілесних ушкоджень середнього ступеня тяжкості, а всі відкриті переломи цієї ж локалізації - до тяжких тілесних ушкоджень, що представляють небезпеку для життя потерпілого $(1,8$ \% i 16,5 \% відповідно) або за тяжкістю поєднаної черепно-мозкової травми $(0,6 \%$ i $2,3 \%$ відповідно). Такі результати є цілком закономірними, так як на момент проведення первинної CME (зазвичай в терміни, що не перевищують 1 міс. після травми) зрощення переломів даної локалізації ще не настає, наслідок травми невідомий.
Результати дослідження актів комісійних CME представляють іншу картину, так як одним з питань, поставлених для вирішення цією судово-медичною експертизою, $\epsilon$ визначення ступеня тяжкості тілесних ушкоджень за наслідками травми. Закриті переломи стегна $(22,2 \%)$ і гомілки $(36,7 \%)$ були віднесені до ушкоджень середнього ступеня, що $\epsilon$ стандартною експертною оцінкою для даного виду травми. Як небезпечні для життя тяжкі тілесні ушкодження були розцінені відкриті переломи стегна $(1,1 \%)$ і гомілки $(11,4$ \%). Процес консолідації цих переломів протікав без ускладнень; було досягнуто зрощення перелому без укорочення кінцівки. До тяжких 
тілесних ушкоджень за характером поєднаної черепно-мозкової травми, травми грудної клітини i травми живота були віднесені переважно переломи гомілки, відкриті $(7,6$ \%) i закриті $(17,2 \%)$. Звертають на себе увагу наступні результати комісійної СМЕ. У однієї постраждалої (пасажир легкового автомобіля) відкритий перелом діафіза стегнової кістки в середній третині 3 кожною раною довжіною $8 \mathrm{~cm}$ (перелом II типу) за наслідком травми був розцінений як пошкодження середнього ступеня тяжкості (0,5 \%). Також за наслідками травми у 4 (2,2 \%) постраждалих з закритими переломами проксимального епіметафіза великогомілкової кістки, що уповільнено зростаються, та стійкою контрактурою колінного суглоба i зниженням загальної працездатності більш ніж на 33\% дані переломи були віднесені до тяжких тілесних ушкоджень (табл. 3).

Під час комплексної СМЕ стандартна експертна оцінка у вигляді тілесних ушкоджень середнього ступеня тяжкості відносилася до закритих переломів стегна $(15,7 \%)$ і гомілки (38,6 \%). До тяжких тілесних ушкоджень за характером поєднаної черепномозкової травми і травми грудної клітини віднесені закриті переломи стегна $(5,7 \%)$, закриті $(8,6 \%)$ і відкриті $(15,7 \%)$ переломи гомілки. За результатами травми 3 втратою понад 33 \% загальної працездатності в якості тяжких тілесних ушкоджень розцінені 7 випадків (10 \%) закритих переломів проксимального епіметафіза і метадіафіза великогомілкової кістки зі сповільненою консолідацією та утворенням стійких контрактур колінного суглоба. Тяжкими ушкодженнями за характером травми i i наслідків оцінені 4 (5,7 \%) відкритих переломів великогомілкової кістки (табл. 3).

Слід зазначити, що в жодному 3 досліджених актів СМЕ при визначенні ступеня тяжкості тілесних ушкоджень у разі відкритого перелома стегнової або великогомілкової кістки не враховувався ні характер перелому відповідно до загальноприйнятої класифікації АО/АOT, ні ступінь пошкодження м'яких тканин за загальноприйнятою класифікацією Gustilo Anderson. Більш того, лише в 19 (4,5 \%) досліджених актах СME в заключному клінічному діагнозі вказувався тип відкритого перелому за Gustilo - Anderson. Іншими словами, під час визначення ступеня тяжкості тілесних ушкоджень у постраждалого 3 відкритим переломом нижньої кінцівки судово-медичний експерт не мав точної уяви щодо характеру перелому.

Як приклад СМЕ відкритого перелому гомілки наведемо таке клінічне спостереження. Постраждала В., 27 років, перебуваючи в стані алкогольного сп'яніння (вміст алкоголю в крові 1,75 \%о) при переході проїжджої частини в невстановленому місці на червоний сигнал світлофора в результаті наїзду легкового автомобіля отримала вдруге відкритий перелом великогомілкової кістки в c / 3, закритий перелом малогомілкової кістки в с / 3. Обидва переломи зрослися без вторинної деформації кінцівки. За результатами первинної СМЕ травма розцінена як тяжкі тілесні ушкодження; за результатами комплексної СМЕ за наслідками травми (через 14 міс. після травми) - також тяжкі тілесні ушкодження. Торкаючись тільки травматологічних аспектів даного ДТП, відзначимо, що результат даних переломів явно не дотягує до тяжких тілесних ушкоджень. Первинна CME формально, за існуючими в даний час «Правил ...» [15] віднесла вдруге відкритий неускладнений перелом (типу I за класифікацією GustiloAnderson [7]) до тяжких тілесних ушкоджень.

У зв'язку з цим виникає кілька питань до «Правил ...» [15]. До тяжких тілесних ушкоджень за критерієм небезпеки для життя віднесені відкриті діафізарні переломи стегнової, плечової і великогомілкової кісток як ізольована травма. Очевидно, небезпека для життя проявляється в гострій крововтраті 3 розвитком геморагічного шоку, які є супутніми до даних травм. Однак причини гострої крововтрати при переломах довгих трубчастих кісток потребують уточнення. 3 одного боку, джерелом кровотечі при діафізарних переломах $є$ внутрішньокісткові і періостальні судини, а також судини різного калібру, що кровопостачають пошкоджені м'язи. Така крововтрата не залежить істотно від виду перелому (відкритий, закритий) i може досягати 1,0-2,5 л при переломах стегна і 0,51,5 л при переломах плеча або кісток гомілки 
[21]. В цьому випадку неясно, чому саме відкриті переломи цієї локалізації відносяться до категорії небезпечних для життя.

3 іншого боку, існує можливість пошкодження магістральних судин 3 розвитком гострої крововтрати при відкритих переломах 3 масивним пошкодженням м'яких тканин типу IIIC i, в ряді випадків, IIIB. Тоді виникає закономірне питання про приналежність до таких травм відкритих переломів II і особливо I типу з невеликою або мінімальної шкірної раною, що не робить зазвичай негативного впливу на перебіг післятравматичного періоду i терміни зрощення перелому [22].

Слід зазначити, що відкриті переломи проксимального і дистального відділів великогомілкової кістки III типу розглядаються як більш важкі в порівнянні 3 діафізарними переломами внаслідок більш високої ймовірності розвитку інфекційних ускладнень у більших масивах пошкоджених м'яких тканин [18, 23].

Відкриті переломи є також фактором ризику незрощення кісткових фрагментів, що, крім функціональних обмежень, призводить до зловживання опіатами, алкоголем, розвитку депресії внаслідок хронічного больового синдрому [24]. Найвищий ризик незрощення доведено для відкритих переломів діафіза великогомілкової кістки внаслідок відсутності м'яких тканин по передній поверхні кістки і бідній васкуляризації [25]. До інших ускладнених наслідків відкритих переломів довгих трубчастих кісток належать регіональний больовий синдром у разі посиленої запальної відповіді на травму в поєднанні 3 нейрогіперсентізацією [26], а також ампутація нежиттєздатної кінцівки при переломах типу IIIB і IIIC [27]. Зазначені ускладнення безумовно погіршують функціональні результати i якість життя постраждалих 3 відкритими переломами нижніх кінцівок [12], але не є небезпечними для життя.

Висновки. Відкриті переломи довгих кісток нижніх кінцівок I i II типу за клінічним перебігом, лікувальними підходами, ризиком розвитку ускладнень суттєво відрізняються від відкритих переломів III типу. Гостра крововтрата i геморагічний шок, що розвиваються при переломах довгих трубчастих кісток в результаті пошкодження внутрішньокісткових, періостальних судин i судин м'язів, характерні як для відкритих, так і для закритих переломів. Описані в літературі ускладнені наслідки відкритих переломів нижніх кінцівок не $є$ небезпечними для життя. Виявлені в результаті даного дослідження тяжкі тілесні ушкодження за наслідками травми були переважно результатом близько- i внутрішньосуглобових переломів, що не зрослися, зі стійкою контрактурою суглоба. Перераховані вище факти свідчать про необхідність корекції «Правил визначення ступеня тяжкості тілесних ушкоджень» у разі відкритих переломів довгих трубчастих кісток i ïх диференційованого застосування при переломах різної складності з різним ступенем пошкодження м'яких тканин.

\section{Список літератури}

1. Weber CD, Hildebrand F, Kobbe P, Lefering R, Sellei RM, Pape H-C. Epidemiology of open tibia fractures in a population-based database: update on current risk factors and clinical implications. Eur J Trauma Emerg Surg. 2019;45:445-453 https://doi.org/10.1007/s00068-018-09169

2. Gumbel D, Matthes G, Napp M, Lange J, Hinz P, Spitzmüller R, Ekkernkamp A. Current management of open fractures: results from an online survey. Arch Orthop Trauma Surg. 2016;136:1663-1672. https://doi.org/10.1007/s00402-016-2566-x

3. Hoff WS, Bonadies JA, Cachecho R, Dorlac WC. East Practice Management Guidelines Work Group: update to practice management guidelines for prophylactic antibiotic use in open fractures. J Trauma. 2011;70(3):751754. doi:10.1097/TA.0b013e31820930e5

4. Metsemakers WJ, Reul M, Nijs S. The use of gentamicin-coated nails in complex open tibia fracture and revision cases: a retrospective analysis of a single centre case series and review of the literature. Injury. 2015;46(12):24332437. doi:10.1016/j.injury.2015.09.028

5. Court-Brown CM, Bugler KE, Clement ND, Duckworth AD, McQueen MM. The epidemiology of open fractures in adults. A 15-year review. Injury. 2012;43(6):891-897. doi:10.1016/j.injury.2011.12.007

6. Santos AL, Nitta CT, Boni G, Sanchez GT, Tamaoki MJS, Reis FB. Evaluation and comparison of open and closed tibia shaft fractures in a quaternary reference center. Acta Ortop Bras. 2018;26(3):194-7.DOI: http://dx.doi.org/10.1590/1413-785220182603184073

7. Gustilo RB, Anderson JT. Prevention of infection in the treatment of one thousand and twenty-five open fractures of long bones: retrospective and prospective analyses. J Bone Jt Surg Am. 1976;58(4):453-458.

8 . Penn-Barwell JG, Bennett PM, Fries CA, Kendrew JM, Mid- winter MJ, Rickard RF. Severe open tibial 
fractures in com- bat trauma: management and preliminary outcomes. Bone Jt J. 2013;95-b(1):101-105.

9. Papakostidis C, Kanakaris NK, Pretel J, Faour O, Morell DJ, Giannoudis PV. Prevalence of complications of open tibial shaft fractures stratified as per the GustiloAnderson classification. Injury. 2011;42(12):1408-1415.

10. Connelly CL, Bucknall V, Jenkins PJ, Court-Brown CM, McQueen MM, Biant LC. Outcome at 12 to 22 years of 1502 tibial shaft fractures. Bone Jt J. 2014;96-b(10):1370-7. https:// doi.org/10.1302/0301-620x.96b10.32914.

11. Wordsworth M, Lawton G, Nathwani D, Pearse M, Naique S, Dodds A, Donaldson $\mathrm{H}$ et al. Improving the care of patients with severe open fractures of the tibia: the effect of the introduction of Major Trauma Networks and national guidelines. Bone Jt J. 2016;98-b(3):420-424.

12. Mundy LR, Grier AJ, Weissler EH, Carty MJ, Pusic AL, Hollenbeck ST, Gage MJ. Patient-reported Outcome Instruments in Lower Extremity Trauma: A Systematic Review of the Literature Plast Reconstr Surg Glob Open 2019;7:e2218. Published online 3 May 2019; www.PRSGlobalOpen.com. doi: 10.1097/ GOX.0000000000002218.

13. Djahangiri A, Garofalo R, Chevalley F, Leyvraz PF, Wettstein M, Borens O, Schizas C et al. Closed and Open Grade I and II Tibial Shaft Fractures Treated by Reamed Intramedullary Nailing. Med Princ Pract 2006;15:293-298 DOI: $10.1159 / 000092993$

14. Briel M, Sprague S, Heels-Ansde D, Guyatt G, Bhandari M, Blackhouse G, Sanders D et al. Economic Evaluation of Reamed versus Unreamed Intramedullary Nailing in Patients with Closed and Open Tibial Fractures: Results from the Study to Prospectively Evaluate Reamed Intramedullary Nails in Patients with Tibial Fractures (SPRINT). Value in Health. 2011; 14(4):450-457. https://doi.org/10.1016/j.jval.2010.10.034.

15. Правила судово-медичного визначення ступеня тяжкості тілесних ушкоджень. Затверджено наказом Міністерства охорони здоров'я України від 17 січня 1995 року № 6.

16. Global status report on road safety 2018. Geneva: World Health Organization; 2018. Licence: CC BY- NC-SA 3.0 IGO. 403 p.

17. Григорьєва НВ, Власенко РО. Епідеміологія і фактори ризику переломів нижніх кінцівок (огляд літератури). Біль, суглоби, хребет. 2017; 7(3):127-138. DOI: https://doi.org/10.22141/2224-1507.7.3.2017.116868

18. Elniel AR, Giannoudis PV. Open fractures of the lower extremity: current management and clinical outcomes. EFORT Open Rev 2018;3:316-325. DOI: 10.1302/20585241.3.170072

19. Larsen P, Elsoe R, Hansen SH, et al. Incidence and epidemiology of tibial shaft fractures. Injury $2015 ; 46: 746-$ 50. doi: 10.1016/j.injury.2014.12.027

20. Jenkins PJ, Keating JF, Simpson AH. Fractures of the tibial shaft. Surgery 2010;28:489-93.

21. Курсов СВ, Никонов ВВ, Скороплет СН. Кровопотеря. Медицина невідкладних станів. 2019;1(96):7-21. DOI: 10.22141/22240586.1 .96 .2019 .158741 .
22. Zelle BA, Boni G. Safe surgical technique: intramedullary nail fixation of tibial shaft fractures. Patient Saf Surg 2015;9:40. doi: 10.1186/s13037-015-0086-1

23. Ryan SP, Boulton CL, O'Toole RV. Open Diaphyseal Tibia Fractures. In: Ed. by: Sethi M, Obremskey W, Jahangir A. Orthopedic Traumatology. Cham.: Springer; 2018. P. 287-302 https://doi.org/10.1007/978-3-319-733920_23

24. Santolini E, West R, Giannoudis PV. Risk factors for long bone fracture non- union: a stratification approach based on the level of the existing scientific evidence. Injury 2015;46(suppl 8):S8-S19. https://doi.org/10.1016/S00201383(15)30049-8

25. Calori GM, Albisetti W, Agus A, Iori S, Tagliabue L. Risk factors contributing to fracture non-unions. Injury 2007;38(suppl 2):S11-S18. https://doi.org/10.1016/S00201383(07)80004-0

26. Goh EL, Chidambaram S, Ma D. Complex regional pain syndrome: a recent update. Burns Trauma 2017;5:2. doi: 10.1186/s41038-016-0066-4

27. Cannada $1 \mathrm{~K}$, Melton DH, Deren ME, Hayda RA, Harvey EJ. Dealing with catastrophic outcomes and amputations in the mangled limb. J Orthop Trauma 2015;29(suppl 12):S39-S42. DOI: 10.1097/BOT.0000000000000468

\section{References}

1. Weber CD, Hildebrand F, Kobbe P, Lefering R, Sellei RM, Pape H-C. Epidemiology of open tibia fractures in a population-based database: update on current risk factors and clinical implications. Eur J Trauma Emerg Surg. 2019;45:445-453 https://doi.org/10.1007/s00068-018-09169

2. Gumbel D, Matthes G, Napp M, Lange J, Hinz P, Spitzmüller R, Ekkernkamp A. Current management of open fractures: results from an online survey. Arch Orthop Trauma Surg. 2016;136:1663-1672. https://doi.org/10.1007/s00402-016-2566-X

3. Hoff WS, Bonadies JA, Cachecho R, Dorlac WC. East Practice Management Guidelines Work Group: update to practice management guidelines for prophylactic antibiotic use in open fractures. J Trauma. 2011;70(3):751754. doi:10.1097/TA.0b013e31820930e5

4. Metsemakers WJ, Reul M, Nijs S. The use of gentamicin-coated nails in complex open tibia fracture and revision cases: a retrospective analysis of a single centre case series and review of the literature. Injury. 2015;46(12):24332437. doi:10.1016/j.injury.2015.09.028

5. Court-Brown CM, Bugler KE, Clement ND, Duckworth AD, McQueen MM. The epidemiology of open fractures in adults. A 15-year review. Injury. 2012;43(6):891-897. doi:10.1016/j.injury.2011.12.007

6. Santos AL, Nitta CT, Boni G, Sanchez GT, Tamaoki MJS, Reis FB. Evaluation and comparison of open and closed tibia shaft fractures in a quaternary reference center. Acta Ortop Bras. 2018;26(3):194-7. DOI: http://dx.doi.org/10.1590/1413-785220182603184073

7. Gustilo RB, Anderson JT. Prevention of infection in the treatment of one thousand and twenty-five open fractures of long bones: retrospective and prospective analyses. J Bone Jt Surg Am. 1976;58(4):453-458. 
8. Penn-Barwell JG, Bennett PM, Fries CA, Kendrew JM, Mid- winter MJ, Rickard RF. Severe open tibial fractures in com- bat trauma: management and preliminary outcomes. Bone Jt J. 2013;95-b(1):101-105.

9. Papakostidis C, Kanakaris NK, Pretel J, Faour O, Morell DJ, Giannoudis PV. Prevalence of complications of open tibial shaft fractures stratified as per the GustiloAnderson classification. Injury. 2011;42(12):1408-1415.

10. Connelly CL, Bucknall V, Jenkins PJ, Court-Brown CM, McQueen MM, Biant LC. Outcome at 12 to 22 years of 1502 tibial shaft fractures. Bone Jt J. 2014;96-b(10):1370-7. https:// doi.org/10.1302/0301-620x.96b10.32914.

11. Wordsworth M, Lawton G, Nathwani D, Pearse M, Naique $\mathrm{S}$, Dodds A, Donaldson $\mathrm{H}$ et al. Improving the care of patients with severe open fractures of the tibia: the effect of the introduction of Major Trauma Networks and national guidelines. Bone Jt J. 2016;98-b(3):420-424.

12. Mundy LR, Grier AJ, Weissler EH, Carty MJ, Pusic AL, Hollenbeck ST, Gage MJ. Patient-reported Outcome Instruments in Lower Extremity Trauma: A Systematic Review of the Literature Plast Reconstr Surg Glob Open 2019;7:e2218. Published online 3 May 2019; www.PRSGlobalOpen.com. doi: 10.1097/ GOX.0000000000002218.

13. Djahangiri A, Garofalo R, Chevalley F, Leyvraz PF, Wettstein M, Borens O, Schizas C et al. Closed and Open Grade I and II Tibial Shaft Fractures Treated by Reamed Intramedullary Nailing. Med Princ Pract 2006;15:293-298 DOI: 10.1159/000092993

14. Briel M, Sprague S, Heels-Ansde D, Guyatt G, Bhandari M, Blackhouse G, Sanders D et al. Economic Evaluation of Reamed versus Unreamed Intramedullary Nailing in Patients with Closed and Open Tibial Fractures: Results from the Study to Prospectively Evaluate Reamed Intramedullary Nails in Patients with Tibial Fractures (SPRINT). Value in Health. 2011; 14(4):450-457. https://doi.org/10.1016/j.jval.2010.10.034.

15. Rules of forensic determination of the severity of bodily injuries. Approved by the order of the Ministry of Health of Ukraine of January 17, 1995 No 6. (Ukrainian)

16. Global status report on road safety 2018. Geneva: World Health Organization; 2018. Licence: CC BY- NC-SA 3.0 IGO. 403 p.

\section{TO THE QUESTION OF ESTABLISHING THE SEVERITY OF BODILY INJURIES IN OPEN FRACTURES OF THE LOWER LIMBS}

\author{
Sokol Viacheslav, Olkhovsky Vasil, Kolesnichenko Vira
}

Mail for correspondence: 28111957vk@gmail.com

Summary: Currently existing "Rules for determining the severity of bodily injuries" do not correspond to the modern classification, the level of knowledge about clinical course and outcomes of open fractures of the lower extremities. Purpose - to conduct a comparative retrospective analysis of forensic medical examinations results to determine the severity of bodily injuries in victims with open and closed fractures of the lower extremities. Material and methods. Research material - 425 acts (170 primary, 185 commissions, 70 complex) forensic medical examinations of victims with fractures of the femur and / or tibia, performed in the Kharkiv Regional Bureau of Forensic Medicine for the period February - June 2018. Research methods - retrospective analysis, descriptive statistics. Results. It was found that both at the time of injury and in the event of its (injury) consequences in victims with a leading injury of the lower extremities, open fractures of the femur and tibia are assessed as severe bodily injuries without taking into account the nature of the fracture and the degree of damage 
to soft tissues (according to generally accepted classifications), although these data determine the features of treatment measures and the prognosis of trauma at the prehospital and hospital stages. Conclusions. Open fractures of long bones of the lower extremities of type I and II in clinical course, treatment approaches, a risk of complications differ significantly from open fractures of type III. Acute blood loss and hemorrhagic shock, which develop in fractures of long tubular bones as a result of damage of intraosseous, periosteal and muscle vessels, are characteristic of both open and closed fractures. The complicated consequences of open fractures of the lower extremities described in the literature are not life-threatening. The severe bodily injuries revealed as a result of this study were mainly the result of non-union periarticular and intra-articular fractures with persistent joint contracture. The above facts indicate the need to correct the "Rules for determining the severity of injuries" in the case of open fractures of long tubular bones and their differentiated use in fractures of varying complexity with varying degrees of soft tissue damage.

Key words: open fracture of the lower extremities, forensic medical examination, severity of bodily injuries, outcome of trauma

Information about author

Sokol Vyacheslav, MD, PhD, Assoc. Prof. of Forensic Medicine, Medical Law named prof. M. S. Bokarius, Kharkiv National Medical University, st. Dmytrivska 14/16, Kharkiv, 61052

e-mail: sokol_vk@ukr.net

https://orcid.org/0000-0002-8892-1765
Olkhovsky Vasyl, MD, PhD, Full Prof. of the Department of Forensic Medicine, Medical Law. zasl. prof. M. S. Bocarius. Kharkiv National Medical University, st. Dmytrivska 14/16, Kharkiv, 61052 e-mail: prof_olhovsky@ukr.net https://orcid.org/0000-0003-2843-2692
Kolesnichenko Vira, MD, PhD, Full Prof. of the Department of Surgical Diseases, Operative Surgery and Topographic Anatomy, Doctor of Medical Sciences, V. N. Karazin Kharkiv National University, School of Medicine, 6, Svobody Square, Kharkiv, Ukraine, 61022

e-mail: 28111957vk@gmail.com https://orcid.org/0000-0003-0503-9732

\title{
К ВОПРОСУ ОБ УСТАНОВЛЕНИИ СТЕПЕНИ ТЯЖЕСТИ ТЕЛЕСНЫХ ПОВРЕЖДЕНИЙ ПРИ ОТКРЫТЫХ ПЕРЕЛОМАХ НИЖНИХ КОНЕЧНОСТЕЙ
}

\author{
Sokol Viacheslav, Olkhovsky Vasil, Kolesnichenko Vira
}

Почта для переписки: 28111957vk@gmail.com

\begin{abstract}
Резюме: Существуюшие в настоящее время «Правила определения степени тяжести телесных повреждений» не соответствуют современной классификации, уровню знаний о клиническом течении и исходах открытых переломов нижних конечностей. Цель - провести сравнительный ретроспективный анализ результатов судебно-медицинских экспертиз по определению степени тяжести телесных повреждений у пострадавших с открытыми и закрытыми переломами нижних конечностей. Материаль и методы. Материал исследования - 425 актов (170 первичных, 185 комиссионных, 70 комплексных) судебно-медицинских экспертиз пострадавщих с переломами бедренной и / или большебериовой костей, произведенных в Харьковском областном бюро судебно-медицинской экспертизы за период февраль - июнь 2018 года. Методы исследования - ретроспективньий анализ, описательная статистика. Результаты. Установлено, что как на момент травмы, так и в случае ее (травмы) последствий у пострадавших с ведущей травмой нижних конечностей открытые переломы бедренной и большебериовой костей оцениваются как тяжкие телесные повреждения без учета характера перелома и степени повреждения мягких тканей (по общепринятым классификачиям), хотя эти данные определяют особенности лечебных мероприятий и прогноза травмы на догоспитальном и госпитальном этапах. Выводы. Открытые переломы длинных костей нижних конечностей I и II типа по клиническому течению, лечебными подходами, риску развития осложнений существенно отличаются от открытых переломов III типа. Необходима разработка критериев дифференцированной судебномедииинской экспертной оценки открытых переломов нижних конечностей на основе современных знаний о механогенезе открытой травмы, ее клиническом течении и исходах.
\end{abstract}

Ключевые слова: открытый перелом нижних конечностей, судебно-медицинская экспертиза, степень тяжести телесных повреждений, исход травмы

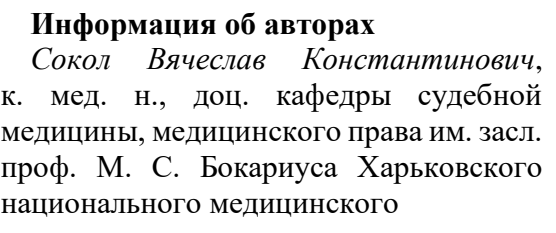

Информация об авторах

к. мед. н., доц. кафедры судебной медицины, медицинского права им. засл. национального медицинского университета, ул. Дмитриевская 14/16,

Харьков, 61052

e-mail: sokol_vk@ukr.net

https://orcid.org/0000-0002-8892-1765

Ольховский Василий Алексеевич,

д. мед. н., проф. кафедры судебной медицины, медицинского права им. засл. проф. М. С. Бокариуса Харьковского национального медицинского университет, ул. Дмитриевская 14/16, Харьков, 61052 e-mail: prof_olhovsky@ukr.net 
Actual problems of modern medicine. Issue 6, 2020

https://orcid.org/0000-0003-2843-2692

Колесниченко Вера Анатольевна, д. мед. н., проф. кафедры хирургических болезней, оперативной хирургии и топографической

Харьковского

анатомии

национального

университету имени В. Н. Каразина,

площадь Свободы 6, Харьков, 61022 e-mail: 28111957vk@gmail.com

https://orcid.org/0000-0003-0503-9732

Conflicts of interest: author has no conflict of interest to declare.

Конфлікт інтересів: відсутній.

Конфликт интересов: отсутствует. 


\title{
ВІДНОШЕННЯ НЕЙТРОФІЛІВ ДО ЛІМФОЦИТІВ У ДІАГНОСТИЦІ ВІСЦЕРО- ВІСЦЕРАЛЬНОЇ КАРДІОНЕЙРОПАТІЇ У ПАЦІЕНТІВ 3 УРАЖЕННЯМИ ЖОВЧНОГО MIXУPA
}

\author{
Стрільчук Л. М.
}

Пошта для листування: larysa.stril4uk@ukr.net

\begin{abstract}
Резюме. Відношення нейтрофілів до лімфочитів, або індекс «нейтрофіли/лімфоцити» (ІНЛ) відображсє активність системного неспецифічного запалення та відповіді імунної системи. На ІНЛ може впливати зміна стану жовчного міхура. 3 метою оцінити можливості використання ІНЛ для визначення стану серия у діагностииі вісиеро-вісиеральної кардіонейропатії залежно від стану жовчного міхура у пацієнтів з кардіоревматологічними патологічними станами проаналізовані результати обстеження 506 стаціонарних пацієнтів з кардіоревматологічними хворобами, яких залежно від стану жовчного міхура було поділено на групи: інтактний; сладж, поліпи та холестероз; перегини та деформації тіла жовчного міхура; деформації шийки та сонографічні ознаки перенесеного холециститу; холелітіаз; холеиистектомія в анамнезі. Встановлено, що отримані у даному дослідженні рівні перевищують значення здорових осіб у наших попередніх дослідженнях $(1,8 \pm 0,46)$ та дані літератури $(1,65-1,86)$. IНЛ залежав від стану жовчного міхура: максимальні значення завжди супроводжували патологічні зміни останнього. В умовах активної запальної фази ревматологічних хвороб ІНЛ був вищим, ніж при стабільних та гострих формах ішемічної хвороби серия. Кореляиії ІНЛ залежали від стану жовчного міхура. ІНЛ асоиіювався з віком та частотою сериевих скорочень, гострофазовими показниками запалення, ендогенної інтоксикаиії, ичитолізу та структурними характеристиками серия (камери, стінки, фракиія викиду). Висновки: ІНЛ був вищим за умов активного запального процесу при геморагічному васкуліті $(3,66)$ та ревматичній гарячиі $(3,24)$, ніж при стабільних формах ішемічної хвороби серия $(2,47)$ та інфаркті міокарда $(1,85)$, усі р<0,05). Незважсаючи на нозологію, значення IНЛ залежало від стану жовчного міхура і максимальним завжди було за умов змін його змін. Враховуючи велику кількість кореляцій з клінічними $і$ лабораторними показниками, а також результатами інструментальних обстежень, ІНЛ можна використовувати для діагностики вісиеро-вісиеральної кардіонейропатії.
\end{abstract}

Ключові слова: відношення нейтрофілів до лімфоцитів, ішемічна хвороба серця, стан жовчного міхура, вісцеро-вісцеральна кардіонейропатія

\footnotetext{
Інформація про авторів

Стрільчук Лариса Миколаївна,

к. мед. н., доцент кафедри терапії № 1 , медичної діагностики та гематології і трансфузіології Львівського
}

Вступ. Незважаючи на впровадження високотехнологічних методик обстежень, сучасна система охорони здоров'я, особливо первинна ланка, мусить оперувати доступними методами оцінки перебігу хвороби для визначення стратегії та тактики лікування. Таку додаткову інформацію можна отримати 3 інтегральних гематологічних індексів, серед яких сучасні науковці виділяють відношення нейтрофілів до лімфоцитів (neutrophils to lymphocytes ratio, iндекс «нейтрофіли/лімфоцити», ІНЛ), яке відображає активність двох протилежних універсальних патогенетичних механізмів - системного неспецифічного запалення та обмежувальної e-mail: larysa.stril4uk@ukr.net https://orcid.org/0000-0001-7077-2610 ім. Данила Галицького, вул. Пекарська,

69, Львів, Україна, 79010 стресової відповіді імунної системи [1]. ІНЛ, що використовується при злоякісних пухлинах різної локалізації, запаленнях та інших патологіях в отоларингології, неврології, психіатрії, виявився інформативним i в кардіології. Проведений минулого року метааналіз 241 публікації за участю понад 12 тис. пацієнтів показав, що ІНЛ корелював 3 важкістю хронічної серцевої недостатності, короткочасним та тривалим прогнозом ії перебігу; зростання ІНЛ виявилося незалежним предиктором госпітальної та загальної смертності, повторної госпіталізації, ефективності інвазивних методів протиаритмічної та реваскуляризаційної терапії [2]. За нашими попередніми даними, 
зростання ІНЛ більше 3,0, що характерно для реакції стресу, асоціювалось із зростанням функціонального класу серцевої недостатності, дилятацією лівого шлуночка (ЛШ), схильністю до тромбоутворення і було предиктором несприятливого перебігу хронічної ішемічної хвороби серця (IXC) [3].

На ІНЛ можуть впливати гіперхолестеролемія, метаболічний синдром, цукровий діабет, артеріальна гіпертензія [4]. Крім того, зміна стану жовчного міхура (ЖМ) через вісцеро-вісцеральні рефлекси здатна впливати на роботу серця $[5,6]$ i супроводжуватись змінами ІНЛ $[7,8]$, що слід враховувати клініцисту. Щодо використання ІНЛ для прогнозу біліарних уражень, наукові публікації стосуються виключено злоякісних пухлин ЖМ та гострих станів, які підлягали хірургічному втручанню. На думку науковців, розмежувальне значення ІНЛ, перевищення якого має несприятливе значення, становить для усіх гострих холециститів 4,1, для холециститів легкого перебігу - 3,25, а важкого $-4,17[7,8]$. Таким чином, у реальній клінічній практиці діагностичні та прогностичні можливості ІНЛ використовуються не повністю, що зумовило актуальність та доцільність нашого дослідження.

Мета: оцінити можливості використання IНЛ для визначення стану серця у діагностиці вісцеро-вісцеральної кардіонейропатії залежно від стану ЖМ у пацієнтів 3 кардіоревматологічною патологією.

\section{Матеріали та методи дослідження}

Ретроспективно проаналізовані результати обстеження 506 стаціонарних пацієнтів 3 кардіоревматологічними хворобами, які обстежувались та лікувались у 5 медичних закладах м. Львова: 339 осіб з IXC (гострий інфаркт міокарда (IM), n=142; нестабільна стенокардія (HC), $\mathrm{n}=116 ;$ стабільна стенокардія (CC) та постінфарктний кардіосклероз, $\mathrm{n}=81$ ) та 167 ревматологічних пацієнтів (геморагічний васкуліт (ГВ), n=75; ревматична гарячка (РГ), $\mathrm{n}=58$; хронічна ревматична хвороба серця з вадами (ХРХC); $\mathrm{n}=34)$. Залежно від сонографічно визначеного стану ЖМ, пацієнтів було поділено на 6 груп: інтактний ЖМ (Г0); сладж, згущення жовчі, поліпи та холестероз (Г1); перегини та деформації тіла ЖМ (Г2); деформації шийки та сонографічні ознаки перенесеного холециститу (ГЗ); холелітіаз (Г4); холецистектомія (ХЕ) в анамнезі (Г5). Критеріями виключення слугували печінкова, ниркова чи дихальна недостатність; серцева недостатність IV функціонального класу; онкологічні процеси; вагітність; анемія (середньотяжка та тяжка); розлади психіки та поведінки. Пацієнти були обстежені відповідно до нормативних документів за діагностованими нозологіями. Дослідження відповідало засадам Гельсінської Декларації Всесвітньої Медичної Асоціації щодо етичних принципів проведення наукових медичних досліджень за участю людини (1964, 2004, 2013) та Наказам МО3 України №690 (2009), №944 (2009) та №616 (2012). Цифрові дані опрацьовані статистично 3 використанням методів альтернативної мінливості, ранкінгу; міжгрупові різниці визначені за Стьюдентом; кореляції оцінені за Спірменом та Пірсоном (кореляції зі складниками самого індексу до уваги не брали); за поріг істотності прийнято $\mathrm{p}<0,05$.

\section{Результати та їх обговорення}

Визначення ІНЛ за нозологіями показало, що його значення були більшими за умов активного запального процесу при ГВ $(3,66 \pm 0,41)$ та РГ $(3,24 \pm 0,32)$, істотно перевищуючи показники для стабільних форм IXC $(2,47 \pm 0,20$, обидва $\mathrm{p}<0,05)$ та IXC, IM $(1,85 \pm 0,15$, обидва $\mathrm{p}<0,05)$. При IXC, НC та XPXC значення складали $2,91 \pm 0,15$ та $3,12 \pm 0,48$. Отримані нами рівні перевищують значення здорових осіб у наших попередніх дослідженнях $(1,8 \pm 0,46)$ [9]) та дані P. Forget та співавт. (2017) $(1,65-1,86)$ [10]. ІНЛ залежав також від стану ЖМ, причому, незважаючи на нозологію, максимальні значення завжди були за умов патологічних змін ЖМ: сладжу (при РГ), перегину тіла (при IXC, IM), ознаках перенесеного холециститу (при IXC, НC), холелітіазу (при IXC, СC), ХЕ в анамнезі (при ГВ) (табл. 1). 
Табличя 1. ІНЛ у кардіоревматологічних пацієнтів залежно від стану жовчного міхура

\begin{tabular}{|c|c|c|c|c|c|c|}
\hline Нозологія & $\begin{array}{c}\text { Група } 0 \\
\text { (інтактний } \\
\text { ЖМ) }\end{array}$ & $\begin{array}{l}\text { Група } 1 \\
\text { (сладж, } \\
\text { поліпи) }\end{array}$ & $\begin{array}{c}\text { Група } 2 \\
\text { (перегин } \\
\text { тіла) }\end{array}$ & $\begin{array}{c}\text { Група } 3 \\
\text { (ознаки } \\
\text { холециститу) }\end{array}$ & $\begin{array}{c}\text { Група } 4 \\
\text { (холелітіаз) }\end{array}$ & $\begin{array}{c}\text { Група 5 } \\
\text { (ХЕ в } \\
\text { анамнезі) }\end{array}$ \\
\hline $\begin{array}{c}\text { IXC, IM, } \\
\mathrm{n}=142\end{array}$ & $\begin{array}{l}1,38 \pm 0,07 \\
\mathrm{p}_{0-5}<0,05\end{array}$ & $\begin{array}{l}1,60 \pm 0,12 \\
\mathrm{p}_{1-4}<0,05\end{array}$ & $2,48 \pm 0,65$ & 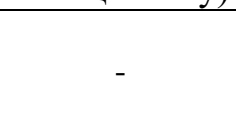 & $\begin{array}{l}1,91 \pm 0,08 \\
\mathrm{p}_{0-4}<0,01 \\
\mathrm{p}_{1-4}<0,05\end{array}$ & $\begin{array}{l}1,94 \pm 0,23 \\
\mathrm{p}_{0-5}<0,05\end{array}$ \\
\hline $\begin{array}{c}\mathrm{IXC}, \mathrm{HC} \\
\mathrm{n}=116\end{array}$ & $2,77 \pm 0,18$ & $\begin{array}{c}2,54 \pm 0,12 \\
\mathrm{p}_{1-3}<0,05\end{array}$ & $2,72 \pm 0,63$ & $\begin{array}{c}3,84 \pm 0,55 \\
\mathrm{p}_{1-3}<0,05\end{array}$ & $2,78 \pm 0,20$ & $3,01 \pm 0,39$ \\
\hline $\begin{array}{l}\text { Стабільна } \\
\text { IXC, } n=81\end{array}$ & $2,28 \pm 0,41$ & $2,61 \pm 1,02$ & $1,99 \pm 0,14$ & $2,39 \pm 0,48$ & $\begin{array}{c}3,33 \pm 0,54 \\
\mathrm{p}_{4-5}<0,05\end{array}$ & $\begin{array}{l}1,92 \pm 0,22 \\
\mathrm{p}_{4-5}<0,05\end{array}$ \\
\hline$\Gamma \mathrm{B}, \mathrm{n}=75$ & $3,97 \pm 0,85$ & $\begin{array}{l}2,47 \pm 0,30 \\
\mathrm{p}_{1-2}<0,05\end{array}$ & $\begin{array}{l}3,37 \pm 0,28 \\
\mathrm{p}_{1-2}<0,05\end{array}$ & $3,69 \pm 1,00$ & $4,03 \pm 1,17$ & $4,29 \pm 1,75$ \\
\hline $\mathrm{P} \Gamma, \mathrm{n}=58$ & $3,07 \pm 0,26$ & $4,18 \pm 1,55$ & $2,49 \pm 0,39$ & $3,48 \pm 0,61$ & $3,30 \pm 0,84$ & - \\
\hline $\mathrm{XPXC}, \mathrm{n}=34$ & $2,76 \pm 0,50$ & - & - & $3,00 \pm 1,69$ & $3,00 \pm 0,94$ & - \\
\hline Середній ранг & $\begin{array}{l}2,00 \pm 0,36 \\
\mathrm{p}_{0-3}<0,05 \\
\mathrm{p}_{0-4}<0,05\end{array}$ & $3,60 \pm 0,87$ & $\begin{array}{l}2,20 \pm 0,73 \\
\mathrm{p}_{2-3}=0,07\end{array}$ & $\begin{array}{l}4,00 \pm 0,63 \\
\mathrm{p}_{0-3}<0,05 \\
\mathrm{p}_{2-3}=0,07\end{array}$ & $\begin{array}{c}3,56 \pm 0,53 \\
p_{0-4}<0,05\end{array}$ & $4,00 \pm 1,08$ \\
\hline
\end{tabular}

Проведений ранкінг ІНЛ серед усіх обстежених показав, що максимальні значення виявлялись за умов наявних ознак перенесеного холециститу та 3 XЕ в анамнезі (табл.1), а усі значення чітко поділялися на 2 групи: інтактний ЖМ і перегин його тіла та усі інші патологічні стани - сладж, ознаки перенесеного холециститу, холелітіаз та XЕ в анамнезі (рис.

1).

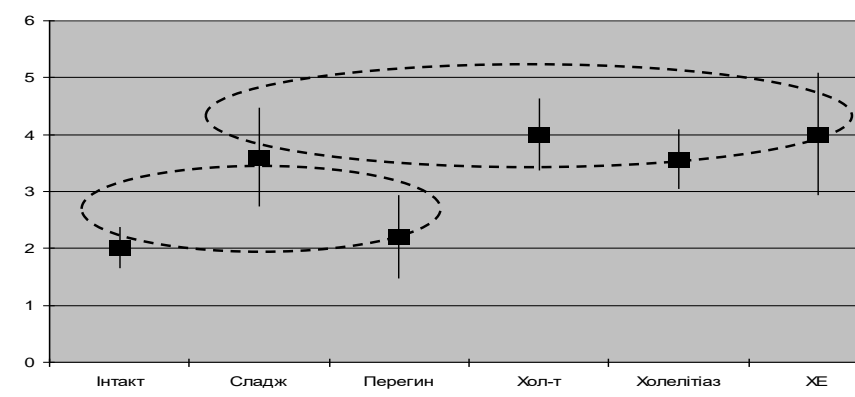

Рис. 1. Ранкінг значень ІНЛ серед 506 кардіоревматологічних паичієнтів

Виявлені за кореляційним аналізом зв'язки ІНЛ також залежали від стану ЖМ. За умов інтактного ЖМ ІНЛ зростав із віком пацієнтів (у групах IXC, CC та РГ), що слід брати до уваги у геріатричних пацієнтів (табл. 2). Другу найчисленнішу групу кореляцій утворювали зв’язки з показниками активності запалення: 3 швидкістю осідання еритроцитів (ШОЕ) (IXC, НС; РГ), С-реактивним протеїном (СРП) (при IXC, HC), лейкоцитами (ГВ) та моноцитами крові (IXC, IM; IXC, НC; РГ). До третьої групи за чисельністю можна віднести кореляції 3 структурними показниками серця - розмірами правого шлуночка (IXC, $\mathrm{CC}$ ), лівого передсердя (IXC, CC; РГ), лівого шлуночка у діастолу (РГ), товщиною міжшлуночкової перетинки (ГВ) та задньої стінки лівого шлуночка (ГВ). Однакова кількість зв'язків зафіксована 3 вираженістю ендогенної інтоксикації (за креатиніном та сечовиною; IXC, CC) та функціональним станом печінки (за аспартатамінотранферазою (АСТ) [РГ] та індексом де Рітіса [IXC, CC]) (табл. 2). Звертає на себе увагу істотна кореляція ІНЛ 3 розрахунковим параметром ліпідного метаболізму - відношенням моноцитів до ліпопротеїнів високої щільності (М/ЛПВЩ) (IXC, HC), яке вважається чутливим індикатором як запалення, так i окисного стресу та ендотеліальної дисфункції, незалежним предиктором тяжкого перебігу IXC та ймовірності майбутніх кардіоваскулярних подій [11]. 
Таблиия 2. Істотні кореляиії ІНЛ у кардіоревматологічних пацієнтів з інтактним станом жовчного міхура, сладжем і перегином ЖМ

\begin{tabular}{|c|c|c|c|c|c|}
\hline Нозологія & Складові & $\mathbf{r}$ & Нозологія & Складові & $\mathbf{r}$ \\
\hline \multicolumn{3}{|c|}{ Інтактний } & \multicolumn{3}{|c|}{ Сладж } \\
\hline \multirow{5}{*}{$\begin{array}{l}\text { IXC, IM } \\
\text { IXC, HC }\end{array}$} & ІНЛ-моноцити & 0,51 & \multirow{3}{*}{ IXC, IM } & ІНЛ-лейкоцити & 0,46 \\
\hline & ІНЛ-моноцити & 0,35 & & ІНЛ-ШОЕ & 0,41 \\
\hline & ІНЛ-ШОЕ $(* p=0,07)$ & $0,32 *$ & & ІНЛ-БЛП & $-0,41$ \\
\hline & ІНЛ- М/ЛПВЩ & 0,43 & \multirow{5}{*}{$\begin{array}{l}\text { Геморагічний } \\
\text { васкуліт }\end{array}$} & $\begin{array}{l}\text { ІНЛ-правий } \\
\text { шлуночок }\end{array}$ & 0,64 \\
\hline & ІНЛ-СРП & 0,40 & & ІНЛ-ЛШ, діастола & 0,80 \\
\hline \multirow{6}{*}{$\begin{array}{l}\text { Стабільні } \\
\text { форми IXC }\end{array}$} & ІНЛ-вік пацієнтів & 0,59 & & ІНЛ-аорта & 0,65 \\
\hline & $\begin{array}{l}\text { ІНЛ-правий } \\
\text { шлуночок }\end{array}$ & 0,71 & & ІНЛ-еритроцити & 0,78 \\
\hline & ІНЛ-ліве передсердя & 0,77 & & ІНЛ-гемоглобін & 0,66 \\
\hline & ІНЛ-індекс де Рітіса & 0,63 & $\begin{array}{l}\text { Ревматична } \\
\text { гарячка }\end{array}$ & ІНЛ-моноцити & 0,83 \\
\hline & ІНЛ-креатинін & 0,73 & \multicolumn{3}{|c|}{ Перегин тіла ЖМ } \\
\hline & ІНЛ-сечовина & 0,62 & \multirow{4}{*}{$\begin{array}{l}\text { IXC, IM } \\
\text { IXC, HC }\end{array}$} & ІНЛ-глюкоза & 0,49 \\
\hline \multirow{3}{*}{$\begin{array}{l}\text { Геморагічний } \\
\text { васкуліт }\end{array}$} & ІНЛ-МШП & 0,76 & & IНЛ-АСТ & 0,84 \\
\hline & $\begin{array}{l}\text { ІНЛ-задня стінка } \\
\text { ЛШ }\end{array}$ & 0,78 & & ІНЛ-АЛТ & 0,93 \\
\hline & $\begin{array}{l}\text { ІНЛ-лейкоцити } \\
\text { крові }\end{array}$ & 0,64 & & $\begin{array}{l}\text { ІНЛ-фракція } \\
\text { викиду }\end{array}$ & $-0,85$ \\
\hline \multirow[b]{3}{*}{$\begin{array}{l}\text { Ревматична } \\
\text { гарячка }\end{array}$} & ІНЛ-вік пацієнтів & 0,69 & \multirow[b]{2}{*}{$\begin{array}{l}\text { Ревматична } \\
\text { гарячка }\end{array}$} & ІНЛ-вік $(p=0,06)$ & $0,71 *$ \\
\hline & $\begin{array}{l}\text { ІНЛ- ліве } \\
\text { передсердя }\end{array}$ & 0,51 & & $\begin{array}{l}\text { ІНЛ-ліве } \\
\text { передсердя }\end{array}$ & 0,80 \\
\hline & $\begin{array}{l}\text { ІНЛ-лівий } \\
\text { шлуночок }\end{array}$ & 0,47 & \multicolumn{3}{|c|}{ 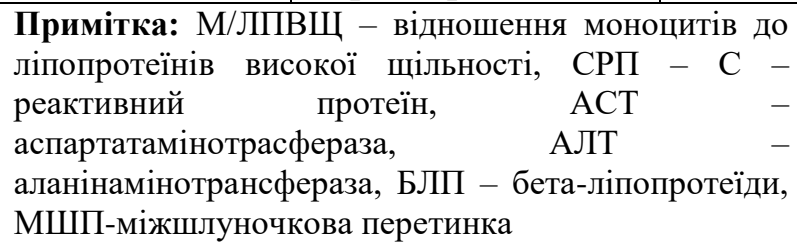 } \\
\hline
\end{tabular}

Серед пацієнтів зі сладжем зв'язки ІНЛ з параметрами запалення були представлені кореляціями з лейкоцитами та ШОЕ (IXC, IM), моноцитами (РГ); 3 структурнофункціональними параметрами серця - 3 розмірами правого та лівого шлуночків, аорти (ГВ), а також з бета-ліпопротеїдами (IXC, IM) та показниками червоного паростка крові еритроцитами та гемоглобіном (ГВ) (табл. 2). Для пацієнтів з перегином ЖМ, у яких, як було вказано вище, ІНЛ був невеликим, виявлено лише п'ять істотних кореляцій. Збільшуючись також із віком пацієнтів, ІНЛ змінювався паралельно трансаміназам (IXC, НC), глюкозі крові натще (IXC, IM), розміру лівого передсердя, а також обернено корелював 3 фракцією викиду (IXC, НC; РГ) (табл. 2).
Серед пацієнтів 3 ознаками перенесеного холециститу ІНЛ корелював 3 активністю запалення за лейкоцитами (ГВ), серомукоїдами (IXC, HC), загальним фібриногеном (IXC, HC; РГ), практично 3 усіма структурними параметрами серця - товщиною міжшлуночкової перетинки (IXC, НC) та задньої стінки ЛШ (IXC, НC), розмірами лівого передсердя (IXC, CC; ГВ), правого шлуночка (ГВ), лівого шлуночка у діастолу (РГ), а також із станом печінки за АСТ та індексом де Рітіса $(\mathrm{PГ})$, глюкозою крові натще (РГ), гемоглобіном та еритроцитами (ГВ). Що стосується клінічних ознак, зафіксована тенденція до зростання ІНЛ паралельно зростанню частоти серцевих скорочень (РГ) (табл. 3). 
Табличя 3. Істотні корелячії ІНЛ у кардіоревматологічних пацієнтів з ознаками перенесеного холециститу, холелітіазом та холецистектомією в анамнезі

\begin{tabular}{|c|c|c|}
\hline Нозологія & \begin{tabular}{|r} 
Складові зв'язку \\
\end{tabular} & $\mathbf{R}$ \\
\hline \multicolumn{3}{|c|}{ Ознаки перенесеного холециститу } \\
\hline \multirow[t]{4}{*}{ IXC, HC } & ІНЛ-серомукоїди & 0,57 \\
\hline & НЛ-загальний фібриноген (p=0,01) & 0,63 \\
\hline & ІНЛ-міжшлуночкова перетинка & 0,51 \\
\hline & ІНЛ- задня стінка лівого шлуночка & 0,45 \\
\hline Стабільні форми IXC & ІНЛ- ліве передсердя, розмір & 0,91 \\
\hline \multirow[t]{5}{*}{ Геморагічний васкуліт } & ІНЛ-правий шлуночок, розмір & 0,66 \\
\hline & ІНЛ- ліве передсердя, розмір & 0,65 \\
\hline & ІНЛ-еритроцити & 0,83 \\
\hline & ІНЛ-гемоглобін & 0,62 \\
\hline & ІНЛ-лейкоцити крові & 0,65 \\
\hline \multirow[t]{6}{*}{ Ревматична гарячка } & ІНЛ-лівий шлуночок, діастола & $-0,82$ \\
\hline & IНЛ-ЧСС $(* p=0,06)$ & $0,82^{*}$ \\
\hline & ІНЛ-АСТ & 0,83 \\
\hline & ІНЛ-індекс до Рітіса & 0,88 \\
\hline & ІНЛ- загальний фібриноген & 0,82 \\
\hline & ІНЛ-глюкоза крові натще & $-0,94$ \\
\hline \multicolumn{3}{|c|}{$\begin{array}{c}\text { Холелітіаз } \\
\end{array}$} \\
\hline $\mathrm{IXC}, \mathrm{IM}$ & ІІНЛ- глюкоза натще & $-0,37$ \\
\hline $\mathrm{IXC}, \mathrm{HC}$ & ІНЛ-серомукоїди & 0,64 \\
\hline \multirow[t]{5}{*}{ Стабільні форми IXC } & ІНЛ-лейкоцити & 0,51 \\
\hline & ІНЛ-креатинін & 0,81 \\
\hline & ІНЛ-ШОЕ & 0,64 \\
\hline & ІІНЛ-сечовина & 0,92 \\
\hline & ІНЛ-глюкоза крові натще & 0,59 \\
\hline \multirow[t]{2}{*}{ XPXC } & ІНЛ-вік пацієнтів & 0,94 \\
\hline & ІНЛ-сечовина & 0,98 \\
\hline \multicolumn{3}{|c|}{ XE в анамнезі } \\
\hline \multirow[t]{2}{*}{ Стабільні форми IXC } & ІНЛ-протромбіновий час & 0,88 \\
\hline & ІНЛ- протромбіновий індекс & $-0,84$ \\
\hline Геморагічний васкуліт & ІНЛ-задня стінка лівого шлуночка & 0,96 \\
\hline
\end{tabular}

Примітка: ЧСС - частота серцевих скорочень

За умов холелітіазу кореляції 3 гострофазовими показниками запалення були представлені лейкоцитами крові (IXC, CC), серомукоїдами (IXC, HC), ШОЕ (IXC, CC). Крім того, були зафіксовані зв'язки з глюкозою крові натще (IXC, IM; IXC, CC) та сечовиною (IXC, CC; XPXC) (табл. 3). Найменша кількість кореляцій була встановлена серед осіб з ХЕ в анамнезі, що може бути зумовлено тим, що у цій групі було менше пацієнтів, адже серед хворих на ревматичну гарячку та ХРХC таких осіб взагалі не було. У пацієнтів, у яких ЖМ було видалено 3 приводу холелітіазу, ІНЛ корелював 3 протромбіновим часом та протроміновим індексом (IXC, CC) і товщиною задньої стінки ЛШ (ГВ) (табл. 4).

У жодній групі чи підгрупі індекс ІНЛ не корелював із тривалістю стаціонарного лікування, рівнямем артеріального тиску, наявністю аритмії, білірубіном та маркерами холестазу, амілазою/діастазою, загальним холестерином та тригліцеридами, загальним білком, швидкістю клубочкової фільтрації, а серед параметрів ехокардіограми - 3 часом прискорення ( $\left.\mathrm{T}_{\mathrm{acc}}\right)$, тиском у легеневій артерії.

Загалом, ІНЛ зростав 3 віком пацієнтів та асоціювався 3 гострофазовими показниками запалення (найчастіше - 3 загальним фібриногеном, серомукоїдами, лейкоцитами та 
ШОЕ), що підтверджує дані літератури [12]. Вперше встановлено, що ІНЛ пов'язаний також 3 вуглеводним метаболізмом та ендогенною інтоксикацією, що відкриває перспективи дослідження його визначення у пацієнтів 3 цукровим діабетом. Найбільш цікавими вбачаються виявлені асоціації ІНЛ 3 структурно-функціональним станом серця (розтіри камер, товщини стінок та фракція викиду), що може вказувати на те, що саме дисбаланс між активацією та обмеженням запалення призводить до структурнофункціональних змін серця 3 клінічно значущими гемодинамічними наслідками. Такі зміни можуть бути підтверджені кореляціями ІНЛ $з$ кардіоспецифічною трансаміназою АCT та індексом де Рітіса. Тобто, активація запалення викликає пошкодження міокарда 3 вивільненням АСТ з кардіоміоцитів, що, своєю чергою, проявляється збільшенням індексу де Pitica.

\section{Висновки}

1. ІНЛ був вищим за умов активного запального процесу при геморагічному васкуліті $(3,66)$ та ревматичній гарячці $(3,24)$, ніж при стабільних формах IXC $(2,47)$ та інфаркті міокарда $(1,85)$, усі $\mathrm{p}<0,05$.

2. Незважаючи на нозологію, значення IНЛ залежало від стану ЖМ і максимальним завжди було за умов змін його змін.

3. Кореляції ІНЛ залежали від стану ЖМ і були найчисленнішими за умов інтактного ЖМ; ІНЛ асоціювався 3 віком та частотою серцевих скорочень, гострофазовими показниками запалення, ендогенної інтоксикації, цитолізу та структурними характеристиками серця (розміри камер, товщини стінок, фракція викиду), що дає можливість використовувати його для діагностики вісцеро-вісцеральної кардіонейропатії.

Головними обмеженнями дослідження є його ретроспективний характер та незначна кількість пацієнтів у деяких групах. Конфлікт інтересів відсутній. Жодне фінансування не проводилось; запозичення ідей відсутне.

\section{Список літератури}

1. Ozyilmaz S, Akgul O, Uyarel H. et al. The importance of the neutrophil-to-lymphocyte ratio in patients with hypertrophic cardiomyopathy. [Article in English, Portuguese]. Rev Port Cardiol. 2017;36(4):239-246. doi: 10.1016/j.repc.2016.09.014.
2. Delcea C, Buzea CA, Dan GA. The neutrophil to lymphocyte ratio in heart failure: a comprehensive review. Rom J Intern Med. 2019;57(4):296-314. doi: 10.2478/rjim-2019-0018. 3. Філіпюк АЛ, Радченко ОМ. Виживаність пацієнтів 3 хронічною ішемічною хворобою серця залежно від типу адаптаційної реакції. Кровообіг та гемостаз.2011; 1-2:96-100. 4. Balta S, Celik T, Mikhailidis DP et al. The Relation Between Atherosclerosis and the Neutrophil-Lymphocyte Ratio. Clin Appl Thromb Hemost. 2016;22(5):405-411. doi: 10.1177/1076029615569568.

5. Стрільчук ЛМ. Розрахункові параметри ліпідограми: сучасні погляди та кореляції з лабораторноінструментальними показниками. Acta Medica Leopoliensia. 2017;XXIII(3):72-78.

6. Droste C. [Pain perception and peripheral pain localization in angina pectoris]. Zeitschrift Für Kardiologie. 1988;77:15-33.

7. Beliaev AM, Angelo N, Booth M, Bergin C. Evaluation of neutrophil-to-lymphocyte ratio as a potential biomarker for acute cholecystitis. J Surg.Res. 2017;209:93-101. doi: 10.1016/j.jss.2016.09.034.

8. Micić D, Stanković S, Lalić N, Đukić V, Polovina S. Prognostic Value of Preoperative Neutrophil-to-lymphocyte Ratio for Prediction of Severe Cholecystitis. J Med Biochem. 2018;37(2):121-127. doi: 10.1515/jomb-2017-0063.

9. Радченко ОМ, Пилипів ЛI. Гематологічні параметри у хворих на хронічне обструктивне захворювання легень 3 дистресом та еустресом. Актуальні проблеми сучасної медицини. 2016;16(4):175-179.

10. Forget P, Khalifa C, Defour J-Ph et al. What is the normal value of the neutrophil-to-lymphocyte ratio? BMCRes Notes. 2017;10:12. doi: 10. 1186/s13104-016-2335.

11. Стрільчук ЛМ. Механізми холецисто-кардіальних взаємодій (огляд літератури та власні дослідження). Експериментальна та клінічна медицина. 2018;2-3:79-87.

12. Günay E, Sarınç Ulaşlı S, Akar O et al. Neutrophil-tolymphocyte ratio in chronic obstructive pulmonary disease: a retrospective study. Inflammation. 2014; 37: 374-380.

\section{References}

1. Ozyilmaz S, Akgul O, Uyarel H. et al. The importance of the neutrophil-to-lymphocyte ratio in patients with hypertrophic cardiomyopathy. [Article in English, Portuguese]. Rev Port Cardiol. 2017;36(4):239-246. doi: 10.1016/j.repc.2016.09.014

2. Delcea C, Buzea CA, Dan GA. The neutrophil to lymphocyte ratio in heart failure: a comprehensive review. Rom J Intern Med. 2019;57(4):296-314. doi: 10.2478/rjim-2019-0018. 3. Filipyuk AL, Radchenko OM. Vyzhyvanist' patsientiv z khronichnoyu ishemichnoyu khvoroboyu sercya zalezhno vid typu adaptatsijnoji reaktsiji. [Article in Ukrainian]. Krovoobih ta hemostaz. 2011; 1-2:96-100.

4. Balta S, Celik T, Mikhailidis DP et al. The Relation Between Atherosclerosis and the Neutrophil-Lymphocyte Ratio. Clin Appl Thromb Hemost. 2016;22(5):405-411. doi: 10.1177/1076029615569568.

5. Strilchuk LM. Rozrakunkovi parametry lipidohramy: suchasni pohlyady ta korelyatsiji z laboratornoinstrumental'nymy pokaznykamy. [Article in Ukrainian]. Acta Medica Leopoliensia. 2017;XXIII(3):72-78.

6. Droste C. [Pain perception and peripheral pain localization in angina pectoris]. Zeitschrift Für Kardiologie. 1988;77:15-33. 
7. Beliaev AM, Angelo N, Booth M, Bergin C. Evaluation of neutrophil-to-lymphocyte ratio as a potential biomarker for acute cholecystitis. J Surg.Res. 2017;209:93-101. doi: 10.1016/j.jss.2016.09.034.

8. Micić D, Stanković S, Lalić N, Đukić V, Polovina S. Prognostic Value of Preoperative Neutrophil-to-lymphocyte Ratio for Prediction of Severe Cholecystitis. J Med Biochem. 2018;37(2):121-127. doi: 10.1515/jomb-2017-0063.

9. Radchenko OM, Pylypiv LI. Hematolohichni parametry u khvorykh na khrnichni obstruktyvni zakhvoryuvannya lehen ' $\mathrm{z}$ dystresom ta eustresom. [Article in
Ukrainian]. Aktual'ni problemy suchasnoji medytsyny. 2016;16(4):175-179.

10. Forget $\mathrm{P}$, Khalifa $\mathrm{C}$, Defour $\mathrm{J}-\mathrm{Ph}$ et al. What is the normal value of the neutrophil-to-lymphocyte ratio? BMCRes Notes. 2017;10:12. doi: 10. 1186/s13104-016-2335.

11. Strilchuk LM. Mekhanizmy kholetsysto-kardial’nykh vzaemodij (jhlyad literatury ta vlasni doslidzhennya). [Article in Ukrainian]. Eksperymental'na ta klinichna medycyna. 2018;23:79-87.

12. Günay E, Sarınç Ulaşlı S, Akar O et al. Neutrophil-tolymphocyte ratio in chronic obstructive pulmonary disease: a retrospective study. Inflammation. 2014; 37: 374-380.

\title{
NEUTROPHIL TO LYMPHOCYTE RATIO IN THE DIAGNOSIS OF VISCERO-VISCERAL CARDIONEUROPATHY IN PATIENTS WITH GALLBLADDER DISORDERS
}

\author{
Strilchuk Larysa
}

Mail for correspondence: larysa.stril4uk@ukr.net

Summary. Neutrophils to lymphocytes ratio (NLR) reflects the activity of systemic nonspecific inflammation and immune system answer. NLR can be influenced by the change of gallbladder condition. It's a pity, but the diagnostic and prognostic opportunities of NLR are not properly used in routine clinical practice. The aim of this paper was to estimate the NLR value in the assessment of heart condition in the diagnostics of viscero-visceral cardioneuropathy in dependence of gallbladder condition in patients with cardiorheumatic disorders. We analyzed data of 506 inpatients with cardiorheumatic diseases, which were divided into groups according to gallbladder condition: intact gallbladder; sludge, polips and cholesterosis; various deformations of gallbladder body; gallbladder neck deformations and sonographic signs of past cholecystitis; cholelithiasis; anamnesis of cholecystectomy. It was established that NLR levels, revealed in this study, exceeded the levels of healthy people according to our previous studies (1.8 \pm 0.46$)$ and literature data (1.65-1.86). NLR was dependent of gallbladder condition: maximal levels always accompanied pathological changes of the latter. On the background of active inflammatory phase of rheumatic diseases NLR was higher, than in case of stable and acute forms of ischemic heart disease. NLR correlations depended on gallbladder condition, and were the most numerous in case of intact gallbladder. NLR was associated with age, heart rate, acute phase inflammatory markers, parameters of endogenous intoxication, cytolysis and structural heart parameters (sizes of chambers, thicknesses of walls, ejection fraction). Ranking analysis of NLR of all included patients showed that its levels were maximal in case of cholecystitis in anamnesis and in patients after cholecystectomy. All other values can be clearly divided into 2 groups: intact gallbladder plus bent gallbladder body and, apart of it, other pathological conditions (sludge, signs of cholecystitis in anamnesis, cholelithiasis and cholecystectomy in anamnesis). Conclusions: NLR was the highest in case of active inflammatory process in hemorrhagic vasculitis (3.66) and rheumatic fever (3.24) than in the stable ischemic heart disease (2.47) and myocardial infarction (1.85), all $p<0.05$. Regardless of the disorder, NLR was dependent on the gallbladder condition and reached the maximal values in case of gallbladder changes. Taking into account the big amount of NLR correlations with clinical and laboratory parameters, and the results of instrumental diagnostics methods, we can say that NLR may be used in the diagnostics of viscerovisceral cardioneuropathy.

Key words: neutrophil to lymphocyte ratio, ischemic heart disease, gallbladder condition, viscero-visceral cardioneuropathy

Information about author

Strilchuk Larysa, Ph.D., Assoc.

Prof., Department of Therapy \#1, Medical Diagnostic, Haematology and
Transfusiology, Lviv National Medical University named after Danylo Halytsky, Pekarska Str, 69, Lviv, Ukraine, 79010 e-mail: larysa.stril4uk@ukr.net, https://orcid.org/0000-0001-7077-2610 


\title{
ОТНОШЕНИЕ НЕЙТРОФИЛОВ К ЛИМФОЦИТАМ В ДИАГНОСТИКЕ ВИСЦЕРО-ВИСЦЕРАЛЬНОЙ КАРДИОНЕЙРОПАТИИ У ПАЦИЕНТОВ С ПОРАЖЕНИЯМИ ЖЕЛЧНОГО ПУЗЫРЯ
}

\author{
Стрильчук Л. Н.
}

Почта для переписки: larysa.stril4uk@ukr.net

Резюме. Отнотение нейтрофилов к лимфочитам, или индекс «нейтрофильллимфоииты» (ИНЛ) отображает активность системного неспецифического воспаления и ответа иммунной системы. На ИНЛ может влиять изменение состояния желчного пузыря. С целью оценки возможности применения ИНЛ для определения состояния сердиа в диагностике висиеро-висиеральной кардионейропатии зависимо от состояния желчного пузыря у паџиентов с кардиоревматологическими патологическими состояниями проанализированы результать обследования 506 стационарных пациентов $c$ кардиоревматологическими болезнями, которых зависимо от состояния желчного пузыря разделили на группы: интактный желчный пузырь; сладж, полипы и холестероз; перегибы и деформации тела желчного пузыря; деформации шейки и сонографические признаки перенесенного холецистита; холелитиаз; холецистэктомия в анамнезе. Установлено, что полученные в данном исследовании уровни превыпают значения для здоровых лии в наших предыдущих исследованиях $(1,8 \pm 0,46)$ и данные литературы $(1,65-1,86)$. ИНЛ зависел от состояния желчного пузыря: максимальные значения всегда сопровождали патологические изменения последнего. В условиях активной воспалительной фазы ревматологических болезней ИНЛ был более высоким, чем при стабильных и острых формах ишемической болезни сердиа. Корреляции ИНЛ зависели от состояния желчного пузыря, были наиболее многочисленными при интактном желчном пузыре; ИНЛ ассоииировался с возрастом и частотой сердечных сокращений, острофазовыми показателями воспаления, параметрами эндогенной интоксикации, цитолиза и структурными характеристиками сердиа (размер камер, толщина стенок, фракция выброса). Выводы: ИНЛ был более высоким в условиях активного воспалительного процесса при геморрагическом васкулите $(3,66)$ и ревматической лихорадке $(3,24)$, чем при стабильных формах ишемической болезни сердия $(2,47)$ и инфаркте миокарда $(1,85)$, все $p<0,05$. Независимо от нозологии значение ИНЛ зависело от состояния желчного пузыря и максимальным всегда являлось при его изменениях. Учитывая большое количество корреляиий с клиническими и лабораторными показателями, а также результатами инструментальных обследований, ИНЛ может применяться в диагностике висиеро-висиеральной кардионейропатии.

Ключевые слова: отношение нейтрофилов к лимфоцитам, ишемическая болезнь сердца, состояние желчного пузыря, висцеро-висцеральная кардионейропатия

\section{Информация об авторах}

Стрильчук Лариса Николаевна., национального медицинского

к. мед. н., доцент кафедры терапии №1, университета им. Данилы Галицкого, ул. медицинской диагностики и гематологии Пекарская, 69, Львов, Украина, 79010

e-mail: larysa.stril4uk@ukr.net https://orcid.org/0000-0001-7077-2610

Conflicts of interest: author has no conflict of interest to declare.

Конфлікт інтересів: відсутній.

Конфликт интересов: отсутствует. 


\title{
СИСТЕМАТИЗАЦІЯ ЗАХОДІВ ФІЗИЧНОЇ РЕАБІЛІТАЦІї ДІТЕЙ ЗІ СПАДКОВИМИ НЕРВОВО-М'ЯЗОВИМИ ЗАХВОРЮВАННЯМИ
}

\author{
Чернишова І. М., Луценко О. В., Данильчук А. В., Логвін Г. Б.
}

Пошта для листування: iraortoped@gmail.com

\begin{abstract}
Резюме. Діти зі спадковими нервово-м'язовими захворюваннями складають одну з основних груп пацієнтів в державних $i$ приватних реабілітаційних центрах. Проведення курсу реабілітачії потребує розробки індивідуальної реабілітаиійної програми, вимагає раціонального вибору засобів фізичної реабілітації, їх систематизаиії в залежності від рівня функиіональних можливостей дитини. Мета. Формування комплексного підходу при рачіональному виборі методів фізичної реабілітації та ортопедичного постачання дітей зі спадковими нервово-м'язовими захворюваннями. Завдання. Розробка етапів надання реабілітаційних послуг, алгоритму вибору методик фізичної реабілітації та технічних засобів в залежності від ступеня обмеження рухових можливостей дитини. Результати. У дослідженні брали участь 46 дітей у віці від 2 до 15 років. Курс реабілітаиії, згідно з алгоритмом, складався з 4 етапів: етапу діагностики, етапу формування індивідуальної програми реабілітації відповідно до функиіональними можливостями пацієнта, етапу проведення курсу фізичної реабілітації та етапу оцінки його ефективності. Основні принципи реабілітації: розтягнення контраговаиіх тканин, позиціонування сегментів кінцівок та хребта, фізична активність в субмаксимальному режимі, вертикалізація, профілактика деформаџій за допомогою ортезів. Проведений курс сприяв стабілізації м'язової сили і рухової активності, підвищення обсягу пасивних рухів у великих суглобах, розвитку спритності дрібної моторики. Технічні засоби реабілітації сприяли усуненню патологічної установки кінцівок і хребта. Висновки. Адекватні реабілітаційні заходи, спрямовані на збереження рухової активності пацієнтів, підтримку тонусу м'язів (в тому числі і дихальної мускулатури), своєчасну корекиію патологічних установок кінцівок $і$ хребта у дітей з прогресуючими нервово-м'язовими захворюваннями, гальмують розвиток деформацій, пролонгують рухову активність.
\end{abstract}

Ключові слова: спадкові нервово-м’язові захворювання, фізична реабілітація, ортезування

Інформація про авторів

Чернишова Ірина, к. мед. н., зав. відділенням комплексної діагностики та реабілітації Українського інституту протезування, протезобудування та відновлення працездатності, вул. Клочківська,339, Харків, Україна, 61061 e-mail: iraortoped@gmail.com,

https://orcid.org/0000-0002-2903-3880

Луценко Олена, к. мед. н., доцент, наук. співроб. відділення комплексної

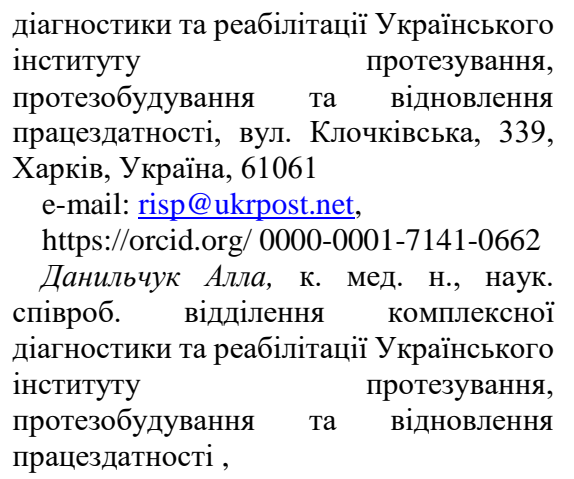

діагностики та реабілітації Українського

вул. Клочківська, 339, Харків, Україна, 61061

e-mail: risp@ukrpost.net

Логвін Галіна, лікар-невролог дитячий сектору відновлювального лікування пацієнтів з патологією опорно-рухового апарату Українського інституту протезування, протезобудування та відновлення працездатності, вул. Клочківська, 339, Харків, Україна, 61061 e-mail: risp@ukrpost.net

\section{Вступ}

За даними меморандуму ВООЗ спадкові нервово-м'язові захворювання відносяться до найбільш невивчених захворювань людства 3 частотою випадків 1 на $5-10$ тис. осіб та включають більше 300 форм. Неврологічний дефіцит та ортопедичні ускладнення (контрактури, деформації кінцівок та хребта), які $\epsilon$ обов'язковими супутниками та наслідками міодистрофічного процесу, присутні при всіх випадках нервово-м'язової патології та призводять до втрати пацієнтом функції опори, ходьби та самообслуговування. У 2017 році Міжнародна конференція зі стандарту лікуванняспинаоьної м'язової атрофії (CMA) та робоча група по лікуванню м'язової дистрофії внесли оновлення консенсусного висновку щодо вживання активніших заходів у лікуванні цих захворювань. Діти 3 цією патологією, поряд 3 дітьми 3 церебральним паралічем, складають основну групу пацієнтів державних та приватних реабілітаційних закладів. Тому виникає необхідність в раціональному виборі засобів фізичної реабілітації, їх систематизації в залежності від рівня функціональних можливостей дитини, ступеню втрати фізичних можливостей, що $є$ актуальним при розробці індивідуальної програми реабілітації в центрах [1 - 5]. Метою нашої роботи було формування комплексного підходу до раціонального вибору

(C) Чернишова I. М., Луценко О. В., Данильчук А. В., Логвін Г. Б., АРРМ, 2020 
засобів фізичної реабілітації та ортопедичного забезпечення пацієнтів зі спадковими нервовом'язовими захворюваннями.

\section{Матеріали та методи дослідження}

За даним алгоритмом курс реабілітації в 2018 2019 роках пройшли 46 дітей віком від 2 до 15 років, 28 дівчаток та 18 хлопчиків. 3 них дітей зі спинальною м'язовою атрофією (СМА) було 25 осіб, 3 прогресуючою м'язовою дистрофією (ПМА) - 16 дітей та 3 міопатичним синдромом - 5 пацієнтів.

Оцінку функціонального стану дітей, відповідно до рекомендацій Міжнародного комітету зі стандартів лікування хворих з СМА, проводили за шкалою Хаммерсміта [1, 3, 4], оцінку сили м'язів - за тестом Lovett (Робенеску М., 1972; Белова А. Н., 2002). В ході обстеження за функціональним станом виділені 3 групи хворих:

1 група - «лежачі» пацієнти, які не можуть самостійно сидіти (шкала Хамерсміта 20 - 40 балів, тест Lovett 3 - 5 балів);

2 група - «сидячі» пацієнти, які можуть самостійно сидіти, але не можуть самостійно ходити (шкала Хаммерсміта 10 - 20 балів, тест Lovett 2 - 3 бали);

3 група - «ходячі» пацієнти, які можуть ходити самостійно (шкала Хаммерсміта 0 - 10 балів, тест Lovett 0 - 1 бал).

Програма реабілітації пацієнтів тривалістю 15 днів включала 4 етапи: етап діагностики (тестування, рентгенографія, електроміографія); етап складання індивідуальної програми реабілітації згідно функціональним можливостям пацієнта; етап проведення курсу фізичної реабілітації згідно програми, та етап оцінки проведених заходів (повторне тестування).

Індивідуальна програма реабілітації розроблялася мультидисциплінарною командою в складі: ортопеда, невролога, фізичного реабілітолога, ерготерапевта, психолога та ортезиста. Заходи курсу фізичної реабілітації були спрямовані на поліпшення трофіки, мікроциркуляції тканин, підвищення щільності кісток, усунення болю при рухах в суглобах, розробку контрактур, а також - на покращення дрібної моторики (спритність рухів).

Основними принципами проведення реабілітаційних заходів для пацієнтів 3 даною патологією, згідно Міжнародному стандарту [1,
4], було: розтягнення контрагованих тканин, позиціонування сегментів кінцівок та хребта, фізична активність в субмаксимальному навантаженні, вертикалізація в положенні «сидячи», «стоячи» з використанням допоміжних засобів реабілітації, компенсації втрачених функцій та ортопедична корекція за допомогою ортезів різної конструкції.

Із заходів апаратної фізіотерапії призначалися: парафіно-озокеритові аплікації 29 - 33 градусів по 10 - 15 хвилин щодня або через день, бальнеолікування (ванни) 35 - 36 градусів по 8 10 хвилин щодня або через день.

Кінезіотерапія проводилась в щадному режимі: лікувальна гімнастика для всіх груп м'язів в положенні «лежачи», «сидячи» або «стоячи», в залежності від здатності дитини утримувати вертикальне положення; легкий масаж 15 - 20 хвилин; роботизована механотерапія 3 рухами у щадному режимі (середня швидкість, розвантаження при осьовому навантаженні) не більш 15 хвилин, курсом 10 процедур; гімнастика в теплому басейні $15-20$ хвилин, через день; ходьба в пневмокостюмі «Атлант» через день.

В кінці курсу реабілітації проводилося раціональне ортезування в залежності від функціонального стану пацієнта. Особливостями ортезування $є$ використання легких матеріалів та мінімальне обмеження рухів кінцівок. Діти, які не можуть утримувати положення «сидячи», забезпечувались ортезом для сидіння (індивідуальним кріслом) для позиціонування тулуба, при прогресуванні деформації хребта виготовлявався жорсткий корсет. Діти, які не можуть самостійне стояти i рухати ногами, забезпечувались ортезом 3 реципрокним механізмом для пересування 3 підтримкою або самостійно. Дітей, які пересувались на обмежену відстань через слабкість м'язів, забезпечували полегшеними шарнірними ортезами на ноги або стопу, та ортопедичним взуття.

3 метою систематизації реабілітаційних заходів, конкретизації технічних засобів реабілітації (ТЗР) та методик фізичної реабілітації відповідно до функціональних можливостей пацієнтів, що необхідно при складанні індивідуальної програми реабілітації, розроблено алгоритм вибору методик фізичної реабілітації і ТЗР в залежності від ступеня обмеження рухових функцій (рис. 1). 
I етап

Діагностика визначення груп хворих

Diagnostics

Formation groups of patients

II етап Складання IIIP Rehabilitation program

\section{III етап \\ Проведення реабілітації Ортезування Rehabilitation Orthosis}

IV етап

Оцінка

Fssessment

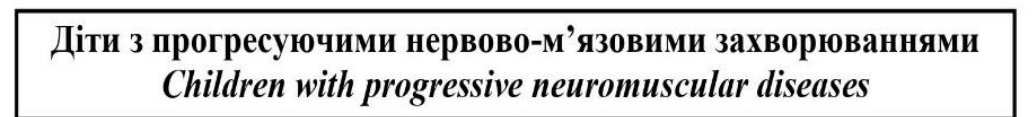
Children with progressive neuromuscular diseases

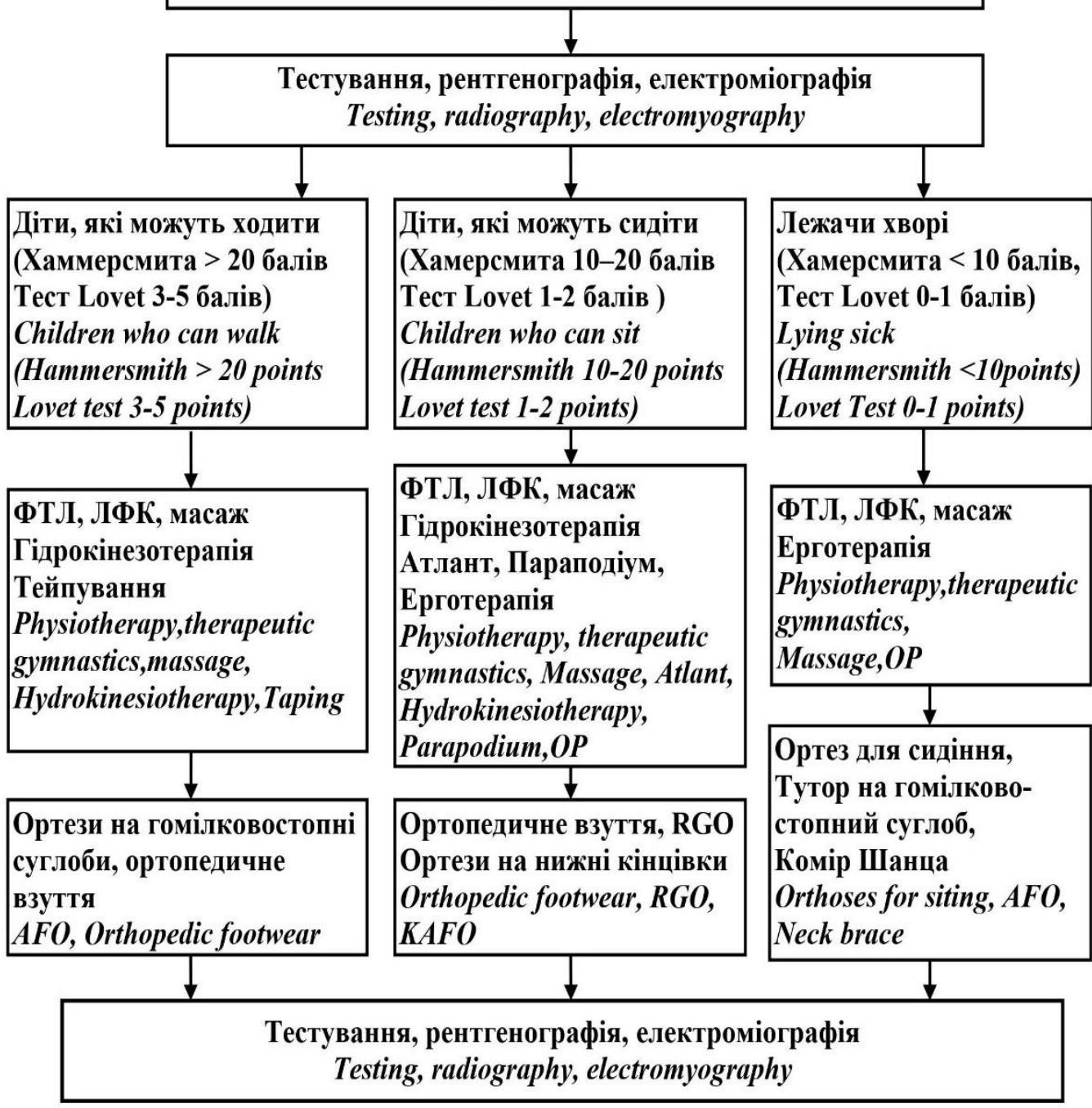

Рис. 1. Алгоритм вибору методик фізичної реабілітаиії і ТЗР в залежності від ступеня обмеження рухових функиій

\section{Результати і обговорення}

Згідно розробленому алгоритму, курс реабілітації дітей 1 групи (23 дитини) включав: лікувальну гімнастику в положенні «лежачи», масаж, фізіо-терапевтичне лікування (ФТЛ) та забезпечення ортезом для сидіння або корсетом. Дітям 2 групи (15 пацієнтів) проводили: лікувальну гімнастику в положенні «лежачи», «сидячи», масаж, ФТЛ, роботизовану механотерапію (Lokomat), гімнастику в басейні. 3 ортезного забезпечення - корсет, тутори на стопу, реципрокний ортез для ходьби. Для дітей 3 групи (8 пацієнтів) було передбачено: лікувальна гімнастика «стоячи», «сидячи», масаж, ФТЛ, роботизована механотерапія (Lokomat), гімнастика в басейні, ходьба в пневмокостюмі
«Атлант», забезпечувалися ортезами на стопу, ортопедичним взуттям.

Беручи до уваги прогресуючий характер спадкових нервово-м'язових захворювань, супутню патологію 3 боку опорно-рухового апарату, серцево-судинної та дихальної систем, позитивний результат дворічного (2 3 курсів реабілітації) спостереження пацієнтів можна говорити про ефективність такого комплексного підходу для збереження та навіть незначного покращення рухової активності пацієнта.

За результатами тестування (Lovett, Хаммерсміта,) спостерігалась стабілізація м'язової сили та рухової активності у великих суглобах без негативної динаміки функціонального статусу протягом часу спостереження, пацієнти перебували в тих же 
функціональних групах. Курс реабілітації тривалістю 15 днів дозволяв збільшити показники рухової активності в межах 2 - 5 балів за тестом Хамерсмита у всіх дітей. При тугорухливісті колінних та кульшових суглобів після регулярного використання засобів роботизованої кінезіотерапії та ортезних систем збільшився обсяг пасивних рухів у великих суглобах нижніх кінцівок на 10 - 15 градусів. Отримані технічні засоби реабілітації дозволили провести корекцію деформації сегментів кінцівок, хребта, патологічної постави та пози, що сприяло профілактиці їх прогресування. Методики ерготерапії в ігровій формі дозволили підвищити спритність рухів при виконанні завдань на дрібну моторику, що підвищувало мотивацію дитини. Діти соціалізовані, активні, iз задоволенням брали участь в заняттях 3 реабілітологом.

\section{Висновки}

Практика показала, що адекватні реабілітаційні заходи, спрямовані на збереження рухової активності пацієнтів, підтримку тонусу м'язів (в тому числі і дихальної мускулатури), своєчасну корекцію контрактур та патологічних установок кінцівок та хребта у дітей $з$ прогресуючими нейром'язовими захворюваннями, гальмують розвиток деформацій, пролонгують незалежність пересування та самообслуговування. Це відображується на тривалості життя дитини та $є$ перспективним напрямком подальших досліджень. Системний підхід до вибору методів фізичної реабілітації та ортопедичного постачання дозволить допомогти співробітникам реабілітаційних центрів в складанні індивідуальної, пацієнторієнтованої програми реабілітації для цієї важкої групи хворих.

\section{Список літератури}

1. Richard S. Finkel, et al., Diagnosis and management of spinal muscular atrophy: Part 1: Recommendation for diagnosis, rehabilitation, orthopedic and nutritional care; Part 2: Pulmonary and acute care; medications, supplement and immunizations; other organ systems; and ethics, Neuromuscular disorders (2017), doi: 10.1016/j.nmd. 2017.11.004
2. David J Birnkrant, Katharine Bushby, Carla M Bann, Benjamin A Alman, Susan D Apkon, Angela Blackwell, Laura E Case, Linda Cripe, Stasia Hadjiyannakis, Aaron K Olson, Daniel W Sheehan, Julie Bolen, David R Weber, Leanne M Ward, for the DMD Care Considerations Working Group Diagnosis and management of Duchenne muscular dystrophy, part 2: respiratory, cardiac, bone health, and orthopaedic management, p. 6 - 15 електроний ресурс : www.thelancet.com/neurology Published online January 23, 2018 http://dx.dol.org/10.1016/S1474-4422(18)30025-5

3. Інформаційний лист МО3 України від 14.09.2010 «Рєєстрація та медичне обслуговування дітей 3 нервовом'язовими захворюваннями (Спінальна атрофія, м'язова дистрофія Дюшена)»

4. Ching H. Wang, Richard S.Finkel, Enrico S.Bertini, Mary Schroth, Anita Simonds, Brenda Wong, Annie Aloysius, Lesli Morrison, Marion Main, Thomas O.Crawford, Anthony Trela and Partieipans of the International Conference on SMA Standard of Care. Consensus statement for standard of care in spinal muscular atrophy // Journal of Child Neurology. -2007. -vol. 22. -P. 1027-1049.

5. Комплексное санаторно-курортное лечение наследственных нервно-мышечных заболеваний, Методическое пособие для врачей. - Ненько А.М., Сиротюк М.В., - Евпатория, 2004. - 55 c.

\section{References}

1. Mercuri E, Finkel RS, Mountoni F, Wirth B, Main M, Mazzone ES, et al. Richard S. Finkel, Vinale M. et al. Diagnosis and management of spinal muscular atrophy: Part 1: Recommendation for diagnosis, rehabilitation, orthopedic and nutritional care; Part 2: Pulmonary and acute care; medications, supplement and immunizations; other organ systems; and ethics, j. nmd.2017; DOI: 10.1016/11(4): 5 14. https://pubmed.ncbi.nlm.nih.gov/29290580/

2 Birnkrant DJ, Bushby K, Bann CM, Alman BA, Apkon SD, Blackwell AF, et al. for the DMD Care Considerations Working Group Diagnosis and management of Duchenne muscular dystrophy, part 2: respiratory, cardiac, bone health, and orthopaedic management Lancet Neurol .2018):6 - 15. http://dx.dol.org/10.1016/S1474$4422(18) 30025-5$

3. Informatsiinyi lyst MOZ Ukrainy vid 14.09.2010 «Rieiestratsiia ta medychne obsluhovuvannia ditei $\mathrm{z}$ nervovo-miazovymy zakhvoriuvanniamy (Spinalna atrofiia, miazova dystrofiia Diushena)»

4. Wang CH, Finkel RS, Bertini ES, Schroth M, Simonds A, Wong B et al. and partieipans of the International Conference on SMA. Standard of Care. Consensus statement for standard of care in spinal muscular atrophy. J of Child Neurol. 2007; (22):1027-1049.

5. Nenko A.M., Syrotiuk M.V. (2004), «Kompleksnoe sanatorno-kurortnoe lechenye nasledstvennыkh nervnomыshechnыkh zabolevanyi», Metodycheskoe posobye dlia vrachei. Evpatoryia, $-55 \mathrm{~s}$. 


\title{
SYSTEMATIZATION OF METHODS OF PHYSICAL REHABILITATION OF CHILDREN WITH INHERITED NERVO-MUSCLE DISEASES
}

\author{
Chernyshova Iryna, Lutsenko Olena, Danylchuk Alla, Logvin Galina
}

Mail for correspondence: iraortoped@gmail.com

Summary. Children with hereditary neuromuscular diseases constitute one of the main groups of patients in public and private rehabilitation institutions. Therefore, there is a need to develop a rational choice of physical rehabilitation means, their systematization depending on the level of functional capabilities, which is relevant when developing an individual rehabilitation program in the centres. Purpose. Formation of an integrated approach in the rational choice of methods of physical rehabilitation and orthopedic supply for patients with hereditary neuromuscular diseases. Tasks. Development of stages for the provision of rehabilitation services, determination of the composition of an individual rehabilitation program, development of an algorithm for choosing methods of physical rehabilitation and technical means, depending on the degree of limitation of the child's motor functions. Results. The study involved 46 children aged 2 to 15 years. Assessment of the functional status of children, in accordance with the recommendations of the International Committee for the Standards of Treatment of patients with SMA, was performed on the Hammersmith scale, the assessment of muscle strength on the Lovett test. The rehabilitation course according to the developed algorithm consisted of 4 stages: the stage of diagnosis, the stage of drawing up an individual rehabilitation program in accordance with the patient's functional capabilities, the stage of the course of physical rehabilitation and the stage of assessing its effectiveness. The main principles of rehabilitation were: stretching of contracted tissues, positioning of segments of the limbs and spine, physical activity in a submaximal mode, verticalization with the use of aids, compensation of lost functions and orthopedic correction using orthoses of various designs. The course carried out helped to stabilize muscle strength and motor activity, increase the volume of passive movements in large joints, and fine motor dexterity. Technical means of rehabilitation made it possible to correct the deformity of the segments of the limbs and the spine, to increase the dexterity of movements when performing tasks for fine motor skills. Conclusions. Adequate rehabilitation measures aimed at maintaining the motor activity of patients, maintaining muscle tone (including the respiratory muscles), timely correction of pathological attitudes of the limbs and spine in children with progressive neuromuscular diseases, inhibit the development of deformities, prolong motor activity.

Key words: hereditary neuromuscular diseases, physical rehabilitation, orthoses

\section{Information about author}

Chernyshova Iryna, MD, PhD, Head of Rehabilitation Department, Ukrainian Institute of Prosthetics and Rehabilitation, Klochkovska street 339, Ukraine, 61061

e-mail: iraortoped@gmail.com,

https://orcid.org/ 0000-0002-2903-3880

Lutsenko Olena, MD, $\mathrm{PhD}$, Assoc. Prof., research staff of Rehabilitation Department,
Ukrainian Institute of Prosthetics and Rehabilitation, Klochkovskaya street, 339, Kharkov, Ukraine, 61061 e-mail: risp@ukrpost.net, https://orcid.org/ 0000-0001-7141-0662 Danylchuk Alla, research staff of Rehabilitation Department, Ukrainian Institute of Prosthetics and Rehabilitation,
Klochkovskaya street, 339, Kharkov, Ukraine, 61061

e-mail: risp@ukrpost.net

Logvin Galina, VD, pediatric neurologist of Rehabilitation Treatment sectors, Ukrainian Institute of Prosthetics and Rehabilitation, Klochkovskaya street, 339, Kharkov, Ukraine, 61061

e-mail: $\underline{\text { isp@ @ukrpost.net }}$

\section{СИСТЕМАТИЗАЦИЯ МЕТОДОВ ФІЗИЧЕСКОЙ РЕАБИЛИТАЦИИ ДЕТЕЙ С НАСЛЕДСТВЕННЫМИ НЕРВНО-МЫШЕЧНЫМИ ЗАБОЛЕВАНИЯМИ}

\author{
Чернышева И. Н., Луценко Е. В., Данильчук А. В., Логвин Г. Б.
}

Почта для переписки: iraortoped@gmail.com

\begin{abstract}
Резюме. Дети с наследственными нервно-мыпечными заболеваниями составляют одну из основных групп пациентов в государственных и частных реабилитационных иентрах. Проведение курса реабилитации требует разработки индивидуальной реабилитачионной программы с рациональным выбором средств физической реабилитации, их систематизачии в зависимости от уровня функииональных возможностей ребенка. Цель. Формирование комплексного подхода при рациональном выборе методов физической реабилитации и ортопедического снабжения детей с наследственными нервно-мылечныли заболеваниями. Задачи. Разработка этапов оказания реабилитачионных услуг, алгоритма выбора методик физической реабилитаџии и технических средств в зависимости от степени
\end{abstract}


ограничения двигательных возможностей ребенка. Результаты. В исследовании принимали участие 46 детей в возрасте от 2 до 15 лет. Курс реабилитации, согласно алгоритму, состоял из 4 этапов: этапа диагностики, этапа формирования индивидуальной программы реабилитации в соответствии $c$ функцииональныли возможностями пациента, этапа проведения курса физической реабилитации и этапа оценки его эффективности. Основные принципь реабилитации: растяжение контрагированных тканей, позиционирование сегментов конечностей и позвоночника, физическая активность в субмаксимальном режиме, вертикализаиия, профилактика деформаџий $c$ помощью ортезов. Проведенныии курс способствовал стабилизации мылечной силь и двигательной активности, повышению объема пассивных движений в крупных суставах, развитию ловкости мелкой моторики. Технические средства реабилитации способствовали устранению патологической установки конечностей и позвоночника. Выводы. Адекватные реабилитационные мероприятия, направленные на сохранение двигательной активности пачиентов, поддержание тонуса мыши (в том числе и дыхательной мускулатуры), своевременную коррекцию патологических установок конечностей $u$ позвоночника $y$ детей $c$ прогрессируюшими нейромышечными заболеваниями, задерживают развитие деформачий, пролонгируют двигательную активность.

Ключевые слова: наследственные нервно-мышечные заболевания, физическая реабилитация, ортезирования

\section{Информация об авторах}

Чернышева Ирина, к. мед. н., зав. отделением комплексной диагностики и реабилитации Украинского института протезирования, протезостроения и восстановления трудоспособности, ул. Клочковская, 339, Харьков, Украина, 61061

e-mail: iraortoped@gmail.com, https://orcid.org/ 0000-0002-2903-3880

Луценко Елена, к. мед. н., доц., научн. сотр. отделения комплексной диагностики и реабилитации, Украинского института протезирования, протезостроения и восстановления трудоспособности, ул. Клочковская, 339, Харьков, Украина, 61061 e-mail: risp@ukrpost.net,

https://orcid.org/0000-0001-7141-0662

Данильчук Алла, научн. сотр. отделения комплексной диагностики и реабилитации Украинского института протезирования, протезостроения и восстановления трудоспособности, ул. Клочковская, 339, Харьков, Украина, 61061

e-mail: risp@ukrpost.net
Логвин Галина, детский невролог сектора восстановительного лечения пациентов 3 патологией опорнодвигательного аппарата Украинского института протезирования, протезостроения и восстановления трудоспособности, ул. Клочковская, 339, Харьков, Украина, 61061 e-mail: risp@ukrpost.net

Conflicts of interest: author has no conflict of interest to declare.

Конфлікт інтересів: відсутній.

Конфликт интересов: отсутствует. 


\title{
INCONSTANT BONES OF THE HUMAN SKULLS FROM SCYTHIANS GRAVE FIELD NEAR KOLOMAK VILLAGE
}

\author{
Sherstyuk Sergey, Polstyanoi Andrii, Prokhorchuk Roksolana
}

Mail for correspondence: andreypolstyanoj@karazin.ua

\begin{abstract}
Summary: The research of the features of variant anatomy, as an integral part of paleoanthropological exploration, is an extremely important source of additional information about the anatomical structure of humans. Patterns of variability and frequency distribution of discrete variational features in variant anatomy remain important. Cranioscopic variational (or non-metric) features - anatomical variations in the skeleton structure, registered according to the "presence-absence" principle, are an important source of information in studying the origin and ethnogenetic relationships of paleopopulations. These features include inconstant (additional) skull bones. By modern classification, there are three types of inconstant bones of the human skull: wormian (sutural) bones, fontanelle bones and insular bones. They have various causes: genetic factors, chronic high intracranial pressure, skull deformation, disturbances of the skull symmetry, different pathological processes, etc. The purpose of the work was to research the variant anatomy of inconstant bones of the human skull. The objective to research is the variant anatomy of inconstant skull bones of the human on the anthropological materials from the Scythian grave field. It located near Kolomak village in the Kharkiv region and dates back to IX - IV century BC. The 88 skulls of adult persons has been researched. The inconstant additional bones of skull were present in the structures of 16 skulls out of $88(18.1 \%)$. Results. The sutural (wormian) bones were present in 12 skulls (13.6\%), fontanelle bones - in 6 skulls (6.8\%), insular bones were absent. In the anatomical structures of 10 skulls (11.4\%) were only wormian bones, in 4 skulls (4.5\%) were only fontanelle bones, in the structures of 2 skulls (2.3\%) were combination of sutural and fontanelle additional bones. Often the inconstant bones were located in several sutures at the same time. The most common sutural bones were lambdoid suture bones - 9 skulls (10.2\%). The inconstant bones of the coronal suture and sagittal suture were found in 2 skulls (2.3\%). The additional bones of the occipital-mastoid, parietal-mastoid and squamosal sutures were absent on the examined osteological materials. The fontanelle bones most often located at the place of the occipital fontanellele and they were present in 4 skulls (4.5\%). The additional fontanelle bones of the mastoid fontanellele were found in 2 skulls (2.3\%). The frontal fontanelle bone was in 1 skull (1.1\%). The additional fontanelle bones of the sphenoid fontanellele and interparietal bones were not found in the researched skulls. Conclusion. It is interesting to consider the case of combination in one skull a large inconstant bone of the sagittal suture with complete metopic (frontal) suture and occipital bone of sufficiently large size. The results of the research expanded and updated the existing data on the variant anatomy of inconstant cranial bones. Also, the results obtained maybe required in the further research of individual variability in the structure of the human's skull.
\end{abstract}

Key words: inconstant bones of the skull, wormian bones, sutural bones, fontanelle bones, human variant anatomy, paleoanthropology

\section{Information about author}

Sherstyuk Sergey, MD, PhD, Assoc.

Prof., The Head of the Department of

Human Anatomy of V. N. Karazin Kharkiv

National University, Svobody Sq, 6,

Kharkiv, Ukraine, 61022

e-mail: anatomy@karazin.ua

https://orcid.org/0000-0001-6062-7962
Polstyanoi Andrii, Assistant of Department of Human Anatomy of V. N. Karazin Kharkiv National University, Svobody Sq, 6, Kharkiv, Ukraine, 61022 e-mail: andreypolstyanoj@karazin.ua https://orcid.org/0000-0002-6513-1533
Prokhorchuk Roksolana, Assistant of Department of Human Anatomy of V. N. Karazin Kharkiv National University, Svobody Sq, 6, Kharkiv, Ukraine, 61022 e-mail: prokhorchuk@karazin.ua https://orcid.org/0000-0002-7194-5584
Introduction. In recent years, there have been some changes in trends in domestic and foreign anthropology. Currently, the importance of variant anatomy is increasing. However, the research of bone remains of modern and fossil human populations has always been of great importance for anthropological science, contributing to the research of its various directions. The research of the relationship between the 
variability of osteological features allows us to characterize the structural type of a group of individuals, as well as to compare intergroup and intragroup variability.

The research of the variant anatomy and features of individual anatomical formations, their topography from the standpoint of a macroscopic point of view is also considered relevant. The regularities of variability and frequency distribution of variational features in the context of variant anatomy remain are important. Therefore, the research of the features of variant anatomy, as an integral part of paleoanthropological research, is an extremely important source of additional information about the anatomical structure of humans [4].

In modern paleoanthropological research, variational features on skeletal bones play a significant role as an additional source of information. Variational features are nonmetric, qualitative features, which determined by the principle of "presence" or "absence". In anatomy in general, and in craniology in particular, this term has become widespread relatively recently recently in the last quarter of the twentieth century. Prior to that time, many variants of the anatomical structure in literary publications were usually called "anomalies".

Cranioscopic discrete variation, or nonmetric features, which are anatomical variations in the structure of the skull are an important source of information in studying the origin and ethnogenetic relationships of paleopopulations.

In modern historical and anthropological science the research of variational features on craniological material is widespread. Variational features on the skull are understood as variations in its anatomical structure, which are manifested in the form of inconstant bones [4].

One of these features is the inconstant bones of the skull, usually located between the normal permanent bones of the human skull $[5,9,11]$. According to the classification by Speransky V. and Zaichenko A. (1980) inconstant skull bones are divided into 3 groups: sutural or wormian (ossa suturalia), fontanelle (ossa fonticulorum), insular (ossa insularia). The names of the groups reflect their localization in the anatomical structure of the skull [11].

Wormian bones or sutural bones are accessory small bones which occur accidentally or intercalated between or near cranial sutures isolated from normal ossification center of skull [7].

The fontanelle bones located between the calvarial bones in the fontanelles and border on three or more permanent skull bones. These bones are derived from accessory ossification centers [8]. The fontanelle bones were first discovered in man in the sixteenth century by the physician Paracelsus, who gave them the name "ossiculum anti-epilepticum," believing them to be a remedy for epilepsy. Since that time various names have been given to this bone type by different researchers and authors: they have been often termed "os bregmaticum" and many other names. The insular bones are located inside the permanent bones of the skull [11].

Inconstant bones of the skull are develop in utero, and sometimes after birth. It is unclear at this time exactly how they are formed, although genetic as well as environmental factors have been proposed [1]. The appearance of these bones is due to a number of reasons: genetic factors, deformation and changes of symmetry in the anatomical structure of the skull, osteogenesis imperfecta, chronic increase in intracranial pressure, various pathological processes, can be combined with developmental abnormalities of the brain [9, 10, 11]. However, most often this phenomenon is associated with abnormalities in the manifestation of genetic differences at the phenotype level $[10,11]$.

At the same time, explorations by various authors show that the processes that lead to the appearance of inconstant bones, and the processes under the influence of which the skull is formed, are independent of each other [3]. The occurrence of fontanelles bone not connecting with the occurrence of wormian bones (except for weak connection anterior fontanelle bone and coronal suture bone), which may indicate the influence of various factors on their appearance [11]. Clinically 
inconstant bones are used as one of the markers in the diagnoses of many autosomal dominant genetic disorders, such as, craniosynostosis and osteogenesis imperfect [1].

According to the literature, additional bones of the human skull with various localization in different populations occur with a frequency of 20-67\% [2, 6, 7, 11]. Some authors note gender differences in the frequency of inconstant cranial bones, while other authors don't note such differences. Additional bones are most common in structure of the brachycranial skull type. At the same time, some authors, such as $\mathrm{H}$. Grimme, refute the relationship between the shape of the skull and the frequency with which additional bones occur [11].

The purpose of the work: exploration the variant anatomy of inconstant bones of the human skull on the anthropological materials from Scythians grave field near Kolomak village.

Materials and methods. This observational study was carried out on 88 adult skulls with different preservation (in most cases, only the neurocranium of them preserved, in some cases the skull base was damaged), which were extracted in the $\mathrm{XX}$ century from the grave field near Koloamak village and currently stored in osteological collection of the Department of Human Anatomy of the V. N. Karazin Kharkiv National University. The settlement and gravefield "Grashkivsky" of the IX century IV century BC near the village of Kolomak, Kharkiv region of Ukraine - archeological monument (Early Iron Age, Scythian culture). It located $0.5 \mathrm{~km}$. to the north-western part of the former Grishkovo village, which is currently the south-western outskirts of Kolomak village.
The basis of the research methodology is the identification and registration of variational features (presence of different types of additional skull bones) with subsequent statistical processing of the results to determine the frequency of these traits in the population.

All researches were performed in accordance with the Council of Europe Convention on the Protection of Human Rights and Human Dignity in the Application of Biology and Medicine: Convention on Human Rights and Biomedicine (ETS № 164) of 04.04.1997, and the Declaration of Helsinki World Medical Association (2008).

Results. In the our research the inconstant skull bones were present in the anatomical structure of 16 skulls out of 88 , which is $18.1 \%$ of the total.

The wormian (sutural) bones were present in structure of 12 skulls (13.6\%), fontanelle bones - in 6 skulls $(6.8 \%)$, insular bones were absent. Often inconstant bones in the skulls were located in several sutures at the same time.

The most common wormian inconstant bones were lambdoid suture bones. They were found in 9 skulls $(10.2 \%)$. In most cases, the lambdoid suture contained from 1 to 5 bones. Multiple lambdoid wormian bones have been found only in structure of the 1 skull $(1.1 \%)$, although statistics show that they are the most common variant of additional human skull bones in other populations.

The wormian bones of the lambdoid suture on the researched skulls were mostly partially elongated, crest-shaped, less often irregular or rounded. In the majority of cases, their size was $9-18 \mathrm{~mm}$, but smaller bones were also found. The location of these additional bones in 5 skulls $(5.7 \%)$ was bilateral, in 3 skulls $(3.4 \%)$ - only on the right side, in 1 skull $(1.1 \%)-$ on the left side (Fig. 1, Fig. 2). 
Actual problems of modern medicine. Issue 6, 2020

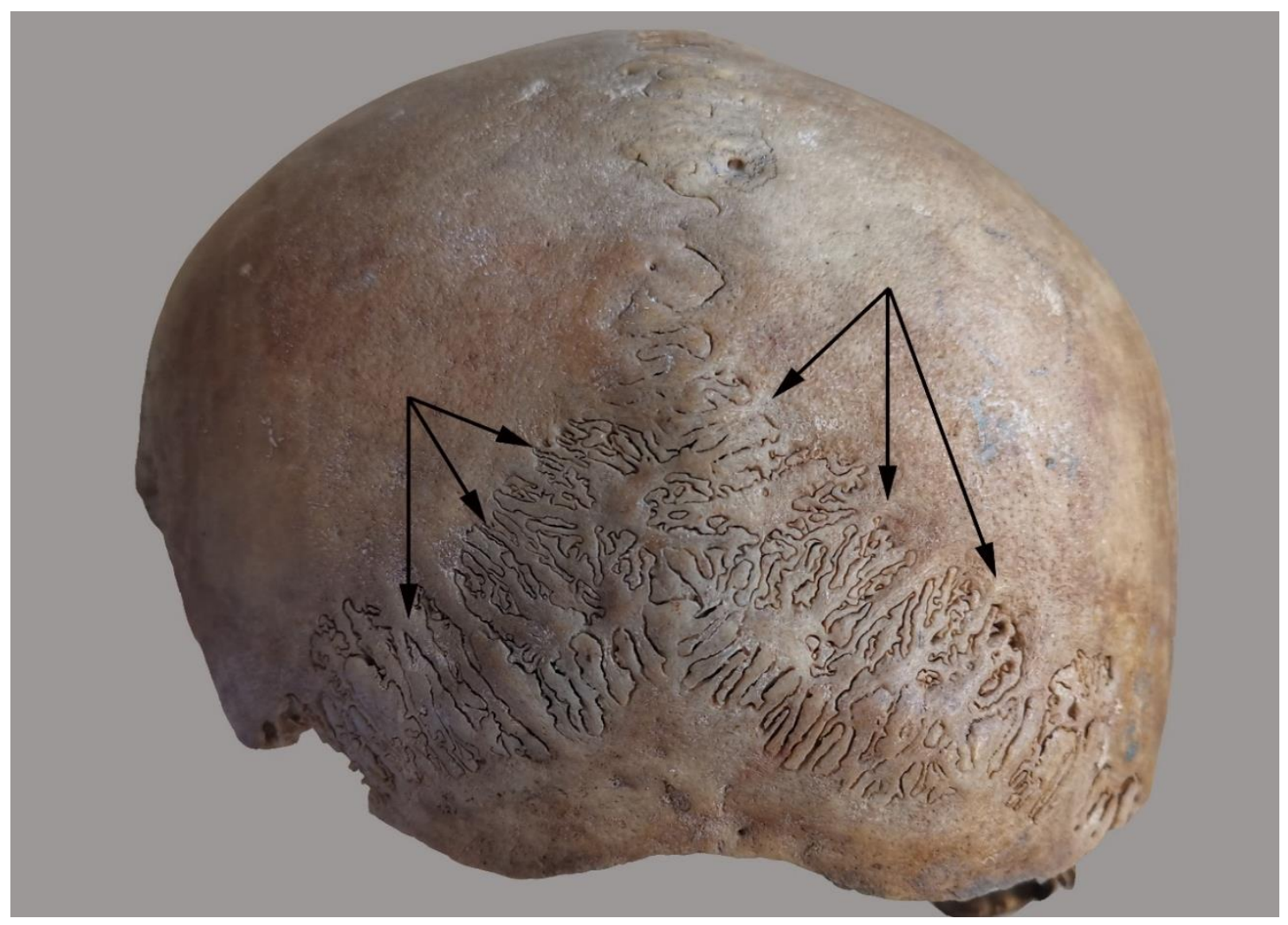

Fig. 1. Multiple inconstant wormian bones of the lambdoid suture

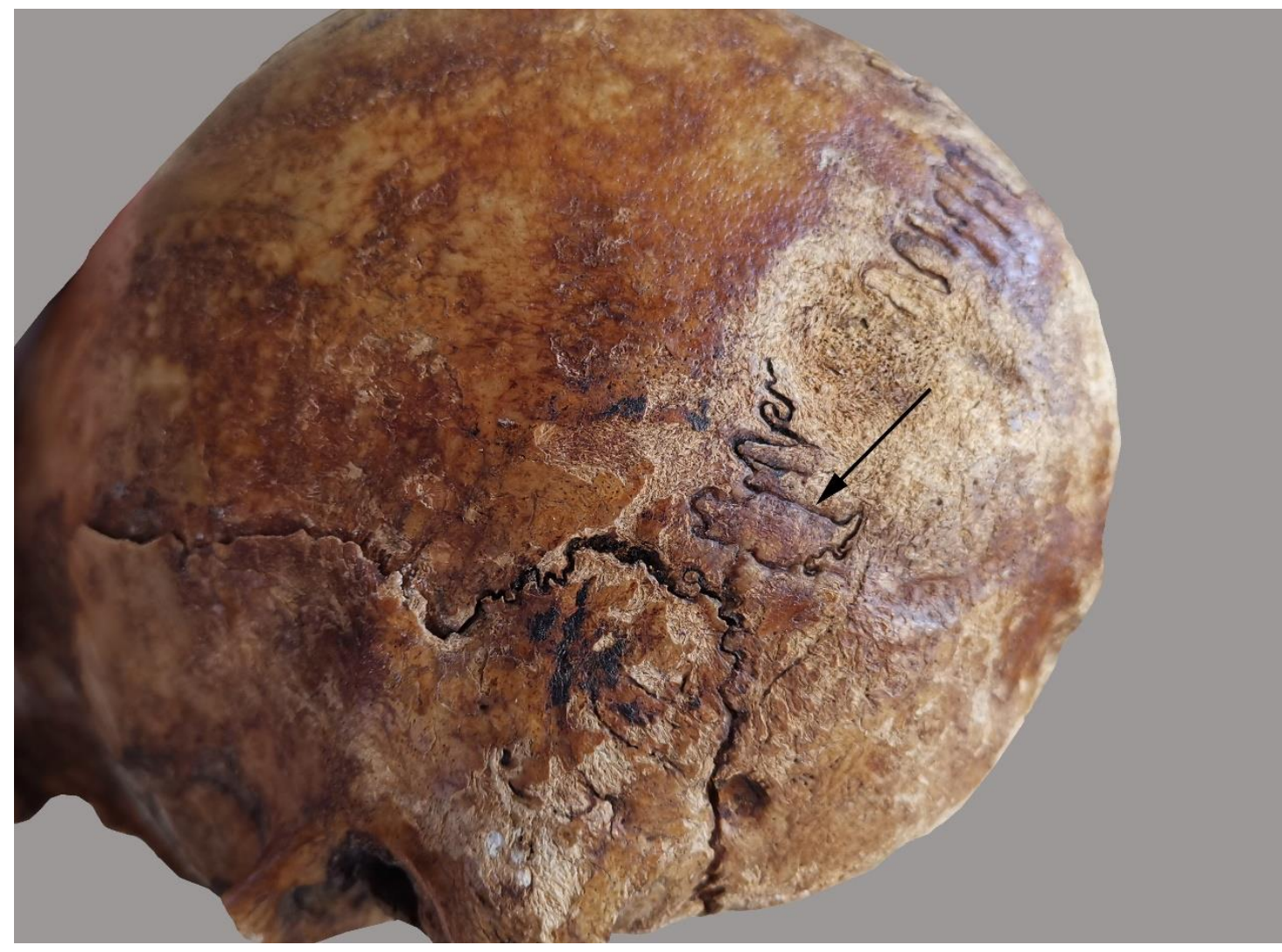

Fig. 2. Single inconstant wormian bone in left half of the lambdoid suture 
Sagittal suture wormian bones were found in structures of the 2 skulls $(2.3 \%)$. In all cases, these were single elongated bones measuring $10 \times 17 \mathrm{~mm}$ and $16 \times 33 \mathrm{~mm}$.
One of the skulls had a combination of a lost wormian bone of elongated shape, located in front of the sagittal suture with a complete metopic (frontal) suture and lost occipital fontanelle bone (Fig. 3).

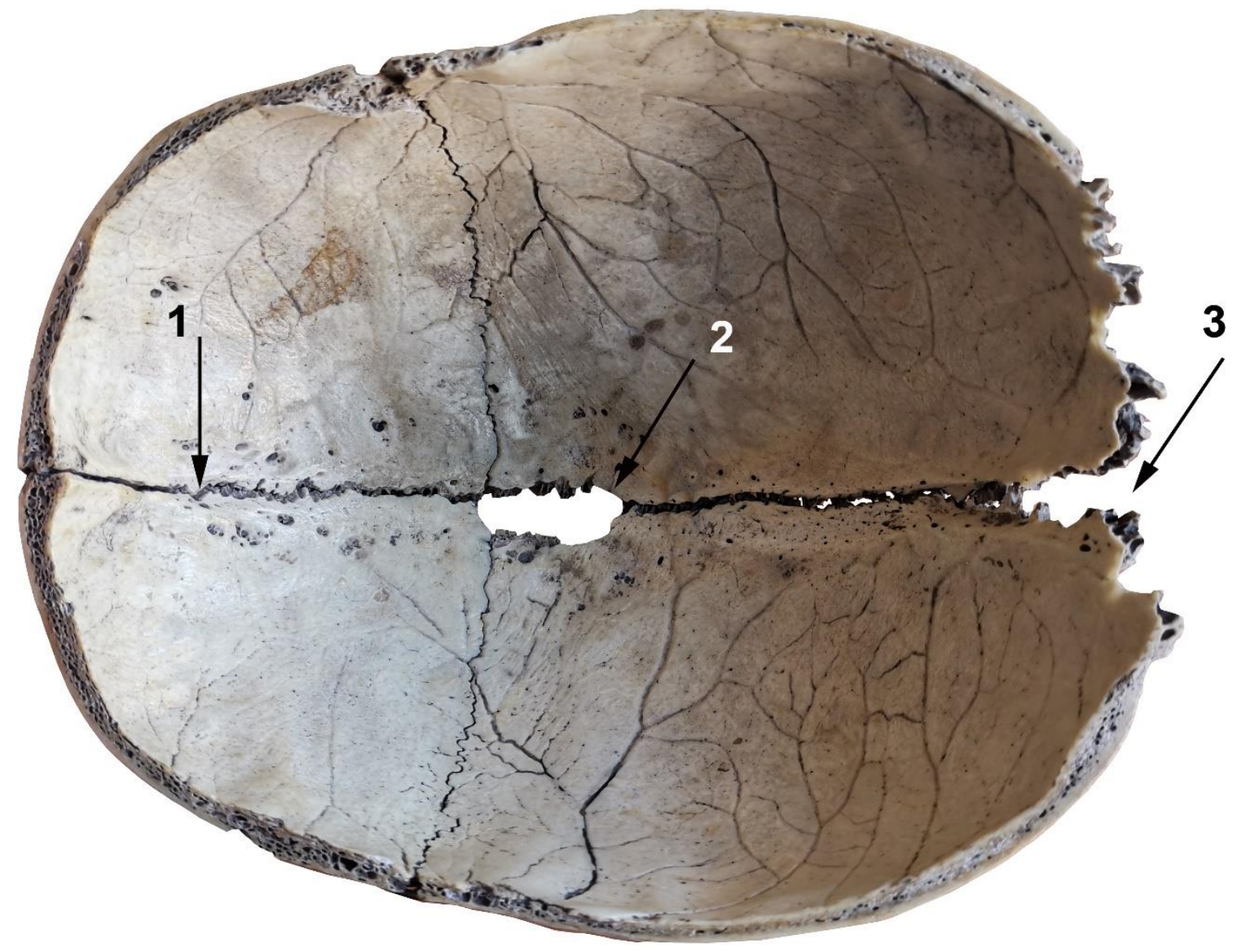

Fig. 3. The combination of a lost wormian bone in the sagittal suture (2) with complete metopic (frontal) suture (1) and lost occipital fontanelle bone (3). View from the side of the cranial cavity

The bones of the coronal suture were in the structure of 2 skulls $(2.3 \%)$. In the first case on each side of the suture was placed a single bone. The left bone was rectangular in shape, with size $11 \times 16 \mathrm{~mm}$. The left bone characterized by an elongated shape of an irregular rhombus, it size $-6 \times 12 \mathrm{~mm}$. In the second case, two small bones with an oval elongated shape and size $3 \times 5 \mathrm{~mm}$ and $4 \times 6 \mathrm{~mm}$ were placed in the right half of the suture.

The bones of the parietal-mastoid suture were present in 1 skull $(1.1 \%)$. The location of the bones was one-sided in the right suture. Two bones with size $2 \times 5 \mathrm{~mm}$ and $3 \times 10 \mathrm{~mm}$ have an elongated triangular irregular shape.
The bones of the occipital-mastoid, parietal-mastoid and squamosal sutures were absent on the examined osteological materials.

The fontanelle bones in the researched skulls were most often located at the place of the occipital fontanellele.

The occipital fontanelle bones were present in 4 skulls $(4.5 \%)$. These bones were single, triangular, quadrangular or irregular in shape. Their sizes from $8 \times 19 \mathrm{~mm}$ to $25 \times 36 \mathrm{~mm}$. One of the skulls had double occipital fontanelle bones with total size $19 \times 20 \mathrm{~mm}$.

The fontanelle bones of the mastoid fontanellele were found in structure of the 2 skulls $(2.3 \%)$. They were with elongated or irregular shape. The sizes of the bones were 
8-16 $\mathrm{mm}$. The location of these inconstant bones was bilateral in both cases.

The frontal fontanelle bone was in 1 skull $(1.1 \%)$. It was a large additional bone $13 \times 22$ $\mathrm{mm}$, with an elongated shape in the anteriorposterior direction close to the shape of a rectangle with uneven strongly "wavy" borders.

The additional fontanelle bones of the sphenoid fontanellele were not found in the researched skulls.

The interparietal bones also were not presented on the researched osteological materials.

Conclusion. By reseaching anthropological material from the grave field near the Kolomak village researched the anatomical variability of additional skull bones a separate Scythian population. In general, according to the results of the research, inconstant skull bones were present in the anatomical structure of 16 skulls out of 88 , which is $18.1 \%$ of the total. In the anatomical structure of 10 skulls $(11.4 \%)$ were only wormian bones, in 4 skulls $(4.5 \%)$ were only fontanelle bones and in the structure of 2 skulls $(2.3 \%)$ was a combination of sutural and fontanelle additional bones. Insular bones in the researched osteological material are absent. Occasionally, inconstant sutural bones were localized in several sutures at once, or combined with the fontanelle bones.

Literature data show that inconstant skull bones among representatives of various modern populations occur with a frequency of 20 to $67 \%$. Thus, the results of the research indicate that the skull with single inconstant sutural bones and additional fontanelle bones are not common variant of anatomical structure among the osteological materials from the Scythian grave field near the Kolomak village. Skulls with numerous inconstant bones are also a rare variant of the structure.

An interesting finding was the case of combination in one of the skulls of a large sagittal suture additional bone with other discrete variational features in the form of an existing complete metopic (frontal) suture (sutura frontalis s. sutura metopica) and occipital fontanelle bone. In our opinion in this case the formation of metopic suture and two large inconstant bones has been frequently associated with a non-syndromic isolated craniosynostosis. It has been often related to a chromic increase in the intracranial pressure and commonly when a midline suture (metopic or sagittal) is involved. In this case, the intracranial pressure grow gradually, occurring with the growth of the individual in childhood. In additional, the initial area in the sagittal synostosis is crucial for the direction of the increased intracranial pressure from the growing structures of the brain, anteriorly or posteriorly along the midline, coinciding with the projection of the sagittal suture. This causes the sutural widening which possibly trigger the metopic suture formation, bone formation in the sagittal suture and posterior fontanelles.

The results of the completed osteological research will expand and update the existing data on the variant anatomy of inconstant cranial bones. Further research of this variational feature and its variability on craniological materials from other osteological collections will allow to more fully characterize the structural type of a group of individuals, as well as to compare intergroup and intragroup variability, in particular among anthropological materials from different Scythian grave fields in Eastern Ukraine.

The use of data about local Scythian groups will bring us closer to understanding the origin of the Scythians, as well as the factors that determined anthropological differentiation within the Scythian population. If the main factor of this differentiation was microevolutionary, then it is unlikely to expect a special closeness of individual Scythian populations to nonscythian groups, since microevolution (including brachycephalization, gracilization, and random processes) theoretically cannot lead to convergent similarity of unrelated groups along the entire complex of characters. If such a similarity is nevertheless observed, then it, as a rule, indicates a relationship. 
Also, the restoration of morphological characteristics of osteometric features at the individual level has practical significance in archaeoanthropological reconstruction.

\section{References}

1. Bellary, SS, Steinberg, A, Mirzayan, N, Shirak, M, Tubbs, RS, et al. Wormian bones: a review. Clin Anat. 2013; 26(8):922-27. DOI: 10.1002/ca.22262

2. Cirpan S, Aksu F, Mas N. The incidence and topographic distribution of sutures including wormian bones in human skulls. J Craniofac Surg. 2015;26:1687-90. DOI: 10.1097/SCS.0000000000001933

3. Ghosh SK, Biswas S, Sharma S, Chakraborty S. An anatomical study of wormian bones from the eastern part of India: Is genetic influence a primary determinant of their morphogenesis? Anat Sci Int. 2017;92:373-82. DOI: 10.1007/s12565-016-0342-1

4. Hanihara T, Ishida H, Dodo Y. Characterization of Biological Diversity Through Analysis of Discrete Cranial Traits. Am J Phys Anthropol. 2003;121:241-51. DOI: 10.1002/ajpa.10233

5. Himabindu A, Rao BN. An insight into Wormian bones. International Journal of Scientific Research and Engineering Studies. 2015;2(6):26-8. Available from:https://www.researchgate.net/publication/279916562_an insight_into_wormian_bones_ahimabindubnarasingarao

6. Natsis K, Piagkou M, Lazaridis N, Anastasopoulos N, Nousios G, et al. Incidence, number and topography of wormian bones in Greek adult dry skulls. Folia Morphol (Praha). 2019;78:359-70. DOI: 10.4067/S0717-95022020000100069

7. Kiliç-Safak N, Taskin RG, Yücel AH. Morphologic and Morphometric Evaluation of the Wormian Bones. Int $\mathrm{J}$ Morphol. 2020;38(1):69-73. DOI:10.4067/S071795022020000100069

8. Nikolova SY, Toneva DH. Incidences of anterior fontanelle bone in cranial series from Bulgaria. J Biosci Biotechnol. 2014;special edition:145-47. http://www.jbb.uniplovdiv.bg/documents/27807/728057/SE-2014-145-147.pdf

9. Samson TD, Beals SP, Rekate HL. Massive wormian bone at the cranial apex: identification, correction and outcome. J Craniofac Surg. 2008;19(1):96-100. DOI:10.1097/scs.0b013e31815c94ad

10. Semler O, Cheung MS, Glorieux FH, Rauch F. Wormian bones in osteogenesis imperfecta: correlation to clinical findings and genotype. Am J Med Genet A. 2010;152A(7):1681-87. DOI: 10.1002/ajmg.a.33448.

11. Zaychenko AA, Zhurkin KI. Bones of sutures and fontanelleles of the human cranial [in Russian]. Saratov journal of medical scientific research. 2017;13(2):209-12. Available from:http://ssmj.ru/2017/2/209.

\title{
НЕПОСТІЙНІ КІСТКИ НА ЧЕРЕПАХ 3 СКІФСЬКОГО МОГИЛЬНИКА БІЛЯ с. КОЛОМАК
}

\author{
Шерстюк С. О., Полстяной А. О., Прохорчук Р. М.
}

Пошта для листування: andreypolstyanoj@karazin.ua

\begin{abstract}
Резюме: Дослідження особливостей варіантної анатомії людини, як важнлвої та невід'ємної частини палеоантропологічних досліджень, є ваюжлвим джсерелом додаткової інформамиї про особливості анатомічної будови людини. Краніоскопічні (дискретні варіачійні, або неметричні) ознаки, щчо являють собою анатомічні варіачії в будові черепа, реєструються за принципом «присутність-відсутність», є ваљсливи джсерелом інформації при вивченні походження і етногенетичних зв'язків палеопопулячий. До цฺих ознак відносяться втому числі непостійній (додаткові) кістки черепа. За сучасною класифікаиією прийнято виділяти З головні типи непостійних кісток черепа: шовні, тім'ячкові та островиеві кістки. Метою роботи було проведення дослідження питань варіантної анатомії непостійних кісток на черепах людей. Матеріали та методи. Була досліджена варіантна анатомія непостійни кісток на антропологічних матеріалах черепів з скіфського могильника поблизу села Коломак на Харківщині, щчо датується IX - IV cтоліттям до н.е. Було досліджсено 88 черепів дорослих людей. Результати. Непостійні додаткові кістки були присутні в будові 16 черепів, що становить 18,1\% від загальної кількості. Шовні кістки були в 12 черепах (13,6\%), тім'ячкові - у 6 черепах (6,8\%), острівцеві кістки були відсутні. У частині випадків непостійні кістки розтаповувались одночасно в декількох швах. Цікаво відмітити випадок поєднання в одному з черепів великої додаткової кістки стрілового шва з повним метопічним швом та додатковою кісткою потиличного тім'ячка. Згідно літературних даних додаткові кістки черепа зустрічаються в різни популячіях з частотою від 20 до 67\%. Висновки. Таким чином, результати дослідження вказують на те, щуо даний тип дискретно-варіаційних ознак є рідкісним варіантом анатомічної будови серед досліджених остеологічних матеріалів. Результати дослідження розимюють та доповнюють наявні дані про варіантної анатоміі непостійних кісток черепа. Подальші дослідження краніологічних матеріалів дозволять більи повно та дослідити порівнювальнувнутрішньогрупову та міжсгрупову мінливість.
\end{abstract}

Ключові слова: непостійні кістки черепа, шовні кістки, тім’ячкові кістки, варіантна анатомія людини, палеоантропологія

\footnotetext{
Інформація про авторів

Шерстюк Сергій Олексійович,

людини Харківського національного

майдан Свободи, 6, Харків, Україна, д. мед. н., проф., зав. кафедри анатомії університету імені В. Н. Каразіна, 
Actual problems of modern medicine. Issue 6, 2020

e-mail: anatomy@karazin.ua https://orcid.org/0000-0001-6062-7962

Полстяной Андрій Олександрович, асистент кафедри анатомії людини Харківського університету імені В. Н. Каразіна, майдан Свободи, 6, Харків, Україна, 61022

e-mail: andreypolstyanoj@ karazin.ua https://orcid.org/0000-0002-6513-1533

Прохорчук Роксолана Миколаївна, асистент кафедри анатомії людини
Харківського національного університету імені В. Н. Каразіна, майдан Свободи, 6, Харків, Україна, 61022

e-mail: prokhorchuk@karazin.ua https://orcid.org/0000-0002-7194-5584

\title{
НЕПОСТОЯННЫЕ КОСТИ НА ЧЕРЕПАХ СКИФСКОГО МОГИЛЬНИКА ОКОЛО с. КОЛОМАК
}

\author{
Шерстюк С. А., Полстяной А. А., Прохорчук Р. Н.
}

Пошта для листування: andreypolstyanoj @karazin.ua

Резюме. Исследования особенностей вариантной анатомии человека, как важная и неотъемлемая части палеоантропологических исследований, являются источником дополнительной информации об особенностях строения человека. Краниоскопические (дискретные вариационные, или неметрические) признаки, представляющие анатомические вариации в строении черепа, регистрируемые по принципу «присутствие-отсутствие», являются важным источником информации при изучении происхождения и этногенетических связей палеопопуляций. Одним из данных признаков являются непостоянные или добавочные кости черепа. Согласно современной классификации, выделяют три главных типа непостоянных костей черепа: шовные, родничковые и островковые кости. Целью работы было исследование особенностей непостоянных костей на черепах людей. Материалы и методы. Была изучена вариантная анатомия непостоянных костей на антропологических материалах черепов из скифского могильника вблизи села Коломак в Харьковской области, датируемого IX - IV веком до н.э. Было исследовано 88 черепов взрослых людей. Непостоянные дополнительные кости присутствовали 8 строении 16 черепов, что составляет 18,1\% от общего количества. Результаты. Шовные кости были в 12 черепах $(13,6 \%)$, родничковые - в 6 черепах (6,8\%), островковые кости не были обнаружены. В ряде случав непостоянные кости располагались одновременно в нескольких швам. Интересным является случай сочетания в одном из черепов крупной добавочной кости сагиттального шва с полныли метопическим швом и дополнительной костью затылочного родничка. Согласно литературным данным, добавочные кости черепа встречаются в различных популяциях с частотой 20-67\%. Выводы. Таким образом, результаты исследования указывают на то, что данный тип вариачионно-дискретных признаков является редким вариантом строения черепа среди исследованных остеологических материалов. Результаты исследования в значительной степени дополняют и расширяют существующие данные об особенностях вариантной анатомии добавочных костей черепа. Дальнейшие исследования краниологичних материалов могут позволить изучить сравнительную внутригрупповую и межгрупповую изменчивость.

Ключевые слова: непостоянные кости черепа, шовные кости, родничковые кости, вариантная анатомия человека, палеоантропология

\section{Информация об авторах}

Шерстюк Сергей Алексеевич, д. мед. н., проф., зав. кафедрой анатомии человека Харьковского национального университета имени В.Н. Каразина, пл. Свободы, 6, Харьков, Украина, 61022 e-mail: anatomy@karazin.ua https://orcid.org/0000-0001-6062-7962
Полстяной Андрей Александрович, ассистент кафедры анатомии человека Харьковского национального университета имени В. Н. Каразина, пл. Свободы, 6, Харьков, Украина, 61022 e-mail: andreypolstyanoj@karazin.ua https://orcid.org/0000-0002-6513-1533
Прохорчук Роксолана Николаевна, ассистент кафедры анатомии человека Харьковского национального университета имени В. Н. Каразина, пл. Свободы, 6, Харьков, Украина, 61022 e-mail: prokhorchuk@karazin.ua https://orcid.org/0000-0002-7194-5584

Conflicts of interest: author has no conflict of interest to declare.

Конфлікт інтересів: відсутній.

Конфликт интересов: отсутствует. 


\title{
ОГЛЯДОВА СТАТТЯ
}

\section{УДК 613.6.027;159.946:78.07 \\ DOI: $10.26565 / 2617-409 X-2020-6-10$ \\ «ПЕРЕИГРАННАЯ РУКА» ИЛИ СИНДРОМЫ ПЕРЕНАПРЯЖЕНИЯ У МУЗЫКАНТОВ. ЧАСТЬ ІІ: ПРОФИЛАКТИКА И ЛЕЧЕНИЕ}

\author{
Березуцкий В. И., Березуикая М. С.
}

Пошта для листування: Berezut@ua.fm

\begin{abstract}
Резюме: Травмы перенапряжения втречаются у 50-85 \% музыкантов-инструменталистов $u$ проявляются в тендовагинитах, бурситах и туннельных синдромах, что ведет к длительной временной утрате трудоспособности (а в тяжельх случаях - к стойкой). Для Украины проблема обладает особой актуальностью по нескольким причинам: во-первых, исследования профессиональных заболеваниях музыкантов в стране в последние десятиления не проводились; во-вторых, в стране очень большое количество музыкальных учебных заведений, но ни в одном из них будущих музыканов не обучают профилактике профессиональных заболеваний; в-третьих, в стране нет специализированных медицинских иентров для лечения профессиональной патологии музыкантов. Целью исследования был анализ последних достижений в диагностике, лечении и профилактике травм перенапряжения $у$ музыкантов. Анализу были подвергнуты исследования, опубликованные в 2016-2020 г2. в журналах, индексирующихся в наукометрических базах Scopus, WoS, MedLine u PubMed. Установлено, что эффективная профилактика травм перенапряжения у музыкантов возможна лишь при комплексном подходе, предполагающем реорганизачию музыкального образования и медицинского обеспечения профессиональной деятельности музыкантов-инструменталистов. Для формирования эргономичной исполнительской техники, а также обеспечения будущих музыкантов знаниями и навыками по сохранению здоровья в условиях своей профессии, необходимо введение в учебные планы соответствующей дисииплины, преподавание которой должно вестись при участии специалистов по физической реабилитации и физической культуре. Для обеспечения эффективного лечения профессиональных травм у музыкантов необходимо создание спеииализированного республиканского реабилитационного центра, а также расширение программы подготовки врачей хирурговтравматологов и реабилитологов на этапе последипломного образования за счет тематических курсов повышения квалификации.
\end{abstract}

Ключевые слова: профессиональные болезни музыкантов, травмы перенапряжения, «переигранная рука», эргономичная исполнительская техника

\section{Информация об авторах}

Березуикий Владимир Иванович, к. мед. н., доц. кафедры пропедевтики внутренней медицины ГУ Днепропетровская медицинская

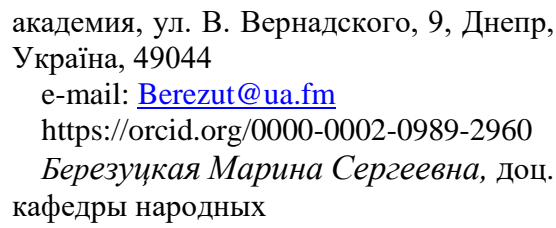

\author{
инструментов Днепропетровской \\ академии музыки им. М. Глинки; ул. \\ Литейная, 10, Днепр, Україна, 49044 \\ e-mail: Bermarser@gmail.com \\ https://orcid.org/0000-0002-5511-2195
}

Вступление. Синдромы перенапряжения (СП) - весьма распространенная среди музыкантов-инструменталистов группа поражений мышечно-связочного аппарата, обусловленных многократным повторением однообразных движений или длительным статическим напряжением определенной группы мышц. Нередко СП, обусловленные профессиональной деятельностью музыкантов, называют «профессиональными заболеваниями рук музыкантов» (ПЗРМ).
Патогенез ПЗРМ связан с целым комплексом факторов: нефизиологическая исполнительская техника и неэргономичная поза, определяющие неравномерное распределение нагрузки на группы мышц, задействованных при игре на музыкальном инструменте, избыточная по продолжительности практика непрерывной игры на инструменте, анатомофизиологические особенности исполнителя, создающие предрасположенность к ПЗРМ 
(нарушения объема движений в суставах в виде гипо- или гипермобильности, слабость мышечно-связочного аппарата, маленькие руки с короткими пальцами), низкая физическая активность музыкантовинструменталистов, не обеспечивающая необходимый для предупреждения травм перенапряжения уровень развития мышц плечевого пояса и позвоночника, низкая информированность музыкантов в вопросах патогенеза и профилактики ПЗРМ, обусловленная отсутствием соответствующих дисциплин в учебных планах.

Актуальность изучения проблемы профилактики и лечения СП у музыкантов обусловлена высокой распространенностью патологии; отсутствием в Украине научных исследований в данной области; отсутствием специализированной медицинской помощи больным с ПЗРМ; несовершенством системы музыкального образования. Систематизация опыта европейских и американских специалистов позволила бы расширить профессиональный кругозор специалистов, сталкивающихся с проблемой ПЗРМ и разработать систему профилактики.

Целью настоящего исследования является систематизация информации о методах профилактики и лечения СП у музыкантов на основании анализа научной литературы.

Материалы и методы. Для достижения цели был проведен поиск научной литературы, посвященной профилактике и лечению СП у музыкантов. Поиск проводился в изданиях, индексируемых в наукометрических базах Scopus, WebOfScience, MedLine и PubMed за период 2016-2020 гг. Для поиска использовались следующие сочетания ключевых слов: overused syndromes, musicians; a repetitive strain injury, musicians; overuse injuries, musicians; cumulative trauma disorders, musicians; playing-related musculoskeletal disorders, musicians; playing-related musculoskeletal problems, musicians; а также русскоязычные и украино-язычные смысловые аналоги: синдромы перенапряжения $y$ музыкантов; профессиональные заболевания у музыкантов; «переигранная рука».

\section{Результаты \\ Подходы к профилактике и лечению. Формирование (эргономической) \\ безопасной исполнительской}

техники. Многие педагоги-инструменталисты прививают своим ученикам эргономический стиль исполнения, используя Alexander Technique. Методика существует уже более полувека и названа в честь ее создателя австралийского актера и педагога актерского мастерства Frederick Matthias Alexander (18691955). Изначально Alexander Technique предназначалась автором для «развития пространственного сознания» и «улучшения ментального и физического благополучия путем обучения избавлению от плохих привычек» (в первую очередь - от двигательных стереотипов и неблагоприятных поз). Однако музыканты-инструменталисты довольно быстро адаптировали ее к своим нуждам, включая в образовательный процесс музыканта упражнения, обеспечивающие расслабление мышц, перегруженных в «профессиональных позах» во время репетиций [1].

Alexander считал, что оптимальный сенсорно-моторный контроль музыканта достигается динамической реакцией на меняющиеся потребности в мышечном тонусе, гибкости и силе. Alexander придавал большое значение подавлению стрессовых реакций и развитию конструктивных моделей мышления и движения, он был убежден, что такие стратегии потенциально изменяют способ воспроизведения музыки и помогают совершенствованию профессионального мастерства исполнителя [2]. В 2020 году были опубликованы результаты применения Alexander Technique в консерватории Сиднея (Австралия) на протяжении одного года: позитивные результаты были у 87 \% студентов, они выражались в снижении выраженности болевого синдрома (в среднем на $40 \%$ по шкале боли) у студентов с СП. Также было доказано улучшение качества жизни, снижение уровня тревожности, уменьшение пропусков занятий по болезни, повышение академической успеваемости [3].

Логическим продолжением Alexander Technique является «методика картографирования тела» (Body mapping 
approach). Метод был разработан виолончелистом и преподавателем Alexander Technique - William Conable для обучения музыкантов тому, как двигаться в соответствии с особенностями анатомического строения своего тела, чтобы предотвратить травмы и усовершенствовать исполнительское мастерство. Методика была с успехом внедрена в 2018 году в учебные планы музыкального колледжа при Университете в Блумфонтейне (ЮАР) [4].

Известная американская скрипачка Karen Tuttle на основе физиологии двигательной системы и своего богатого педагогического опыта создала методику обучения, направленную на формирование безопасной для здоровья исполнительской техники. Karen Tuttle назвала методику «Coordination», в еe основе - развитие у музыканта чувства собственного тела («своеобразный кинестетический интеллект»), обеспечивающего исключение напряжения не задействованных при исполнении групп мышц. Особенностью методики является ее персонализация: учет анатомофизиологических и психологических особенностей каждого исполнителя. Многие исследователи считают, что техника Karen Tuttle является частным вариантом применения теории Alexander для скрипачей [5]. Karen Tuttle разработала «контрольный лист» для оценки координации исполнителя, учитывающий даже стиль исполняемого музыкального произведения (джаз, фолк, классика). Конкретные указания по развитию кинестетического контроля за группами мышц (по картографическому описанию) во время исполнения позволяли исполнителю обучится физически «чувствовать джаз в теле».

\section{Повышение}

информированности

музыкантов. Междисциплинарная команда немецких ученых выполнила в 2019 году масштабный аналитический обзор исследований, посвященных проблеме СП у музыкантов: в общей сложности было проанализировано более двух десятков исследований (более 5000 музыкантовинструменталистов). Исследователи признали, что сколько-нибудь эффективной системы профилактики и лечения поражений скелетномышечной системы у музыкантов на данный момент не существует. Более того, даже теоретическая основа для таких систем все еще не выработана [4].

Для решения данной проблемы международная организация Всемирная сеть университетов (Worldwide Universities Network) создала проект «Медико-санитарная грамотность и доступность для музыкантов: глобальный подход» (Health education literacy and accessibility for musicians: a global approach) с целью повышении медицинской грамотности музыкантов на протяжении всей их карьеры. Была сформирована совместная международная междисциплинарная исследовательской группа, перед которой была поставлена задача разработать многоплановую исследовательскую программу для создания гибких и доступных подходов к санитарному просвещению для музыкантов. Первые же результаты работы группы выявили необходимость как организационных изменений в музыкальном образовании, так и повышения уровня медицинской грамотности у музыкантов во всем мире [6]. Однако практическая реализация реорганизации музыкального образования оказалась не таким простым делом. Специалисты по физической реабилитации факультета Наук о здоровье Витвотесрандского Университета в Йоханесбурге (ЮАР) изучали факторы, способствующие и препятствующие внедрению в учебные планы студентовструнников программы профилактики травм перенапряжения, основанной на физических тренировках. Не смотря на позитивное восприятие самой программы еe предполагаемыми участниками, выяснилось, что для еe эффективного применения необходимо уменьшить количество часов для занятий по основной специальности [7].

Ученые Великобритании уже в 2018 году представили первый опыт внедрения специальных знаний и навыков по профилактике ПЗРМ в образовательные программы студентов консерваторий. Для всех студентов-первокурсников нескольких консерваторий Великобритании был введен курс дисциплины «Health and Wellbeing for Musicians». Курс состоял из десяти еженедельных микромодулей: как заниматься более эффективно (игрой на инструменте); как 
более эффективно репетировать; методы самоконтроля и управления поведенческими реакциями; анатомия и физиология для музыкантов; управление психологическим и эмоциональным состоянием во время репетиций и публичных выступлений; исполнительские навыки; и др. Занятия проводили опытные педагогиинструменталисты, специалист по профилактике и лечению профессиональных заболеваний, медицинский психолог, специалист по медицинскому сопровождению исполнительских искусств. На лекциях студенты знакомились с причинами, механизмами возникновения и проявлениями профессиональных заболеваний музыкантов, а также с методами их профилактики. На практических занятиях они обучались методам контроля своего психологического и физического состояния во время различных видов профессиональной деятельности, а на семинарских занятиях эти полученные знания и навыки оценивались организаторами курса. Студенты, прошедшие курс, оценили свою способность справляться с соответствующими проблемами здоровья и безопасности значительно выше, чем студенты контрольной группы (более чем на 55\%). На академической успеваемости (рейтинги) влияния новой дисциплины не было обнаружено, но количество пропущенных по болезни учебных дней было на $25 \%$ меньше в основной группе студентов. Также было выявлено существенное снижение тревожности у студентов основной группы (более чем на $35 \%$ ) и, что самое главное - частоты СП [8].

\section{Перспективные} совершенствования музыкантов

\section{исполнительской}

Оснабрюкского Университета прикладных наук (Германия) установили, что используемые в настоящее время различные биомеханические измерительные приборы для сбора двух- и трехмерных кинематических данных (оптоэлектронные системы с активными и пассивными маркерами, электромагнитные системы, ультразвуковые системы анализа движения на основе изображений, электромиография) позволяют выявить физиологические неблагоприятные движения музыкантов-струнников [9]. Именно эти технологии позволили разработать основанный на маркерах метод анализа трехмерного движения верхней части тела скрипачей и альтистов. Метод улучшает понимание двигательных стратегий, используемых игроками с высокими струнами, и может способствовать профилактике профессиональных травм [10]. Ученые Технологического Массачусетского Института (США) в 2020 году разработали компьютерную систему для автоматической оценки положения руки пианиста, предназначенную для помощи начинающему пианисту в освоении эргономически безопасной исполнительской техники. Система состоит из компьютерного видеоанализатора (3-Д камеры), воспринимающего движения рук музыканта, и программного обеспечения, обрабатывающего полученную с анализатора информацию. Модели обнаружения и оценки движения рук исполнителя оцениваются системой индивидуально благодаря использованию технологии векторного анализа движения 3-Д изображений. Система представляет результаты анализа в удобной для восприятия студентом и его педагогом форме [11].

Физические упражнения. По своему патогенезу СП у музыкантов существенно не отличаются от травм перенапряжения у спортсменов. На этом бесспорном факте основываются многочисленные попытки применить уже апробированные в спорте методики для предупреждения СП у музыкантов. Ученые из консерватории при Университете в Аделаиде (Австралия) выполнили сравнительный анализ подходов к профилактике травм перенапряжения, применяемых в спортивной и музыкальной педагогике. Было установлено, что спортсмены (по-сравнению с музыкантами) гораздо лучше информированы о факторах риска и механизмах возникновения СП, а также имеют более свободный доступ к специализированной медицинской помощи. Анализ показал целесообразность использования достижений спортивной медицины и педагогике в сфере музыкального образования [12]. Междисциплинарная команда австралийских ученых их 
Университета Сиднея при помоши электромиографического изучали влияние исследования «разогревающих» физических упражнений на функциональное состояние скелетной мускулатуры и сердечнососудистой системы, а также на исполнительскую технику большой группы профессиональных скрипачей. Оценивалась поверхностная электромиограмма с 16 мышц туловища, шеи, плеч и правой руки в покое, во время 15-минутной «разогревающей» разминки и в течение 45-минутного исполнения, а также после него. Одновременно производилась аудиозапись, которая в последующем оценивалась специалистами «вслепую». Исследование повторялись трижды с различными протоколами разминки (в разные дни). По сравнению с группой контроля было выявлено усиление мышечной активности во время исполнения и ускорение восстановления показателей после. Позитивный эффект был выявлен также в отношении исполнительского мастерства [13].

Опрос студентов-инструменталистов Школы Музыки при Мичиганском Университете (США) показал, что СП в 5 раз реже развиваются у студентов, имеющих обыкновение выполнять «разогревающие» упражнения перед занятиями за инструментом, а также делать перерывы для отдыха каждые 30 минут [14]. Ученые Витватерсрандского университета (ЮАР) в ходе анализа 176 исследований применения физических упражнений для профилактики СП у музыкантов установили, что наиболее эффективными являются упражнения на растяжку перед исполнительской практикой, а также проприоцептивные упражнения по контролю моторики [15]. Турецкие специалисты по физической реабилитации из Университета Хасеттепе в Анкаре изучали влияние физических упражнений на эффективность лечения СП у студентовмузыкантов (инструменталистов) с гипермобильностью суставов верхних конечностей. Они установили, что систематическое выполнение физических упражнений, стабилизирующих объем движений в суставах, уже через 1 месяц дает существенное улучшение. Большая группа студентов с гипермобильностью суставов верхних конечностей месяц занималась физическими упражнениями. Средний балл по шкале DASH (Disabilities of the Arm, Shoulder and Hand) у музыкантов снизился с 25,12 до $10,23(\mathrm{P}<0,05)[16]$.

Специалисты по профессиональной патологии и физической реабилитации из Маастрихтского университета (Нидерланды) в многоцентровом рандомизированном контролируемом исследовании с участием 175 студентов-музыкантов

эффективность двух разных программ профилактики нарушений опорнодвигательной системы. Первую программу исследователи назвали «биопсихосоциальной профилактикой»: студенты на протяжении года прошли курс практических занятий, обучающих эргономически безопасной осанке тела для исполнительской практики, включающих обучение постуральной лечебной гимнастике и основам биомеханики движения, а также самоконтролю психологического состояния во время репетиций и концертов. Вторая программа состояла из занятий физической культурой в соответствии с национальными рекомендациями. Студенты ежедневно выполняли стандартный комплекс упражнений по укреплению опорно-двигательного аппарата. По результатам двухгодичного наблюдения оценивалось состояние костномышечной системы, частота развития и выраженность проявлений СП (связанных с исполнительской практикой). Было установлено, что обе программы оказались равноценно эффективны в профилактике СП: по сравнению с общей популяцией студентовмузыкантов частота СП снизилась почти в 2 раза [17].

Специалисты факультета физической терапии Каролинского Медицинского Университета в Худдинге (Швеция) изучали возможности применения физических тренировок с сопротивлением (resistance training) для профилактики СП у профессиональных музыкантов-струнников. Группа виолончелистов и скрипачей из трех симфонических оркестров выполняли упражнения два раза в неделю в течение трех месяцев. Контрольные исследования показали, что показатели изометрической силы мышц 
спины, шеи, плеч, предплечий и запястья у музыкантов выросли в среднем на 19\%, а показатели изометрической выносливости - на 25\% ( p <0,05). Кроме того, у 59\% музыкантов нормализовался объем пассивных и активных движений в задействованных суставах (при исходной гипер- или гипомобильности), а также улучшилась исполнительская техника. Годичное проспективное наблюдение показало снижение выраженности симптоматики СП в среднем на $50 \%$ [18].

Комплексные программы профилактики. В последние годы именно эти программы показали наибольшую эффективность. Разработанная в 2019 году Музыкальном колледже Вашингтонского Университета (США) программа профилактики профессиональных травм у музыкантов-инструменталистов предполагает три основных положения: интеграцию программы санитарного просвещения в учебные планы студентов-музыкантов; совершенствование системы физического воспитания; организацию системы специализированной медицинской помощи студентам-музыкантам [19]. Специалисты по профессиональным заболеваниям музыкантов из Университета Южной Каролины (США) в 2019 году представили комплексную программу реабилитации музыкантов с СП, основанную на формировании эргономической исполнительской техники, и предложили варианты еe интеграции в практическое здравоохранение. Программа предусматривает учет специфики исполнительской деятельности музыкантов-инструменталистов различных групп, а также сохранение профессиональных нагрузок ограничениями) на весь период реабилитации. Программа включает диагностическую часть: оценка характера и степени выраженности у музыканта нарушений биомеханики профессиональных движений, и лечебную физические упражнения, восстанавливающие функцию пораженных мышечно-сухожильных групп [20].

Профессиональные нагрузки в острую фазу травматического перенапряжения. Исключительно важным для музыкантов с уже развившейся травмой перенапряжения является вопрос: можно ли продолжать играть, не смотря на боль? Обычно травматологи запрещают играть на весь период реабилитации, а нередко пораженную конечность фиксируют при помощи лангеты или гипсовой повязки. Основываясь на анализе междисциплинарных исследований проблемы последних лет, ученые Университета Аделаиды (Австралия) в 2020 году пришли к заключению: полный отказ от исполнительской практики на время болезни несет определенные негативные последствия, поскольку обусловлен стратегией избегания страха. Кроме того, авторы указывают на иные негативные последствия:

утрату профессионального мастерства или задержку в развитии, финансовые потери, угнетенное эмоциональное состояние [21].

Известный гитарист Lorenzo Fugazza в 2020 году выполнил при Королевском Колледже Музыки в Стокгольме исследование на тему «Methods to support guitarists to recover from injuries and/or maintain health» [22]. Работа опирается на огромнейший опыт Института Физиологии и Медицины Искусства в Барселоне. Стратегия реабилитации предполагает восемь положений. Первое временные ограничения для исполнительской практики: 5-минутные перерывы каждые 25 минут для отдыха и упражнений на растяжку. Второе - - дифференцирование исполнительской практики: чередование произведений, требующих нагрузки на различные мышечно-суставные группы. Третье - качество, а не количество исполнительской практики. Четвертое: строгое соблюдение эргономически обоснованной структуры занятия: постепенное увеличение нагрузки на задействованные в игре мышцы и связки (что обеспечивает постепенный их прогрев). Пятое прогрессирующее ежедневное наращивание нагрузки. Была разработана последовательность предварительно записанных треков, фиксированных по скорости воспроизведения (темпу) при помощи метронома. $\mathrm{C}$ каждым днем темп увеличивается на 1 удар метронома в минуту, что мало заметно для проходящего реабилитацию музыканта, но вместе с тем обеспечивает безопасное восстановление прежнего уровня нагрузок. Шестое - 
чередование активных и пассивных методов восстановления: перед каждым занятием 5 минут растяжки, в которой основное внимание уделяется сгибателям и разгибателям пальцев. На каждую минуту активной практики должна приходиться 1 минута пассивного или активного отдыха. Под активным отдыхом предполагается физическая нагрузка, задействующая иные, чем при игре на инструменте, группы мышц. Седьмое вводный и текущий контроль занятий со стороны реабилитолога. Восьмое обязательное использование физиотерапии. Статистика Institut de 1'Art показывает, что без физиотерапии восстанавливаются лишь $60 \%$ предтравматических навыков и способностей, в то время как с участием врачафизиотерапевта этот показатель увеличивается до $85-90 \%$, что можно считать полным выздоровлением.

Заключение. Травмы перенапряжения у музыкантов - это сложная междисциплинарная проблема, эффективное решение которой возможно лишь при междисциплинарном подходе. Выполненный анализ последних научных и практических разработок по проблеме профилактики СП у музыкантов показывает, что наиболее эффективным является комплекс мероприятий:

во-первых, реорганизация системы музыкального образования, обеспечивающая будущего музыканта знаниями и навыками, необходимыми для сохранения здоровья в условиях его профессиональной деятельности;

во-вторых, расширение программы обучения врачей-реабилитологов за счет знаний и навыков, необходимых для работы с СП у музыкантов;

в-третьих, создание специализированного реабилитационного центра для музыкантов по аналогии с «Украинским Центром Реабилитации Спортсменов», созданным в 2016 году на базе Учебно-научного медицинского комплекса «Университетская клиника» Харьковского национального медицинского университета. Подобный центр для музыкантов мог бы сотрудничать с аналогичными зарубежными медицинскими центрами и взять на себя работу по повышению квалификации практикующих травматологов и реабилитологов.

На начальном этапе эффективной будет популяризация в среде врачей и музыкантов наиболее современных знаний о профилактике и лечении переигранной руки. Поскольку данная проблема присуща не только музыкантам и спортсменам, но и многим другим профессиональным группам, имеющим аналогичные факторы риска, то профилактические и лечебные техники, основанные на опыте музыкальных педагогов, могут иметь более широкое применение. Успешное заимствование музыкальной педагогикой опыта спортивной медицины предполагает и обратный процесс: опыт музыкальной педагогики в формировании эргономического исполнительского стиля может быть применим как в спорте, так и в производственной медицине.

\section{Список литературы}

1. Chapman S. The Alexander technique in relation to practising, performing and teaching. Bulletin of the Transilvania University of Braşov, Series VIII: Performing Arts. 2019;12(2):7-12. doi:10.31926/but.pa.2019.12.61.11.

2. Staring J. Frederick Matthias Alexander, Born 150 Years Ago, on January 20, 1869. A Fierce Comment Regarding Interpretations of Alexander's Texts by Alexander Technique Teachers. Case Studies Journal. 2018;7(12):107-108.

3. Davies J. Alexander Technique classes improve pain and performance factors in tertiary music students. Journal of Bodywork and Movement Therapies. 2020;24(1): 1-7. doi:10.1016/j.jbmt.2019.04.006.

4. Salonen B L. Tertiary music students' experiences of an occupational health course incorporating the body mapping approach: dissertation. Bloemfontein: Odeion School of Music of the Free State University; 2018.

5. Napier E. Fostering Freedom: A Holistic Comparison of Karen Tuttle's Ideas with Body Mapping and the Alexander Technique: dissertation. Ann Arbor: University of Michigan; 2019.

6. Baadjou VA, Wijsman SI, Ginsborg J, Guptill C, de Lisle R, Rennie-Salonen B. Health education literacy and accessibility for musicians: a global approach. Report from the Worldwide Universities Network project. Medical problems of performing artists. 2019;34(2):105-107. doi:10.21091/mppa.2019.2011.

7. Ajidahun AT, Myezwa H, Mudzi W, Wood W. Barriers and facilitators in implementing an exercise-based injury prevention program for string players. Work. 2019;64(3): 713-720. doi: 10.3233/WOR-193033.

8. Matei R, Broad S, Goldbart J, Ginsborg J. Health education for musicians. Frontiers in psychology. 2018:9: 1137-1146. doi:10.3389/fpsyg.2018.01137.

9. Schemmann H, Rensing N, Zalpour C. Musculoskeletal Assessments Used in Quantitatively Based 
Studies About Posture and Movement in High String Players. MPPA. 2019;33(1):56-71. doi: 10.21091/mppa.2018.1009.

10. Wolf E, Möller D, Ballenberger N, Morisse K, Zalpour C. Marker-Based Method for Analyzing the ThreeDimensional Upper Body Kinematics of Violinists and Violists. Med Probl Perform Art. 2019;34(4):179-190. doi: 10.21091/mppa.2019.4029.

11. Johnson D, Damian D, Tzanetakis G. Detecting Hand Posture in Piano Playing Using Depth Data. Computer Music Journal, 2020;43(1): 59-78. doi:10.1162/COMJ a 00500 .

12. Stanhope J. Physical performance and musculoskeletal disorders: Are musicians and sportspeople on a level playing field? Performance Enhancement \& Health. 2016;4(1-2): 18-26. doi:10.1016/j.peh.2015.11.004. 13. McCrary JM, Halaki M, Sorkin E, Ackermann BJ. Acute warm-up effects in submaximal athletes: An EMG study of skilled violinists. Med Sci Sports Exerc. 2016;48(2): 307-315. doi: 10.1249/MSS.0000000000000765.

14. Savvidou P, Stanek J. Playing-Related Pain and Associated Habits Among Students and Faculty at a Major University Music Program: A Study of Prevalence with Recommendations for Teachers. MTNA e-Journal. 2019;11(1): 2-12.

15. Ajidahun A T. Myezwa H, Mudzi W, Wood W. A scoping review of exercise intervention for playing-related musculoskeletal disorders (PRMDS) among musicians. Muziki. 2019; 16(1): 7-30. doi:10.1080/18125980.2019.1606675.

16. Akel BS, Aran OT, Öksüz Ç. The Effect of Stabilization Exercises on Playing Performance in Musicians With Joint Hyperlaxity. HAND. 2016;11(1): 137-139. doi:10.1177/1558944716660555jo.

17. Baadjou V, Verbunt J, van Eijsden-Besseling F, de Bie R, Girard O, Twisk J, Smeets R. Preventing musculoskeletal complaints in music students: a randomized controlled trial. Occupational Medicine. 2018;68(7): 469477. doi:10.1093/occmed/kqy105.

18. Lundborg B, Grooten WJ. Resistance training for professional string musicians: a prospective intervention study. Medical problems of performing artists. 2018; 33(2), 102-110. doi: 10.21091/mppa.2018.2017.

19. Hale G. Playing with Pain: Injury Prevention Strategies for Music Schools in the United States: diss. Washington: Washington American University; 2019.

20. Ting A, Rocker J. Evaluation and Treatment of Musicians from a Holistic Perspective. The Open Journal of Occupational Therapy. 2019;7(4):1-10. doi:10.15453/21686408.1581.

21. Stanhope J, Weinstein P. Should musicians play in pain? British Journal of Pain. 2020: 2049463720911399. doi: $10.1177 / 2049463720911399$.

22. Fugazza L. Methods to support guitarists to recover from injuries and/or maintain health: dissertation. Kungl: Musikhögskolan; 2020.

\section{References}

1. Chapman $\mathrm{S}$. The Alexander technique in relation to practising, performing and teaching. Bulletin of the
Transilvania University of Braşov, Series VIII: Performing Arts. 2019;12(2):7-12. doi:10.31926/but.pa.2019.12.61.11.

2. Staring J. Frederick Matthias Alexander, Born 150 Years Ago, on January 20, 1869. A Fierce Comment Regarding Interpretations of Alexander's Texts by Alexander Technique Teachers. Case Studies Journal. 2018;7(12):107-108.

3. Davies J. Alexander Technique classes improve pain and performance factors in tertiary music students. Journal of Bodywork and Movement Therapies. 2020;24(1): 1-7. doi:10.1016/j.jbmt.2019.04.006.

4. Salonen BL. Tertiary music students' experiences of an occupational health course incorporating the body mapping approach: dissertation. Bloemfontein: Odeion School of Music of the Free State University; 2018.

5. Napier E. Fostering Freedom: A Holistic Comparison of Karen Tuttle's Ideas with Body Mapping and the Alexander Technique: dissertation. Ann Arbor: University of Michigan; 2019.

6. Baadjou VA, Wijsman SI, Ginsborg J, Guptill C, de Lisle R, Rennie-Salonen B. Health education literacy and accessibility for musicians: a global approach. Report from the Worldwide Universities Network project. Medical problems of performing artists. 2019;34(2):105-107. doi:10.21091/mppa.2019.2011.

7. Ajidahun AT, Myezwa H, Mudzi W, Wood W. Barriers and facilitators in implementing an exercise-based injury prevention program for string players. Work. 2019;64(3): 713-720. doi: 10.3233/WOR-193033.

8. Matei R, Broad S, Goldbart J, Ginsborg J. Health education for musicians. Frontiers in psychology. 2018:9: 1137-1146. doi:10.3389/fpsyg.2018.01137.

9. Schemmann H, Rensing N, Zalpour C. Musculoskeletal Assessments Used in Quantitatively Based Studies About Posture and Movement in High String Players. MPPA. 2019;33(1):56-71. doi: 10.21091/mppa.2018.1009.

10. Wolf E, Möller D, Ballenberger N, Morisse K, Zalpour C. Marker-Based Method for Analyzing the ThreeDimensional Upper Body Kinematics of Violinists and Violists. Med Probl Perform Art. 2019;34(4):179-190. doi: 10.21091/mppa.2019.4029.

11. Johnson D, Damian D, Tzanetakis G. Detecting Hand Posture in Piano Playing Using Depth Data. Computer Music Journal, 2020;43(1): 59-78. doi:10.1162/COMJ a 00500 .

12. Stanhope J. Physical performance and musculoskeletal disorders: Are musicians and sportspeople on a level playing field? Performance Enhancement \& Health. 2016;4(1-2): 18-26. doi:10.1016/j.peh.2015.11.004. 13. McCrary JM, Halaki M, Sorkin E, Ackermann BJ. Acute warm-up effects in submaximal athletes: An EMG 
study of skilled violinists. Med Sci Sports Exerc. 2016;48(2): 307-315. doi: 10.1249/MSS.0000000000000765.

14. Savvidou P, Stanek J. Playing-Related Pain and Associated Habits Among Students and Faculty at a Major University Music Program: A Study of Prevalence with Recommendations for Teachers. MTNA e-Journal. 2019;11(1): 2-12.

15. Ajidahun AT. Myezwa H, Mudzi W, Wood W. A scoping review of exercise intervention for playing-related musculoskeletal disorders (PRMDS) among musicians. Muziki. 2019; 16(1): 7-30. doi:10.1080/18125980.2019.1606675.

16. Akel BS, Aran OT, Öksüz Ç. The Effect of Stabilization Exercises on Playing Performance in Musicians With Joint Hyperlaxity. HAND. 2016;11(1): 137-139. doi:10.1177/1558944716660555jo.

17. Baadjou V, Verbunt J, van Eijsden-Besseling F, de Bie R, Girard O, Twisk J, Smeets R. Preventing musculoskeletal complaints in music students: a randomized controlled trial. Occupational Medicine. 2018;68(7): 469477. doi:10.1093/occmed/kqy105.

18. Lundborg B, Grooten WJ. Resistance training for professional string musicians: a prospective intervention study. Medical problems of performing artists. 2018; 33(2), 102-110. doi: 10.21091/mppa.2018.2017.

19. Hale G. Playing with Pain: Injury Prevention Strategies for Music Schools in the United States: diss. Washington: Washington American University; 2019.

20. Ting A, Rocker J. Evaluation and Treatment of Musicians from a Holistic Perspective. The Open Journal of Occupational Therapy. 2019;7(4):1-10. doi:10.15453/21686408.1581.

21. Stanhope J, Weinstein P. Should musicians play in pain? British Journal of Pain. 2020: 2049463720911399. doi: 10.1177/2049463720911399.

22. Fugazza L. Methods to support guitarists to recover from injuries and/or maintain health: dissertation. Kungl: Musikhögskolan; 2020.

\title{
OVERUSE INJURIES IN MUSICIANS. PART I: PREVENTION AND TREATMENT
}

\author{
Vladimir Berezutsky, Maryna Berezutska
}

Mail for correspondence: Berezut@ua.fm

Summary: Overuse injuries are encountered by 50-85\% of instrumental musicians and manifest themselves in tendovaginitis, bursitis and tunnel syndromes, leading to long-term temporary loss of ability to work (and in severe cases, to permanent disability). For Ukraine, the problem is of particular relevance for several reasons: first, there have been no studies of the professional diseases of musicians in the country in the last decade; second, there are a very large number of music schools in the country, but none of them teaches future musicians how to prevent occupational diseases; thirdly, there are no specialized medical centres for the treatment of professional pathology of musicians. The aim of the research was to analyze the latest achievements in diagnosing, treating and preventing stress injuries in musicians. The analysis was performed by studies published in 2016-2020 in journals indexed in the Scopus, WoS, Medline and PubMed scientific databases. It has been established that the effective prevention of stress injuries in musicians is possible only through a comprehensive approach involving the reorganization of musical education and medical support for the professional activity of instrumental musicians. For the formation of ergonomic performing techniques, as well as providing future musicians with knowledge and skills to maintain health in the context of their profession, it is necessary to introduce the appropriate discipline into the curriculum, the teaching of which should be conducted with the participation of specialists in physical rehabilitation and physical education. To ensure the effective treatment of professional injuries in musicians, it is necessary to create a specialized republican rehabilitation center, as well as expanding the training program for trauma surgeons and rehabilitologists at the postgraduate stage through thematic refresher courses.

Key words: playing-related musculoskeletal disorders overuse injuries in musicians, a repetitive strain injury, ergonomic performing technique

Information about author

Berezutsky Vladimir, MD, PhD, Assoc.

Prof. Department of Internal Medicine,

State Establishment Dnepropetrovsk

Medical Academy, Vernadsky av. 9,

Dnipro, Ukraine, 49000 e-mail:

Berezut@ua.fm https://orcid.org/0000-0002-0989-2960

Berezutska Maryna, Assoc. Prof.

Department of Folk Instruments $M$.
Glinka Dnepropetrovsk Academy of

Music; 49044, Dnipro, Livarna av., 10; e-mail: Bermarser@gmail.com https://orcid.org/0000-0002-5511-2195 


\title{
«ПЕРЕГРАНА РУКА» АБО СИНДРОМИ ПЕРЕНАПРУГИ У МУЗИКАНТІВ. ЧАСТИНА І: ПРОФІЛАКТИКА І ЛІКУВАННЯ
}

\author{
Березуиьький В. І., Березуцฺька М. С.
}

Пошта для листування: Berezut@ua.fm

Резюме Травми перенапруги втречаются у 50-85\% музикантів-інструменталістів і проявляються 6 тендовагінітах, бурситах $i$ тунельних синдромах, що веде до тривалої тимчасової втрати працездатності (а у важких випадках - до стійкої). Для Украйни проблема має особливу актуальність з кількох причин: по-перше, дослідження професійних захворювання музикантів в краӥні в останні десятиления не проводилися; по-друге, в крайні дуже велика кількість музичних навчальних закладів, але ні в одному з них майбутніх музиканов не навчають профілактиці професійних захворювань; по-трете, в країні немає спеціалізованих медичних иентрів для лікування професійної патології музикантів. Метою дослідження був аналіз останніх досягнень в діагностиці, лікуванні та профілактиці травм перенапруги у музикантів. Аналізувались дослідження, опубліковані в 2016-2020 рр. в журналах, що індексуються в наукометричних базах Scopus, WoS, MedLine і PubMed. Встановлено, що ефективна профілактика травм перенапруги у музикантів можлива лише при комплексному підході, який передбачає реорганізацію музичної освіти і медичного забезпечення професійної діяльності музикантів-інструменталістів. Для формування ергономічної виконавської техніки, а також забезпечення майбутніх музикантів знаннями $i$ навичками по збереженню здоров'я в умовах своєї професії, необхідне введення в навчальні плани відповідної дисиипліни, викладання якої повинно вестися за участю фахівиів з фізичної реабілітації та фізичної культури. Для забезпечення ефективного лікування професійних травм у музикантів необхідне створення спещіалізованого республіканського реабілітаційного иентру, а також розширення програми підготовки лікарів хірургів-травматологів та реабілітологів на етапі післядипломної освіти за рахунок тематичних курсів підвищення кваліфікаиії.

Ключові слова: професійні хвороби музикантів, травми перенапруги, «переграна рука», ергономічна виконавська техніка

\footnotetext{
Інформація про авторів

Березуцький Володимир Іванович, к. мед. н., доцю кафедри пропедевтики внутрішньої медицини ГУ Дніпропетровська медична академія, вул. В. Вернадського, 9,
}

м. Дніпро Україна, 49044 e-mail: Berezut@ua.fm https://orcid.org/0000-0002-0989-2960 Березуцька Марина Сергївна, доц. кафедри народних інструментів
Дніпропетровської академії музики ім. М. Глінки, вул. Ливарна, 10, Дніпро, Україна, 49044 e-mail: Bermarser@gmail.com https://orcid.org/0000-0002-5511-2195

Conflicts of interest: author has no conflict of interest to declare.

Конфлікт інтересів: відсутній.

Конфликт интересов: отсутствует. 


\title{
ОСОБЛИВОСТІ СОМАТОПСИХІЧНИХ ПРОЯВІВ В ОНКОЛОГІЇ НА РІЗНИХ ЕТАПАХ ПРОТИПУХЛИННОГО ЛІКУВАННЯ (ОГЛЯДОВА СТАТТЯ)
}

\author{
Кирилова О. О., Кирилова Є. І., Вострокнутов І. Л.
}

Пошта для листування: Kirillovalena0908@gmail.com

\begin{abstract}
Резюме. Багато тисячоліть перед людством виникають питання взаємовідношення психіки та тіла при онкології, сучасні дослідники вказують на те, щзо психіка грає важливу роль в патогенезі раку, однак досліджень в області онкопсихологї в України мало. Метою даної роботи був аналіз особливостей соматопсихічних проявів у онкохворих.У якості матеріалів та методів використовувалися: теоретичний аналіз і узагальнення даних наукової літератури з проблеми соматопсихічних проявів у онкохворих. В процесі протипухлинного лікування пацієнт проходить етапи медичної допомоги, які характеризуються особливостями переживання психікою стресових факторів $i$ характерними психосоматоформними реакціями. На амбулаторному етапі, у онкохворих спостерігаються підвищення рівня реактивної тривоги, фобї, порушення циклу сну, наростання емоційного стресу. Превалюють тривожно-депрессивний $i$ астенічний синдроми.На етапі стаціонарного лікування наростає частота обсесивно-фобічних і апатичних розладів. У передопераційний період збільшується інтенсивність тривоги і страху. При отриманні променевої або поліхіміотерапії, спостерігаються порушення вищих психічних функиій. На етапі виписки проявляються ознаки астено-іпохондричного розладу. Страх рецидиву раку є найбільш частою проблемою на етапі ремісії. На етапі перебування в хоспісі актуалізується страх смерті. Висновки. Встановлено, щчо причинами соматопсихічних розладів онкохворих є: психічна реакція на стрес (звістка про діагноз, операція), вплив пухлинного процесу на психіку хворого та вплив процесу протипухлинної терапї. У більшості пацієнтів розвиваються виражені невротичні, пов'язані зі стресом, $і$ соматоформні розлади, переважно у вигляді депресивного синдрому різних варіантів і ступеня вираженості, нерідко іпохондричні (канцерофобічні), астенічні реакиї та стани.
\end{abstract}

Ключові слова: рак, соматопсихічні прояви при онкології, соматоформні розлади, нозогенії

Інформація про авторів

Кирилова Олена Олександрівна, к. псих. наук, старш. наук. співроб. відділу радіології групи променевої патології ДУ «Інститут медичної радіології та онкології Національної академії медичних наук України імені С.П. Григорє'ва», вул Пушкінська, 82, м. Харків, Україна, 61024 e-mail: Kirillovalena0908@gmail.com https://orcid.org/0000-0002-3508-0405

Кирилова Свгенія Ігорівна, студентка 4-го курсу медичного факультету імені В.Н. Каразіна, майдан Свободи, 6, Харківського національного м. Харків, Україна, 61022

університету імені В. Н. Каразіна, майдан Свободи, 6, м. Харків, Україна, 61022
Вступ. Багато тисячоліть перед людством виникають питання взаємовідношення психіки і тіла при онкологічних захворюваннях. Ще давньоримський лікар Гален припускав, що причиною раку $\epsilon$ надлишок чорної жовчі i схильність до меланхолії, i вказував що у меланхоліків ризик розвитку онкології набагато вище, ніж у людей 3 іншими типами темпераменту . Пізніше, в XVII-XIX ст. появу онкології у пацієнта лікарі стали пов'язувати зі страхами і переживанням важкого горя, сильним стресом, депресією, незадоволеними амбіціями, частими нападами люті. На початку XX століття лікування онкологічних захворювань послідовно розвивалося i проходило через стадії застосування хірургії, променевої терапії, азотистого іприту, паралельно також розвивалися і психосоматичні концепції. Так в 1950 році
A.Sutherland став першим психіатром, який працював в онкологічному стаціонарі Меморіального онкологічного центру СлоанаКеттерінг в Нью-Йорку. В Європі R.Feigenberg $(1970$ р) починав роботу в Королівському госпіталі Стокгольму, S.Greer (1971) 3 Королівського марсденского шпиталю Лондона і F. VanDam (1977 p) заснували групу вивчення якості життя в онкології (EORTC Quality of Life Study Group). У США J.Holland (1977 p.) розширила дослідження в Меморіальному центрі Слоана-Кеттерінг; A.Weisman (1978 р.) почав дослідження термінальних стадій раку в рамках спеціального проекту (Омега) в Бостоні. Підставою для більшості з цих досліджень було загальносвітове обговорення, чи варто онкологічним хворим говорити правду про їх стан 
і чи потребують ці хворі супроводу психіатра або психолога [1].

Сучасні дослідники вказують на те, що психіка відіграє важливу роль в патогенезі раку, проте предметна область онкопсихології містить в собі багато «білих плям». Емпіричні дослідження, що описують вплив пухлинного процесу на психіку пацієнта, нерідко містять суперечливі дані [2].

На даний момент психологічний супровід онкологічних хворих є обов'язковим, як на етапі діагностики, так і в процесі лікування [3, 4]. Але без чіткого уявлення про особливості соматопсихічних проявів у онкологічних хворих на різних стадіях пухлинного процесу і різних етапах протипухлинного лікування, неможлива повноцінна організація медико-психологічного супроводу онкохворих.

Проте, не дивлячись на актуальність вищевикладеного, у вітчизняному науковому просторі та реальній клінічній практиці за останні роки відсутні комплексні системні дослідження 3 питань вивчення особливостей розвитку соматопсихічних реакцій у онкологічних хворих на різних етапах комплексного протипухлинного лікування. Державна установа «Інститут медичної радіології та онкології ім. С.П.Григор'єва НАМН України» $є$ провідною установою в галузі медичної радіології та онкології, яка не тільки надає клінічну допомогу онкохворим, але й займається науковим напрямком розвитку онкології та зокрема онкопсихології. В рамках науково-дослідної роботи (НДР) «Закономірності формування індивідуальних комплексних регуляторних порушень у онкохворих при комбінованому лікуванні» (НАМН.01.15) проводено аналіз інтенсивності втоми, порушень когнітивних функцій , емоційного стану та сну у 55 хворих жінок на рак тіла матки I-II ст. на різних етапах протипухлинного лікування. Дослідження дозволило розробити та впровадити в роботу клініки Інституту програму медикопсихологічної корекції цієї кагорти онкохворих. На даний час заплановано до виконання у 20212023 р. нову НДР «Розроблення алгоритму психологічного супроводу хворих на колоректальний рак (КРР) на різних етапах лікування» (НАМН.01.20), де буде отримано нові дані щодо невротичних та соматопсихічних станів у хворих на КРР на різних етапах комплексного протипухлинного лікування, та вперше буде проведено аналіз взаємозв'язків між рівнем стрес-гормонів та психологічними адаптаційними можливостями цих пацієнтів. Вивчення цих питань та впровадження результатів в клінічну практику надасть можливість поліпшити якість життя онкохворих в Україні.

Мета дослідження - проаналізувати особливості соматопсихічних проявів у хворих 3 онкологією.

Матеріали i методи дослідження: теоретичний аналіз і узагальнення даних сучасної наукової літератури з проблеми соматопсихічних проявів у онкологічних хворих.

Результати дослідження. Під час протипухлинного лікування пацієнт проходить кілька етапів медичної допомоги та супроводу, кожен 3 яких характеризується своїми особливостями переживання психікою стресових факторів і характерними психосоматоформними реакціями.

На початковому діагностичному етапі пацієнт стикається 3 найпотужнішим стресовим чинником - діагнозом. Онкологічне захворювання, в таких випадках нерідко розглядається хворими не тільки як фізична патологія, а й як емоційна катастрофа, що порушує функціонування людини як особистості. Дослідження в клінічній психології свідчать про переважання показників психологічного емоційного стресу [5]. Стрес полягає в загрозі майбутньої важкої операції, можливої втрати важливого органу або зміни функціонування тіла, перспективи втрати сім'ї або соціального статусу, перспективи дорогого тривалого важкого лікування, перспективи тривалого больового синдрому, невизначеності прогнозу виживання. У більшості хворих на цьому етапі спостерігається підвищення рівня реактивної тривоги та занепокоєння, поява обсесивно-фобічної симптоматики, порушення циклу сну, i як наслідок - виснаження нервової та імунної систем, зниження адаптивних можливостей [6]. Особливо показники стресу переважають у хворих 3 мінімальним рівнем соціальної підтримки [7].

Високий рівень реактивної (ситуативної) тривоги знаходить природне пояснення в наявності вираженої психічної реакції хворих на 
своє захворювання, на ситуацію онкологічного стаціонару, актуалізації страхів перед запланованою операцією та за власне майбутнє. Але якщо у індивіда преморбідні особливості характеризувалися високим рівнем особистісної тривоги, слабким типом нервової системи, визначеними характерологічними комплексами (такими як істероїдність, іпохондрія, шизоїдність та ін.) або в анамнезі були психічні захворювання, то в цій ситуації існує висока ймовірність розвитку клінічної психосимптоматики. Жінки за своєю природою більш емоційні, ніж чоловіки, тому в літературі підтверджується більш часте виникнення афективних розладів різного типу i ступеню вираженості у жінок з онкологічними захворюваннями репродуктивної системи [8].

Вивченню ролі психогенного чинника в онкогенезі присвячено багато робіт і накопичено безліч фактів, що відносяться до їх дослідження. До етапу хірургічного втручання була вивчена клінічна психосимптоматика жінок 3 раком молочної залози (РM3). Найчастіше спостерігалися такі прояви, як: тривожнодепресивні реакції $(60,6 \%)$, змішаний розлад емоцій і поведінки (6,2\%), тривожно-фобічні стани $(5,2 \%)$, наявність суїцидальних думок пасивного характеру (14,3 \%). Як видно, основним синдромом на цьому етапі $\epsilon$ тривожнодепресивний [9].

На цьому етапі в ході експериментальнопсихологічного обстеження у таких жінок виявлені: прояви алекситимії, низький рівень психологічної стійкості до стресу, наявність ознак дезадаптації, труднощі міжособистісного спілкування, найбільш характерний ергопатичний тип ставлення до хвороби $[10,11]$.

Було виявлено, що високий показник алекситимії у хворих з РМЗ є психологічним предикатом виникнення психосоматичних розладів. Встановлено, що хворі з алекситимією схильні до розвитку іпохондричних і соматичних розладів [12].

Встановлено, що на амбулаторному етапі превалюють гіпернозогнозичні реакції, у половини хворих виникає тривожно-депресивний синдром 3 типовими проявами загального занепокоєння, вираженої тривоги, відчугтям безнадійності, безперспективності існування, думки про неминучу швидку і болісну смерть. Ці симптоми нерідко доповнюються вираженими іпохондричними розладами. На тлі стійкої тривоги спостерігається фіксація уваги на самопочутті, особливо на тілесних відчуттях. Хворі весь час шукають і «знаходять» особливі «несправності» організму, зазвичай посилаючись при цьому на невиразні та невизначені відчуття, які ними інтерпретуються, як швидке поширення пухлини по всьому тілу [3, 13].

Інший варіант реакції пацієнтів на амбулаторному етапі характеризується переважанням астенічного розладу. Ознаки депресивного настрою (пригніченість, думки про безнадійність свого стану, приреченості) поєднуються 3 підвищеною виснаженістю непереносимість фізичних i психічних навантажень, лабільність настрою $з$ підвищеною сльозливістю. Для таких пацієнтів типовими $є$ скарги на стійкі головні болі, відчуття розбитості, втоми, безсоння або, навпаки, сонливість. У деяких випадках клінічна картина доповнюється вираженими ознаками дисфоричного афекту зі злісним настроєм. Хворі стають похмурими, дратівливими, іноді без найменшого приводу спостерігаються гострі спалахи злості, які можуть супроводжуватися агресією, що спрямована на медичний персонал $[14,15]$.

Для пацієнтів 3 гіпонозогнозичним типом реакції характерно неохоче i нерегулярне відвідування поліклініки. Вони часто не доводять до кінця перше обстеження, негативно реагують на пропозиції стаціонарного обстеження i лікування. Ця реакція може виражатися в патологічному спокої, пасивності, фантазуванні про своє соматичне благополуччя $[16,17]$.

На стаціонарному етапі протипухлинного лікування (при отриманні хіміотерапії та променевого лікування), розподіл психогеній за синдромальною структурою приблизно такий, як і на діагностичному етапі. Однак, інтенсивність переживань хворого помітно зменшується. Цей феномен пояснюється формуванням первинної адаптації особистості до стресової ситуації та включенням іiї в діяльність, яка спрямована на протидію раку. Перші дні в стаціонарі - складні (первинна адаптація, відірваність від домашніх умов). Хворих, які поступають в стаціонар вперше, часто травмують бесіди 3 тими, хто потрапляє в стаціонар повторно, особливо 3 термінальними хворими. Це може викликати несподівану відмову пацієнта від лікування i вимогу негайної виписки. Зміст переживань хворих зводиться до постійної тривоги щодо 
операції та ії наслідків. Розвиваються обсесивнофобічні та апатичні розлади $[14,18]$.

У передопераційний період знову відзначається різке підвищення інтенсивності психогенних переживань. При отриманні звістки про термін операції у деяких хворих виникає до неї різко негативне ставлення, з'являється думка про відмову від оперативного втручання. Ці переживання нерідко виникають після контактів 3 уже прооперованими хворими, у яких залишилися негативні наслідки оперативного втручання. Головним переживанням хворих $\epsilon$ безпосередня загроза загибелі під час операції. Відносно малопомітні емоції тривоги і страху можуть раптово проявитися у хворих безпосередньо перед операцією і можуть бути причиною різкого підйому або падіння артеріального тиску, нападів стенокардії. Частота параноїдальних розладів на передопераційному етапі помітно збільшується, що може бути небезпечним із-за проявів аутоагресії та виникнення суїцидальних спроб $[17,19]$.

При вивченні стану жінок 3 РМЗ було встановлено, що до 10-14 дня після операції відзначалося істотне зниження показників тривоги і проявів депресивної симптоматики, зменшувались загальна пригніченість та дратівливість, припинилися розлади сну і зникали суїцидальні думки. А до 3-4 тижня у більшості пацієнток практично нівелювалися тривожнодепресивні, фобічні, обсесивні або панічні розлади. Зменшення психопатологічних розладів у хворих на РМЗ підтверджувалося як клінічно (за кортизол-інсуліновим коефіцієнтом напруги), так i експериментально-психологічними методами. Ця позитивна динаміка була характерна для жінок, яким була проведена мастектомія 3 одночасною реконструкцією молочної залози, або якщо операція була органозберігаючою (квадрантектомія). Хворі, яким була проведена радикальна мастектомія, на етапі хірургічного втручання були сильно соціально дезадаптовані, відчували стан депривації, були занурені в емоційні переживання, пов'язані 3 факторами видимого дефекту та втратою жіночої ідентичності [9].

На першому місці за частотою виникнення в післяопераційному періоді реєструється астеноіпохондричний синдром. Його частота визначається фактом загального спаду психічної напруги після тривалої стресової ситуації i перебільшеними

побоюваннями

перед

ускладненнями, невпевненістю в тому, що налагодяться порушені оперативним втручанням функції організму. Другим за частотою $\epsilon$ апатичний синдром. У таких хворих достовірно частіше фіксуються післяопераційні ускладнення (в'яле загоєння ран, атонія кишківника, сечового міхура). Дисфоричний синдром головним чином проявляється в постійному невдоволенні хворих результатами операції, скаргами на недостатню увагу i поганий догляд 3 боку медичного персоналу. Характер оперативного втручання, інвалідизація викликають у таких хворих різко негативну реакцію, вони скаржаться, що дали згоду на проведення операції, заявляють, що були введені лікарями в оману щодо особливостей лікування [15].

Як відзначають онкопсихологи, у пацієнтів, які знаходяться на етапі тривалого лікування в онкологічному стаціонарі, при проведенні променевої терапії, спостерігаються порушення вищих психічних функцій: загальне порушення активності і уваги, зниження пам'яті, порушення когнітивних функцій (розумових, пізнавальних), порушення рухових функцій, емоційні порушення (тривога і страх загрози рецидиву, прояви проблем соціальної адаптації) $[6,18]$.

При наявності у хворого на цьому етапі хронічного больового синдрому, відзначається різке зниження якості життя i підвищення ймовірності появи нервово-психічних розладів [20].

У 75,7 \% пацієнтів на цьому етапі при обстеженні виявлено тривожно-депресивні, депресивні, субдепресивні, іпохондричні (канцерофобічні), астенічні реакції і стани, які відповідно до МКX-10 кваліфіковані як невротичні, пов'язані зі стресом і соматоформні розлади (F40-F48) [21].

На етапі виписки зі стаціонару спостерігається найбільша частота розвитку психологічного ейфоричного стану, але також відзначається помітна іпохондрична налаштованість хворих. В цьому періоді астено-іпохондричні розлади займають перше місце, до них приєднуються тривожно-іпохондричні, тривожно-депресивні, апатичні i обсесивно-фобічні переживання. Травмуючими $є$ думки про часткове одужання, розуміння, що радикальних засобів лікування від пухлини немає. Особливо патогенним $\epsilon$ прийняття на облік в онкологічний диспансер та 
повідомлення лікаря про подальші курси хіміотерапії [15].

Після виписки зі стаціонару провідною виступає тенденція до самоізоляції. Хворі підкреслюють відчуття своєї самотності, ізольованості, нарікають на те, що оточуючі, навіть найрідніші люди не розуміють їх. Нерозуміння близьких спрямовує хворих до спілкування 3 «товаришами по нещастю». Створюються замкнуті групи онкологічних хворих, члени яких підтримують тісний зв'язок у соціальних мережах, підтримуючи один одного.

Досліджуючи пацієнток 3 РМ3 було встановлено, що на етапі після виписки зі стаціонару, після хірургічного втручання пацієнтки відзначають погіршення емоційного стану у вигляді наростання почуття тривоги і депресії. Дана тенденція пов'язана 3 тим, що пацієнтки виявляються «один на один» зі своїм захворюванням, а до діагнозу, який вже сам по собі $\epsilon$ найпотужнішим стресовим чинником, додаються сімейні та професійні проблеми [22].

$\begin{array}{ccr}\text { Відзначається } & \text { наявність } & \text { симптомів } \\ \text { посттравматичного } & \text { стресового } & \text { розладу }\end{array}$
проявлених у формі інвазивних переживань, «думок, що вторгаються», як спогадів про хірургічне та консервативне лікування, так і про можливості прогресування захворювання в майбутньому [23]. Страх прогресування захворювання $є$ одним 3 тих, що найчастіше зустрічається, серед проблем у онкологічних хворих на етапі ремісії [24].

У більшості пацієнтів на етапі перебування в хоспісі в тій чи іншій мірі виникає фобічна симптоматика, яка пов'язана 3 усвідомленням кінцівки буття i актуалізації «головного» екзистенціального страху - страху смерті $[25,26]$.

Висновки Проведений аналіз вітчизняних та закордонних публікацій дозволяє зробити висновок, що причинами соматопсихічних розладів онкохворих є: психічна реакція на стрес (звістка про онкологічне захворювання, операція), вплив пухлинного процесу на психіку хворого та вплив процесу протипухлинної терапії. Кожен етап комплексного лікування характеризується особливими психосоматоформними реакціями онкохворого. У більшості випадків розвиваються виражені невротичні, пов'язані зі стресом, і соматоформні розлади, переважно у вигляді депресивного синдрому різних варіантів і ступеня вираженості (тривожно-депресивний; астено-депресивний; тривожно-фобічний), нерідко іпохондричні (канцерофобічні), астенічні реакції та стани.

\section{Список літератури}

1. Levin T, Kissane WD. Психоонкология: состояние на 2006 г. (расширенный реферат). Consilium medicum. 2007;3:10-14.

2. Рогозинская ВГ. Психосоматические и соматопсихические соотношения в онкологии. Известия высших учебных заведений. Уральский регион. 2018;1:94-109.

3. Костина НИ, Кропачева ОС. Психологическая помощь пациентам с онкопатологией и их близким на этапе оказания стационарной помощи. Злокачественные опухоли. 2016; (41):59-63.

4. Семиглазова ТЮ, Ткаченко ГА, Чулкова ВА. Психологические аспекты лечения онкологических больных. Злокачественные опухоли. 2016; (41):54-58.

5. Rhonda L Johnson, Michael A Gold, Karen F Wyche. Distress in women with gynecologic cancer. Psychooncology. 2010 Jun; 19(6):665-8. DOI: 10.1002/pon.1589

6. Бяй ЕГ. Применение интегративного подхода в рамках психологической поддержки детей и их родителей, находящихся на лечении в онкологическом стационаре (РОНЦ ИМЕНИ Н.Н.БЛОХИНА). Материалы V Всероссийского съезда онкопсихологов; 2013 нояб. 14-16; Москва: АНО «Проект СО-действие»; 2013, c. 11-17.

7. Шмекевич АБ, Водолагин АВ, Балакина ДД. Междисциплинарные аспекты реабилитации онкологических больных в нетерминальной ситуации болезни. Саратовский научно-медицинский журнал. 2017 дек. 14; 4(13): 806-808.

8. Березанцев АЮ, Монасыпова ЛИ, Стражев СВ. Клинико-психологические аспекты реабилитации женщин, страдающих раком молочной железы. Опухоли женской репродуктивной системы. 2012 янв.; (1):8-12.

9. Бугайцов СГ. Рак молочної залози реабілітація, корекція психосоматичних розладів в процесі комплексного лікування [автореферат в Internet]. Київ: Інститут онкології АМН України; 2003. [цитовано 14.01.07] Доступно на: http://www.disslib.org/rak-molochnoyi-zalozy-reabilitatsiakorektsia-psykhosomatychnykh-rozladiv-v-protsesi.html

10. Сивохина ТА, Храмкова ОВ. Особенности психологической коррекции эмоционального состояния больных раком молочной железы с помощью сеансов релаксации. Материалы VI Всероссийского съезда онкопсихологов; 2014 нояб. 13-15; Москва; Москва: АНО «Проект СО-действие»; 2014, с. 67-69.

11. Лапочкина НП, Блинова КА, Борута СА, Анисимов ВМ, Козлов ВА, Чистяков АВ, Круглова МЛ, Калачикова ЕВ. Психо-вегетативные особенности женщин с заболеваниями молочных желез. Материалы VI Всероссийского съезда онкопсихологов; 2014 нояб. 13-15; Москва; Москва: АНО «Проект СО-действие»; 2014 , c. $48-50$ 
Actual problems of modern medicine. Issue 6, 2020

12. Лапочкина НП, Блинова КА, Борута СА, Анисимов ВМ, Козлов ВА, Чистяков АВ, Круглова МЛ, Калачикова ЕВ Психологические особенности женщин с заболеваниями молочных желез. Материалы VI Всероссийского съезда онкопсихологов; 2014 нояб. 1315; Москва; Москва: АНО «Проект СО-действие»; 2014, c. $50-53$

13. Гнездилов АВ. Психические отклонения у онкологических больных. Практ. онкология. 2001 март. 1(5): 5-13.

14. Бажин ЕФ, Гнездилов АВ. Психогенные реакции у онкологических больных. Метод. рекомендации. Санкт-Петербург: Ленингр. науч.исслед. психоневрол. ин-т; 1983. 34 с.

15. Малкина-Пых ИГ. Психосоматика. Справочник практического психолога. Москва: Эксмо; 2010. 1024 с.

16. Ананьева ЕП. Роль клинического психолога на амбулаторном этапе лечения онкологических пациентов. Материалы III Всероссийского съезда онкопсихологов; 2011 авг. 26-27; Москва; Москва: АНО «Проект СО-действие»; 2011, с.8-12

17. Зотов ПБ. Суицидальные действия больных злокачественными новообразованиями. Сиб. вестн. психиатрии и наркологии. 2005; 2: 99-101.

18. Захарова МЛ, Иванов ПИ. Специфика состояния пациентов с метастатическим поражением головного мозга, поступивших на радиохирургическое лечение на аппарате Гамма-нож. Материалы X Всероссийского съезда онкопсихологов; 2018 нояб. 8-10; Москва; Москва: «Ясное утро»; 2018, с.23-25.

19. Зотов ПБ. Хроническая боль среди факторов суицидальной активности онкологических больных. Вестн. РОНЦ им. Н. Н. Блохина РАМН. 2004; 3: 81-83.

20. Комкова ЕП, Магарилл ЮА. Антидепрессанты в преодолении болевого синдрома у онкологических больных. Материалы V Всероссийского съезда онкопсихологов; 2013 нояб. 14-16; Москва: АНО «Проект СО-действие»; 2013, с.34-36.

21. Котюкова АЮ. Психологический компонент программы по реабилитации пациенток после хирургического лечения рака молочной железы. Материалы V Всероссийского съезда онкопсихологов; 2013 нояб. 14-16; Москва: АНО «Проект СО-действие»; 2013, C.36-38.

22. Caryn Mei Hsien Chan, Chong Guan Ng, Nur Aishah Taib, Lei Hum Wee, Edward Krupat, Fremonta Meyer. Course and predictors of post-traumatic stress disorder in a cohort of psychologically distressed patients with cancer: a 4-year follow-up study. Cancer. 2018 Jan 15; 124(2): 406-416.

23. Генс ГП, Олейникова ИН, Коробкова ЛИ. Посттравматическое стрессовое расстройство у больных раком яичников. Медицинский совет. 2014; 2: 93-96.

24. Сирота НА, Московченко ДВ. Страх прогрессирования заболевания и совладающее поведение у пациенток, страдающих раком яичников. Клиническая и медицинская психология: исследования, обучение, практика: электрон. науч. журн. [Интернет]. 2014 [цитировано 10.09.2020 г.]; 3 (5): 1-3. Доступно на: URL: http://medpsy.ru/climp
25. Леоненкова С., Вагайцева МВ. Особенности работы с умирающими онкологическими пациентами и их близкими. Материалы VI Всероссийского съезда онкопсихологов; 2014 нояб. 13-15; Москва; Москва: АНО «Проект СО-действие»; 2014, с. 53-55.

26. Тарасюк ВС, Кучанская ГБ. Паліативнохоспісна допомога. Київ: ВСВ «Медицина»; 2015. 328 с.

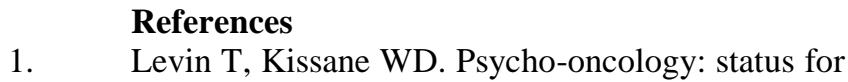
2006 (extended abstract). Consilium medicum. 2007; 3:1014.

2. Rogozinskaya VG. Psychosomatic and somatopsychic relationships in oncology. Proceedings of higher educational institutions. Ural region. 2018; 1: 94-109. 3. Kostin NI, Kropacheva OS. Psychological support to patients with oncopathology and their relatives at the stage of inpatient care. Malignant tumors. 2016; (41): 59-63.

4. Semiglazova TYU, Tkachenko GA, Chulkova VA. Psychological aspects of the treatment of cancer patients. Malignant tumors. 2016; (41): 54-58.

5. Rhonda L Johnson, Michael A Gold, Karen F Wyche. Distress in women with gynecologic cancer. Psychooncology. 2010 Jun; 19(6):665-8. doi: 10.1002/pon.1589.

6. Byay EG. Application of an integrative approach within the framework of psychological support for children and their parents being treated in an oncological hospital (N.N.Blokhin Russian Cancer Research Center). Materials of the V All-Russian Congress of Oncopsychologists; 2013 nov. 14-16; Moscow: ANO Project SO-Action; 2013, p. 1117 .

7. Shmekevich AB, Vodolagin AV, Balakina DD. Interdisciplinary aspects of rehabilitation of cancer patients in a nonterminal disease situation. Saratov Journal of Medical Scientific Research. 2017 dec. 14; 4 (13): 806-808. 8. Berezantsev AU, Monasypova LI, Strazhev SV. Clinical and psychological aspects of rehabilitation of women suffering from breast cancer. Tumors of the female reproductive system. 2012 Jan; (1): 8-12.

9. Bugaytsov SG. Breast cancer - rehabilitation, correction of psychosomatic disorders in the process of complex treatment [author's abstract in the Internet]. Kiev: Institute of Oncology of the Academy of Medical Sciences of Ukraine; 2003. [quoted from 14.01.07] Available from: http://www.disslib.org/rak-molochnoyi-zalozy-reabilitatsiakorektsia-psykhosomatychnykh-rozladiv-v-protsesi.html

10. Sivokhina TA, Khramkova OV. Features of the psychological correction of the emotional state of breast cancer patients using relaxation sessions. Materials of the VI All-Russian Congress of Oncological Psychologists; 2014 nov. 13-15; Moscow; Moscow: ANO Project SO-Action; 2014, p. 67-69.

11. Lapochkina NP, Blinova KA, Boruta SA, Anisimov VM, Kozlov VA, Chistyakov AV, Kruglova ML, Kalachikova EV. Psycho-vegetative features of women with breast diseases. Materials of the VI All-Russian Congress of Oncological Psychologists; 2014 nov. 13-15; Moscow; Moscow: ANO Project SO-Action; 2014, p. 48-50.

12. Lapochkina NP, Blinova KA, Boruta SA, Anisimov VM, Kozlov VA, Chistyakov AV, Kruglova ML, Kalachikova EV. Psycho-vegetative features of women with 
breast diseases. Materials of the VI All-Russian Congress of Oncological Psychologists; 2014 nov. 13-15; Moscow; Moscow: ANO Project SO-Action; 2014, p.50-53.

13. Gnezdilov AV. Mental disorders in cancer patients. Pract. oncology. 2001 March. 1 (5): 5-13.

14. Bazhin EF, Gnezdilov AV. Psychogenic reactions in cancer patients. Method. recommendations. St. Petersburg: Leningrad. scientific research psychoneurol. in$\mathrm{t} ; 1983.34 \mathrm{p}$.

15. Malkina-Pykh IG. Psychosomatics. A practical psychologist's reference book. Moscow: Eksmo. 2010. 1024 p.

16. Ananyeva EP. The role of a clinical psychologist in the outpatient treatment of cancer patients. Materials of the III All-Russian Congress of Oncological Psychologists; 2011 Aug 26-27; Moscow; Moscow: ANO Project SOAction; 2011, pp. 8-12.

17. Zotov PB. Suicidal actions in cancer patients. Sib. vestn. psychiatry and narcology. 2005; 2: 99-101.

18. Zakharova ML, Ivanov PI. Specificity of the condition of patients with metastatic brain lesions admitted to radiosurgical treatment using the Gamma Knife apparatus. Materials of the $\mathrm{X}$ All-Russian Congress of Oncopsychologists; 2018 nov. 8-10; Moscow; Moscow: "Clear Morning"; 2018, pp. 23-25.

19. Zotov PB. Chronic pain among the factors of suicidal activity in cancer patients. Vestn. RCRC. N.N.Blokhin RAMS. 2004; 3: 81-83.

20. Komkova EP, Magarill YA. Antidepressants in overcoming pain in cancer patients. Materials of the V All-
Russian Congress of Oncopsychologists; 2013 nov. 14-16; Moscow: ANO Project SO-Action; 2013, p. 34-36.

21. Kotyukova A.Yu. The psychological component of the program for the reabilitation of patients after surgical treatment of breast cancer. Materials of the V All-Russian Congress of Oncopsychologists; 2013 nov. 14-16; Moscow: ANO Project SO-Action; 2013, p. 36-38.

22. Caryn Mei Hsien Chan, Chong Guan Ng, Nur Aishah Taib, Lei Hum Wee,

Edward Krupat, Fremonta Meyer. Course and predictors of post-traumatic stress disorder in a cohort of psychologically distressed patients with cancer: a 4-year follow-up study. Cancer. 2018 Jan 15; 124(2): 406-416.

23. Gens GP, Oleinikova IN, Korobkova LI. Posttraumatic stress disorder in ovarian cancer patients. Medical advice. 2014; 2: 93-96.

24. Syrota NA, Moskovchenko DV. Fear of disease progression and coping behavior in patients with ovarian cancer. Clinical and medical psychology: research, teaching, practice: electron. scientific. mag. [The Internet]. 2014 [cited 09/10/2020]; 3 (5): 1-3. Available from: URL: http://medpsy.ru/climp

25. Leonenkova S., Vagaytseva MV. Features of working with dying cancer patients and their relatives. Materials of the VI All-Russian Congress of Oncological Psychologists; 2014 nov. 13-15; Moscow; Moscow: ANO Project SO-Action; 2014, p. 53-55

26. Tarasyuk VS, Kuchanskaya GB. Palliative-hospice care. Kyiv: BCB "Medicine"; 2015.328 p.

\title{
FEATURES OF SOMATOPSYCHIC MANIFESTATIONS IN ONCOLOGY AT DIFFERENT STAGES OF ANTI-CANCER THERAPY (REVIEW ARTICLE)
}

\author{
Kyrylova Olena, Kyrylova Yevheniia, Vostroknutov Ivan
}

Mail for correspondence: Kirillovalena0908@gmail.com

\begin{abstract}
Summary. People have got a lot of questions about the relationships between mind and body in oncology for many years. Modern researchers point out to the important role of mind in the pathogenesis of cancer, but there are not enough researches in the oncopsychology in Ukraine. It is impossible to organize the support of cancer patients without studying the features of somatopsychic manifestations at different stages of cancer and stages of treatment. The purpose of this work was to analize the features of somatopsychic manifestations in cancer patients. Theoretical analysis and generalization of data from the scientific literature on the problem of somatopsychic manifestations in cancer patients were used as materials and methods. As a result, the patient undergoes stages of medical care, in the process of anti-cancer treatment, which are characterized by the features of the mind experience of stress factors and specific psychosomatic reactions. Cancer patients have an increased level of anxiety, phobic symptoms, sleep disorders, increased indicators of distress in the outpatient phase. Anxiety-depressive and asthenic syndromes are prevailed. The frequency of obsessive-phobic and apathetic disorders increases at the stage of hospital treatment. The intensity of anxiety and fear increases before surgery. Higher mental functions are impaired during radiation therapy or chemotherapy. The signs of asthenohypochondriac disorder appears at the stage of hospital discharge. Symptoms of post-traumatic stress disorder and fear of cancer progression are the most common problems in remission. The phobic symptoms associated with fear of death appears during the stay in the hospice. Conclusions. The analysis of native and foreign publications allows us to conclude that the causes of somatopsychic disorders in cancer patients are: mental reaction to stress (news about an oncological disease, surgery), the effect of the tumor process on the patient's mind and the effect cancer therapy. Each stage of complex treatment is characterized by special
\end{abstract}


Actual problems of modern medicine. Issue 6, 2020

psychosomatoform reactions of a cancer patient. In most cases, severe neurotic, stress-related and somatoform disorders develop, mainly in the form of a depressive syndrome of different variants and severity (anxiousdepressive; asthenic-depressive; anxious-phobic), often hypochondriacal (carcinophobia), asthenic reactions.

Key words: cancer, somatopsychic symptoms in cancer, somatoform disorders, psychogenic reactions

Information about author

Kyrylova Olena, $\mathrm{PhD}$ in Psychology, Senior Researcher Department of Radiology group of Radiation pathology, State Organization «Grigoriev Institute for Medical Radiology and Oncology of the National Academy of
Medical Sciences of Ukraine», Pushkinskaya str.82, Kharkiv, Ukraine, 61024

e-mail: Kirillovalena0908@gmail.com https://orcid.org/0000-0002-3508-0405

Kyrylova Yevheniia, 4th year student of School of Medicine V. N. Karazin Kharkiv
National University, 6, Svobody Sq., 61022, Kharkiv, Ukraine

Vostroknutov Ivan, 4th year student of School of Medicine V. N. Karazin Kharkiv National University, 6, Svobody Sq., 61022, Kharkiv, Ukraine

\title{
ОСОБЕННОСТИ СОМАТОПСИХИЧЕСКИХ ПРОЯВЛЕНИЙ В ОНКОЛОГИИ НА РАЗНЫХ ЭТАПАХ ПРОТИВООПУХОЛЕВОГО ЛЕЧЕНИЯ (ОБЗОРНАЯ СТАТЬЯ)
}

\author{
Кириллова Е. А., Кириллова Е. И., Вострокнутов И. Л.
}

Почта для переписки: Kirillovalena0908@gmail.com

Резюме. Многие тысячелетия перед человечеством возникают вопросы взаимоотношения психики и тела при онкологии, современные исследователи указывают на то, что психика играет важную роль в патогенезе рака, однако исследований в области онкопсихологии на Украине мало. Без знания особенностей соматопсихических проявлений у онкобольных на разных стадиях рака и этапах комплексного лечения, невозможна организация их сопровождения. Целью данной работь был анализ особенностей соматопсихических проявлений у онкобольных. В качестве материалов и методов использовались: теоретический анализ и обобщение данных научной литературы по проблеме соматопсихических проявлений у онкобольных. В результате были получены данные о том, что в процессе противоопухолевого лечения пациент проходит этапы медицинской помощи, характеризуюшиеся особенностями переживания психикой стрессовых факторов и характерными психосоматоформными реакциями. На амбулаторном этапе, у онкобольных наблюдаются повымение уровня реактивной тревоги, фобии, нарушение иикла сна/бодрствования, нарастание эмоционального стресса. Превалируют тревожно-депрессивный и астенический синдромы. На этапе стационарного лечения нарастает частота обсессивно-фобических и апатичных расстройств. В предоперачионный период увеличивается интенсивность тревоги и страхов. При получении лучевой или полихимиотерапии, наблюдаются нарушения высших психических функиий. На этапе выписки проявляются признаки астеноипохондрического расстройства. Симптомы посттравматического стрессового расстройства и страх прогрессирования рака являются наиболее частыли проблемами у паџиентов на этапе ремиссии. На этапе пребывания в хосписе актуализируется страх смерти.

Выводы. Проведенный анализ отечественных и зарубежных публикаций позволяет сделать вывод, что причинами соматопсихических расстройств онкобольных являются: психическая реакиия на стресс (известие об онкологическом заболевании, операџия), влияние опухолевого процесса на психику больного и влияние прочесса противоопухолевой терапии. Каждый этап комплексного лечения характеризуется особыми психосоматоформными реакциями онкобольного. В большинстве случаев развиваются выраженные невротические, связанные со стрессом, и соматоформные расстройства, преимущественно в виде депрессивного синдрома различных вариантов и степени выраженности (тревожно-депрессивный; астено-депрессивный; тревожно-фобический), нередко ипохондрические (канцерофобические), астенические реакции и состояния.

Ключевые слова: рак, соматопсихические проявления при раке, соматоформные расстройства, нозогении

\section{Информация об авторах}

Кириллова Елена Александровна, к. псих. наук, старш. науч. сотр., отделения радиологии группы лучевой патологии ГУ «Институт медицинской радиологии и онкологии имени С. П. Григорьева НАМН Украины», ул.Пушкинская, 82, г.Харьков, Украина, 61024 e-mail: Kirillovalena0908@gmail.com https://orcid.org/0000-0002-3508-0405

Кириллова Евгения Игоревна, студентка 4-го курса медицинского факультета Харьковского 
Актуальні проблеми сучасної медицини. Випуск 6, 2020

национального университета

им.В.Н.Каразина, пл. Свободы, 6, г.

Харьков, Украина, 61022
Вострокнутов Иван Леонидович, студент 4-го курса медицинского факультета Харьковского

национального университета им. В. Н. Каразина, пл. Свободы, 6, г. Харьков, Украина, 61022

Conflicts of interest: author has no conflict of interest to declare. Конфлікт інтересів: відсутній.

Конфликт интересов: отсутствует. 


\title{
РОЗВИТОК ТА БУДОВА СТРУКТУР СЕРЦЕВО-СУДИННОЇ СИСТЕМИ: ТЕОРЕТИЧНІ ТА ПРАКТИЧНІ АСПЕКТИ ВИВЧЕННЯ (ЧАСТИНА 1)
}

\author{
Проценко О. С., Шаповал О. В., Тесленко А. А., Ворона Д. А.
}

Пошта для листування: shapoval@karazin.ua

\begin{abstract}
Резюме. У статті висвітлено теоретичні та практичні аспекти вивчення розвитку та будови серцевосудинної системи (ССС). Хвороби серия та судин характеризуються високою частотою та смертністю, тому надання якісної та своєчасної кардіологічної допомоги населенню є одним з важливих завдань системи охорони здоров я. Необхідною умовою розуміння сутності морфологічних змін при патологічних процесах $\epsilon$ знання нормальної будови та розвитку структур ССС. Метою роботи було визначення теоретичних та практичних аспектів вивчення розвитку та будови структур ССС, щуо було проведено шляхом аналізу літературних джерел (частина 1 статті присвячена теоретичним аспектам, частина 2 - практичним). Проаналізовано друковані видання та інші джерела інформацї з анатомї, гістологї, цүитологї та ембріологї̈, які використовуються при вивченні розвитку та будови організму людини, зокрема, органів ССС. Окрім класичних джерел, проаналізований ряд сучасних навчальних посібників, в тому числі, анатомічні та гістологічні флеш-картки, атласи-розфарбовки, анатомічні 3D-атласи, Wеb-ресурси. Ембріогенез серия та судин розглянуті у більшості навчальних видань, існують також сучасні спеціальні видання з ембріології людини. Визначена важливість використання видань, які є посібниками для практичної діяльності фахівців у області кардіологї та кардіохірургії. Усі сучасні видання містять великі колекиіі рентгенівських, комп ютерних, магнітно-резонансних та фото гістологічних препаратів. Корисними є ресурси симуляційних центтрів, зокрема, сенсорні інтерактивні анатомічні столи зі спеціальним програмним забезпеченням. Програми, призначені для навчальної демонстрації різних ланок ССС людини у нормі та при патологї, $\epsilon$ доступними для смартфонів, планшетів та стаціонарних комп 'ютерів. Визначено, щзо для отримання якісної теоретичної підготовки при вивченні розвитку та будови серия та судин, важливим є використання клінічно орієнтованих навчальних видань. При розробці нових навчальних матеріалів перспективним є внесення до їх складу клінічних та експериментальних даних щзодо ССС.
\end{abstract}

Ключові слова: серцево-судинна система, ембріогенез, макроскопічна будова, мікроскопічна будова, теоретичні аспекти

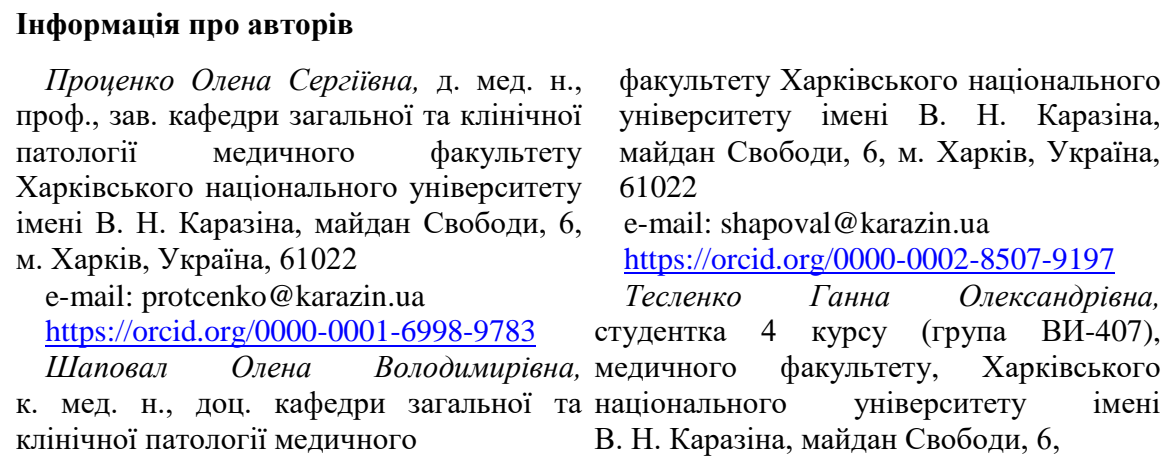

м. Харків, Україна, 61022

e-mail: teslenkoan7@gmail.com

Ворона Дарія Анатоліївна, студентка 4 курсу (група ВИ-405) медичного факультету, Харківський національний університет імені В. Н. Каразіна, медичний факультет, майдан Свободи, 6, м. Харків, Україна, 61022 e-mail: vorona.dariya05@gmail.com

\section{Вступ}

Серцево-судинні захворювання (СС3) - група хвороб серця та кровоносних судин, які $\epsilon$ основною причиною смерті в усьому світі. Щорічно від ССЗ помирає більше людей, ніж від будь-якої іншої хвороби. [1]. Важливою причиною дитячої захворюваності та смертності $\epsilon$ вроджені вади серця (BBC); їx росповсюдженість варіює від 19 до 75 на 1 тис. живонароджених [2]. ВВС займають друге місце за частотою серед причин смертності дітей першого року життя після інфекційних захворювань [3].

Смертність від ССЗ можливо знижати завдяки поєднанню заходів профілактики та контролю, а покращення показників наслідків СС3 вірогідно досягнути шляхом ранньої діагностики цих захворювань [1]. Профілактика СС3 та боротьба 3 ними неможливі без укріплення всіх ланок охорони здоров я $[4,5]$ Поліпшення медикодемографічної ситуації, підвищення доступності та якості медичної допомоги всім верствам 
населення $\epsilon$ пріоритетним завданням сучасної системи охорони здоров'я в Україні. Різні аспекти стану здоров'я населення у зв'язку з хворобами серцево-судинної системи, а також питання вдосконалення державної системи охорони здоров'я та системи надання кардіологічної допомоги населенню, є предметом багаторічних досліджень авторів [6].

При цьому існують основні вимоги стосовно теоретичних та практичних навичок спеціалістів, визначені організаційно-методологічні основи підготовки лікарів, які надають допомогу хворим з СС3, та тенденції розвитку кардіології та кардіохірургії $[4,5]$. У цьому контексті важливим $\epsilon$ визначення та використання якісних інструментів для отримання теоретичних знань щодо розвитку та будови структур серцевосудинної системи.

Мета роботи. Визначення теоретичних та практичних аспектів вивчення розвитку та будови структур серцево-судинної системи (у частині 1 статті розглянуто теоретичні аспекти, практичним аспектам присвячена частина 2).

Матеріали та методи дослідження. Теоретичні аспекти вивчення розвитку та будови структур серцево-судинної системи (ССC) визначалися шляхом аналізу літературних джерел.

Результати. Знання етапів ембріогенезу, нормальної макроскопічної та мікроскопічної будови структур ССС $€$ необхідною умовою розуміння сутності морфологічних змін за наявності розвитку патологічних процесів. Перед тим, як засвоїти теоретичну інформацію та одержати практичну підготовку 3 питань етіології, патогенезу, клініки, діагностики, лікування та профілактики захворювань ССС, лікар на етапах навчання отримує знання щодо нормального розвитку та макроскопічної i мікроскопічної будови структур серцевосудинної системи $[7,8]$.

Класичним навчальним виданням, призначеним для студентів вищих медичних закладів, а також таким, що пропонується як посібник для лікарів, $\epsilon$ всесвітньо відомий «Атлас анатомии человека» Р.Д.Синельникова [9]. Даний атлас багато разів перевидавався, його матеріали засновані на оригінальних дослідженнях, текст ілюстрований великою кількістю рисунків та фотографіями анатомічних препаратів. У розділі
«Учение о сосудах, или ангиология», окрім детальних ілюстрацій та опису будови серця та судин дорослої людини, наведено дані про розвиток та вікові особливості ССС. Схема «Стадії розвитку серця» демонструє загальний вигляд структур, 3 яких розвивається серце, 2 - 2,5 - ,3 - ,3,5 - та 5-тижневого зародка. Надана інформація щодо ембріональних джерел походження та етапів розвитку судин та серця, положення серця у ембріогенезі та після народження, також макроскопічні характеристики, дані про розміри та вагу серця у процесі росту дитини. Також у виданні наявні дані щодо кровопостачання плоду та ілюстрація «Артерії та вени доношеного плоду». Вищеназвана ілюстрація багато років цитується у чисельних анатомічних та гістологічних підручниках.

Високоякісними ілюстраціями відоме визнане у світі навчальне видання, яке протягом багатьох років перевидається на різних мовах- «Атлас анатомії людини» Френка Г. Неттера [10]. Ця книга належить до найвідоміших зібрань ілюстрацій анатомії людини в галузях медицини й охорони здоров'я. Акцент у даному посібнику зроблений на клінічному значенні анатомії, що надає можливість від самого початку вивчати будову тіла людини у тому ракурсі, який потрібен для розуміння топографії органів - їх голо-, скелето- та синтопії.

Атлас структурований не по системах органів, а по частинах тіла, тому інформація щодо ССС у даному виданні міститься у складі усіх розділів. Окрім знаменитих матеріалів Неттера, видання містить майже 100 кольорових ілюстрацій Карлоса А.Г. Мачадо, одного 3 провідних сучасних медичних ілюстраторів. Авторству Мачадо належать зображення «Атласу» в анатомічних проекціях, які набули клінічної значущості протягом останніх років і стали можливими завдяки поліпшеним методам анатомування та сучасної візуалізації. Видання також містить понад 50 ретельно відібраних рентгенівських зображень, що допомагають зіставити ідеалізовані анатомічні ілюстрації 3 живою анатомією, якою іiі бачать у щоденній практиці. Цікавим є те, що даний атлас - видання, проілюстроване лікарями (Френк Неттер був хірургом, Карлос Мачадо - кардіолог). Дане видання також містить рисунки, що ілюструють пренатальний та постнатальний кровообіг. 
Видання даного атласу 2020 року ВСВ «Медицина»; $\epsilon$ двомовним (англійська та українська).

Важливо при вивченні будови організму, зокрема, структур серцево-судинної системи, використання посібників з клінічної анатомії [11, $12,13,14,15,16,17,18,19,20]$.

У навчальному посібнику для студентів та лікарів-інтернів Г. Н.Топорова [13], присвяченому клінічній анатомії детально описано топографо-анатомічні особливості грудної області тіла людини. Відповідно Міжнародній анатомічній номенклатурі, представлені регіонарний та системний (органний) опис органів грудної порожнини, а також розглянутий їх анатомічний зв язок із сусідніми областями тіла людини (серце 3 великими судинами середостіння, легені, стравохід, клітковинні та спеціальні утворення) та судинно-нервовими структурами. Видання містить тлумачний словник 3 епонімами 3 клінічної анатомії, знайомство 3 яким може полегшити роботу зі спеціальною літературою у подальшій навчальній діяльності.

У атласі, створеному К. Мозесом зі співавторами [14], представлено численні ілюстрації високої якості, формат яких максимально наближений до реальності. Послідовне викладення чітко структурованого материалу, наочні рисунки, виділення кольором окремих структур дозволяють швидко знайти відповідь на конкретне питання та легко засвоїти інформацію. Цікавим та практичним є підхід до викладення анатомічних понять, який використовується у даному посібнику - від клінічного прикладу до анатомічних структур. Рентгенограми, КТ- та МРТ-зображення, які супроводжують кожну главу, дозволяють поповнити та розширити отриману інформацію.

Для зосередження на клінічно значущих аспектах будови та розвитку організму людини корисним $є$ англомовне видання «Netter's Clinical Anatomy» [15]. Ця книга Джона Хансена $\epsilon$ ідеальним довідником для студентів та лікарів. До ілюстрацій у стилі Неттера додано важливі дані 3 анатомії, гістології та ембріології, видання містить тематичні блоки, які пояснюють зв язок між структурою та функцією. У книзі присутні численні ілюстровані клінічні кореляції, які поєднують нормальну анатомію 3 клінічними станами. Електронна версія книги включає питання 3 декількома варіантами відповідей, тривимірні моделі, текст та зображення 3 можливістю пошуку. Наявні питання надають можливість самоконтролю для оцінки ступеню володіння матеріалом та виявлення матеріалу, який потребує подальшого вивчення.

У книзі «Анатомия сердечно-сосудистой системы» [16] 3 сучасних позицій викладена будова серцево-судинної системи. Особлива увага приділена ілюструванню анатомічної будови регіонарних артерій та вен, джерел кровопостачання та шляхів відтоку крові від органів, а також формування їхнього мікроциркуляторного русла.

«Клиническая анатомия сердца: иллюстрированный авторский цикл лекций» [17] містить базові відомості та сучасні дані щодо клінічної анатомії серця. Згідно думці автора, знання анатомії серця є одним з необхідних умов успішної професійної діяльності лікарів, які займаються оцінкою стану серця, діагностикою та лікуванням захворювань ССС. Перша лекція присвячена топографічній анатомії, наступна анатомічній будові серця. Провідна система та іннервація серця розглядаються у лекції 3, четверта лекція циклу містить інформацію щодо кровопостачання та лімфовідтоку органу. У лекції 5 мова йде про питання променевої анатомії: розглянуті рентгенівська, ультразвукова, комп `терно-томографічна та магнітнорезонансно-томографічна анатомія серця. Шоста лекція циклу стосується питань характеристик серця у дитячому віці. Анатомія та топографія серця новонародженого мають теоретичне та практичне значення для оцінки постнатального розвитку серця у дитячому віці. Відомості щодо характеристик будови та розташування серця здорового новонародженого $\epsilon$ анатомічною основою для діагностики вроджених аномалій. Питання шостої лекції циклу стосуються також особливостей дитячого серця на етапах постнатального розвитку. У лекції 7 обговорюється анатомо-ультразвукова характеристика вроджених вад серця, розглядаються основні етапи ембріогенезу серця, вади серця та судин та наголошується, що більшість вроджених вад характеризуються раннім формуванням на протязі другого місяця вагітності при порушенні ембріогенезу. Лекція 8 циклу присвячена питанням можливостей хірургічного лікування патології серця. 
Завершується цикл лекцій списком літератури 3 питань клінічної анатомії серця. Посібник призначений для лікарів різних медичних спеціальностей, але може бути винятково корисним студентам на початку вивчення будови та розвитку ССС. На основі друкованої версії посібника створене також електроне видання.

Наразі існує велика кількість книг та статей, присвячених техніці хірургічних втручань на серці. Це цілком виправдано, так як успіхи серцево-судинної хірургії безпосередньо залежать від хірургічної техніки. Однак немає сенсу очікувати від хірурга високої майстерності, якщо він не володіє знанням морфології. «Хирургическая анатомия сердца по Уилкоксу» Р. Г. Андерсона, Д. Е. Спайсера, Э. М. Хлавачека, Э. К. Кука, К. Л. Бейкера [18] містить опис специфічної анатомії нормально сформованих сердець i сердець із складними вродженими аномаліями. Знання 3 анатомії серця використовуються для оцінки та інтерпретації дефектів, пошкоджень, аномалій та розуміння сутності хірургічних втручань, необхідних для усунення тієї чи іншої проблеми. Різноманітний ілюстративний матеріал у вигляді кольорових рисунків та фотографій супроводжує всі анатомічні описи, та забезпечений просторовими орієнтирами. Книга містить комп'ютерні та магнітно-резонансними томограмами - 3 повною та точною прижиттєвою анатомією серця. Детальні описи тактики хірургічних втручань розглянуто у виданні «Хирургическая анатомия сердца по Уилкоксу» невід ємно від знань 3 анатомії та морфології серця, які лежать у основі майстерності кардіохірурга. Книга розрахована на широке коло спеціалістів 3 кардіології, але може бути використана не тільки як практичне керівництво, а і у якості підручника 3 анатомії серця для практикуючого лікаря, дослідника або студента-медика.

У навчальному посібнику під редакцією E. I. Борзяка «Анатомия человека. Фотографический атлас» [19], призначеному для студентів вищих медичних закладів, надані фотографії натуральних анатомічних препаратів. У виданні у візуальній формі викладені систематизовані відомості наукового та прикладного характеру з анатомії людини, які $є$ основою інформаційної культури майбутнього фахівця та сприяють становленню його практичної діяльності. Єдність візуального ряду атласу досягнуто послідовним доповненням скелету оточуючими його органами. Цей принцип у комбінації з дозованим збільшенням кількості нових анатомічних структур та термінів дозволяє легко засвоювати та швидко запам ятовувати представлений матеріал.

У 2 томі даного видання представлені дані щодо будови серцево-судинної та лімфатичної системи.

В основі «Анатомічного атласу людини» Фредеріка Мартіні [20] - восьме видання «Фундаментальної анатомії та фізіології». Ілюстрації в атласі розміщено за ділянками тіла, до складу ілюстрацій входять корозійні препарати судин, ангіограми аорти, легень, вінцевих артерій, лімфангіограми грудної клітки та малого тазу, артеріограми черевної порожнини. Видання містить текст на чотирьох мовах: українською, російською, англійською, латинською та призначене для студентів медичних закладів вищої освіти.

У навчальному процесі доцільним та корисним $\epsilon$ використання посібників, завдання яких сприяють розвитку у студентів яскравих та образних уявлень про будову організму, відповідають принципам формування явища ейдетизму (яке полягає в збереженні яскравого, наочного образу предмета тривалий час після зникнення його 3 поля зору) $[21,22,23,24]$. Посібники даного типу структуровані на розділи відповідно системам організму. Кожна сторінка містить формалізовані завдання: замалювати літерні та цифрові позначення на рисунках і в схемах різними (але відповідними) кольорами; заповнити таблиці відповідними анатомічними термінами, еквівалентами та необхідними даними. Використання атласів-розфарбовок [22, $23,24]$ при вивченні ССС допомагає краще запам'ятовувати анатомічну будову та взаємне розташування органів, a також деталі їх гістологічної будови. Реалістичні рисунки (в тому числі, тривимірні зображення та зображення мікроскопічної будови клітин і тканин) точно ілюструють структури тіла людини та їх взаємне розташування. Звертають на себе увагу зображення серця у різних проекціях, водночас в наявності схеми будови стінки серця та судин, які демонструють ї якісний (тканинний та клітинний) склад. Основні анатомічні та гістологічні терміни пов язані 3 візуальними ефектами: чіткі описові огляди кожної ілюстрації 
виділені жирним шрифтом, щоб полегшити можливість пов язати текстову та візуальну інформацію. Важливим плюсом навчальних видань даного типу є можливість самоперевірки. Кожна сторінка 3 ілюстраціями до теми містить завдання - пропонуються тести або заповнення пробілів в описі структури, вірні відповіді розміщені у нижній частини сторінки.

Цікавими та вельми корисними для використання у навчальному процесі $є$ видання у вигляді флеш-карток [25, 26]. Існує безліч варіантів навчальних посібників даного типу як у друкованому, так і в електронному форматі. Перше знайомство студентів 3 подібними навчальними посібниками відбувається у момент початку вивчення анатомії людини та гістології. У анатомічних флеш-картках [25] кольорові ілюстрації атласу анатомії Неттера поєднані 3 коротким текстом, який ідентифікує структури та надає відповідну анатомічну та клінічно значущу інформацію. Гістологічні картки [26] містять класичні ілюстрації та фото мікроскопічних препаратів для світлової та електронної мікроскопії. Короткі текстові резюме у флешкартках містять інформацію, яка надана з позицій клінічної значущості мікроскопічної будови та функції структур організму. Особливістю флешкарток $\epsilon$ наявність перехресних посилань на текст підручників та атласів, тому є можливим легко отримати більш детальну інформацію щодо будьякої теми (прикладом пов язаних між собою ресурсів можуть слугувати «Netter's Histology Flash Cards» [26] та«Netter's essential histology» [27]). Друковані видання являють собою набір флеш-карток у картонній коробці, що робить зручним їх зберігання. Спеціальне металеве кільце, яке входить до складу набору, та перфораційні отвори у картках дозволяють носити 3 собою обрані групи карток. Для студентів, які віддають перевагу роботі 3 технічними пристроями, існує електронна версія флеш-карток.

Щодо вивчення мікроскопічної будови ССС, для теоретичної підготовки існують підручники $[28,29,30]$ та велика кількість різноманітних видань 3 гістології - від атласів до монографій [31, $32,33,34,35,36,37]$. Ці видання добре структуровані та містять велику кількість ілюстрацій. Національний підручник «Гістологія. Цитологія. Ембріологія» за редакцією О. Д. Луцика та Ю. Б. Чайковського [28] створений із залученням широкого кола авторитетних фахівців - гістологів та ембріологів - 3 різних регіонів України 3 урахуванням найновішої редакції Міжнародної гістологічної термінології [31]. Виклад матеріалу гармонізовано $з$ типовою програмою нормативної навчальної дисципліни «Гістологія, цитологія, ембріологія», затвердженою МО3 України, 3 урахуванням кращих зарубіжних аналогів. Порівняно 3 попередніми виданнями у книзі представлені кольорові ілюстрації та мікрофотографії, переважна більшість яких $\epsilon$ оригінальними напрацюваннями видавництва та колективу українських морфологів. Крім того, книга збагачена прикладами практичного застосування знань із цитології, гістології та ембріології для глибшого розуміння патологічних процесів, якими може бути уражений організм людини. У кінці кожного розділу в ієрархічному порядку наведено список термінів, які студент повинен засвоїти та вміти використовувати у своій подальшій навчальній i практичній діяльності. Серед ілюстрацій вирізняються фотографії гістологічних зрізів для світлової мікроскопії, електронограми, рисунки 3 препаратів та схеми мікроскопічної будови структур організму людини, у тому числі, серцево-судинної системи. Атлас $є$ навчальним посібником для студентів медичних вищих навчальних закладів.

Атлас І. В. Алмазова та Л. С. Сутулова [32] вийшов 1978 року. Посібник був створений для допомоги студентам при вивченні мікроскопічних препаратів на практичних заняттях. Основою атласу слугують рисунки 3 мікроскопічних препаратів та електронограми. Розділ 1 містить ілюстрації з основ цитології; у розділі 2, присвяченому ембріології, головними $\epsilon$ рисунки та фотографії, які демонструють особливості розвитку зародка людини. У розділі 3 представлені мікроскопічна та ультрамікроскопічна будова тканин, розділ 4 спеціальна гістологія (мікроскопічна анатомія). У главі розділу 4 атласу, яка присвячена ССС, містяться зображення препаратів судин мікроциркуляторного русла («класичні» гемокапіляри, артеріоли та венули м'якої мозкової оболони), артерій, вен та лімфатичних судин різного калібру (поперечний зріз стінки аорти, забарвлений орсеїном; артеріальні та венозні судини у складі судинно-нервового 
пучка; імпрегнована сріблом пухка волокниста сполучна тканина, яка містить лімфатичні капіляри; зрізи стінки серця, забарвлені гематоксиліном-еозином та залізним гематоксиліном). Наявні також схеми будови еластичної строми аорти, електронні мікрофотографії судин та оболонок серця (зокрема, міокарда), схема розвитку серця на різних стадіях ембріогенезу (цитується ілюстрація з А. А.Заварзіна, схеми за Штралем, Гісом та Борном). Не дивлячись на достатній час, який пройшов від моменту виходу атласу з друку, використання цього ресурсу реалізує мету авторів - навчити студентів «читати» мікроскопічні препарати та розуміти будову морфологічних субстратів, які визначають властивості структур організму та їх функціональні характеристики.

Широко відомим серед студентів та викладачів медичних вищих навчальних закладів $\epsilon$ навчально-методичний комплекс, який, спираючись практично на одні й ті самі ілюстрації, пропонує студенту матеріал, викладений на декількох рівнях складності та інформативності. До складу комплексу входять підручник, «Атлас по гистологии, цитологии и эмбриологии» [33], лекції, тести та монографія «Молекулярная биология». Основою комплексу, у тому числі, атласу, слугують не рисунки, а оригінальні кольорові фото гістологічних препаратів для світлової мікроскопії. Серед ілюстрацій присутні також електронограми та схеми будови мікроскопічних структур. Слід відзначити, що на сучасному етапі розвиток технічної бази дозволяє створювати навчальні посібники з ілюстраціями, якість яких набагато вище, ніж якість фото гістологічних препаратів даного атласу. Але наявність послідовних та детальних підписів під ілюстраціями та інформаційних блоків щодо класифікацій та ембріональних джерел розвитку робить «Атлас по гистологии, цитологии и эмбриологии» С. Л. Кузнецова, Н. Н. Мушкамбарова та В. Л. Горячкіної практично незамінним при вивченні мікроскопічної будови структур організму. Також існує електронна версія, яка дозволяе використовувати даний ресурс навіть при відсутності достатньої кількості друкованих екземплярів у бібліотеці навчального закладу.

Основу атласу В. Л. Бикова та C. І. Юшканцевої [34] складають оригінальні рисунки з гістологічних препаратів по основним розділам стандартного курсу, які доповнені рядом рисунків 3 електронних мікрофотографій та схемами. Для зручності використання всі розділи атласу містять короткі систематизовані навчальні тексти, які надають пояснення до ілюстрацій та поглиблюють їх сприйняття, розкривають роль та значення окремих представлених структур. Автори рисунків та тексту - професіональні гістологи, які мають багаторічний досвід. Це видання призначене для студентів, але може бути корисним аспірантам, викладачам та лікарям різних спеціальностей у якості навчального посібника. Стосовно матеріалів щодо ССС, у цьому виданні звертають на себе увагу детальних ілюстрацій у розділах «Общая гистология» та «Частная гистология». Наявні рисунки 3 препаратів для світлової та електронної мікроскопії, які демонструють будову ендотелію та мезотелію, серцевої та гладкої м'язової тканини, стінки судин та серця. Дуже цінними $\epsilon$ зображення, які демонструють ультрамікроскопічну будову кардіоміоцитів різних типів та будову еластичних мембран стінки аорти - ці ілюстрації являють собою рисунки з електронних мікрофотографій. Атлас В. Л. Бикова та С. І. Юшканцевої є одним 3 незамінних ресурсів, які неодмінно слід використовувати при вивченні мікроскопічної будови структур організму, зокрема, органів CCC.

Гартнер та Хайатт [35] створили кольоровий атлас гістології, який видається багатьма мовами, широко відомий поєднанням художнього оформлення та клінічного підходу до викладення матеріалу, а у 2008 році вийшов 3 друку у видавництві «Логосфера». Даний посібник розкриває зв 'язки гістологічної інформації 3 основами медичної практики. Глава 8 атласу присвячена кровоносній системі та починається 3 введення, в якому надається коротка характеристика складових даної системи. Далі розміщена інформація щодо гістофізіології структур ССС, після чого у вигляді окремого невеликого блоку йде вставка щодо клінічних аспектів. Також у главі 8 надані короткі відомості про гістологічну організацію серця та судин та схеми: перша демонструє будову артерій та вен обидві судини розміщені на одній сторінці, тому зручно не тільки побачити порядок розташування структур у стінках артеріальних та венозних судин, а і визначити відмінності у їх будові; на 
другій схемі зображені типи капілярів. Обидві схеми та ілюстрації до теми (фото гістологічних зрізів та електронограми) супроводжують лаконічні зрозумілі підписи та пояснення щодо позначок структур на фото.

Фундаментальна монографія 3 гістології канадських авторів Хема та Кормака [36] вийшла у видавництві «Мир» у 5 томах 1982 року. Книга призначена для цитологів, гістологів, ембріологів, лікарів-патологоанатомів, викладачів, аспірантів та студентів університетів та від моменту виходу віднесена до класичних посібників. Не дивлячись на досить «поважний вік», на сучасному етапі книга не втратила своєї актуальності. У четвертому томі (1983), разом 3 іншими системами організму, розглянута серцевосудинна система. Видання містить дані щодо загального плану будови органів ССС, розглянуті відділи ССС та їх спеціальні функції. Надається інформація про мікроскопічну організацію структур серця та судин кровоносного та лімфатичного русла, яка демонструє зв язок будови та функції. Приділено увагу рецепторам CCC, обговорюється питання трансплантації кровоносних судин. Книга містить численні схеми та фото мікропрепаратів, $є$ також кольорові вставки. Одним 3 небагатьох недоліків даного видання $\epsilon$ те, що мікрофотографії препаратів для світлової мікроскопії надано у чорно-білому кольорі.

Видання «Гістологія, цитологія та ембріологія. Атлас: навчальний посібник» авторів О. Ю. Степаненко, О. В. Мірошниченко, Л. О. Зайченко та ін. [37] містить кольорові мікрофотографії програмних гістологічних препаратів, а також текстові коментарі до них, розкриває структурно-функціональну організацію органів і структур, що вивчаються. Цей атлас створений 3 метою забезпечити розуміння функціональної обумовленості будьякого структурного елемента. Усі терміни у виданні наведені відповідно до міжнародних гістологічної та ембріологічної номенклатури, посібник призначений для студентів медичних закладів вищої освіти, лікарів різних спеціальностей, а також біологів. Слід відзначити, що при вивченні базових дисциплін важливим $\epsilon$ використання англомовних підручників та атласів [38, 39, 40].

«Histology: A Text and Atlas: With Correlated Cell and Molecular Biology» [38] вважається одним
3 класичних посібників для медичних працівників та студентів. Видання поєднує текст та атлас, та, як і більшість сучасних видань 3 морфологічних дисциплін, містить велику кількість яскравих та інформативних ілюстрацій та фотографій. Ілюстрації розміщені після кожного розділу атласу i містять великогабаритні кольорові цифрові мікрофотографії 3 підписами, які висвітлюють деталі структури клітин, тканин та органів. Текст має зручний для читачів формат, що включає виділені червоним кольором ключові терміни, синій клінічний текст та папки, що охоплюють клінічні кореляції та функціональні характеристики. Розділи «101» надають студентам зручний для читача огляд важливої інформації, викладеної в попередніх розділах. До книги додається онлайн-атлас 3 інтерактивною функціональністю. Стосовно ССC, посібник містить розділ «Cardiovascular system», який побудований за класичною схемою. Спочатку розташована інформація про загальний план будови ССС, після неї йде частина тексту, присвячена серцю. Розміщені фото макропрепаратів, представлені схеми великого та малого кола кровообігу, схема будови стінки серця. Важливою $є$ наявність фото макроскопічних препаратів у різних ракурсах та у різному приближенні. Це дозволяє детально ознайомитись 3 анатомічними структурами перед тим, як вивчати їх мікроскопічну будову. У розділі «Cardiovascular system» наведені табличні дані щодо морфологічних характеристик стінок кровоносних судин та властивостей і функцій ендотеліальних клітин. Розділ містить дані щодо будови та функцій лімфатичних судин, а також приклади патологічних станів та характеристику змін судинної стінки та серця при атеросклерозі, гіпертонічній хворобі та ішемічній хворобі серця.

Junqueira's Basic Histology: Text and Atlas» [39] $\epsilon$ прикладом втілення морфофункціонального підходу до вивчення сучасної гістології: посібник насичений новітніми даними 3 області біохіміі, молекулярної біології, фізіології, імунології та інших дисциплін. Ці дані охоплюють різні галузі вивчення живого, створюючи комплексну уяву про описані об єкти та демонструючи, як клітини спеціалізувалися для виконання певних функцій. У кожній главі містяться підрозділи «Медичне значення», які висвітлюють безпосередній зв язок між основними гістологічними знаннями та патологією, клінічними ознаками хвороби та 
діагностикою. Загальний план, за яким побудований текст та розміщені ілюстрації у розділах посібника, можна назвати традиційним. Традиційними також $\epsilon$ лаконічність текстів кожного розділу у поєднанні з інформативністю та висока якість рисунків та фотографій препаратів. У всіх розділах $\epsilon$ заключний «Summary of key points» та «Assess your knowledge», який являє собою 10 тестових завдань типу «Множинний вибір».

У виданні «Атлас гістології» під редакцією Велша [40] представлений вичерпний гістологічний та цитологічний матеріал, необхідний для успішного навчання у медичних вищих навчальних закладах. Представлено більше, ніж 500 фотографій, отриманих при світловій та електронній мікроскопії, та схематичних зображень важливих гістологічних та цитологічних об`єктів та процесів. Серед ілюстрацій, які являють собою мікроскопічні препарати структур СCC, вирізняються препарати судин. Особливості будови стінки судин мікроциркуляторного русла, зокрема, гемокапілярів, демонструють електронограми ультратонких зрізів високої якості. Також звертають на себе увагу кольорові схеми будови кардіоміоцитів, основою яких є дані електронної мікроскопії. Атлас видавався німецькою, англійською та російською мовами, така велика кількість перевидань дала змогу авторам максимально покращити якість матеріалу, зробити його зручним та корисним як для молодих фахівців та студентів, так i для досвідчених морфологів.

Особливої уваги заслуговує навчальний посібник Радівоя Крстіча «Атлас микроскопической анатомии человека» [41], в якому представлені об ємні (стереоскопічні) тривимірні зображення мікроскопічної будови органів та систем організму людини. 3 позицій систематичної анатомії показані просторові взаємовідношення клітин та тканин у формуванні макроскопічних структур паренхіматозних та трубчастих органів, їх структурнофункціональних одиниць. За словами автора, цей атлас не $є$ підручником, а $є$ зібранням малюнків для полегшення розуміння мікроскопічної анатомії органів організму людини. Глава атласу «Серцево-судинна система» включає 14 таблиць. Ліворуч у кожній таблиці коротко викладені морфологічні дані щодо структур, будова яких ілюструється, та дані про функціональні характеристики цих структур. Також ліворуч практично у кожній таблиці розміщені фото мікроскопічних препаратів (гістологічних зрізів та електронограм) за темою таблиці. Праворуч у таблиці розміщено схематичні зображення, які демонструють тривимірну будову гістологічних структур серцево-судинної системи - стінки серця, клапанів серця, артерій різних морфологічних типів, судин мікроциркуляторного русла, вен та артеріовенулярних анастомозів.

Більшістю авторів до їх робіт внесені дані щодо джерел та етапів ембріогенезу серця та судин. Окремої уваги заслуговують видання «морфологічного напрямку», які містять детальну інформацію щодо внутрішньоутробного розвитку, зокрема структур ССС - у перекладі та і оригінальні [42, 43, 44].

Книга Moore K, Persaud T. V. N., Torchia M. «Before We Are Born» [42] друкується видавництвом «Elsevier» протягом багатьох років. Автори спрямовують це видання до уваги насамперед лікарів та студентів-медиків, тому що дане джерело є клінічно орієнтованим. У книзі надана інформація щодо ембріонального розвитку людини за періодами по тижнях, $\epsilon$ детально викладені відомості щодо ембріогенезу систем органів, також наведено приклади порушень внутрішньоутробного розвитку 3 обговоренням причин та проявів.

Щодо даних по CCC, «Before We Are Born» містить: численні кольорові схеми будови нормальних структур , які відповідають етапам їх розвитку; фото макропрепаратів органів ССC, у тому числі ті, які ілюструють аномалії внутрішньоутробного розвитку органів серцевосудинної системи; сонограми зародків на різних строках ембріогенезу.

Книга Томаса В. Садлера «Медична ембріологія за Лангманом» [43] являє собою переклад університетського підручника, 8 видання якого вийшло у США 2000 року. Книга сфокусована на клінічних аспектах ембріології, характеризує загальні закономірності ембріогенезу і становлення та розвиток органів і систем людського організму, плодових оболонок та плаценти. Серед ілюстрацій - тривимірні комп'ютерні схеми, електронні мікрофотографії, ультрасонограми, видання містить приклади клінічних спостережень. Детально розглянуті 
фактори розвитку, генетичні та молекулярні механізми, що контролюють ті чи інші події ембріогенезу. Кожний розділ завершується низкою клінічно орієнтованих проблем, розв'язання яких дозволяє об'єктивно перевірити якість засвоєння матеріалу. Книга розрахована на студентів та викладачів вищих медичних навчальних закладів, а також лікарів, що стикаються у повсякденній практиці 3 нормальним і патологічним ембріогенезом.

У навчальному посібнику «Медична ембріологія 3 основами тератології» [44] представлено матеріал 3 основ медичної ембріології, викладений відповідно до програми навчальної дисципліни "Гістологія, цитологія та ембріологія". Важливим у представленому посібнику є матеріал, який стосується принципів пренатального моніторингу розвитку дитини із зазначенням критеріїв його оцінки та строків скринінгових обстежень. Посібник насичений оригінальним ілюстративним матеріалом, частина якого представлена оригінальними фотографіями 3 архіву «Міжобласного центру медичної генетики імені П. М. Веропотвеляна» (м. Кривий Ріг), «Дніпропетровський спеціалізований клінічний медичний центр матері та дитини ім. проф. М. Ф. Руднєва», анатомічного музею кафедри анатомії людини Дніпропет $\neg$ ровської медичної академії MO3 України. Видання призначене для студентів медичних навчальних закладів III-IV рівнів акредитації, а також для викладачів, інтернів, сімейних лікарів, педіатрів, дитячих хірургів, акушерів-гінекологів, репродуктологів, генетиків, спеціалістів з пренатальної діагностики та інших.

Книгу, яка встановила сталий стандарт серед анатомічних текстів, створили у 1858 році Генрі Грей та Генрі Вандайк Картер для своїх колегхірургів. 41-ше видання "Gray's Anatomy: The Anatomical Basis of Clinical Practice» [45] містить інформацію щодо макро - та мікроскопічної будови органів та систем, ембріонального розвитку. Анатомічна інформація зіставляється 3 клінічною інформацією - у книзі викладені клінічні обговорення. Кожна глава редагована експертами відповідної області, що забезпечує доступ до найсучаснішої інформації за темою глави. У контенті сторінок, присвячених будові та розвитку ССС, є численні фото, включаючи велику колекцію рентгенівських, комп ютерних, магнітно-резонансних та гістологічних зображень. Важливою частиною контенту «Gray's Anatomy: The Anatomical Basis of Clinical Practice» $\epsilon$ матеріали глави 13, присвяченої ранньому ангіогенезу, та глави 52, у якій розглянутий ембріональний розвиток органів грудної порожнини. Серед численних ілюстрацій - велика кількість електронних мікрофотографій, які демонструють об ємні зображення сердець зародків на різних етапах внутрішньоутробного розвитку. Цікавими $є$ частини глав книги, які мають назву «Bonus e-book images and videos» та являють собою посилання на ресурси електронної версії видання (книга містить численні посилання на зовнішні джерела інформації, Expert Consult версія видання дозволяє знайти усі тексти, посилання та відео, і отримати до них доступ 3 різноманітних пристроїв).

Активне впровадження у практику охорони здоров`я сучасних медичних технологій та підвищення вимог до професійної компетентності лікарів визначають необхідність посилення практичного аспекту підготовки спеціалістів. У цьому контексті використання симуляційних технологій стає однією 3 найважливіших складових навчального процесу у медичному вищому навчальному закладі. Симуляційні центри стають невід ємною частиною процесу підвищення рівня професіних навичок студентів старших курсів, інтернів та лікарів. Симуляційний тренінг, зокрема, $\epsilon$ ефективним у напрацюванні та засвоєнні кардиохирургами навичок ендовідеохірургії. На початку вивчення будови ССС корисними є такі ресурси симуляційних центрів, як анатомічний сенсорний інтерактивний стіл зі спеціальним програмним забезпеченням та комплектом програм для встановлення на комп ютери [46]. Даний ресурс дозволяє з різних ракурсів вивчати системи та органи тіла людини у нормі та при патологічних станах, також надає змогу отримати інформацію щодо мікроскопічної будови структур організму.

Існують численні віртуальні платформи для вивчення анатомії та гістології, доступні для смартфонів, планшетів та стаціонарних комп'ютерів і спрямовані на вивчення цих складних дисциплін за новими методиками. Анатомічні атласи 3D - додатки, призначені для студентів-медиків, лікарів та інших фахівців медичного напрямку. «E-Anatomy» Antoine Micheau та Denis Hoa - інтерактивний атлас 
анатомії людини у зрізах та зображеннях, отриманих за допомогою методів медичної візуалізації [47]. Атлас містить також макроскопічну анатомію у ілюстраціях; зокрема, зображення, які демонструють будову органів CСС. У розділі «Грудна порожнина, живіт та таз» містяться дані щодо анатомії серця (ілюстрації, тривимірні зображення, фотографії розрізів). Також «е-Anatomy» демонструє будову судин різної локалізації за даними комп'ютерної томографії, магнітно-резонасної томографіі, рентгенографії. Матеріали атласу доступними на сайті, на Android та iOS.

Програми, призначені для навчальної демонстрації різних ланок ССС людини у нормі та при патології, створюючи об ємні зображення, дозволяють значно покращити наочність об 'єкта та наблизити його до реального біологічного прототипу. Область застосування даної та подібних до неї навчальних програм - медичні вищі навчальні заклади, курси спеціалізіції кардіологів та серцево-судинних хірургів [48].

Важливою властивістю віртуальних ресурсів 3 гістології $є$ можливість застосувати теоретичні знання на практиці, інтерпретувати мікроскопічну картину, видиму у полі зору мікроскопа [49, 50]. Ресурси віртуальних гістологічних лабораторій широко використовуються для вивчення будови органів на мікроскопічному та ультрамікроскопічному рівнях. На відомих навчальних віртуальних платформах пропонується до вивчення матеріал найвищої якості. Прикладом якісного віртуального ресурсу для закріплення теоретичного матеріалу та отримання практичних навичок щодо діагностики гістологічних препаратів $\epsilon$ histologyguide.com [49]. Ресурс має розділи: Введення, Slidebox (більше 280 препаратів для світлової мікроскопіï), Electron Microscopy (більше 180 електронограм), Вікторина (завдання для перевірки отриманих навичок 3 діагностування препаратів). Частини 9 Slidebox и Electron Microscopy містять препарати структур ССС - зрізи стінки серця, клапани серця та вен, артеріальні та венозні судини, судини мікроциркуляторного русла (у тому числі, капіляри різних типів) - фото препаратів для світлової мікроскопії та електронні мікрофотографії відповідно. Ресурс histologyguide.com дозволяє детально вивчити різні ділянки мікроскопічних структур на різних збільшеннях, схему навігації по препарату та збільшення студент може обирати та змінювати за своїм бажанням. Таким чином, студент має можливість повторення теорії (стислі дані щодо об'єктів вивчення містить сторінка електронного ресурсу, кожний препарат має детальний опис), відпрацювання практичних навичок та роботи 3 гістологічною термінологічною базою англійською мовою.

«Atlas of Human Histology» авторів Robert L. Sorenson та T. Clark Brelje забезпечує друковану версію основних слайдів 3 даного сайта. Окремі слайди представлено у вигляді серії зображень зі збільшенням, яке поступово зростає, що допомагає передати відчуття масштабу та пропорції. Розробники ресурсу, які $є$ авторами атласу, наголошують, що матеріали сайту та атласу призначені для використання у поєднанні 3 якісним підручником, а не замість нього.

Pecypc Biolucida [50] для виртуальної мікроскопії надає викладачам та студентам платформу для сумісної праці. Динамічний та насичений контент $\epsilon$ доступним одночасно великій кількості користувачів. Існує можливість налаштування організації слайдів для впорядкування зображень для лекцій та матеріалів курсу та включення додаткових матеріалів (посилань на веб-сайти, відео і т.ін.). Biolucida дозволяє студентам передивлятися слайди на повному спектрі комп'ютерних пристроїв, включаючи ПК, Мас, телефони та планшети Apple и Android. Віртуальний мікроскоп $\epsilon$ особливо важливим за умов відсутності можливості відпрацювання практичних навичок у навчальному класі у період карантину внаслідок пандемії.

Висновки. Необхідною умовою розуміння сутності морфологічних змін при патологічних процесах є знання нормальної будови та розвитку структур серцево-судинної системи. Звертає на себе увагу клінічна орієнтованість переважної більшості сучасних посібників 3 дисциплін «Анатомія людини» і «Гістологія, цитологія та ембріологія». Для отримання якісної теоретичної підготовки при вивченні розвитку та будови структур серцево-судинної системи, важливим $€$ використання саме клінічно орієнтованих навчальних видань. При розробці нових навчальних матеріалів перспективним $є$ внесення до їх складу даних щодо сучасних клінічних та 
експериментальних досліджень серцево-судинної системи.

\section{Список літератури}

1. Mendis S, Puska P, Norrving B, редакторы. Всемирный атлас профилактики сердечно-сосудистых заболеваний и борьбы с ними. Женева: Всемирная организация здравоохранения; 2013. Режим доступа: https://www.who.int/cardiovascular_diseases/publications/a tlas_cvd/ru/.

2. Hoffman JI, Kaplan S. The incidence of congenital heart disease. J Am Coll Cardiol. 2002. 39(12). 1890-1900. DOI: 10.1016/s0735-1097(02)01886-7.

3. Bruneau BG. The developmental genetics of congenital heart disease. Nature. 2008. 451(7181). 943-948. DOI: 10.1038/nature06801.

4. Візір ВА, Буряк ВB, Заіка IB. Сучасний стан підготовки лікаря-кардіолога: проблеми та перспективи. Молодий вчений. 2016. № 11(38). 423-425.

5. Лазоришинець ВВ. Світові тенденції в українській кардіохірургії. Український журнал серцево-судинної хірургії. 2019. 8-9.

6. Данильченко ЛІ. Наукове обгрунтування пріоритетних напрямків розвитку медичної допомоги кардіологічним хворим в умовах міста. Світ медицини та біології. 2017. № 2(60). 34-39.

7. Шерстюк CO, Наконечна СА. Робоча навчальна програма дисципліни «Анатомія людини». Харківський національний університет імені В.Н. Каразіна; 2020. Режим доступу: http://medicine.karazin.ua/studentlife/normativni-dokumenti-scho-reglamentuyut-navchalniyprotses

8. Проценко ОС, Падалко ВI, Шаповал ОВ. Робоча навчальна програма дисципліни «Гістологія, цитологія та ембріологія». Харківський національний університет імені В.Н. Каразіна; 2020. Режим доступу: http://medicine.karazin.ua/student-life/normativni-

dokumenti-scho-reglamentuyut-navchalniy-protses

9. Синельников РД. Атлас анатомии человека. М.: Медицина; 1979. 233-463.

10. Неттер ФГ. Atlas of Human Anatomy=Атлас анатомії людини: переклад 7-го англ. вид.: двомовне вид. К.: ВСВ «Медицина»; 2020. 736 с.

11. Островерхов ГЕ, редактор. Оперативная хирургия и топографическая анатомия. М.: «МИА», 2013. 736 с. 426-435.

12. Кованов ВВ. Оперативная хирургия и топографическая анатомия. М.: Медицина; 2001. 408 с. 129-151.

13. Топоров ГН. Клиническая анатомия груди: учебное пособие для студентов и врачей-интернов. Коллегиум; $2007.584 \mathrm{c}$

14. Мозес КП, Бэнкс ДжК, Нава ПБ, Петерсен Д. Атлас клинической анатомии. М.: ООО «Рид Элсивер»; 2010. $712 \mathrm{c}$.

15. Hansen JT. Netter's Clinical Anatomy,4th edition. Boston: Elsevier; 2018. 630 p.

16. Козлов ВИ. Анатомия сердечно-сосудистой системы. Практическая медицина; 2017. 192 с.
17. Каган ИИ. Клиническая анатомия сердца: иллюстрированный авторский цикл лекций. М.: ГЭОТАР-Медиа; 2018. 128 с.

18. Андерсон РГ, Спайсер ДЕ, Хлавачек ЭМ, Кук ЭК, Бейкер КЛ. Хирургическая анатомия сердца по Уилкоксу. М.: Логосфера; 2015. 456 с.

19. Борзяк ЭИ, Хагенс Г, Путалова ИН. Анатомия человека. Фотографический атлас. Учебное пособие в 3-х томах. Том 2. Сердечно-сосудистая система. Лимфатическая система. М.: ГЭОТАР-Медиа; 2015. 368 с. 20. Мартіні Ф. Анатомічний атлас людини (IV p. а.), 3-є видання, чотиримовне. К.: ВСВ «Медицина»; 2018. 128 с.

21. Черкасов ВГ, Дзевульська IB, Ковальчук ОI. Анатомія людини (контроль за самостійною підготовкою до практичних занять). Книга Плюс; 2019. $124 \mathrm{c}$.

22. Хансен ДжТ. Анатомия Неттера: атлас-раскраска. М: Эксмо; 2019. 416 с.

23. Капіт У, Елсон ЛМ. Анатомія. Книга-розфарбовка. К.: ВСВ «Медицина»; 2011. 184 с.

24. McCann S, Wise E. Anatomy Coloring Book. Kaplan Publishing; 2008. 331 p.

25. Hansen JT. Netter's Anatomy Flash Cards: with Online Student Consult Access (Netter Basic Science), 4th Edition. Elsevier; 2014. 674 p.

26. Ovalle WK, Nahirney PC. Netter's Histology Flash Cards. Elsevier; 2016, 467 p.

27. Ovalle WK, Nahirney PC. Netter's Essential Histology: with Online Student Consult Access (Netter Basic Science), 2th Edition. Saunders; 2013, 536 p.

28. Луцик ОД, Чайковський ЮБ, редактори. Гістологія. Цитологія. Ембріологія: підручник. Вінниця: Нова Книга; 2018. 592 с.

29. Афанасьев ЮИ, Кузнецов СЛ, Юрина НА, редакторы. Гистология, цитология и эмбриология: учебник для мед. вузов. Изд-е 6-е, перераб. и доп. М.: Медицина; 2006. 766 с.

30. Улумбеков ЭГ, Челышев ЮА, редакторы. Гистология, эмбриология, цитология: учебник. М.: ГЭОТАР-Медиа; 2009. 407 с.

31. Луцик ОД, Чайковський ЮБ, редактори. Terminologia Histologica. International Terms for Human Cytology and Histology = Гістологічна термінологія. Міжнародні терміни $з$ цитології та гістології людини: навчальний посібник (BН3 I-IV p. а.). К.: ВCВ «Медицина»; 2010. 305 с.

32. Алмазов ИВ, Сутулов ЛС. Атлас по гистологии, цитологии эмбриологии. М.: Медицина; 1978. 544 с.

33. Кузнецов СЛ, Мушкамбаров НН, Горячкина ВЛ. Атлас по гистологии, цитологии эмбриологии. М.: МИА; 2010. 376 с.

34. Быков ВЛ, Юшканцева СИ. Гистология, цитология, эмбриология: атлас: учебное пособие. М.: ГЭОТАРМедиа; 2012. 296 с.

35. Гартнер ЛП. Хайатт ДжЛ. Цветной атлас гистологии. М.: Логосфера; 2008. 480 с.

36. Хэм А, Кормак Д. Гистология. М.: Мир; 1983. Т.4. 647.

37. Степаненко ОЮ, Мірошниченко ОВ, Зайченко ЛО та iн. Гістологія, цитологія та ембріологія. Атлас: навчальний посібник. ВСВ «Медицина»; 2017. 152 с. 
38. Ross MH. Histology: A Text and Atlas: With Correlated Cell and Molecular Biology. Lippincott Wiliams \& Wilkins; 2006. 996 p.

39. Mescher AL. Junqueira's Basic Histology: Text and Atlas, 15th edition. McGraw-Hill Education / Medical; 2018. $576 \mathrm{p}$.

40. Велш У., редактор. Атлас гистологии. М.: ГЭОТАРМедиа; 2011. 264 с.

41. Крстич Р. Атлас микроскопической анатомии человека: учебное пособие. М.: Мир и образование; 2016. 608 c.

42. Moore K, Persaud TVN, Torchia M. Before we are born. Esevier; 2016. 384 p. 189-224.

43. Садлер ТВ. Медична ембріологія за Лангманом. Львів: Наутілус; 2001. 550 с.

44. Сілкіна ЮВ, Веропотвелян МП, Данкович НО. Медична ембріологія 3 основами тератології: навчальний посібник. Нова книга; 2019. 206 с.

45. Standring S, editor. Gray's Anatomy: The anatomical basis of clinical practice; 41st Ed. Elsevier; 2015. 1584 p. 127-139, 905-924.

46. Офіційний сайт медичного факультету Харківського національного університету імені В. Н. Каразіна. Режим доступу: https: http://medicine.karazin.ua/

47. Мишо А, Хоа Д. Е-Anatomy. Раздел Грудная клетка, живот и таз. Режим доступа: https://www.imaios.com/ru/e-Anatomy/Grudnaya-kletkazhivot-i-taz/Serdce-illyustracii DOI

https://doi.org/10.37019/e-anatomy/180.ru

48. Соколова ИО, Беляков ДА. 3D Атлас анатомии и физиологии сердечно-сосудистой системы человека в норме и патологии, 2019. Режим доступу: https://www.elibrary.ru/item.asp?id=39345690

49. Sorenson RL, Brelje TC. Atlas of human histology: a guide to microscopic structure of cells, tissues and organs; 3rd edition. Available from: http://www.histologyguide.com 50. Biolucida ${ }^{\circledR}$ for Medical Education. Available from: https://www.mbfbioscience.com/biolucida-medicaleducation/

\section{References}

1. Mendis, S, Puska, P, Norrving, B, editors (2013). World atlas on cardiovascular disease prevention and control. Geneva: World Health Organization; 2013. Available from: https://www.who.int/cardiovascular_diseases/publications/a tlas_cvd/ru/.

2. Hoffman, JI, Kaplan, S (2002). The incidence of congenital heart disease. J Am Coll Cardiol. 39(12). 18901900. DOI: 10.1016/s0735-1097(02)01886-7.

3. Bruneau, BG. The developmental genetics of congenital heart disease. Nature. 2008. 451(7181). 943-948. DOI: 10.1038/nature06801.

4. Vizir, VA, Buriak, VV, Zaika, IV (2016). Current status of cardiologist training: problems and perspectives. Young Scientist. \# 11(38). 423-425. [in Ukranian]

5. Lazoryshynets, VV (2019). World tendencies in Ukrainian cardiac surgery. Ukrainian Journal of Cardiovascular Surgery. 8-9. [in Ukranian]

6. Danilchenko, LI (2017). Scientific substantiation of priority directions of development of medical care for cardiac patients in urban conditions. The world of medicine and biology. \# 2(60). 34-39. [in Ukranian]
7. Sherstyuk, SO, Nakonechna, SA (2020). Working curriculum of the academic discipline "Human Anatomy". V. N. Karazin Kharkiv National University. Available from: http://medicine.karazin.ua/student-life/normativnidokumenti-scho-reglamentuyut-navchalniy-protses 8. Protsenko, OS, Padalko, VI, Shapoval, OV (2020). Working curriculum of the academic discipline "Histology, cytology and embryology". V. N. Karazin Kharkiv National University. Available from: http://medicine.karazin.ua/student-life/normativnidokumenti-scho-reglamentuyut-navchalniy-protses

9. Sinelnikov, RD (1979). Atlas of human anatomy. Moscow: Publishing House "Medicine". 233-463. [in Russian]

10. Netter, FG (2020). Atlas of Human Anatomy: translation of the 7th Eng. ed.: bilingual ed. Kiev: Publishing House "Medicine". $736 \mathrm{p}$.

11. Ostroverkhov, GE, editor (2013). Operative surgery and topographic anatomy. Moscow: "MIA". 736 p. 426-435. [in Russian]

12. Kovanov, VV (2001). Operative surgery and topographic anatomy. Moscow: Publishing House "Medicine". 408 p. 129-151. [in Russian]

13. Toporov, GN (2007). Clinical anatomy of thorax: study guide for students and interns. Collegium. 584 p. [in Russian]

14. Moses, KP, Banks, JK, Nava, PB, Petersen, D (2010). Atlas of Clinical Anatomy. Moscow: Reed Elsevier limited liability company. 712 p. [in Russian]

15. Hansen, JT (2018). Netter's Clinical Anatomy,4th edition. Boston: Elsevier. 630 p.

16. Kozlov, VI (2017). Anatomy of the cardiovascular system. Practical medicine. 192 p. [in Russian]

17. Kagan, AI (2018). Clinical anatomy of the heart: illustrated author's series of lectures. Moscow: GEOTARMedia. 128 p. [in Russian]

18. Anderson, RG, Spicer, DE, Hlavachek, EM, Cook, EK, Baker, KL (2015). Wilcox Surgical Anatomy of the Heart. Moscow: Logosphere. 456 p.

19. Borzyak, EI, Hagens, G, Putalova, IN (2015). Human anatomy. Photographic atlas. Study guide in 3 volumes. Vol. 2. Cardiovascular system. Lymphatic system. Moscow: GEOTAR-Media. 368 p. [in Russian]

20. Martini, F (2018). Atlas of Human Anatomy (IV accredit. level), 3rd edition, four-language. Kiev: Publishing House "Medicine". 128 p. [in Ukranian]

21. Cherkasov, VG, Dzevulska, IV, Kovalchuk, OI (2019). Human anatomy (control of independent preparation for practical classes). Publishing House "Book Plus". 124 p. [in Ukranian]

22. Hansen, JT (2019). Netter's Anatomy: Coloring Atlas. Moscow: Eksmo. 416 p. [in Russian]

23. Kapit,W, Elson, LM (2011). Anatomy. Coloring book. Kiev: Publishing House "Medicine". 184 p. [in Ukranian]

24. McCann, S, Wise E (2008). Anatomy Coloring Book. Kaplan Publishing. 331 p.

25. Hansen, JT (2014). Netter's Anatomy Flash Cards: with Online Student Consult Access (Netter Basic Science), 4th Edition. Elsevier. 674 p.

26. Ovalle, WK, Nahirney, PC (2016). Netter's Histology Flash Cards. Elsevier, 467 p. 
27. Ovalle WK, Nahirney PC. Netter's Essential Histology: with Online Student Consult Access (Netter Basic Science), 2th Edition. Saunders; 2013, 536 p.

28. Lutsyk, OD, Tchaikovsky, YuB, editors (2018). Histology. Cytology. Embryology: textbook. Vinnytsia: Publishing House "New Book". 592 p. [in Ukranian]

29. Afanasyev, YI, Kuznetsov, SL, Yurina, NA, editors (2006). Histology, cytology and embryology: textbook for medical universities. 6th ed., revised and add. Moscow: Publishing House "Medicine". 766 p. [in Russian]

30. Ulumbekov, EG, Chelyshev, YA, editors (2009). Histology, embryology, cytology: textbook. Moscow: GEOTAR-Media. 407 p. [in Russian]

31. Lutsyk, OD, Tchaikovsky, YuB, editors (2010). Terminologia Histologica. International Terms for Human Cytology and Histology. Kiev: Publishing House "Medicine". 305 p. [in Ukranian]

32. Almazov, IV, Sutulov, LS (1978). Atlas of Histology, Cytology, Embryology. Moscow: Publishing House "Medicine". 544 p. [in Russian]

33. Kuznetsov, SL, Mushkambarov, NN, Goryachkina, VL (2010). Atlas of Histology, Cytology, Embryology. Moscow: Publishing House "MIA". 376 p. [in Russian]

34. Bykov, VL, Yushkantseva, SI (2012). Histology, cytology, embryology: Atlas: Tutorial. Moscow: GEOTARMedia. 296 p. [in Russian]

35. Gartner, LP. Hiatt, JL (2008). Color atlas of histology. Moscow: Logosphere. 480 p. [in Russian]

36. Ham, A, Cormac, D (1983). Histology. Moscow: Mir Publishers. Vol.4. 6-47. [in Russian]

37. Stepanenko, OY, Miroshnychenko, OV, Zaichenko, LO et al. (2017). Histology, cytology and embryology. Atlas: Tutorial. Kiev: Publishing House "Medicine". 152 p. [in Ukranian]

38. Ross, MH (2006). Histology: A Text and Atlas: With Correlated Cell and Molecular Biology. Lippincott Wiliams \& Wilkins. 996 p.
39. Mescher, AL (2018). Junqueira's Basic Histology: Text and Atlas, 15th edition. McGraw-Hill Education / Medical. $576 \mathrm{p}$.

40. Welsh, W., editor (2011). Atlas of Histology. Moscow: GEOTAR-Media. 264 p. [in Russian]

41. Krstic, R (2016). Atlas of human microscopic anatomy. Moscow: World and Education. 608 p. [in Russian]

42. Moore, K, Persaud, TVN, Torchia, M (2016). Before we are born. Esevier. 384 p. 189-224.

43. Sadler, TV (2001). Medical education according to Langman. Lviv: Nautilus. 550 p. [in Ukranian]

44. Silkina, YuV, Veropotvelyan, MP, Dankovich, NO (2019). Medical education with the basics of teratology: study guide. Publishing House "New book". 206 p. [in Ukranian]

45. Standring, S, editor (2015). Gray's Anatomy: The anatomical basis of clinical practice; 41st Ed. Elsevier. 1584 p. 127-139, 905-924.

46. Official website of the School of Medicine, V. N. Karazin Kharkiv National University. Available from: https: http://medicine.karazin.ua/

47. Michaud, A, Hoa, D. E-Anatomy. Chest, abdomen and pelvis. Available from: https://www.imaios.com/ru/eAnatomy/Grudnaya-kletka-zhivot-i-taz/Serdce-illyustracii DOI https://doi.org/10.37019/e-anatomy/180.ru

48. Sokolova, IO, Belyakov, DA (2019). 3D Atlas of anatomy and physiology of the human cardiovascular system in normal and pathological conditions. Available from: https://www.elibrary.ru/item.asp?id=39345690 [in Russian] 49. Sorenson, RL, Brelje, TC. Atlas of human histology: a guide to microscopic structure of cells, tissues and organs; 3rd edition. Available from: http://www.histologyguide.com 50. Biolucida ${ }^{\circledR}$ for Medical Education. Available from: https://www.mbfbioscience.com/biolucida-medicaleducation/

\title{
DEVELOPMENT AND ORGANIZATION OF THE CARDIOVASCULAR SYSTEM STRUCTURES: THEORETICAL AND PRACTICAL ASPECTS OF THE STUDY (PART 1)
}

\author{
Protsenko Olena, Shapoval Olena, Teslenko Anna, Vorona Dariya
}

Mail for correspondence: shapoval@karazin.ua

Summary. The article highlights the theoretical and practical aspects of studying the development and structure of the cardiovascular system (CVS). Cardiovascular diseases are characterized by a high prevalence and mortality, so the provision of high-quality and timely cardiac care to the population is one of the important tasks of the health care system. A necessary prerequisite for understanding the essence of morphological changes in pathological processes is knowledge of the normal structure and development of CVS structures. The aim of the work was to determine the theoretical and practical aspects of studying the development and structure of CVS structures, which was performed by review of literature sources (part 1 of the article is devoted to theoretical aspects, and part 2 discusses the practical aspects). Publications on human anatomy, histology, cytology and embryology, which are traditionally used in the study of the development and structure of the human body, in particular, CVS organs, have been analyzed. The sets of illustrations of modern publications, in addition to photos of wet gross specimens, corrosion preparations and X-ray radiographs, contain angiograms, in particular, lymphangiograms and arteriograms. The use of color atlases in the study of CVS allows to remember the anatomical structure and relative position of organs, as well as details of their histological structure. It is effective to use anatomical and histological flash cards, which contain color illustrations in combination with short text that identifies the structures and contains relevant information and clinical correlations, in the process of CVS 
study. The illustrations include photographs of histological sections for light microscopy, electronograms, drawings of preparations, and diagrams of the microscopic structure of CVS structures. Most educational publications in the disciplines "Human Anatomy" and "Histology, Cytology and Embryology" include data on the sources and stages of embryogenesis of the heart and blood vessels. There are also special editions on human embryology with up-to-date data on CVS embryogenesis. The importance of using editions which are manuals for the practical activities of specialists in the field of cardiology and cardiac surgery is determined. All modern editions contain large collections of $X$-ray, computer, magnetic resonance and histological images. The resources of simulation centers are useful, in particular, touch interactive anatomical tables with special software and anatomical 3D atlases. Software programs designed for educational demonstration of various parts of human CVS under normal and pathological conditions are available for smartphones, tablet PCs and desktop computers. An important feature of virtual resources in histology is their interactivity and the ability to apply theoretical knowledge in practice. Available platforms have dynamic and rich content for the teacher to work with a large number of students simultaneously. Many of the analyzed manuals contain numerous links to external sources of information, online versions of publications, which allows to gain access all texts, links and videos from various devices. Therefore, it is important to use clinically oriented educational publications to obtain high quality theoretical training in the study of the development and structure of the heart and vessels. When developing new educational materials, it is promising to include clinical and experimental data on CVS to them.

Key words: cardiovascular system, embryogenesis, macroscopic structure, microscopic structure, theoretical aspects

Information about author

Protsenko Olena, DM, PhD, Full Prof.,

Head of Department of General and Clinical Pathology, School of Medicine V. N. Karazin Kharkiv National University, School of Medicine, 6 Svobody Sq., 61022, Kharkiv, Ukraine

e-mail: protcenko@karazin.ua https://orcid.org/0000-0001-6998-9783
Shapoval Olena, MD, PhD, Assoc. Prof., Department of General and Clinical Pathology, School of Medicine, V. N. Karazin Kharkiv National University, Kharkiv, 6, Svobody Sq., 61022, Kharkiv, Ukraine e-mail: shapoval@karazin.ua https://orcid.org/0000-0002-8507-9197 Teslenko Anna, 4nd year student (ВИ-407), School of Medicine, V. N. Karazin Kharkiv
National University, School of Medicine, 6, Svobody Sq., 61022, Kharkiv, Ukraine e-mail: teslenkoan7@gmail.com Vorona Dariya, 4rd year student (ВИ-405), School of Medicine, V. N. Karazin Kharkiv National University, Kharkiv, 6, Svobody Sq., 61022, Kharkiv, Ukraine e-mail: vorona.dariya05@gmail.com

\title{
РАЗВИТИЕ И СТРОЕНИЕ СТРУКТУР СЕРДЕЧНО-СОСУДИСТОЙ СИСТЕМЫ: ТЕОРЕТИЧЕСКИЕ И ПРАКТИЧЕСКИЕ АСПЕКТЫ ИЗУЧЕНИЯ (ЧАСТЬ 1)
}

\author{
Проиенко О. С., Шаповал О. В., Тесленко А. А., Ворона Д. А.
}

Почта для переписки: shapoval@karazin.ua

\begin{abstract}
Резюме. В статье освещеены теоретические и практические аспекты изучения развития и строенеия сердечно-сосудистой системы (ССС). Болезни сердца и сосудов характеризуются высокой частотой и смертностью, поэтому оказание качественной и своевременной кардиологической помощи населению является одной из важнейших задач системы здравоохранения. Необходимым условием понимания сути морфологических изменений при патологических процессах является знание нормального строения и развития структур ССС. Целью работы было определение теоретических и практических аспектов изучения развития и строения структур ССС, что было проведено путем анализа источников литературы (часть 1 статьи посвящена теоретическим аспектам, часть 2 - практическим). Проанализированы печатные издания и другие источники информачии по анатомии, гистологии, цитологии и эмбриологии, которые используются при изучении развития и строения организма человека, в частности, органов ССС. Кроме классических источников, проанализирован ряд современных учебных пособий, в том числе, анатомические и гистологические флеш-карты, атласы-раскраски, анатомические 3D-атласы, Web-ресурсы. Эмбриогенез сердиа и сосудов рассмотрен в большинстве учебных изданий по анатомии и гистологии, существуют также современные специальные издания по эмбриологии человека. Определена важность использования ресурсов, которые являются пособиями для практической деятельности специалистов в области кардиологии и кардиохирургии. Все современные издания содержат множество данных по рентгеновским, компъютерным, магнитно-резонансныли, микроскопическим исследованиям ССС. Полезными являются ресурсы симуляционных иентров, 6 частности, анатомические сенсорные интерактивные столы со специальным программным обеспечением. Программы, предназначеные для учебной демонстрации разных отделов ССС человека в норме и при патологии, являются доступными для смартфонов, планшетов и стационарных компъютеров. Определено, что для получения качественной теоретической подготовки при изучении
\end{abstract}


развития и строения сердца и сосудов, важным является использование клинически ориентированных учебных изданий. При разработке учебных материалов следует вносить в состав новых пособий данные современных клинических и экспериментальных исследований ССС.

Ключевые слова: сердечно-сосудистая система, эмбриогенез, макроскопическое строение, микроскопическое строение, теоретические аспекты

\section{Информация об авторах}

Проиенко Елена Сергеевна, д. мед. н., проф., зав. кафедры общей и клинической патологии медицинского факультета Харьковский национальный университет имени В. Н. Каразина, медицинский факультет, пл. Свободы, 6 , Харьков, Украина, 61022

e-mail: protcenko@karazin.ua

https://orcid.org/0000-0001-6998-9783

Шаповал Елена Владимировна,

к. мед. н., доц. кафедры общей и клинической патологии медицинского факультета Харьковский национальный университет имени В. Н. Каразина, медицинский факультет, пл. Свободы, 6,

Харьков, Украина, 61022

e-mail: shapoval@karazin.ua

https://orcid.org/0000-0002-8507-9197

тесленко Анна Александровна,

студентка 4 курса (група ВИ-407)

медицинского факультета Харьковский национальный университет имени
В. Н. Каразина, медицинский факультет, пл. Свободы, 6, Харьков, Украина, 61022 e-mail: teslenkoan7@gmail.com

Ворона Дария Анатолиевна, студентка 4 курса (группа ВИ-405), медицинского факультета Харьковский национальный университет имени В. Н. Каразина, медицинский факультет, пл. Свободы, 6, Харьков, Украина, 61022 e-mail: vorona.dariya05@gmail.com

Conflicts of interest: author has no conflict of interest to declare.

Конфлікт інтересів: відсутній.

Конфликт интересов: отсутствует. 
Наукове електроне видання

\title{
АКТУАЛЬНІ ПРОБЛЕМИ СУЧАСНОЇ МЕДИЦИНИ
}

\author{
Випуск 6
}

Українською, англійською і російською мовами

Відповідальний за випуск: Матвєєнко М. С.

Комп`ютерне верстання: Голубнича Г. I.

Технічний редактор: Голубнича Г. I.

61022, Україна, м. Харків, майдан Свободи, 6.

Харківський національний університет імені В. Н. Каразіна 